DOE/RL-2000-76

Revision 0

\title{
Environmental Management Performance Report December 2000
}

Date Published

December 2000

Prepared for the U.S. Department of Energy

Assistant Secretary for Environmental Management

Project Hanford Management Contractor for the

U.S. Department of Energy under Contract DE-ACOe-60RL13200

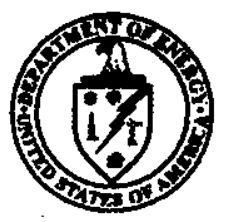

\section{United States}

Department of Energy

P.O. Box 550

Richlend, Woshington 99352

$\frac{\text { Chis Stallexighand }}{\text { Release Approval }} \frac{12-19-00}{\text { Date }}$ 


\section{LECAL DIBCLAMMER}

This report was prepared as an sccount of work sponsored by an agency of the Uniked States Government. Nelther the

Uniled States Government nor any agency thereof, nor any of thair employees, nor any of thair contractors, subcontractors or their employees, makes any warranty, expreses or Implied, or aceumes any logal liability or reaponsibility for the sccurecy, completeneas, or any third party's use or the results of such use of any information, apparatus, product, of process

disclosed, or represents that ths use would not infringe privately owned rights. Reference herein to any specific commercial product, process, or service by trade name, trademark, manufacturer, or otherwise, does not necessarily constitute or imply its endorsement, recommendation, or favoring by the United States Government or any agency thereof or the contractors or subcontractors. The views and opinions of authors expresesd herein do not necessarlly state or reflect those of the United States Government or any agency thereof.

Thls report hes been reproduced from the beet avallable copy. 


\section{INTRODUCTION}

The purpose of the Environmental Management Performance Report (EMPR) is to provide the Department of Energy Richland Operations Office's (DOE-RL's) report of Hanford's Environmental Management (EM) performance by:

- Project Hanford Management Contract (PHMC) through Fluor Hanford, Inc. (FH) and its subcontractors,

- Environmental Restoration Contract through Bechtel Hanford, Inc. (BHI), and its subcontractors, and

- Pacific Northwest National Laboratories (PNNL) for Science and Technology support to the EM Mission.

The Office of Safety Regulation of the TWRS Privatization Contractor's reporting responsibilities have been transferred to the Office of River Protection; consequently, a separate report is no longer produced.

This report is a monthly publication that summarizes EM Site performance under RL Operations Office. It is organized by the three sections listed above, with each section containing an Executive Summary and Area Performance Summaries. A glossary of terms is provided at the end of this report for reference purposes.

The report date on the cover reflects the month in which the report is released. 
꽆ำ 


\section{Project Hanford Management Contractor Environmental Management Performance Report to DOE Richland Operations Office December 2000}

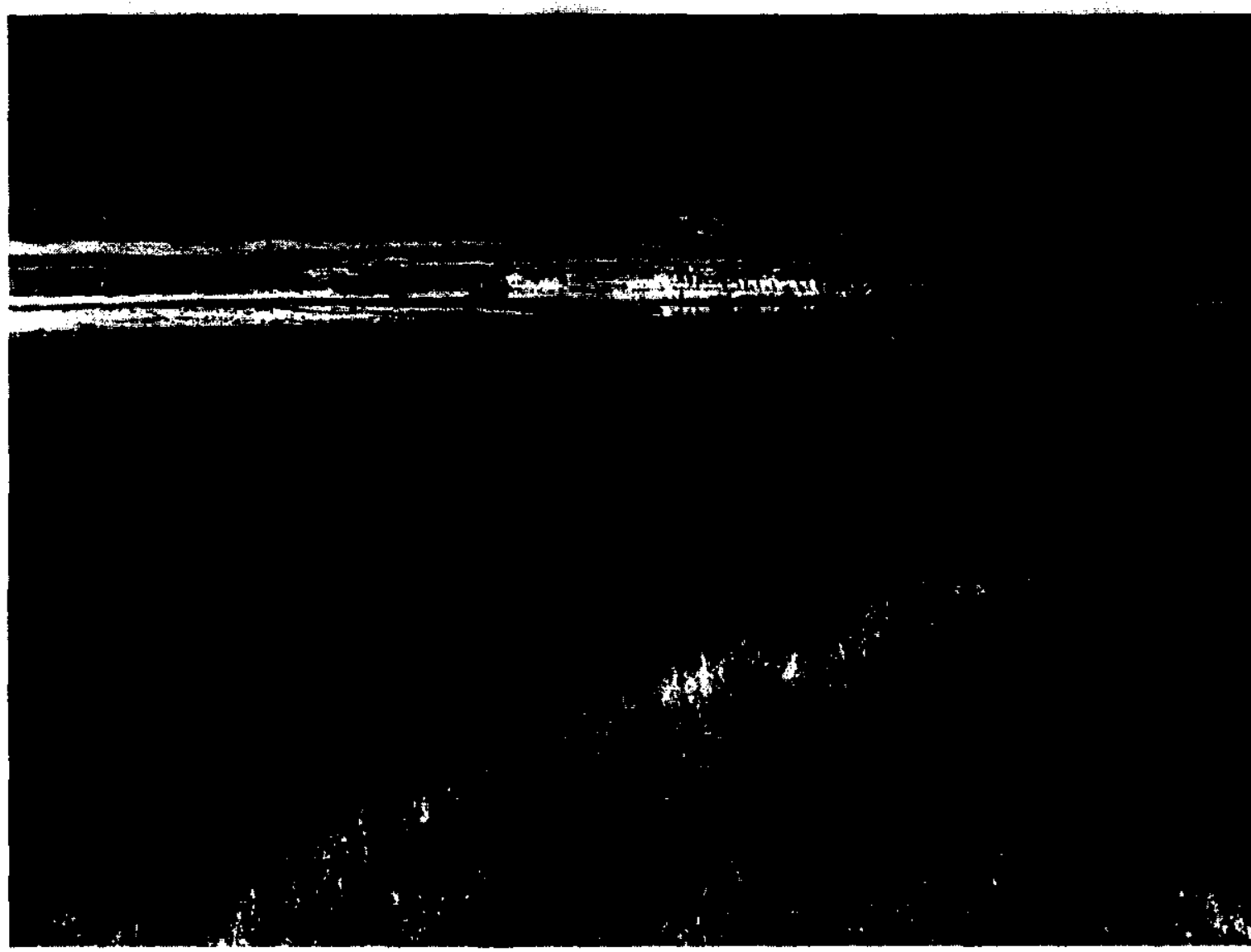

Fluor Hanford

A Fluor Global Services Company 
PHMC Environmental Management Perotur Report Decentser 20017

\section{Table of Contents}

Section

Executive Summary A

\section{The Plateau}

Waste Management B: 1

Analytical Services (222-S, HASP, WSCF) B: 2

Nuclear Material Stabilization. C: 1

\section{The River}

River Corridor C: 2

Spent Nuclear Fuel. D

Advanced Reactors Transition .................................................E EM - 50 Science \& Technology Activities ....................................F

\section{The Future}

HAMMER

\section{Multiple Outcomes}

Landlord H

Support

National Programs.................................................................... J 


\section{INTRODUCTION}

The purpose of this report is to provide the Department of Energy Richland Operations Office (DOE-RL) a monthly summary of the Project Hanford Management Contractor's (PHMC) Environmental Management (EM) performance by Fluor Hanford (FH) and its subcontractors. In addition to project-specific information, it includes some PHMC-level data not detailed elsewhere in the report.

Section A, Executive Summary, provides an executive level summary of the cost, schedule, and technical performance described in this report. It summarizes performance for the period covered, highlights areas worthy of management attention, and provides a forward look to some of the upcoming key performance activities as extracted from the PHMC baseline.

The remaining sections provide detailed performance data relative to each individual Project (e.g., Waste Management, Spent Nuclear Fuels, etc.), in support of Section A of the report. Unless otherwise noted, the Safety, Conduct of Operations, and Cost/Schedule data contained herein is as of October 31, 2000. All other information is updated as of November 17, unless otherwise noted.

"Stoplight" boxes are used to indicate at a glance the condition of a particular area. Green boxes denote on schedule. Yellows denote behind schedule but recoverable. Red is either missed or unrecoverable. 
PHMC Environmental Management Performance Report-December 2000

Section A - Executive Summary

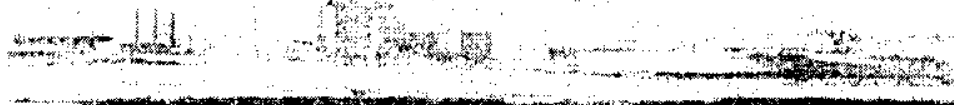
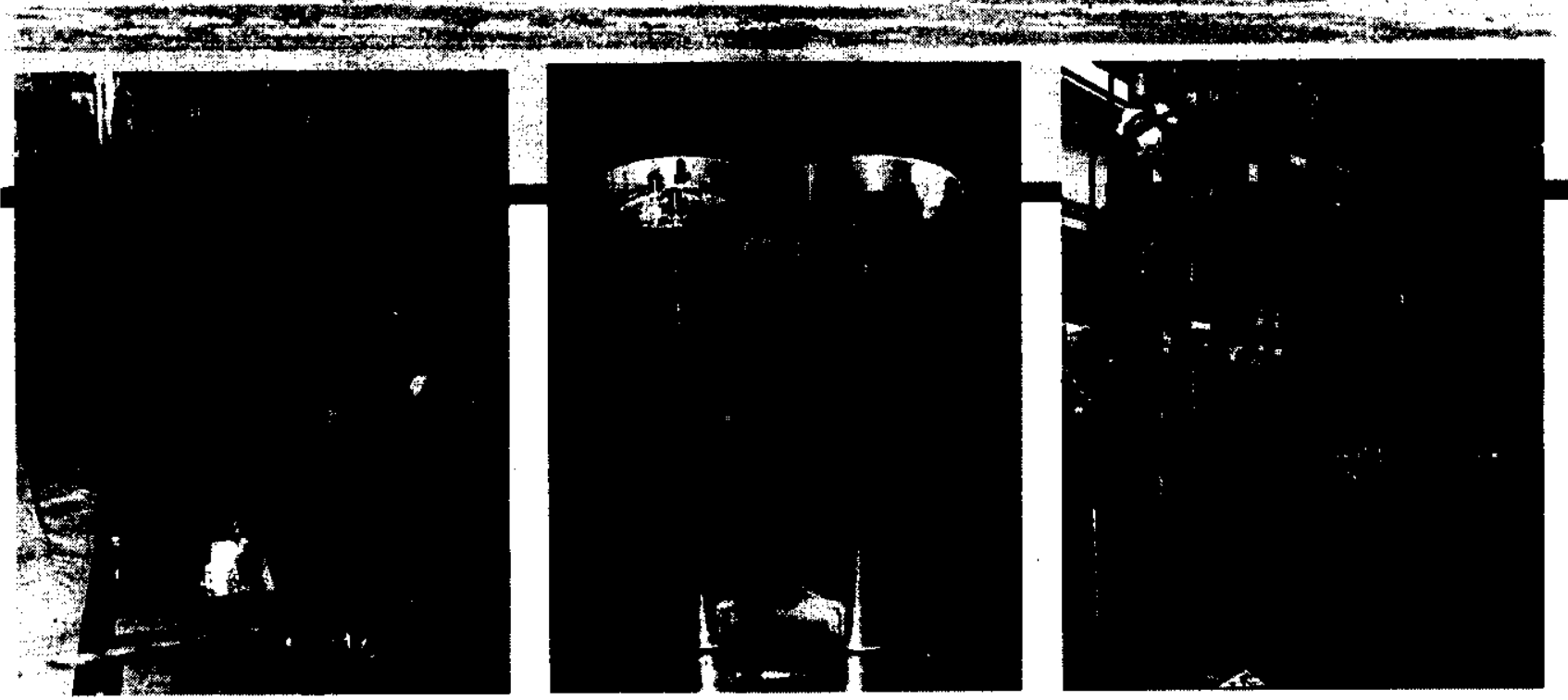

\section{Section A}

\section{Executive Summary}




\section{INTRODUCTION}

This section provides an executive level summary of the performance information covered in

1 this report and is intended to bring to Management's attention that information considered to be most noteworthy. All cost, schedule, milestone commitments, performance measures, and safety data is current as of October 31 . Accomplishments, Issues and Integration items are current as of November 17 unless otherwise noted.

The section begins with a description of notable accomplishments that have occurred since the last report and are considered to have made the greatest contribution toward safe, timely, and costeffective clean up. Following the accomplishment section is an overall fiscal year-to-date summary analysis addressing cost, schedule, and milestone performance. Overviews of safety ensue. The next segment of the Executive Summary, entitled Critical Issues, is designed to identify the high-level challenges to achieving cleanup progress.

The next section includes FY 2001 EM Management Commitment High Visibility Project Milestones and Critical Few Performance Measures.

The Key Integration Activities section follows next, highlighting PHMC activities that cross contractor boundaries and demonstrate the shared value of partnering with other Site entities to accomplish the work. Concluding the Executive Summary, a forward-looking synopsis of Upcoming Planned Key Events is provided.

Note: Milestones tracked and reported in this report consist of two Department of Energy levels. In descending order these levels are 1) Department of Energy-Headquarters (HQ), and 2) Richland Operations (RL). Because it is also useful to distinguish milestones based on specific drivers, the Site applies a designation for those milestones created or tracked to meet the requirements of Enforceable Agreements (EAs). When a milestone satisfies both an EA requirement and a milestone level, it is categorized as both. However, in order to avoid duplicate reporting, this report accounts for each milestone only once. Where an overlap exists between EA and a level (i.e., HQ or RL), the milestone is reported as EA. Additionally, Tri-Party Agreement (TPA) Major and Interim milestones are EA milestones. TPA milestones that are not enforceable are called Target milestones and are included in the TPA/EA milestone tables found in the applicable Project Sections.

\section{NOTABLE ACCOMPLISHMENTS}

\section{TRU WASTE SHIPMENTS TO WIPP CONTINUE}

The shipment of Transuranic (TRU) waste scheduled to leave Hanford on November 9, 2000, was delayed due to concerns over the weather and the condition of the roads in northeastern Oregon. The shipment was completed on November 11,2000 with concurrence from all parties that the weather was acceptable.

\section{PFP METALS STABILIZATION ACCELERATED}

The processing of plutonium metals was initiated on September 29, six weeks ahead of schedule. Early startup of this milestone effort supports a Spring, 2001 Defense Nuclear Facilities Safety Board (DNFSB) commitment to complete packaging of the metal inventory. 
MORE MATERIALS TO BE DISPOSED

The Uranium Disposition Project completed repackaging of four drums of uranium dioxide powder in preparation for shipment to the DOE Portsmouth site in Ohio.

\section{PFP PROJECT W-460 ACTIVITIES CONTINUE}

Fabrication of the 2736-ZB Bagless Transfer System (BTS) and Outer Can Welder (OCW) remain on schedule for shipment from Westinghouse Savannah River Company (WSRC) on January 8 , 2001 and February 14, 2001, respectively. This second system will double the thermal stabilization capability and eliminate " building to building" material transfers.

\section{SNF READINESS REVIEWS CONTINUE}

The RL Operational Readiness Review (ORR) on the Canister Storage Building (CSB), K West (KW) Basin, and Project transportation systems was successfully completed. A significant number of good practices were identified during the RL ORR. The Contractor ORR for the Cold Vacuum Drying (CVD) Facility was also completed.

\section{Performance Data and Analysis}

he following provides a brief synopsis of overall PHMC Environmental Management (EM)
cost, schedule, and milestone performance.

\section{FY 2001 Cost and Schedule Performance}

Cost Performance - FY 2001 year-to-date cost performance reflects a seventeen percent ( $\$ 4.7$ million) favorable cost variance. Detailed variance analysis explanations can be found in the Project Sections.

Schedule Performance - There is a FY 2001 year-to-date seven percent ( $\$ 2.1$ million) unfavorable schedule variance that is within the established $+10 /-7.5$ percent threshold. Detailed variance analysis explanations can be found in the Project Sections. 


\section{Baseline Performance Status \\ Fy 2001 Cost / SChedule Performance - All Fund Types Cumulative to Date Status (\$M)}

DATA THROUGH OCTOBER 31, 2000

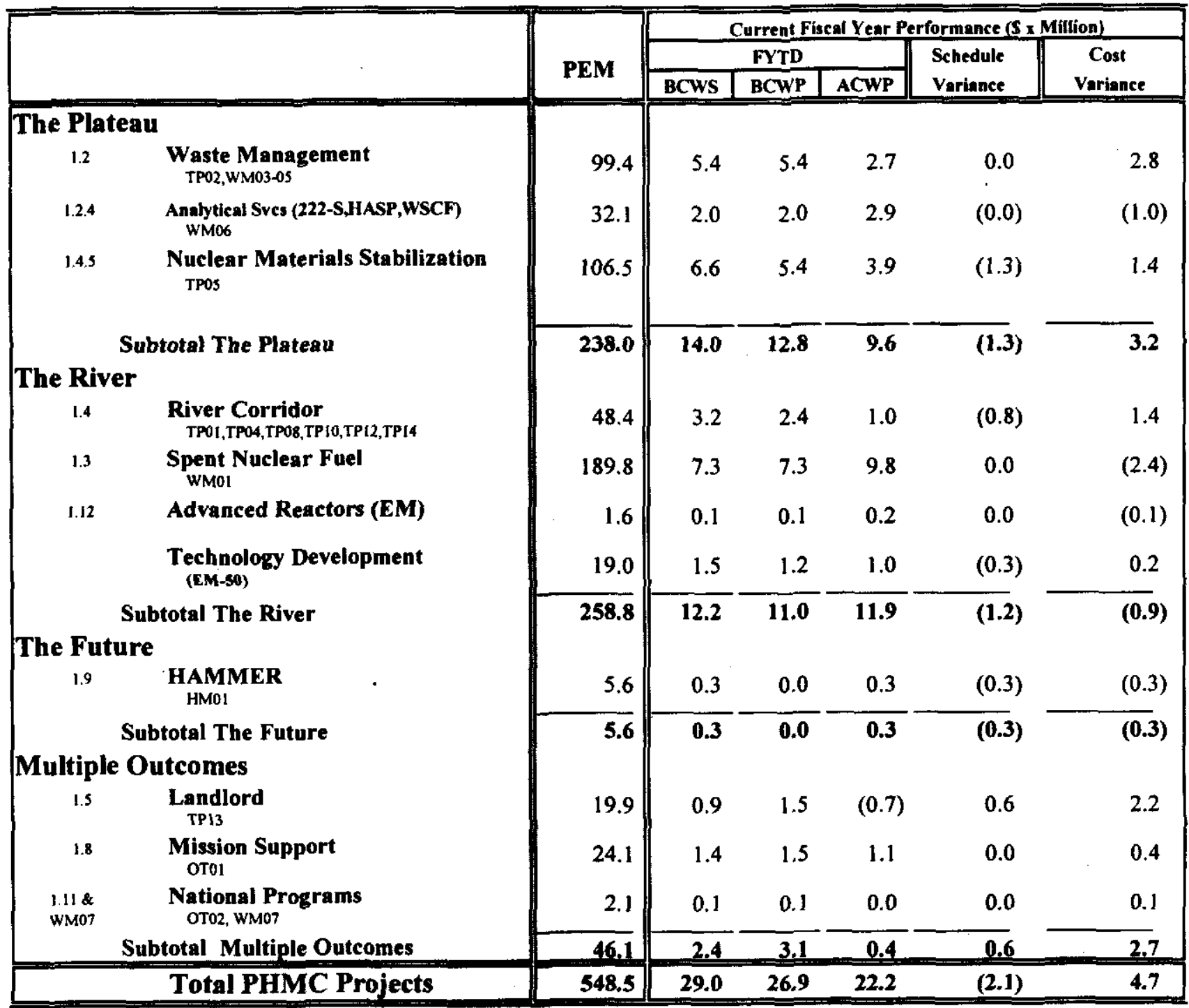

Notes:

Column headings [Budgeted Cost of Work Scheduled (BCWS), Budgeted Cost of Work Performed (BCWP), etc.] are defined in the glossary at the end of the report. Calculations are based on Project Baseline Summary detail. Waste Management, Analytical Services, River Corridor, and Nuclear Materials Stabilization have included RL-Directed costs (e.g. steam and laundry) in the Project Execution Module (PEM) BCWS. Technology Development does not include ORP/RPP TTPs currently reported in the RL Dataset in PEM. 


\section{FY 2001 Cost / Schedule PerformanCe INDices (MONTHLY AND FYTD)}

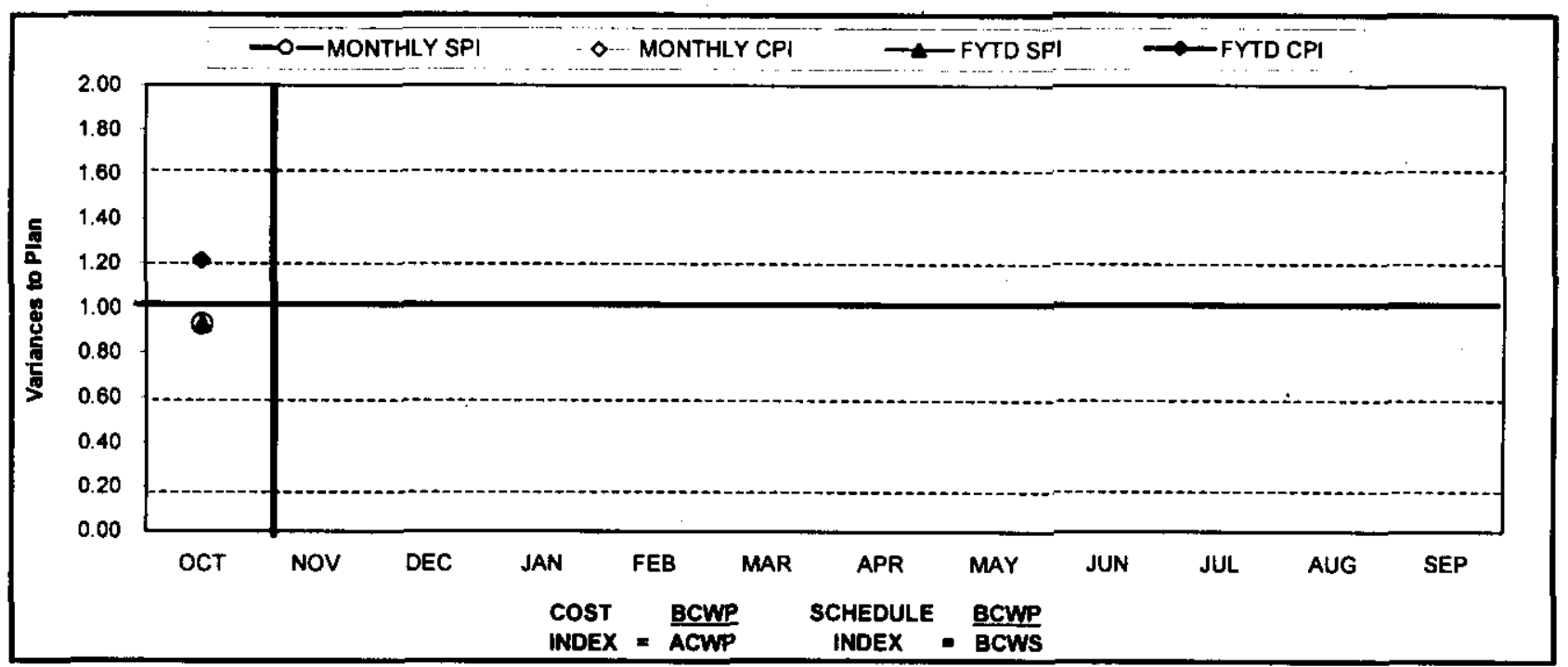

\begin{tabular}{|c|c|c|c|c|c|c|c|c|c|c|c|c|}
\hline $\begin{array}{r}\text { FY } 2001 \\
\end{array}$ & OCT & NOV & DEC & JAN & FEB & MAR & APR & MAY & JUN & JUL & AUG & SEP \\
\hline MONTHLY SPI & 0.93 & & & & & & & & & & & \\
\hline MONTHLY CPI & 1.21 & & & & & & & & & & & \\
\hline FYTD SPI & 0.93 & & & & & & & & & & & \\
\hline FYTD CPI & 1.21 & & & & & & & & & & & \\
\hline MONTHL,Y BCWS & S 29,007 & $5,44,808$ & 39,023 & $5 \quad 49,418$ & $5 \quad 39,119$ & 41,632 & 43,282 & 54,385 & 41,118 & 41,502 & 53,733 & 71,193 \\
\hline MONTHLY BCWP & S 26,898 & & & & & & & & & & & 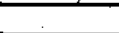 \\
\hline MONTHLY ACWP & $\$ 22,181$ & & & & & & & & & & & \\
\hline FYTD BCWS & S 29,007 & $\$ 73,815$ & $5 \quad 112.839$ & S 162,256 & $5 \quad 201.375$ & $\$ \quad 243,007$ & S 286,289 & $5 \quad 340,674$ & S 381,792 & S 423.294 & S 477,027 & $\begin{array}{ll}5 & 548.219\end{array}$ \\
\hline FYTD BCWP & S 26,898 & & & & & & & & & & & \\
\hline FYTD ACWP & $\$ 22,181$ & & & & & & & & & & & \\
\hline
\end{tabular}

\section{Milestone Performance}

Milestones represent significant events in project execution. They are established to provide a higher level of visibility to critical deliverables and to provide specific status about the accomplishment of these key events. Because of the relative importance of milestones, the ability to track and assess milestone performance provides an effective tool for managing the PHMC EM cleanup mission.

FYTD milestone performance (Enforceable Agreement [EA], U.S. Department of EnergyHeadquarters [DOE-HQ], and RL) shows that two milestones were completed on or ahead of schedule and two milestones are overdue. The two overdue milestones are associated with one project: Spent Nuclear Fuel (Section D).

In addition to the FY2001 milestones described above, there is one overdue milestone [Waste Management (Section B: 1)] from FY1999 and two [Spent Nuclear Fuels (Section D) and River Corridor (Section C: 2)] from FY2000. Further details regarding these milestones may be found in the referenced Project Sections.

FY 2001 information is depicted graphically below and on the following page. For additional details related to the data in the graphs and prior year milestones, refer to the relevant project section titled "Milestone Exception Report." 
FY 2001 information reflects the Phase 1 MultiYear Work Plans (MYWPs). Changes in both the number and type of milestones from month to month are the result of Baseline Change Requests (BCRs) approved during the year.

\section{TOTAL ALL HANFORD PROJECTS}

MILESTONE ACHIEVEMENT

\begin{tabular}{|c|c|c|c|c|c|c|c|c|}
\hline \multirow[b]{2}{*}{ MILESTONE TYPE } & \multicolumn{4}{|c|}{ FISCAL YEAR-TO-DATE } & \multicolumn{3}{|c|}{ REMAINING SCHEDULED } & \multirow[b]{2}{*}{$\begin{array}{l}\text { TOTAL } \\
\text { FY } 2001\end{array}$} \\
\hline & $\begin{array}{c}\text { Completed } \\
\text { Early }\end{array}$ & $\begin{array}{c}\text { Completed } \\
\text { On } \\
\text { Schedule }\end{array}$ & $\begin{array}{c}\text { Completed } \\
\text { Late }\end{array}$ & Overdue & $\begin{array}{c}\text { Forecast } \\
\text { Early }\end{array}$ & $\begin{array}{c}\text { Forecast On } \\
\text { Schedule }\end{array}$ & $\begin{array}{l}\text { Forecast } \\
\text { Late }\end{array}$ & \\
\hline inforceable Agreement & 0 & 1 & 0 & 0 & $\underline{0}$ & 9 & 2 & 12 \\
\hline DOE-HQ & $\overline{0}$ & $\overline{0}$ & 0 & 0 & 0 & 2 & $\overline{0}$ & 2 \\
\hline RL & 1 & $\underline{0}$ & 0 & 2 & 9 & 25 & $\underline{0}$ & 37 \\
\hline Total Project & 1 & 1 & 0 & 2 & 9 & 36 & 2 & 51 \\
\hline
\end{tabular}

Total Project (FYTD)

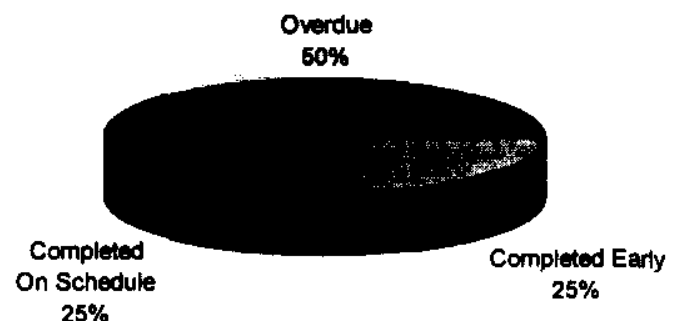


MILESTONE EXCEPTIONS

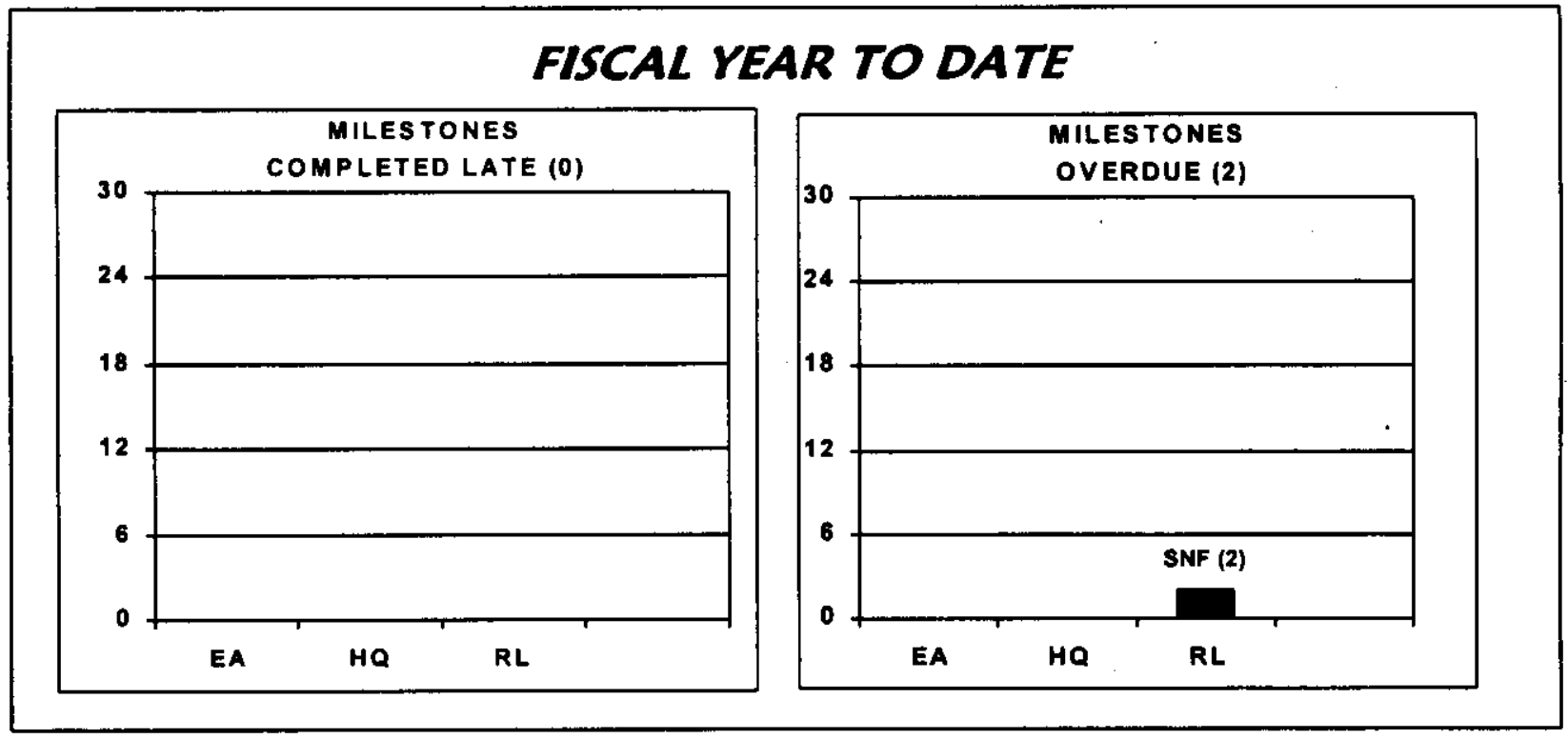

\section{REMAINING SCHEDULED}

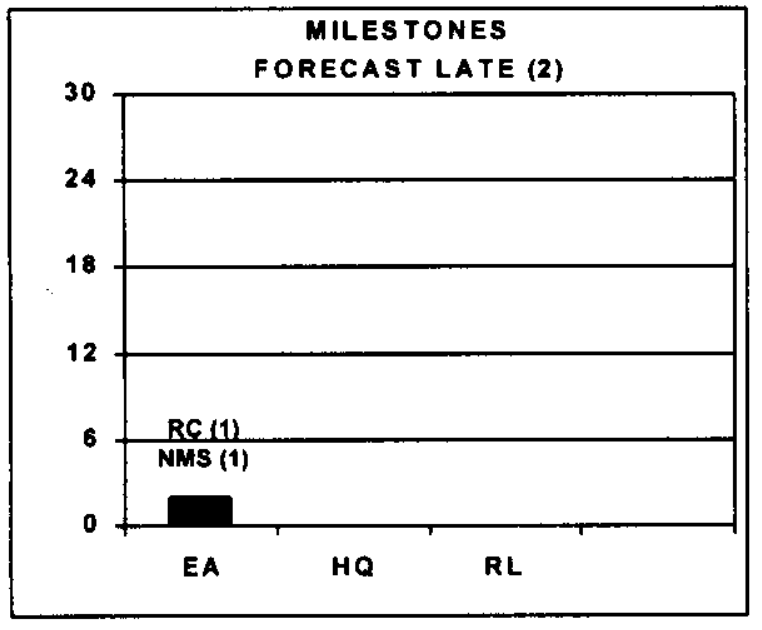

These charts provide detail by project and milestone level / type for milestones

- Completed Late

- Overdue

- Forecast Late

- Detailed information can be found in the individual project sections 


\section{SAFETY OVERVIEW}

The focus of this section is to document trends in occurrences. Improvements in these rates are due to the efforts of the PHMC workforce as they implement the Integrated ES\&H Management System (ISMS), work towards achieving Voluntary Protection Program (VPP) "star" status, and accomplish work through Enhanced Work Planning (EWP). Safety and health statistical data is presented in this section.

\section{Significant Safety and Health Events}

The Waste Management (WM) Project has demonstrated a significant improvement in their OSHA recordable case rate. WM has recently achieved one million safe work hours without a lost workday case.

The Analytical Services (AS) Project OSHA Recordable Case Rate did have a significant increase in the fourth quarter of FY 2000. AS has been conducting ergonomic evaluations to reduce workplace injuries, and reported taking ergonomic actions at the November Presidents' Zero Accident Council Meeting. There were no new OSHA recordable cases for October 2000.

The Nuclear Material Stabilization (NMS) Project DOE Safety Cost Index and Lost Away Workday Case Rate are zero. The Employee-led Zero Accident Council has been instrumental in the improvement in workplace safety.

The River Corridor (RC) Project OSHA Recordable Case Rate remains low, however, there has been a significant increasing trend with four cases during June 2000 through August 2000. RC has recently achieved one million safe work hours without a lost workday case.

The Spent Nuclear Fuels (SNF) Project OSHA Recordable case rate is stable at a relatively high value (current baseline is 2.5 cases per 200,000 hours). SNF reached two million safe work hours during November 2000.

The Landlord (LL) Project Lost Away Case Rate is very good, and LL is close to exceeding two million safe work hours. LL may be showing some signs of improvement in their OSHA recordable case rate, but it is not yet significant.

Due to space constraints, FY1996 and FY1997 data is not portrayed on the following graphs. 


\section{Total OSHA Recordable Case Rate}

Cases per 200,000 hours

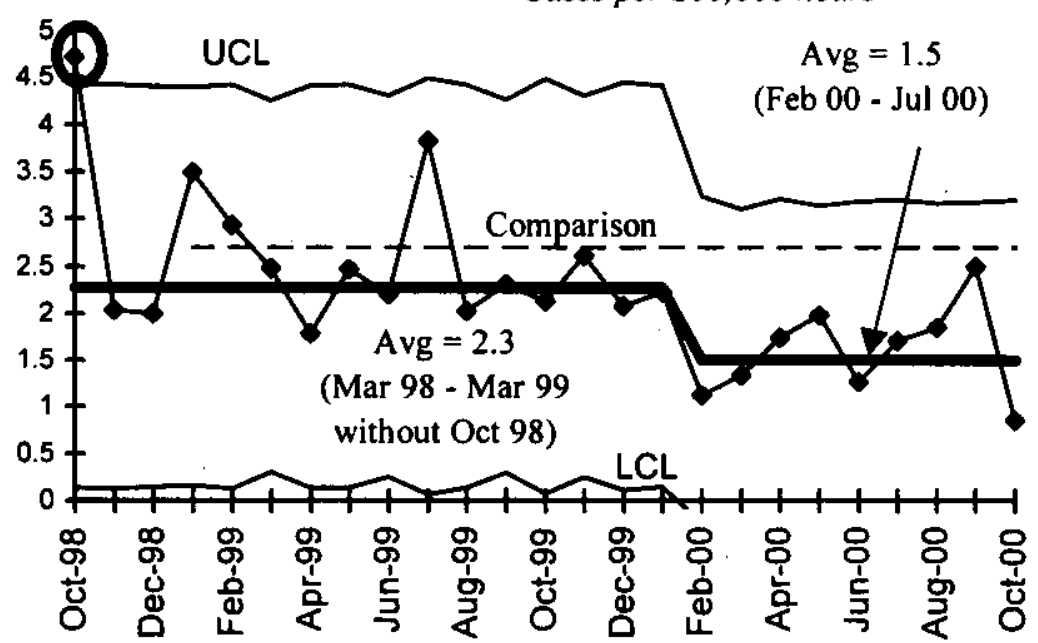

FY $2000=1.9$

FY 2001 to date $=0.9$

Contractor Comparison

Average $=2.7$ (CY99)

Recent data have been stable within the new 1.5 baseline. The FH Team continues to look for opportunities for injury reduction in the areas of ergonomics and lacerations.

FH implemented a program to target an OSHA Recordable Case Rate of 0.9. The Fluor Global Services goal is 1.0. This is in line with Fluor's corporate value of safety and our commitment to the safe clean-up of the Hanford Site.

A team investigating Health Physics Technician injures reported findings and actions at the November 2000 Presidents Zero Accident Council. HPT's are the leading source of injuries, and these are primarily ergonomically related. Actions are being taken to address human factors issues with equipment and the aging workforce through the cooperation of the HPT's, their management, ES\&H, and HEHF.

\section{OSHA LOST/RESTRICTED WORKDAY CASE RATE}

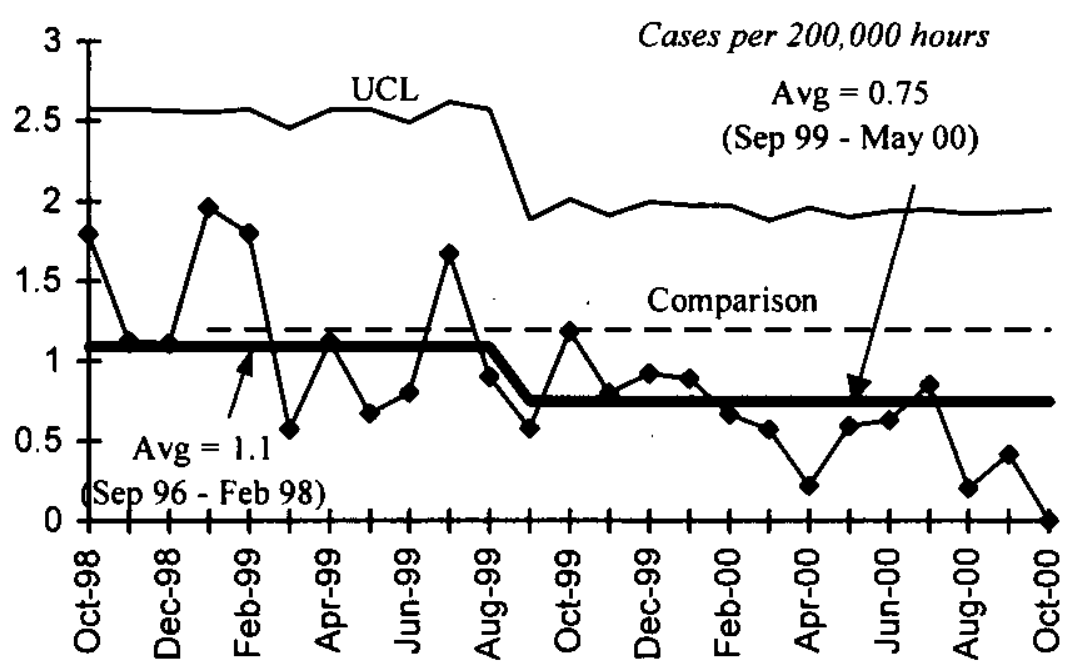

FY $2000=0.65$

\section{Green}

FY 2001 to date $=0.00$

Contractor Comparison Average $=1.2$ (CY99)

Data continue to be at or below the current baseline average established for September 1999 - May 2000, but is not yet a significant trend.

The FH Team has accumulated over 10 million safe work hours since midDecember 1999 without any new lost away workday cases. 


\section{First Aid Case Rate}

Cases per 200,000 hours

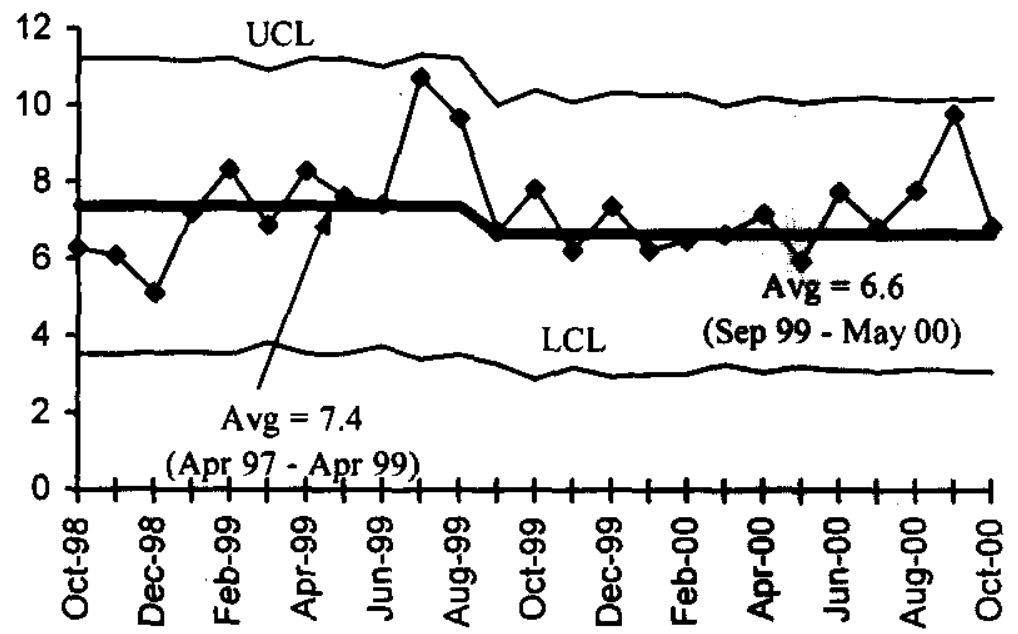

First Aid Rate undergoes seasonal cycles. Increases occur in warmer weather due to insect and animal encounters, and due to wind related minor injuries. First Aid case rate has remained relatively stable, a good indicator that injuries are not being under-reported.

There was a nearly significant increase in September 2000 , but the increase appears to be primarily related to summer increases in insect and wind hazards. Past activities to increase awareness of wind hazards and actions to control insects and animals appear to be having an effect.

The hazard of receiving wind-borne debris in eyes when working outdoors has considerably increased due to the bare, exposed sand left by the Hanford wildfire.

\section{DOE Safety Cost Index}

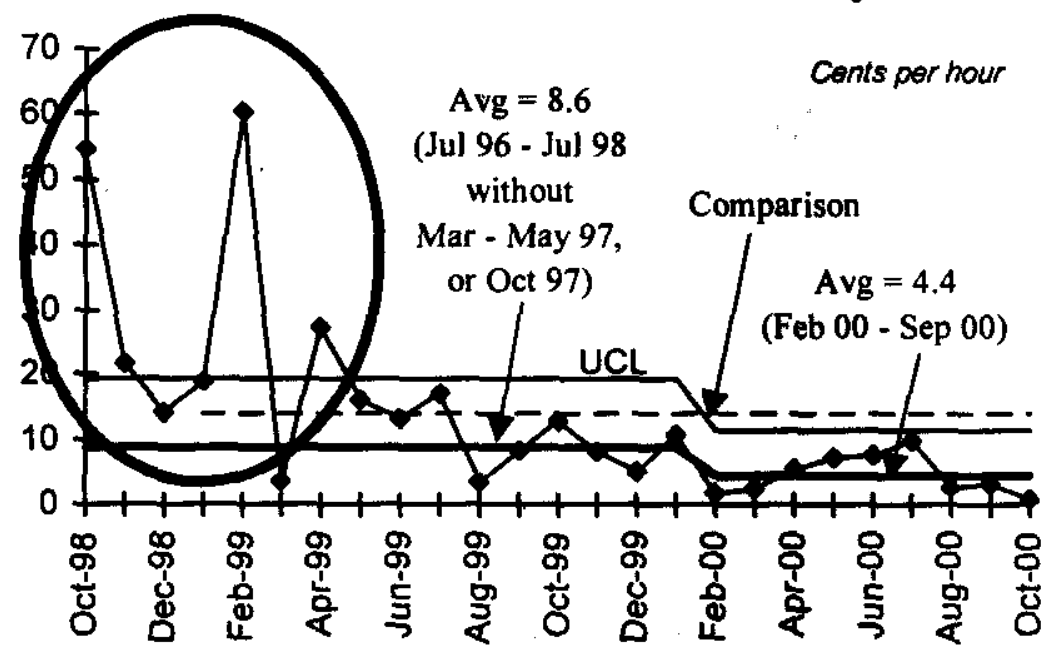

FY $2000=6.3$

FY 2001 to date $=0.9$

Contractor Comparison Average = 13.9 (CY99)

This indicator has had new average and control limits calculated reflecting recent significant decreases in the cost index. This decrease is primarily related to the reduction in Lost Away workday injuries. Past data continue to be corrected as further days accumulate on any work restrictions or lost days.

\section{CRITICAL ISSUES}

- INABILITY TO MEET ACCEPTANCE CRITERIA DELAYS CELL CLEANUP Hot spots on the bottom of Steel Waste Disposal Boxes loaded with Rectangular Grout Containers from the 324 Building are more radioactive than the current Central Waste Complex (CWC) acceptance criteria of one rem per hour. The shipment schedule/in-cell work schedule has been delayed, but several actions are being pursued. See the River Corridor Project Section C: 2 for more information. 


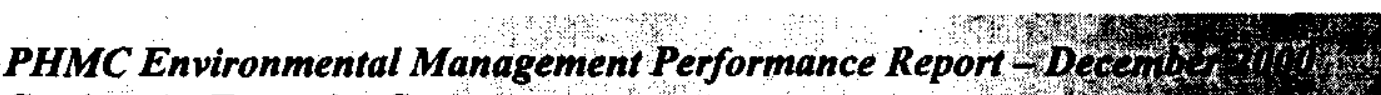 \\ EM MANAGEMENT COMMITMENT MILESTONES}

EM Management Commitment Milestones are currently being negotiated and will be reported when approved.

\section{Critical Few Performance InCentives}

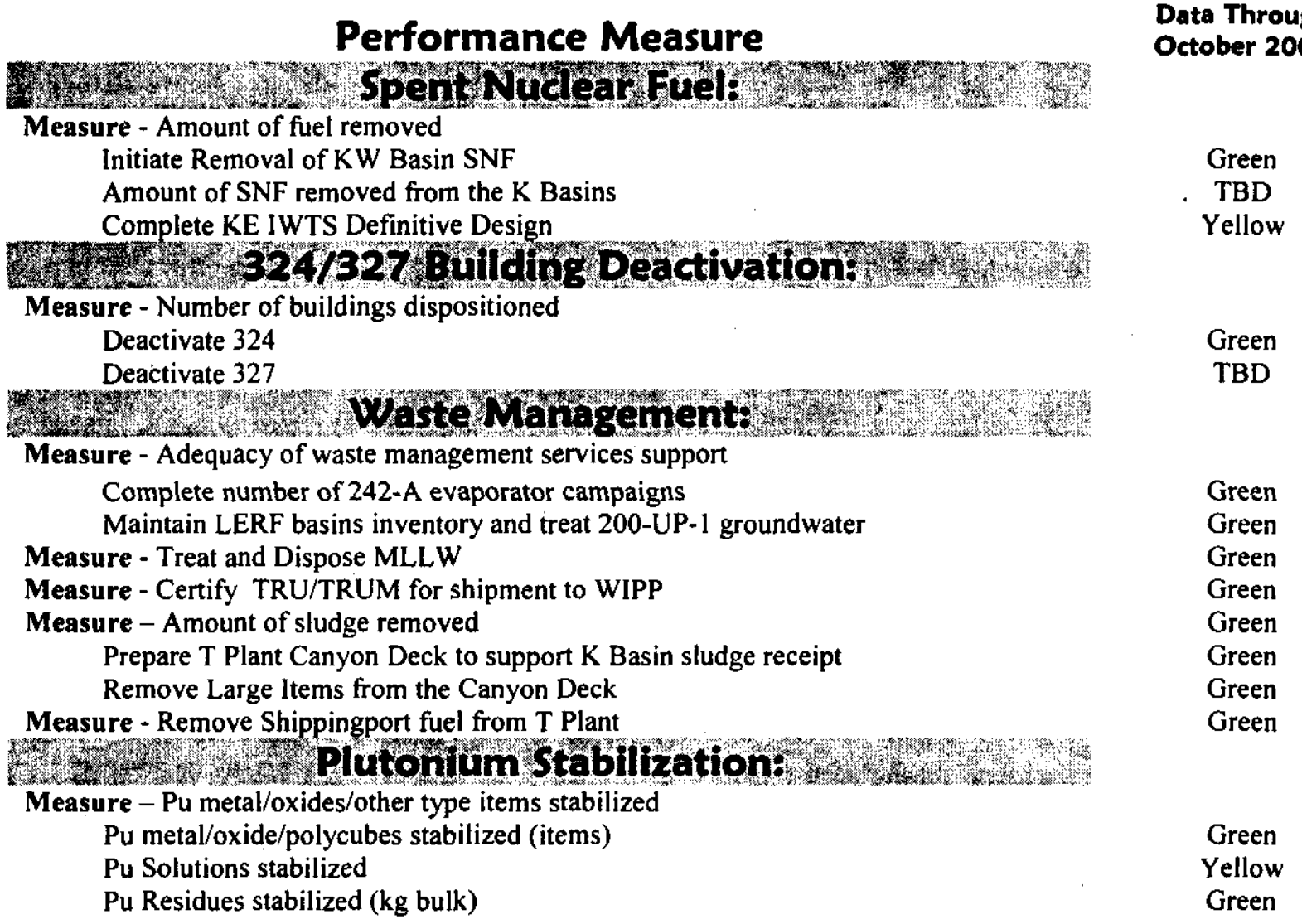

Yellows noted above are behind schedule but recoverable. Red is either missed or unrecoverable. Details can be found in the Project Sections.

\section{KEY INTEGRATION ACTIVITIES}

The following are the key technical integration activities that are currently underway and cross project/contractor lines. These activities are being addressed by inter-discipline and interproject groups and demonstrate that Hanford Site contractors are working together to accomplish the EM Clean up mission.

- Waste Management (WM) continues working with RL, DOE-HQ and other Sites to develop and define Hanford's role in disposing of waste from other sites. A comprehensive strategy will be developed for the DOE complex low-level waste with the Nevada Test Site by the end of FY 2001.

- WM supporting the Office of River Protection Waste Treatment Plant. 


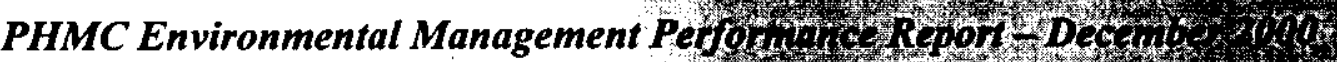

Section A-Executive Summary

- WM supporting visits from both the DOE-Idaho Program Office and the Office of the Inspector General in regards to opportunities for treatment/disposal of Idaho National Engineering Environment Laboratory (INEEL) wastes at Hanford.

- WM continues working with PNNL, EM-50 and Mixed Waste Focus Area (MWFA) to obtain funding in support of mixed waste processing.

- Analytical Services continues to support ORP efforts to establish required analytical support for Waste Treatment Plant (WTP) design and operation.

- Through involvement with the National Facility Deactivation Initiative, Hanford, Rocky Flats, and Savannah River, a joint proposal for a contaminated large equipment size reduction system deployable at the three sites was completed and submitted. River Corridor Project and FH Technology Management personnel met with PAR Systems to preview the glovebox size reduction system that is being developed for the Rocky Flats site. This is an ex-situ system that is scheduled to begin operation in the fall of 2001. Hanford should benefit from the experience gained at Rocky Flats over the next several years.

- Spent nuclear fuel (SNF) final disposition interface activities, including Office of Civilian Radioactive Waste Management (OCRWM) Quality Assurance (QA) Program implementation, is ongoing with the National SNF Program. The SNF Project participated in a National SNF Program strategy meeting that resulted in commitments for resolution of issues related to OCRWM data qualification requirements, licensing strategy for RL-owned SNF inventories, and analyses for evaluating acceptability of $\mathrm{N}$ Reactor fuel receipt at Yucca Mountain.

- The SNF Project and the River Corridor Project interfaced on contracting strategies and records management for 324 Building (B Cell) SNF removal.

- The SNF Project and Waste Management Project continued preparations for K Basins' sludge removal and Shippingport (PA) Pressurized Water Reactor Core 2 SNF removal.

- Bechtel Hanford, Inc. transmitted a revised transfer plan for SNF discovered during upcoming $105 \mathrm{~F}$ and $105 \mathrm{H}$ reactor basins deactivation for SNF Project review and approval. This transfer plan incorporated earlier SNF Project comments.

\section{Upcoming Planned Key Events}

The following key events are extracted from the authorized baseline and are currently expected

1 to be accomplished during the next several months. Most are Enforceable Agreement (EA), HQ or DNFSB Milestones.

\section{Waste Management:}

- Accelerate Readiness at T Plant to Receive and Store Spent Nuclear Fuel K Basin Sludge -

- Complete procedures, training, and Operations Readiness Review (ORR) by June 2001.

- Complete entire deck clearing in FY 2001.

- Complete safety basis documentation and long lead procurements in FY 2001.

- Install handling, drying and loading equipment in FY 2001. 
PHMC Environmental Management Performance Report-December 200

Section A-Executive Summary

\section{Nuclear Materials Stabilization:}

- Receive delivery of the 2736-ZB BTS and Outer Can Welder (OCW) during the second quarter of FY 2001.

- Complete repackaging of Pu metal inventory by March 31, 2001.

- Complete modifications to one vault cubicle by April 2, 2001.

- Complete repackaging and shipping of Rocky Flats Ash to the Central Waste Complex (CWC) by April 30, 2001.

- Initiate polycube stabilization in third quarter of FY 2001.

\section{River Corridor Project:}

- Complete Facility Evaluation Board review during first quarter of FY 2001.

- Implement technical update of 324 Authorization Basis (Safety Analysis Report) by midDecember, 2000 and implement technical update of 327 Authorization Basis (Basis of Interim Operation) by March, 2001.

- Complete Removal of 324 Building Radiochemical Engineering Cell (REC) B Cell Mixed Waste (MW) and Equipment in the first half of FY 2001.

- Begin 224-T facility initial entry and characterization by early March 2001.

- Complete shipment of approximately 235 metric tons of excess uranium billets and approximately 5 metric tons of uranium dioxide to the DOE Portsmouth site in Ohio by March 31,2001 and disposition approximately 140 metric tons of surface contaminated uranium fuel by June $30,2001$.

- Complete shipment of B Cell waste currently stored in A Cell to the 200 Areas in July 2001.

\section{Spent Nuclear Fuels:}

- Begin K West (KW) Basin fuel removal, drying and storage operations in November 2000.

- Complete RL Operational Readiness Review for CVD in November 2000.

- Start KW Basin canister cleaning in December 2000.

- Complete K East (KE) Basin Sludge Loadout conceptual design in January 2001.

- Complete KE Basin Integrated Water Treatment System definitive design in April 2001.

- Continue receipt of MCO shipments through FY 2001.

\section{Landlord}

- Complete Project L-309, "Replace Main Water Lines" by December 22, 2000.

- Complete installation of a chlorine containment system for Project L-303, "200 West Area Chlorine Mitigation" by January 31, 2001. 

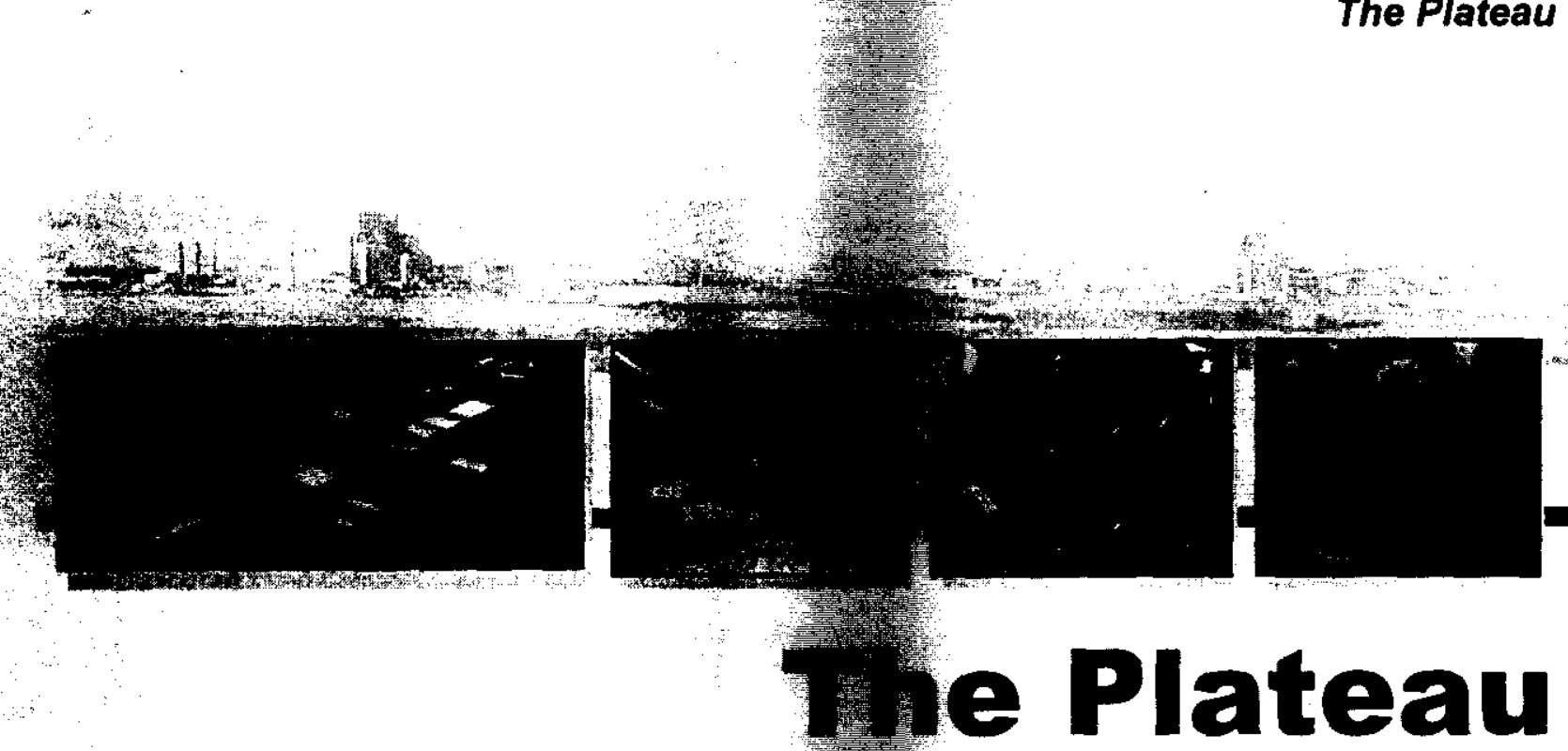

Transitioning the central plateas long-term waste management is a key part of the Hanford vist. the "canyon" facilities, denstiv" and disposing of solid whte the Plutonium Finishing Plant luded in The Plateau are Waste 
PHMC Environmental Management Performance Report - December 2000 Section B1 - Waste Management

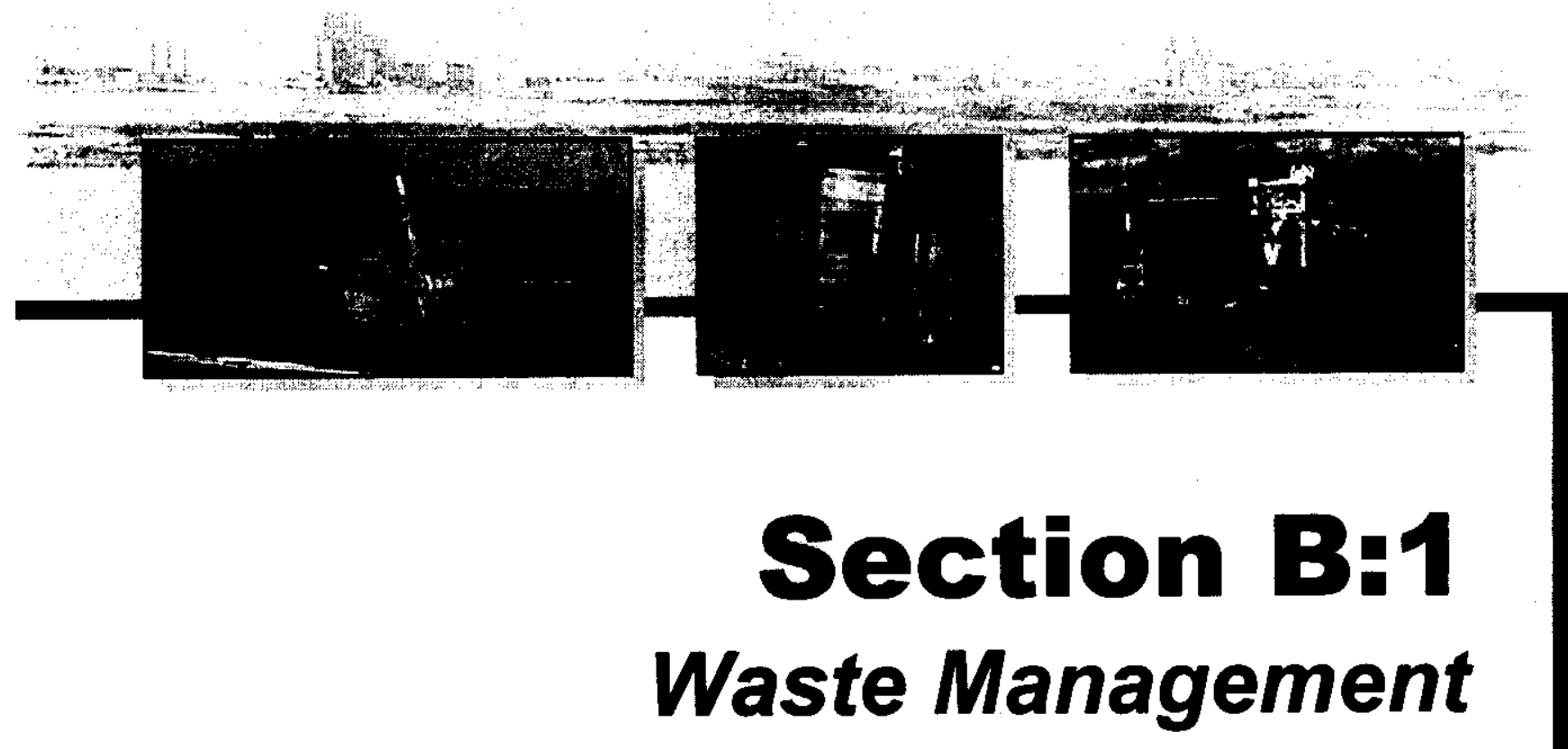

PROJECT MANAGERS

G.H. Sanders, RL (509) $376-6888$

E.S. Aromi Jr., WMH

(509) 372-1033 


\section{SUMMARY}

Waste Management consists of the Solid Waste Storage and Disposal, Project Baseline Summary (PBS) WM03, Work Breakdown Structure (WBS) 1.2.1; Solid Waste Treatment, PBS WM04, WBS 1.2.2; Liquid Effluents - 200 Area, PBS WM05, WBS 1.2.3.1; and the Waste Encapsulation and Storage Facility, PBS TP02, WBS 1.4.2.

PBS WM05 is divided between WBS 1.2.3.1, Liquid Effluents (200 LEF) and WBS 1.2.3.2, 310 TEDF/340 Facility (300 LEF). The 310 TEDF/340 Facility work scope is included in the River Corridor Project, whereas the Liquid Effluents (200 LEF) work scope remains in Waste Management. For the purpose of performance analysis, PBS WM05 is reported in its entirety in the Waste Management Project (WMP), which has the majority of the work scope and funding.

NOTE: Unless otherwise noted, the Safety, Conduct of Operations, Milestone Achievement, and Cost/Schedule data contained herein is as of October 31,2000. Other data is updated as noted.

\section{ACCOMPLISHMENTS}

The shipment of Transuranic (TRU) waste scheduled to leave Hanford on November 9, 2000 was delayed due to concerns over the weather and the condition of the roads in northeastern Oregon. Additionally, the Oregon State expressed concern regarding shipment on a holiday (Veteran's Day). The shipment of 17 cubic meters was completed on November 11, 2000 with concurrence from all parties that the weather was acceptable.

A certified off-site contractor completed permanent repair of the Mixed Waste Trench 34 Leachate Storage Tank's containment liner November 16, 2000.

Three and one-half million gallons of wastewater were processed through the Effluent Treatment Facility (ETF) for the month of October. From October 1, 2000 through November 14, 2000, 4.7 million gallons of wastewater were processed supporting the Environmental restoration Contract 200-UP-1 Groundwater project.

The final report for the Liquid Effluents' Reliability, Availability, and Maintainability (RAM) Analysis was received from Parsons and was distributed for review. The report predicts the availability of the Liquid Effluent Retention Facility (LERF)/ETF and 200 Area Treated Effluent Disposal Facility (TEDF) to receive the liquid effluents from the ORP Waste Treatment Plant. There are no issues with availability of the 200 Area TEDF to receive the non-radioactive liquid effluents. 
The following activities were completed at the Waste Receiving and Processing (WRAP) facility:

$\begin{array}{lll} & \text { Thru } & \text { Thru } \\ & \underline{10 / 31 / 00} & \\ & 11 / 17 / 00 \\ \text { NDE on Drums } & 156 & 240 \\ \text { NDE on Boxes } & 0 & 0 \\ \text { NDA on Drums } & 80 & 164 \\ \text { TRU GB Visual Exam - Drums } & 0 & 0 \\ \text { TRU GB Repackaged Drums } & 0 & 0 \\ \text { LLW GB Drums } & 0 & 0\end{array}$

\section{SAFETY}

WMP has achieved one and a half million project safe hours. There are also significantreductionsin the OSHA recordable case rate, and the Lost/Restricted Workday Case Rate. A new baseline has been established for the OSHA recordable graph at 1.8 cases per 200,000 hours. During the month of October, the WMP experienced no Restricted Workday Cases, six first aid cases, one "report only" (no symptoms) case and one "not job related" case. 
PHMC Environmental Management Performance Report - December 2000

Section B: I-Waste Management
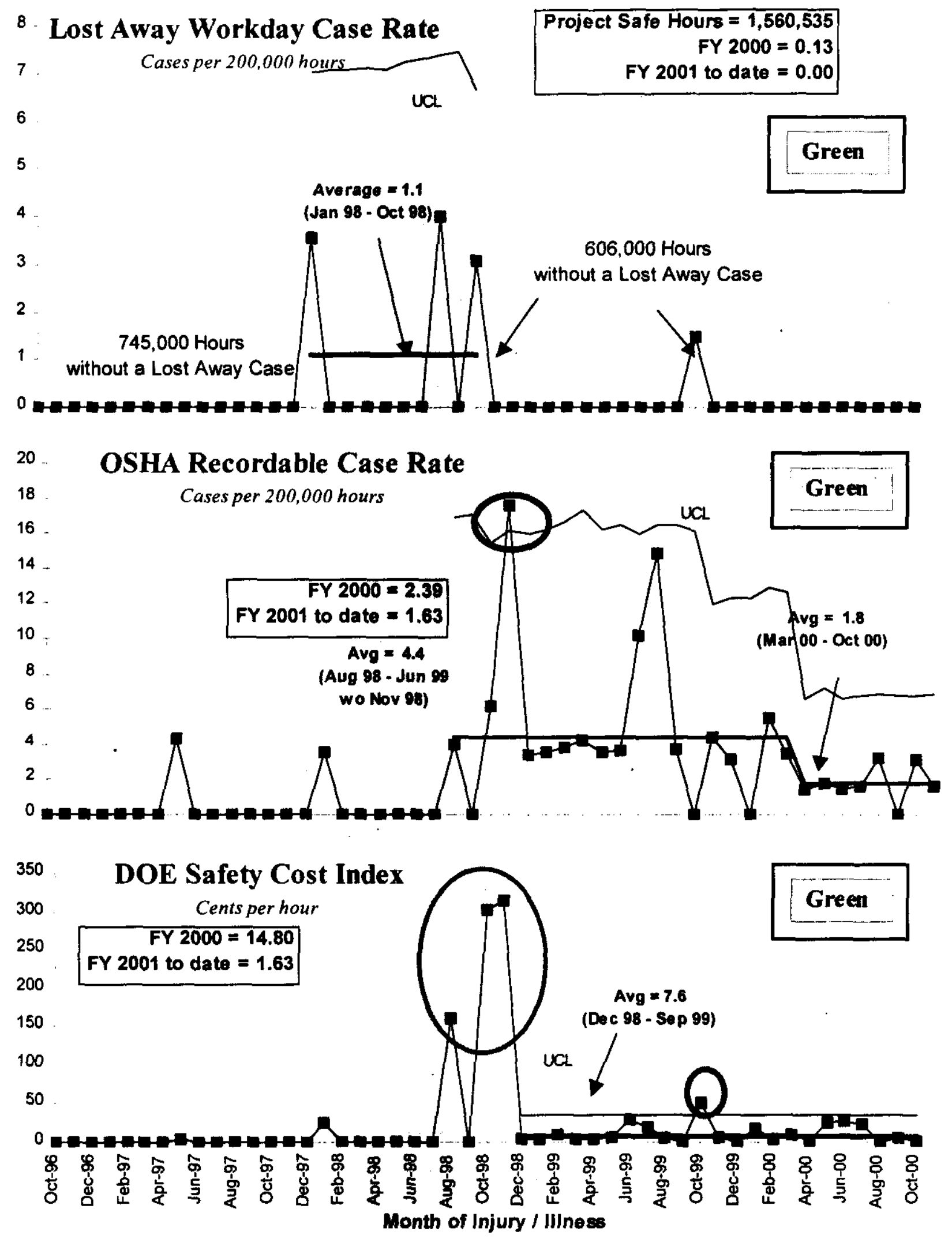


\section{CONDUCT OF OPERATIONS / ISMS STATUS Green \\ Conduct of Operations Index}

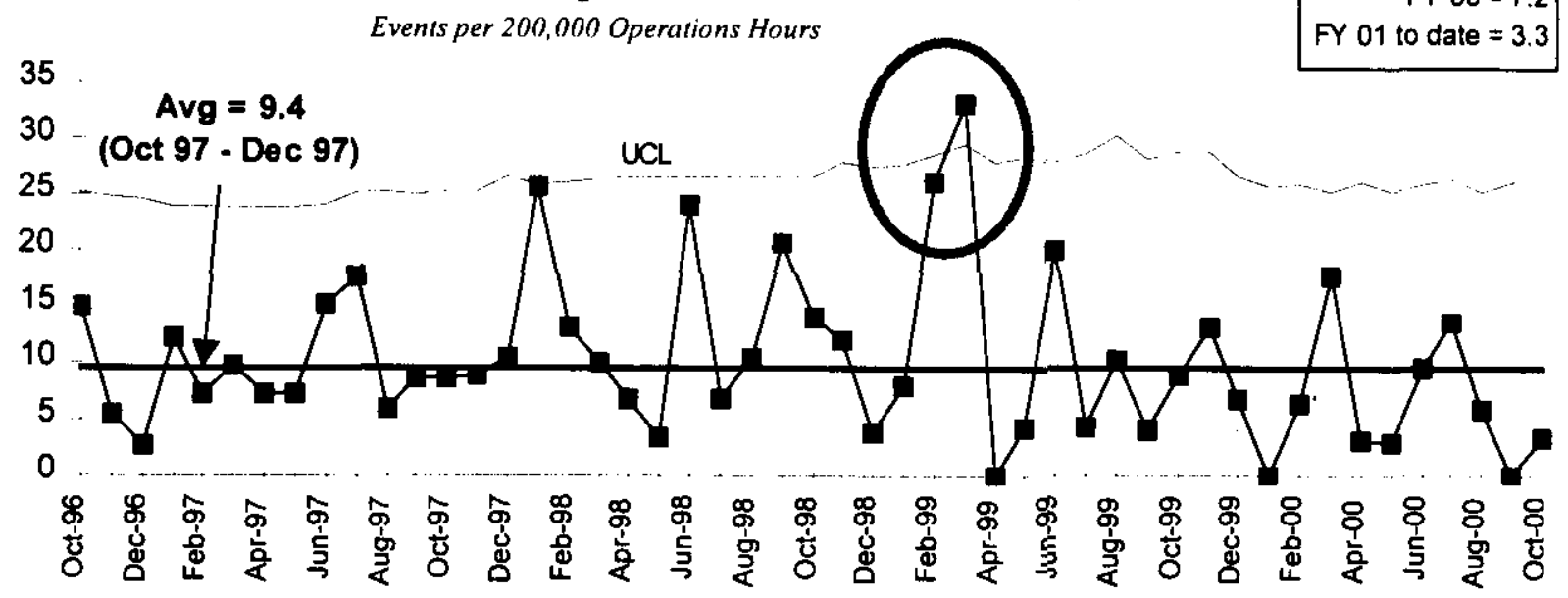

\section{Number of Reports Past 12 Months}

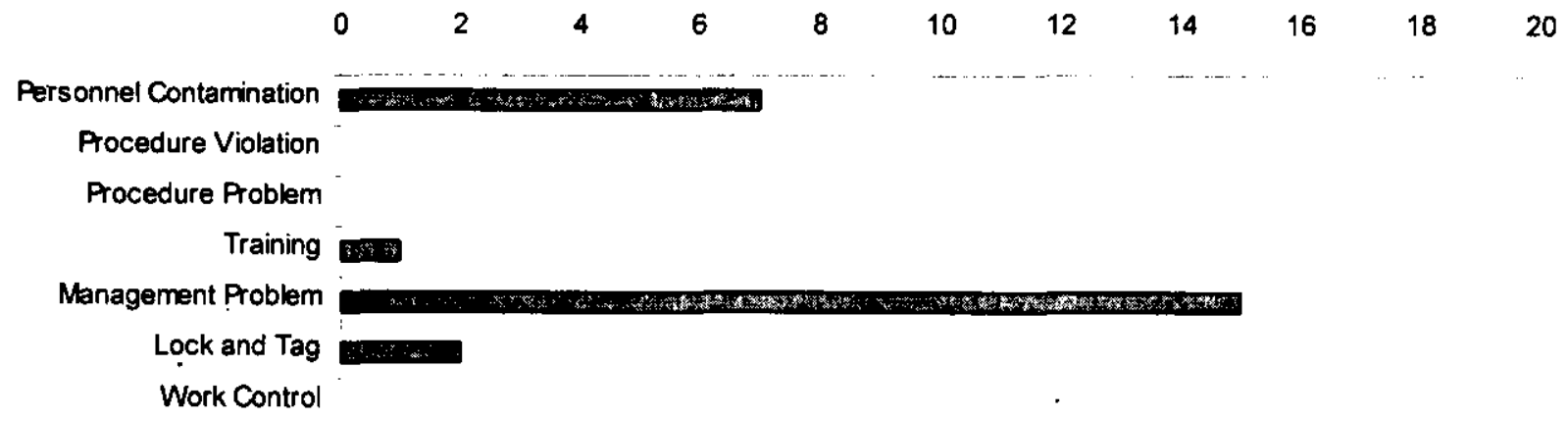

\section{ISMS STATUS}

Completed Activities in October 2000:

Green

- Continued development of PHMC ISMS Sustain and Maintain Plans, including determination of performance objectives and schedules.

- Participants from the Project have been identified to support the ISMS National Conference.

Planned Actions:

- Control of the WMP portion of the MP-003 document will be detailed and distributed as part of the Project level "sustain and maintain" efforts. The project will implement the Sustain and Maintain Plan for ISMS when approved.

- Participate and support the ISMS National Conference on December 5-6, 2000. 


\section{BREAKTHROUGHS / OPPORTUNITIES FOR IMPROVEMENT}

\section{Breakthroughs}

Nothing to report at this time.

\section{Opportunities for Improvement}

Green

Waste Management Strategic Planning - Revision of the Waste Management Project Strategic Plan is underway. A series of workshops have been conducted with the Departments of Energy, Ecology, and the Environmental Protection Agency (EPA). The objective of the effort is to update and improve the Project strategy, to gain regulator "buy-in", to improve the format and presentation of the Strategy, and to develop a basis for the ongoing production of the Multi-Year Work Plan. A series of logic diagrams and an overall schedule graphic have been developed which will serve to improve the communication of the Waste Management Strategic Plan to users/stakeholders. Text development is underway.

Mixed Waste Focus Area - Waste Management continues to work with the Mixed Waste Focus Area (Robotics Product Line) on a technology development/ demonstration activity at Hanford. The details of a demonstration/deployment of size-reduction technologies are being worked out. Initial plans are for a demonstration of size reduction at T Plant during FY 2001, using commercial technologies to size reduce the PUREX Towers TRU currently stored on the canyon deck. This activity supports development of technologies for later application in the M-91 Facility, and also clearing of the deck for sludge receipt. The Mixed Waste Focus Area will provide funding for the activity. A Commerce Business Daily (CBD) notice for size reduction and remote handling technologies has been published.

Land Disposal Restriction (LDR) Report - The legal appeal over the Final Determination continues. Mediation meetings are being held as well as sub-group meetings at the working level to attempt to define acceptable format and data content. Support will be provided as necessary to these activities. PNNL support is available to assist in preparation of the $2001 \mathrm{LDR}$ report. The preparation effort will be initiated as soon as possible, which will be difficult given the changes caused by the mediation efforts.

\section{UPCOMING ACTIVITIES}

Remote-Handled TRU Project Management Plan (PMP) - Support RL meetings with Ecology to address Ecology's August 14, 2000 letter disapproving the PMP.

\section{Accelerate Readiness at T Plant to Receive and Store SNF K Basin Sludge -}

- Complete entire deck clearing in FY 2001.

- Complete safety basis documentation and long lead procurements in FY 2001. Install handling, drying and loading equipment in FY 2001.

- Complete procedures, training, and Operations Readiness Review (ORR) by June 2001. 


\section{Cost Performance (\$M):}

\begin{tabular}{|l|c|c|c|}
\hline & BCWP & ACWP & VARIANCE \\
\hline Waste Management & $\$ 5.4$ & $\$ 2.7$ & $\$ 2.8$ \\
\hline
\end{tabular}

The $\$ 2.8$ million (51 percent) favorable cost variance is primarily in RL-WM03 Solid Waste Storage and Disposal. Further information at the PBS level can be found in the following Cost Variance Analysis.

\section{Schedule Performance $(\$ M)$ :}

\begin{tabular}{|l|c|c|c|}
\hline & BCWP & BCWS & VARIANCE \\
\hline Waste Management & $\$ 5.4$ & $\$ 5.4$ & $\$ 0.0$ \\
\hline
\end{tabular}

There is no schedule variance. Further information at the PBS level can be found in the following Schedule Variance Analysis.

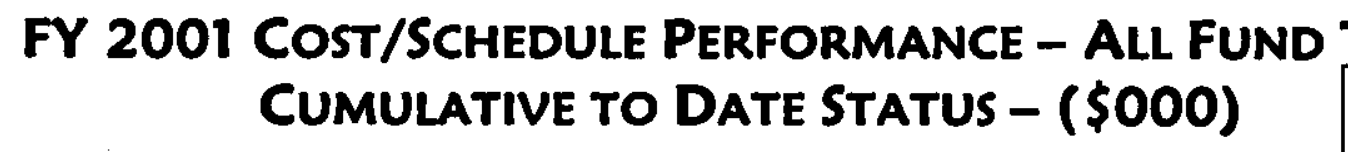
By PBS

PBS WM03 WBS 1.2 .1 PBS WM04 WBS 1.2 .2 PBS WM05 WBS 1.2 .3 PBS TP02 WBS 1.4 .2

Total

\section{FYTD}

Solid Waste Storage \&
Disposal
Solid Waste Treatment
Liquid Effluents -
$200 / 300$ Area
WESF

\begin{tabular}{|c|c|c|c|c|c|c|c|}
\hline BCWS & BCWP & ACWP & sv & $\%$ & cV & $\%$ & PEM* \\
\hline$\$ 1,400$ & $\$ 1,407$ & $\$(494)$ & $\$ 7$ & $1 \%$ & $\$ 1,901$ & $135 \%$ & $\$ 25,276$ \\
\hline$\$ 1,840$ & $\$ 1,833$ & $\$ 1,420$ & $\$(7)$ & $0 \%$ & 413 & $23 \%$ & $\$ 36,151$ \\
\hline$\$ 1,586$ & $\$ 1,597$ & $\$ \uparrow, 194$ & $\$ 11$ & $1 \%$ & 403 & $25 \%$ & $\$ 27,249$ \\
\hline 586 & 589 & 551 & $\$ 3$ & $0 \%$ & 38 & $6 \%$ & $\$ 10,721$ \\
\hline 5,413 & $\$ 5,426$ & \$ 2,671 & $\$ 13$ & $0 \%$ & $\$ 2,755$ & $51 \%$ & \$ 99,397 \\
\hline
\end{tabular}

*PBS WM05 includes the 300 Area Liquid Effluent, which is part of the River Corridor Project. RL-Directed costs (steam and laundry) are included in the Project Execution Module (PEM) BCWS. 


\section{COST/SCHEDUle PERformanCe INDICES (MONTHLY AND FYTD)}

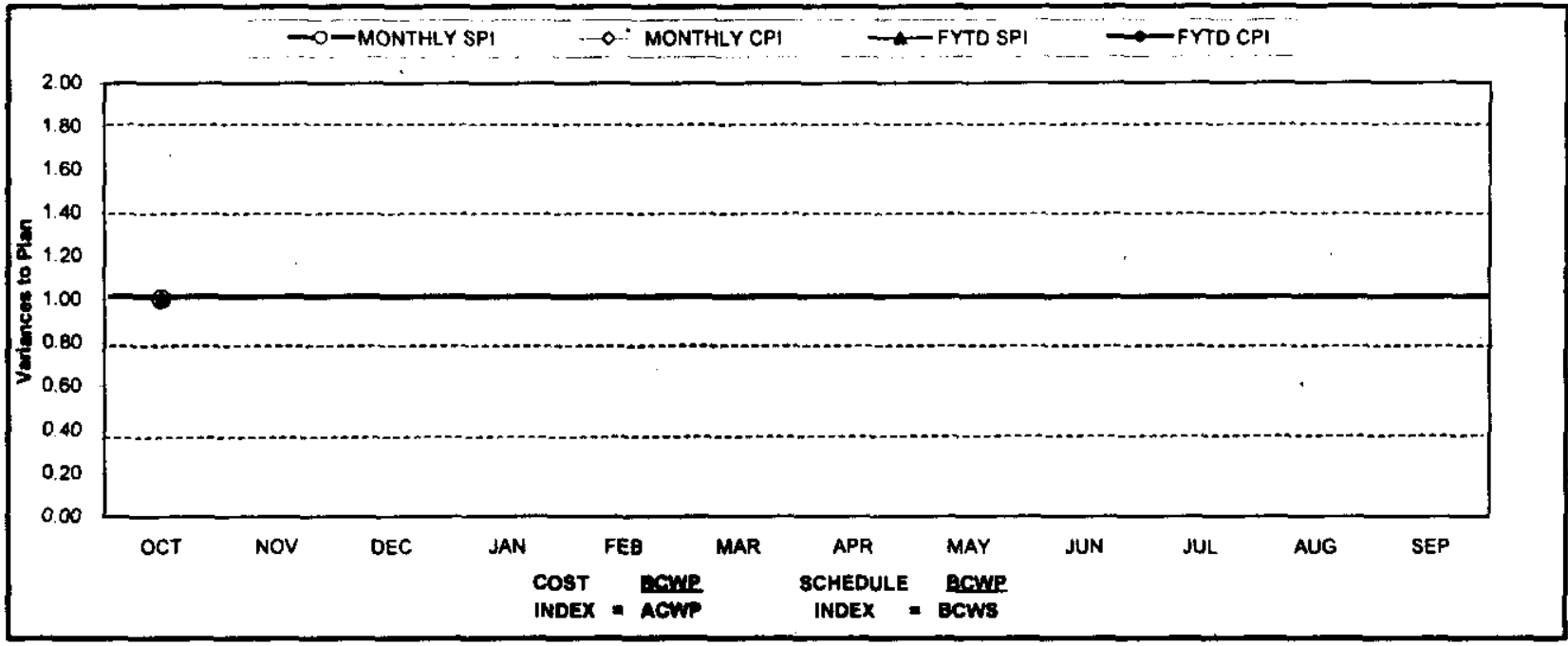

\begin{tabular}{|c|c|c|c|c|c|c|c|c|c|c|c|c|}
\hline FY 2001 & $O C T$ & Nov & DEC & JAN & FEB & MAR & APR & MAY & JUN & JUL & $A \cup G$ & SEP \\
\hline MONTHL Y SPI & 1.00 & & & & & & & & & & & \\
\hline MONTHLY CPI & 2.03 & & & & & & & & & & & \\
\hline FYTD SPI & 1.00 & & & & & & & & & & & \\
\hline FYTD CPI & 203 & & & & & & & & & & & \\
\hline MONTHLY BCWS & 5,413 & 8,866 & 7,676 & 9,048 & 7.427 & 7,900 & 8,074 & 10,065 & 7.563 & 7,544 & 9.791 & 9,430 \\
\hline MONTHLY BCWP & 5,426 & & & & & & & & & & & \\
\hline MONTHI Y ACWP & 2.671 & & & & & & & & & & & \\
\hline FYTD BCWS & 5,413 & 14,279 & 21,956 & 31.004 & $5 \quad 38,431$ & 46,330 & $5 \longdiv { 5 4 , 4 0 4 }$ & 65.069 & S 72,632 & S 80,176 & 89,967 & 99,397 \\
\hline FYTD BCWP & 5,426 & & & & & & & & & & & \\
\hline FYTD ACWP & $5 \quad 2,671$ & & & & & & & & & & & \\
\hline
\end{tabular}

\section{COST VARIANCE ANALYSIS: $(+\$ 2.8 \mathrm{M})$}

\section{WBS/PBS Title}

\subsection{1/WM03 Solid Waste Storage \& Disposal}

Description/Cause: The favorable cost variance of $\$ 1.9 \mathrm{M}$ (135 percent) is primarily due to pool billings not processed, an incorrect fee accrual, and budgeted staff supporting SNF.

Impact: No impact.

Corrective Action: The billings and fee accrual will be corrected in November.

\subsection{2/WM04 Solid Waste Treatment}

Description/Cause: The favorable cost variance of $\$ 0.4 \mathrm{M}$ (23 percent) is due to pool billings not being processed, vacancies, and TRU contracts not yet finalized.

Impact: No impact.

Corrective Action: The billings will be processed and the contracts finalized in November. The vacancies are being evaluated.

\subsubsection{1/WM05 Liquid Effluents}

Description/Cause: The favorable cost variance of $\$ 0.4 \mathrm{M}$ ( 25 percent) is a result of the pool billings not being processed, and vacancies. 
Impact: No impact.

Corrective Action: The billings will be processed in November. The vacancies are being evaluated.

\subsection{2/TP02 WESF}

Description/Cause: The favorable cost variance of $\$ 0.04 \mathrm{M}$ (6 percent) is within the established threshold.

Impact: No impact.

Corrective Action: No corrective action required.

\section{SCHEDULe VARIANCE ANALYSIS: (\$0.0M)}

\section{WBS/PBS}

1.2.1/ WM03

\section{Title}

\section{Solid Waste Storage \& Disposal}

established threshold.

Impact: No Impact.

Corrective Action: No corrective action required.

1.2.2/ WM04

Solid Waste Treatment

Description /Cause: The unfavorable schedule variance of $\$ 0.01 \mathrm{M}(0.4$ percent $)$ is within the established threshold.

Impact: No Impact.

Corrective Action: No corrective action required.

\subsubsection{1/ WM05}

Liquid Effluents

Description /Cause: The favorable schedule variance of $\$ 0.01 \mathrm{M}(0.7$ percent $)$ is within the established threshold.

Impact: No Impact.

Corrective Action: No corrective action required.

\subsection{2/ TP02}

WESF

Description /Cause: There is no schedule variance.

Impact: No Impact.

Corrective Action: No corrective action required.

\section{ISSUES}

\section{Technical Issues}

None. 


\section{DOE/Regulator/External Issues}

\section{Interim Report for Hanford Land Disposal Restrictions (LDR) for Mixed Wastes - Substantial areas of disagreement still exist between RL and Ecology on the required scope and content of the Annual LDR Submittal as delineated in the Final Determination issued by the Director of Ecology on March 29, 2000. RL is appealing certain aspects of the Ecology requirements, with formalized hearings scheduled for early in calendar year 2001.}

There are still major disagreements with Ecology over LDR reporting requirements. The most significant is the definition of "waste", as Ecology wants materials that have not yet been declared waste to be managed as waste and reported on annually. Ecology submitted "Motion for Partial Summary Judgment" on September 25, 2000, to the court in order to attempt to have RL's appeal of the Final Determination dismissed. In response, RL submitted a legal document that argued against this position. Ecology then responded with another document arguing against DOE's position. Talks are underway with Ecology on LDR and several other issues in an attempt to resolve them without litigation.

Hanford Facility (HF) RCRA Permit - The RL Regulatory Compliance Analysis Division informally proposed to Ecology that the agency incorporate lessons learned from the 222-S Laboratory Complex Part B permit application negotiations into the Central Waste Complex (CWC) and Waste Receiving and Processing (WRAP) portions of the HF Resource Conservation and Recovery Act of 1976 (RCRA) Permit. This would further delay issuance of Modification $\mathrm{E}$, but would be of great benefit to both facilities. Modification E will incorporate the CWC and the 616 Non-radioactive Dangerous Waste Storage Facility (NRDWSF) Closure Plan into the RCRA Permit.

Remote-Handled TRU Project Management Plan (PMP) - Ecology disapproved the PMP (Tri-Party Agreement milestone M-91-03) on August 14, 2000 due to the submittal not meeting the requirements set forth in Section 11.5 of the Hanford Federal Facility Agreement and Consent Order (Tri-Party Agreement). Internal meetings with RL are ongoing and meetings with Ecology occurred in mid-September; a path-forward for resolution of Ecology's concerns with the PMP is being developed based on these discussions.

Impacts of Waste Management PEIS and ROD - The Waste Management Programmatic Environmental Impact Statement (PEIS) was issued on February 25, 2000. The Records of Decision (ROD) for low-level waste and mixed low-level waste will affect Hanford's disposal role for the Complex and may have a significant impact on disposal volumes and rates at Hanford. DOE-HQ and Ecology negotiations continue; impacts depend upon the results of these negotiations. 
Baseline Change Requests Currently in Process

$(\$ 000)$

\begin{tabular}{|c|c|c|c|c|c|c|c|c|c|}
\hline $\begin{array}{l}\text { PROJECT } \\
\text { CHANGE } \\
\text { NUMBER }\end{array}$ & $\begin{array}{l}\text { DATE } \\
\text { ORIGIN. }\end{array}$ & BCR TITLE & $\begin{array}{c}\text { COST } \\
\text { IMPACT } \\
\$ 000\end{array}$ & $\begin{array}{l}S \\
C \\
H\end{array}$ & $\begin{array}{l}\mathrm{T} \\
\mathrm{E} \\
\mathrm{C} \\
\mathrm{H}\end{array}$ & $\begin{array}{l}\text { DATE } \\
\text { TO CCB }\end{array}$ & $\begin{array}{c}\text { CCB } \\
\text { APR'VD }\end{array}$ & $\begin{array}{c}\text { RL } \\
\text { APR'VD }\end{array}$ & $\begin{array}{l}\text { CURRENT } \\
\text { STATUS }\end{array}$ \\
\hline WM-2000-015 & $7 / 26 / 00$ & WMP FY 2001 MYWP Revision & So & & & $8 / 31 / 00$ & $9 / 25 / 00$ & & At DOE-RL \\
\hline FH-2001-001 & $9 / 12 / 00$ & Base Ops Reduction for PHMC Projects & $-\$ 5,036$ & & $\mathrm{x}$ & & & & At DOE-RL \\
\hline FH-2001-002 & $9 / 25 / 00$ & FY2001 Fee Reduction to $90 \%$ & $-\$ 740$ & & & & & & At DOE-RL \\
\hline FH-2001-003 & $9 / 25 / 00$ & $\begin{array}{l}\text { FY2001 Addition of High Priority } \\
\text { Workscope }\end{array}$ & $\$ 5,639$ & & $\mathrm{x}$ & & & & At DOE-RL \\
\hline \multicolumn{10}{|c|}{ ADVANCE WORK AUTHORIZATIONS } \\
\hline WMP-AWA-001 & $10 / 18 / 00$ & FY2001 LDR scope & & & & & $10 / 18 / 00$ & $10 / 18 / 00$ & \\
\hline
\end{tabular}

Milestone ACHievement

Green

\begin{tabular}{|c|c|c|c|c|c|c|c|c|}
\hline \multirow[b]{2}{*}{ MILESTONE TYPE } & \multicolumn{4}{|c|}{ FISCAL YEAR-TO-DATE } & \multicolumn{3}{|c|}{ REMAINING SCHEDULED } & \multirow[b]{2}{*}{$\begin{array}{l}\text { TOTAL } \\
\text { FY } 2001\end{array}$} \\
\hline & $\begin{array}{c}\text { Completed } \\
\text { Earty }\end{array}$ & $\begin{array}{c}\text { Completed } \\
\text { On Schedule }\end{array}$ & $\begin{array}{c}\text { Completed } \\
\text { Late }\end{array}$ & Overdue & $\begin{array}{c}\text { Forecast } \\
\text { Eary }\end{array}$ & $\begin{array}{c}\text { Forecast On } \\
\text { Schedule }\end{array}$ & Forecast Late & \\
\hline Enforceable Agreement & 0 & 0 & 0 & 0 & 0 & 3 & 0 & \\
\hline DOE-HQ & 0 & 0 & 0 & $\underline{0}$ & 0 & 0 & 0 & \\
\hline $\mathrm{RL}$ & 0 & 0 & 0 & 0 & 0 & 1 & 0 & 1 \\
\hline Total Project & 0 & 0 & 0 & 0 & 0 & 4 & 0 & 4 \\
\hline
\end{tabular}

Only TPA/EA milestones and all FY2001 overdue and forecast late milestones are addressed in this report. Milestones overdue are deleted from the Milestone Exception Report once they are completed. The following chart summarizes the FY2001TPA/EA milestone achievement and a Milestone Exception Report follows. The last milestone table summarizes the first six months of FY 2002 TPA/EA milestones. 
PHMC Environmental Management Performance Report - December 2000

Section B: I - Waste Management

FY 2001 Tri-Party Agreement / EA Milestones

\begin{tabular}{|l|l|c|}
\hline \multicolumn{1}{|c|}{ Number } & \multicolumn{1}{|c|}{ Milestone Title } & Status \\
\hline $\begin{array}{l}\text { M-91-11-T01 } \\
\text { (A2G-01-103) }\end{array}$ & Submit LLWM Facility ES/FDC to Ecology & Due 12/31/00 \\
\hline $\begin{array}{l}\text { M-91-12 } \\
\text { (A2G-01-104) }\end{array}$ & Initiate Thermal Treatment of CH-LLMW & Due 12/31/00 \\
\hline $\begin{array}{l}\text { M-91-13 } \\
\text { (A1C-01-001) }\end{array}$ & Initiate Disposal of CH-LLWM & Due 06/30/01 \\
\hline $\begin{array}{l}\text { M-26-05H } \\
\text { (WMH-00-006) }\end{array}$ & $\begin{array}{l}\text { Prep Biennial Tritium Treatment Technology Evaluation } \\
\text { report }\end{array}$ & Due 08/31/01. \\
\hline
\end{tabular}

DNFSB Commitments

Nothing to report at this time.

\section{MILESTONE EXCEPTION REPORT}

\begin{tabular}{|c|c|}
\hline Number/NBS Level & Milestone Title \\
\hline
\end{tabular}

\section{OVERDUe - 0}

FORECAST LATE - 0

FY 1999 OVERDUE - 1

TRP-98-709 RL - Complete Hot Cell Deactivation 03/31/99 03/30/01

\subsubsection{WESF Facility (A-E)}

Cause: This milestone is not complete due to not being supported at the current funding level. Impact: No overall impact is expected.

Corrective Action: Return-on-Investment (ROI) funding has been identified for this work scope and a new forecasted completion date of March 30, 2001 established.

FY 2002 Tri-Party Agreement / EA Milestones

\begin{tabular}{|c|c|c|}
\hline Number & Milestone Title & Status \\
\hline & Nothing to report at this time. & \\
\hline
\end{tabular}

DNFSB Commitments

Nothing to report at this time. 


\section{Performance Objectives}

Performance Objectives have not been finalized and are to be considered as "preliminary" at this time.

\section{TRU CERTIFICATION FOR SHIPPING}
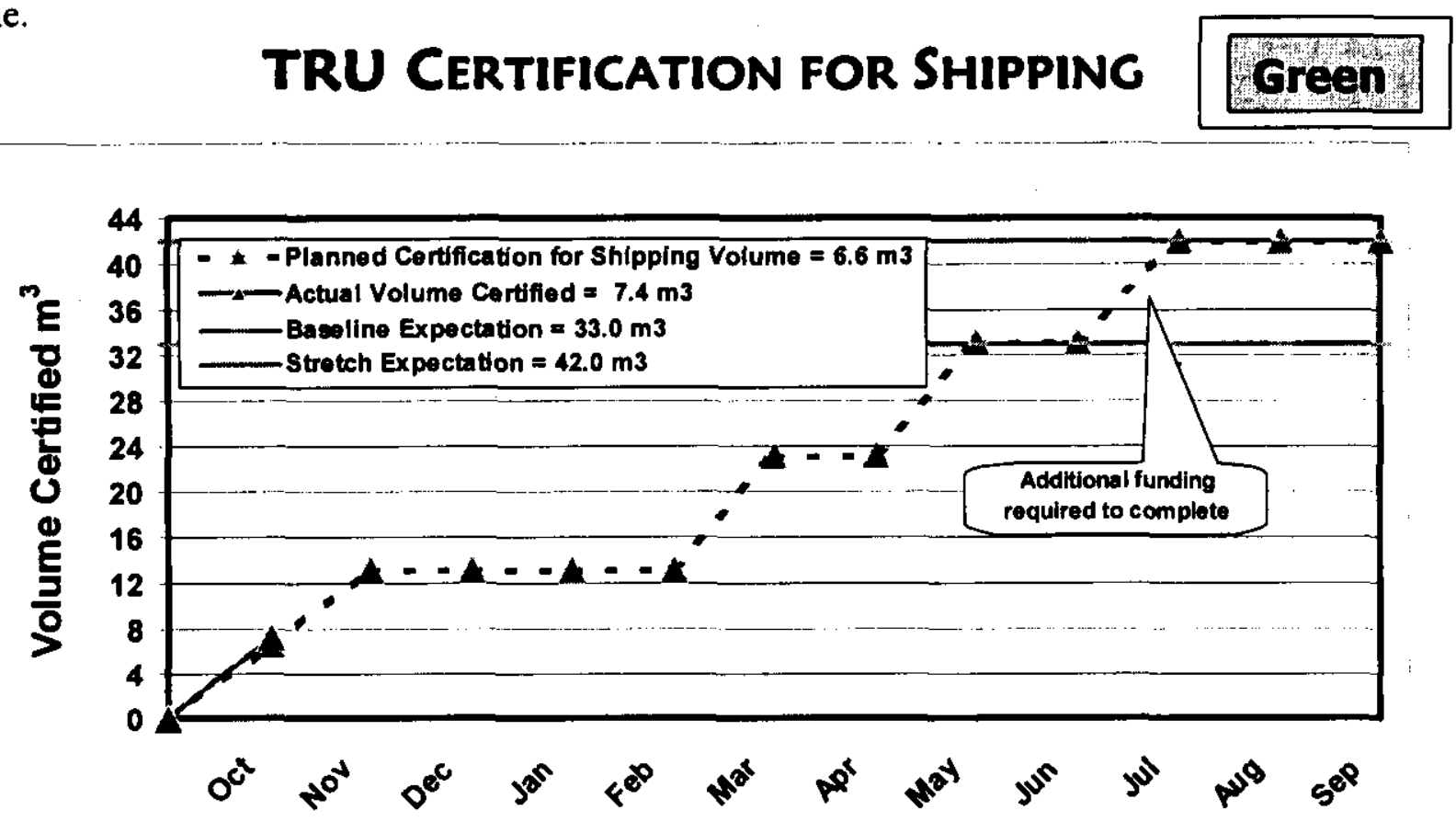

Action Plans: On track and currently ahead of schedule. $7.4 \mathrm{~m}^{3}$ certified through October 2000 .

\section{STORED SUSPECT TRU RETRIEVAL}
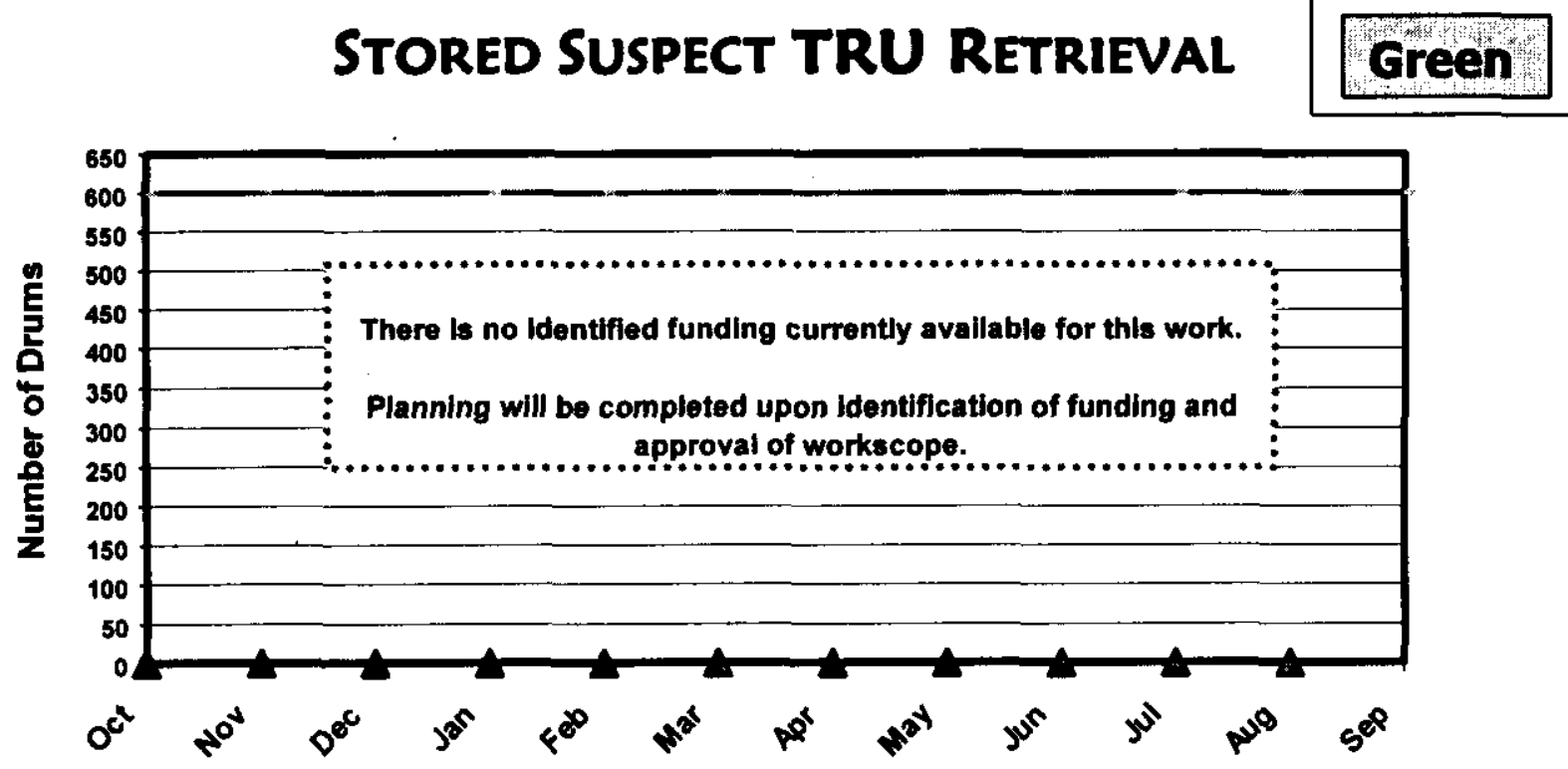

\footnotetext{
$\cdots$ - Drum Removal \& Staging - Plan $=600$

- Field Asesy - Plan =

- Assign Waste Designation - Plan = 600

Stretch Expectation = 600 Drums
}

$$
\begin{aligned}
& \text { Drum Removal \& Staging - Actual = } \\
& - \text { Field Assay - Actual = } \\
& \text { Assign Waste Designation - Actual * }
\end{aligned}
$$

Action Plans: Working to identify funding and obtain approval of work scope. 


\section{Liguid Waste Processing}

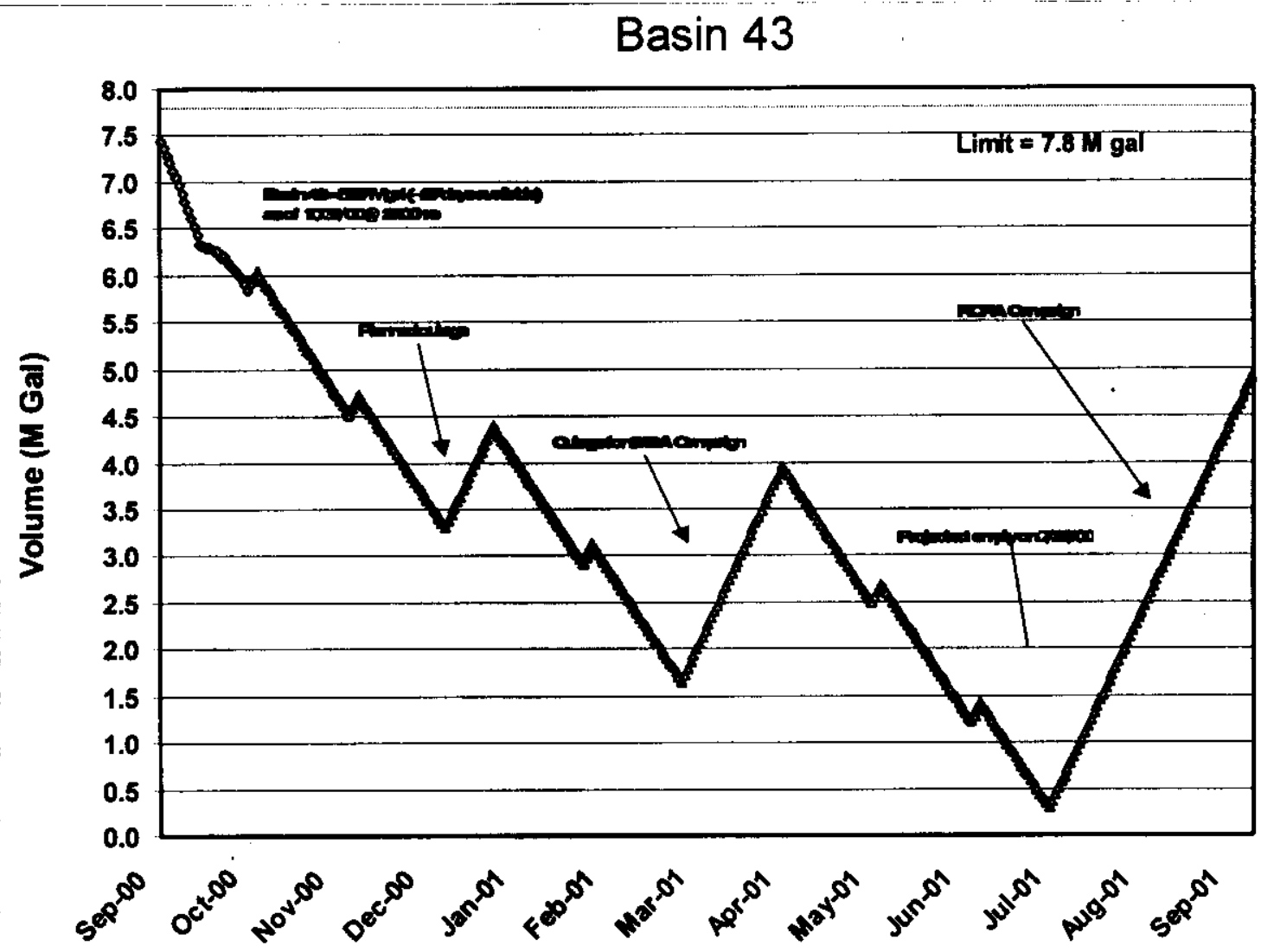

Action Plans: On track. At the end of October, $1.82 \mathrm{M}$ gallons of space available in Basin \#43.

\section{UP-1 GROUNDWATER TREATMENT}
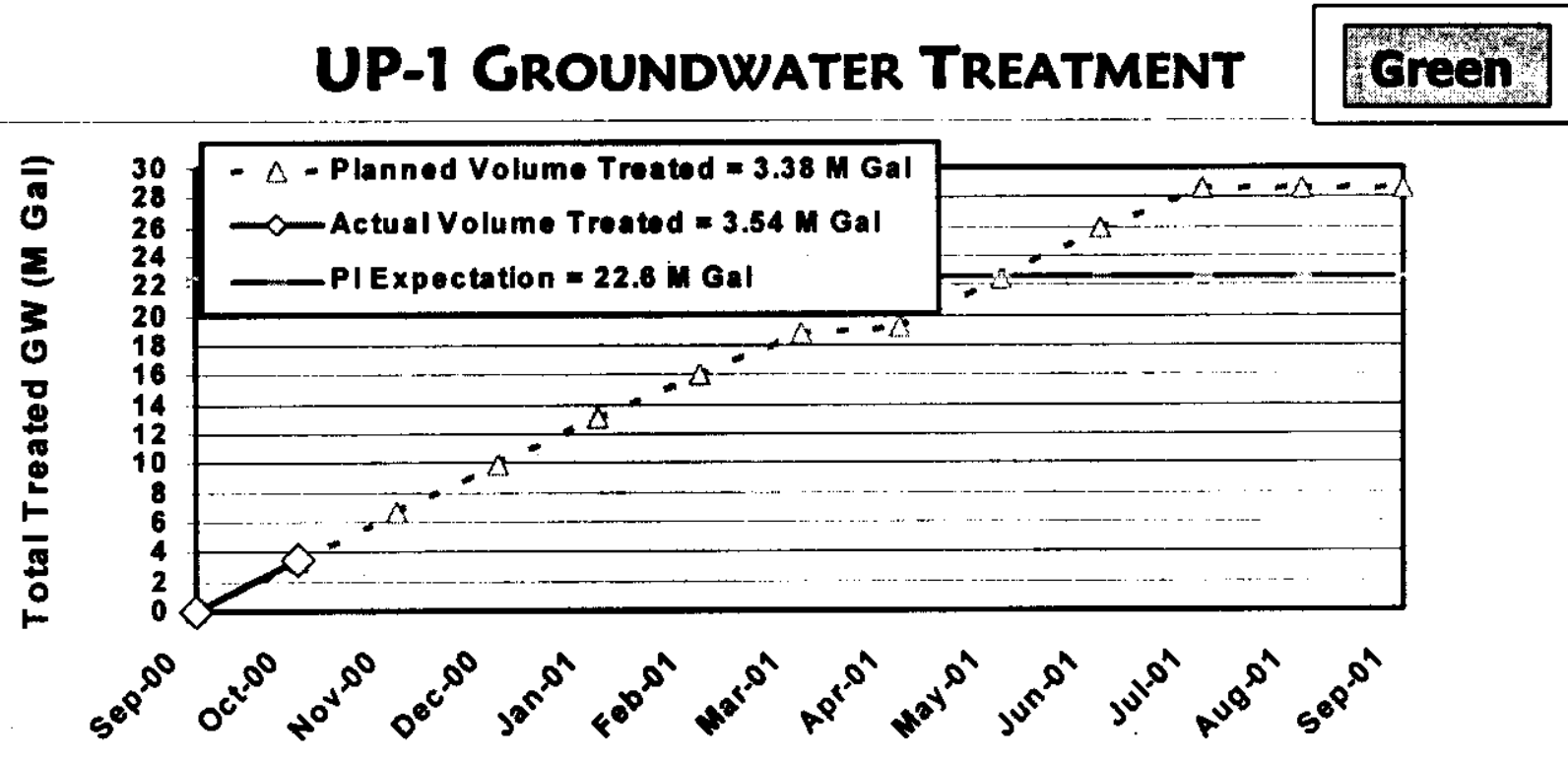

Action Plans: On track. Through October processed $3.54 \mathrm{M}$ gallons. 


\section{T Plant Deck Clearing}

\section{Planned Clear Decks $=0 \%$}

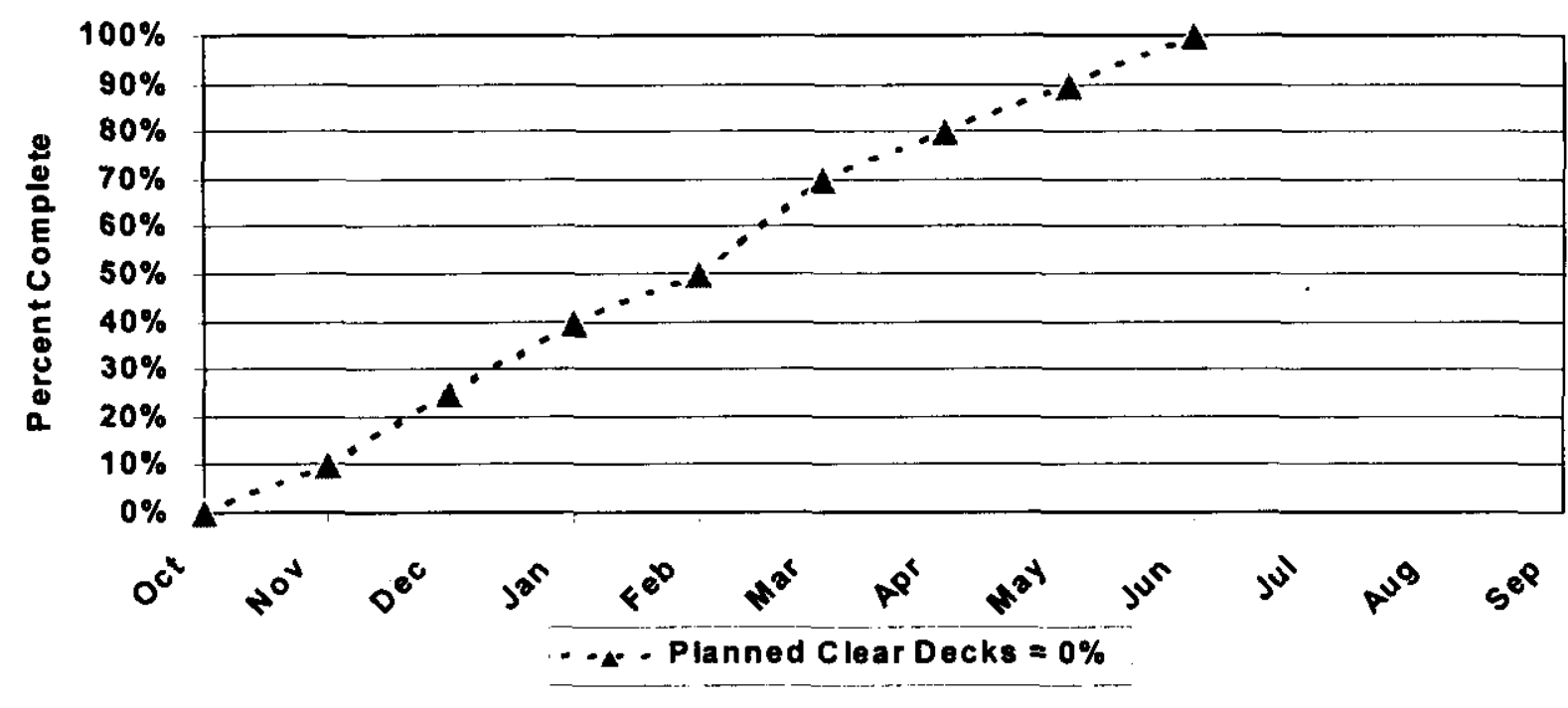

Action Plans: On track. Deck clearing will resume in November.

\section{T Plant Cell Inspection}

Planned Cell Inspection

\begin{tabular}{l}
0 \\
0 \\
0 \\
0 \\
0 \\
0 \\
0 \\
0 \\
0 \\
0 \\
0 \\
\hline \\
0 \\
0 \\
0 \\
0
\end{tabular}

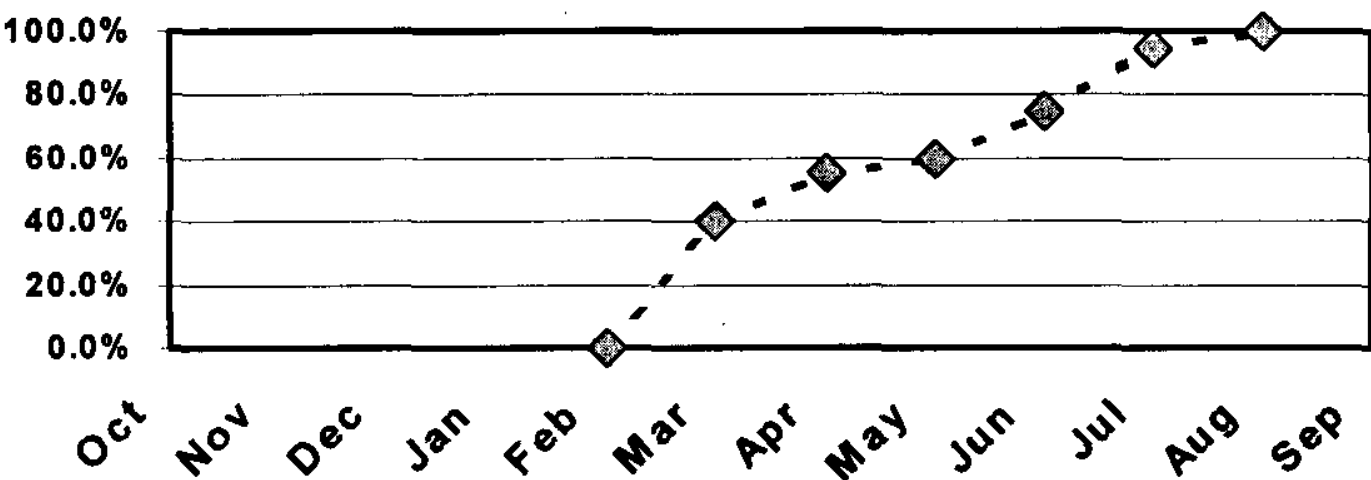

- Planned Cell Inspection

Action Plans: On track. Cell inspection tied to deck clearing will resume in November. 


\section{T Plant Tower Removal}

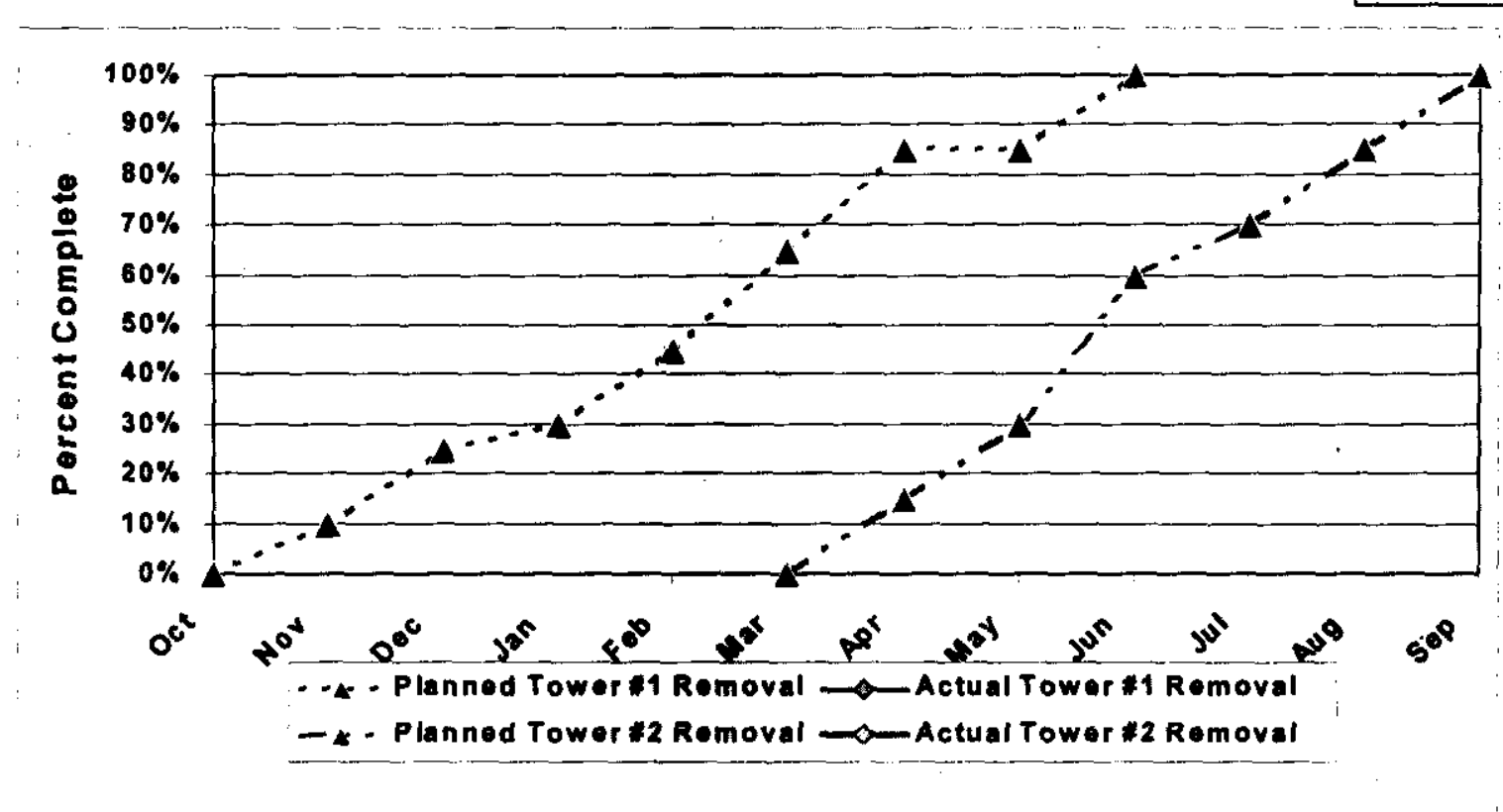

Action Plans: On track.

\section{KEY INTEGRATION ACTIVITIES}

- Preparing T Plant to receive Spent Nuclear Fuel K Basin sludge.

- Issuance of Records of Decision for Low-Level Waste (LLW) and Mixed Low-Level Waste (MLLW) is expected to affect Hanford's role in disposing of waste from other sites.

Working with DOE-RL, DOE-HQ and other Sites to develop and define Hanford's role as one of the identified LLW/MLLW disposal sites for the Complex. A comprehensive strategy will be developed for the DOE complex low-level waste with the Nevada Test Site by the end of FY 2001.

- Support continued UP-1 Groundwater treatment.

- Support River Corridor Project in cleanup and removal of waste from 324 and 327 buildings.

- Support the ORP Waste Treatment Plant.

- Continue working with PNNL, EM 50 and Mixed Waste Focus Area (MWFA) to obtain funding in support of mixed waste processing (M-91 Facility Project).

- Continue to work with DOE- RL, -Oakland, and -Ohio to support resolution of TRU small quantity site disposition issues.

- Support visits from both the DOE-Idaho Program Office and the Office of the Inspector General in regards to opportunities for treatment/disposal of Idaho National Engineering Environment Laboratory (INEEL) wastes at Hanford. 


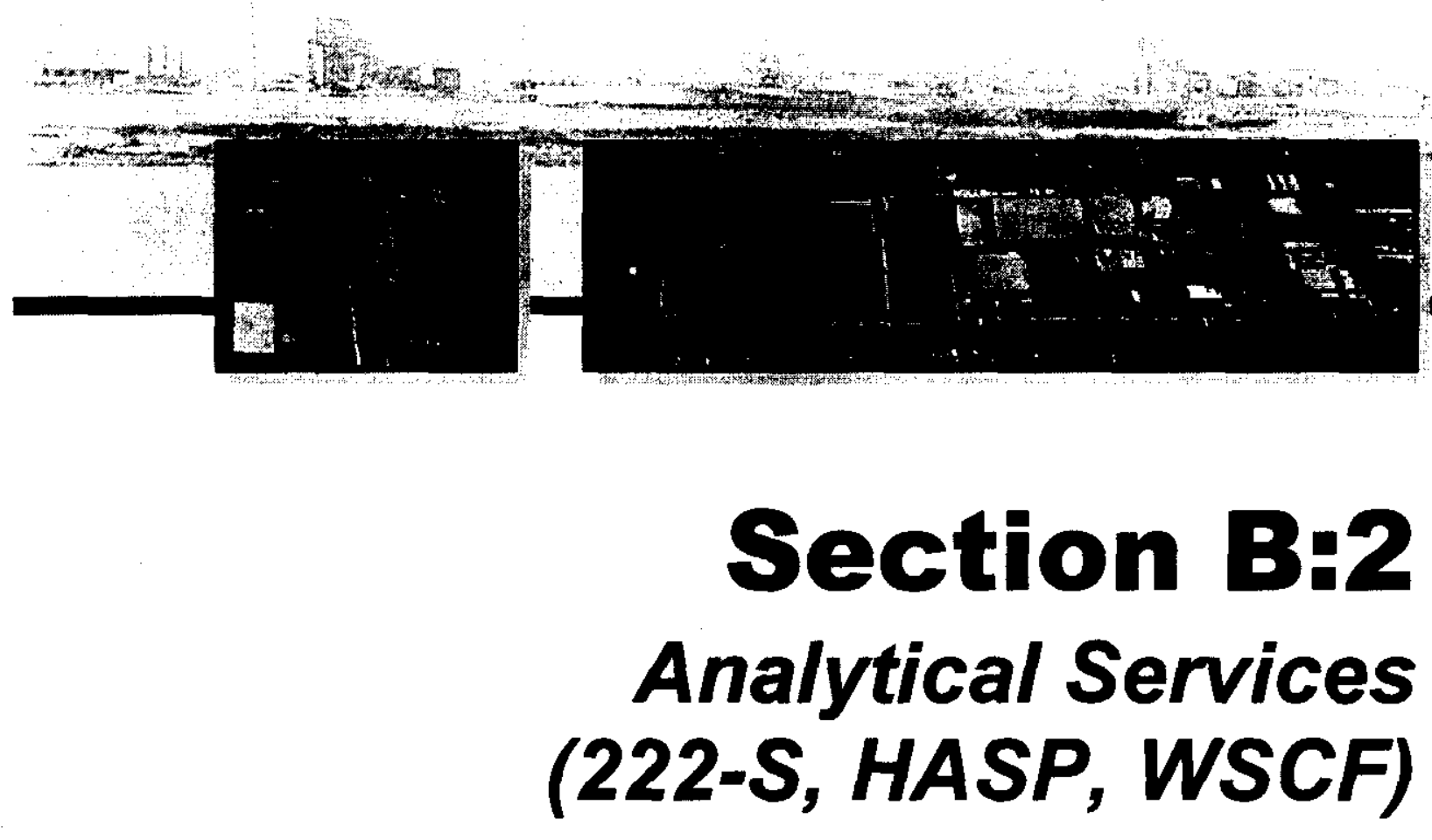

PROJECT MANAGERS S.H. Wisness, RL (509) 373-9337

D.L. Renberger, FH (509) 372-0877 


\section{SUMMARY}

The Analytical Services (AS) Project [222-S, Hanford Analytical Services Program (HASP), Waste Sampling and Characterization Facility (WSCF)] consists of Analytical Services, PBS WM06, WBS 1.2.4.

NOTE: Unless otherwise noted, the Safety, Conduct of Operations, Milestone Achievement, and Cost/Schedule data contained herein is as of October 31, 2000. Other data is updated as noted.

\section{ACCOMPLISHMENTS}

- Processed a total of 0.8 Analytical Equivalency Unit (AEUs) (versus 0.2 AEUs planned) at the 222-S Laboratory in October in support of the River Protection Project (RPP) (TWRS) tank characterization program. Production through November 17, 2000 is 1.3 AEUs. A letter has been released from Office of River Protection (ORP) allowing a waiver for analytical waste generated at 222-S from Polychlorinated Biphenyl (PCB) acceptance criteria until the end of December 2000.

- Performed 2,782 analyses through November 2000 at WSCF for a wide variety of customers.

- The State of Washington Department of Ecology (Ecology) completed an assessment of WSCF in November. The closeout meeting was very positive; Ecology complimented the facility for its professional support of the assessment. In addition, Ecology also complimented the Laboratory Information Management System (LIMS) and the way priorities are communicated to the bench chemists. No negative observations were made.

- Eight pollution prevention projects from the 222-S Laboratory are being nominated in four categories for pollution prevention awards to the Department of Energy at the RL level. General project descriptions include: reduction of glassware in the laboratory for sample preparation, education and outreach through the aluminum can recycling for Christmas families and the Safety Expo, recycling laboratory standards materials for research use at Pacific Northwest National Laboratory (PNNL), and implementation of laboratory waste minimization methods for environmental impact through return on investment and legal agreements. RL will submit projects that are awarded at the national level for the White House "Closing the Circle" award.

- Dr. Steven Bakhtiar of Analytical Services chaired the $46^{\text {th }}$ Annual Bioassay, Analytical, and Environmental Radiochemistry (BAER) Conference in Seattle in November 2000.

- Consent Agreement and Final Order RCRA-10-99-0106, which addressed drum storage in the 200 East Pipe Yard, was issued to RL on October 16, 2000 and committed RL to the completion of two Supplemental Environmental Projects (SEP). SEP \#2 is a pollution prevention/reduction project to develop and implement new analytical procedures that would eliminate sodium interferences for certain laboratory methods used at Hanford for tank waste. Analytical Services initiated work on SEP \#2 in advance of formal RL authorization, but within 30 calendar days of receipt as required by the Final Order. RL is aware of AS action and is working to provide formal direction and funding. 


\section{SAFETY}

In October, there were no OSHA recordable cases, no Restricted Workday Cases, and two First Aid Cases. It was the first month since April 2000 with no OSHA recordable cases. The OSHA recordable case rate increased, with two of the past three months at two standard deviations above average. The DOE Safety Cost Index was also rebaselined upwards due to recent increasing trends.

Analytical Services continues to focus on ergonomic issues, and has brought in Hanford Environmental Health Foundation (HEHF) expertise to 222-S to assist in ergonomic evaluations and Development Staff to revise sample cask handling methods. It is anticipated that this action will improve the Case Rates.

Two chemical technologists from the 222-S Laboratory Analytical Services team made a presentation to the President's Zero Accident Council (PZAC) on the new-shielded carrier design, including a demonstration with a prototype. The presentation was well received. 
PHMC Environmental Management Performance Report-December 2000

Section B: 2 - Analytical Services (222-S, HASP, WSCF)

12 Lost Away Workday Case Rate

Cases per 200,000 hours

10

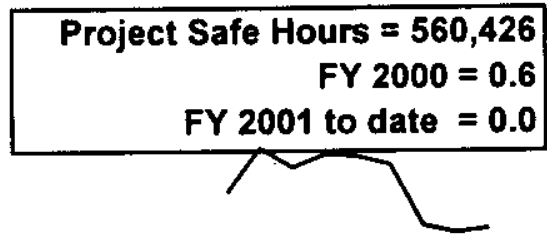

8

Average $=1.4$

6

$1,600,000$ hours without a Lost Away Work Day Case (Oct 96 - Apr 99)

4

2

0

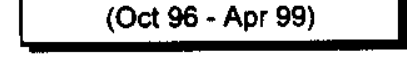

(Apr 99 - Nov 99)
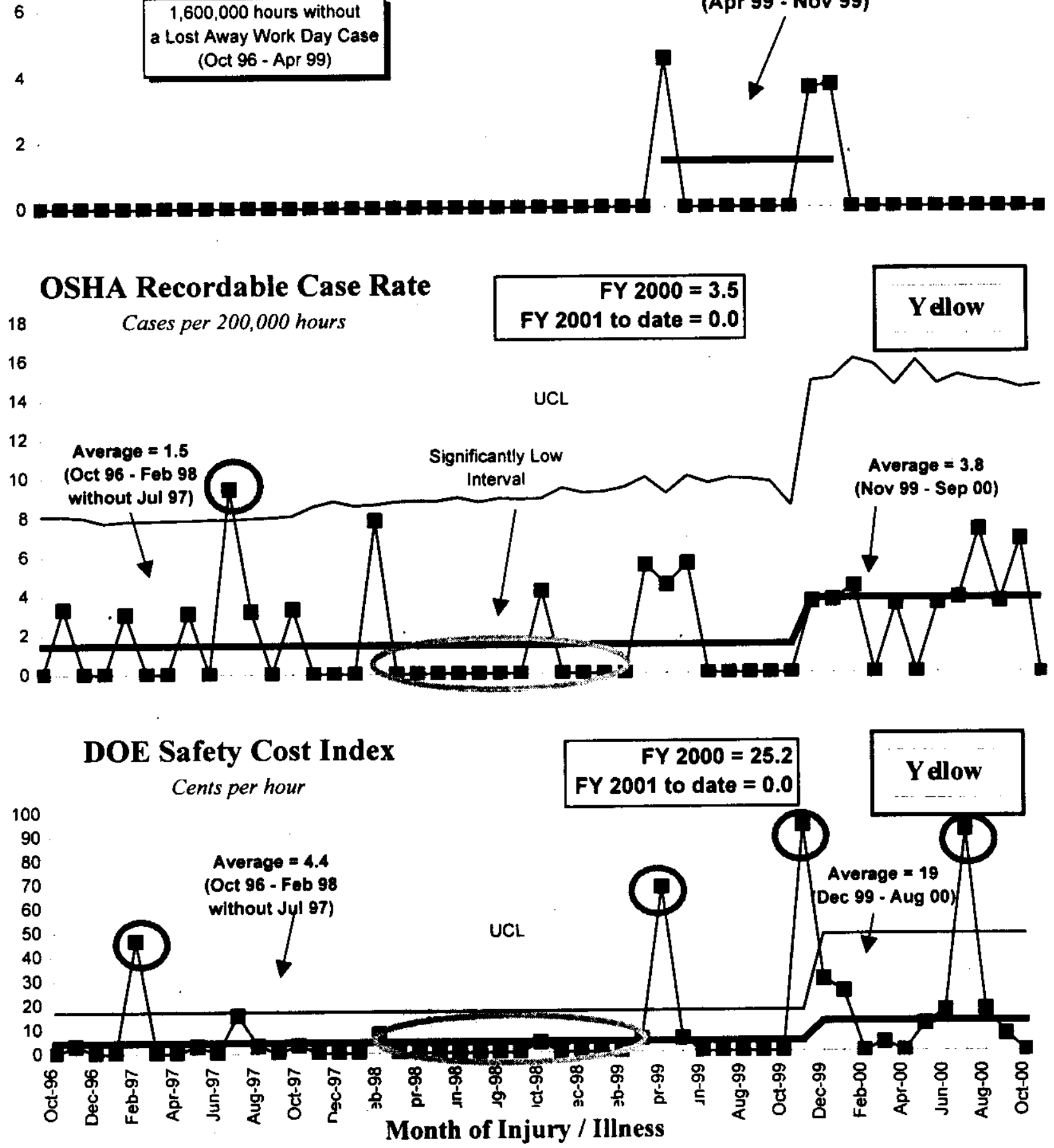


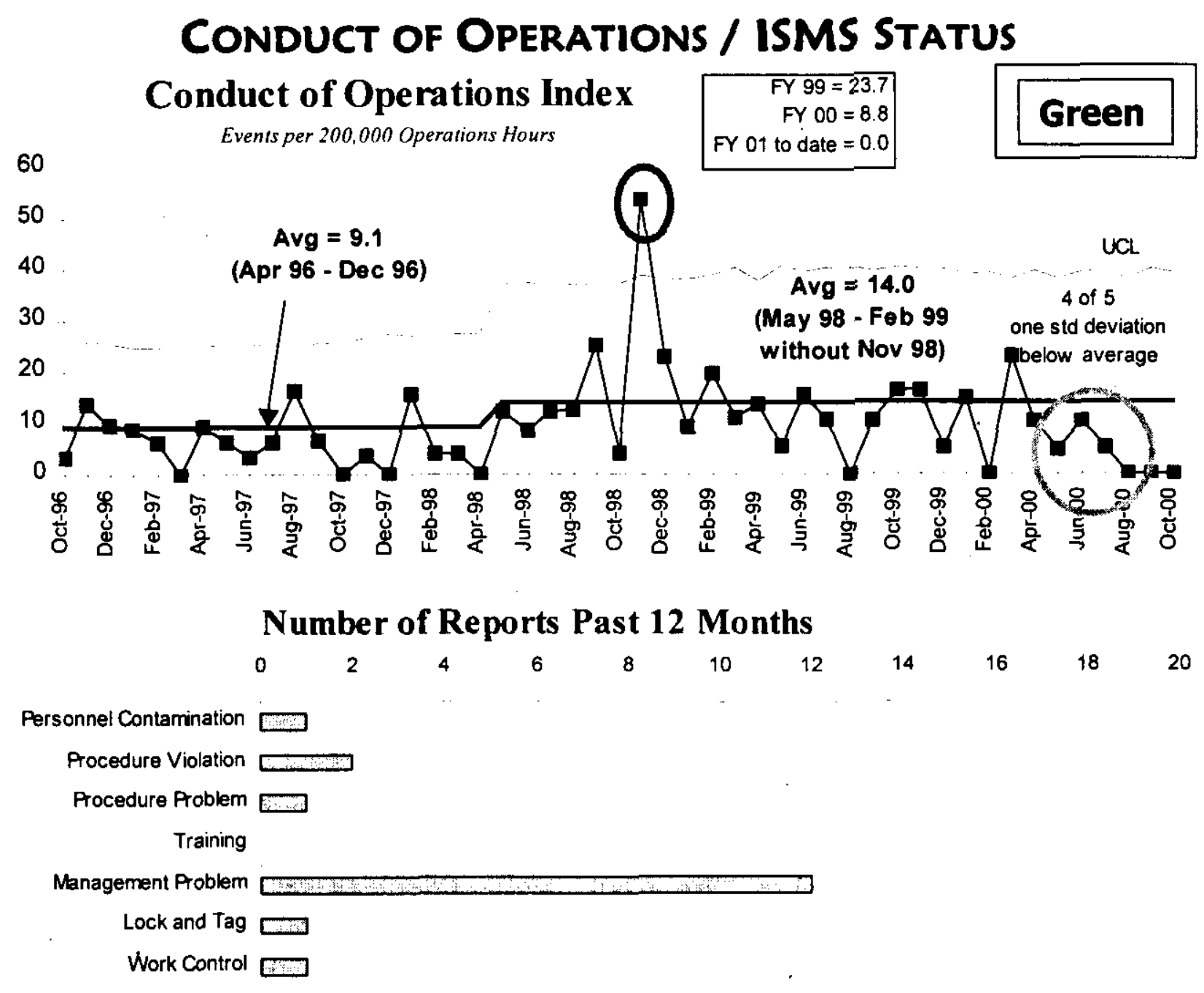

\section{ISMS STATUS}

Analytical Services ISMS status is included in the Waste Management Project Section of this report.

\section{BREAKTHROUGHS}

Nothing to report at this time.

\section{OPPORTUNITIES FOR IMPROVEMENT}

Nothing to report at this time. 


\section{UPCOMINC ACTIVITIES}

- WIPP Waste Shipments - Continue to support the production goal of headspace analysis in support of waste shipments to WIPP. Continued discussions with INEEL regarding possible support to the INEEL WIPP program.

- ORP Waste Treatment Plant - Support DOE-RL and ORP efforts to evaluate options for long-term high-activity laboratory support to the Site cleanup mission (i.e. 222-S, WTP laboratory, a new laboratory, etc.).

- 222-S RCRA Part B Application - Continue to support development of Modification F (which includes 222-S Part B application) of the Hanford Facility (HF) RCRA Permit review. Modification $F$ will be issued after issuance of Modification $E$ (which includes WRAP and CWC).

- PCB Management - Continue to work with RL and ORP on PCB management and regulatory issues.

\section{Cost Performance (\$M):}

\begin{tabular}{|l|c|c|c|}
\hline & BCWP & ACWP & VARIANCE \\
\hline Analytical Services & $\$ 2.0$ & $\$ 2.9$ & $-\$ 1.0^{*}$ \\
\hline
\end{tabular}

*Rounding

The $\$ 1.0$ million (49 percent) unfavorable cost variance is due to the accrual of FY 2000 fee without a corresponding reversal. The unfavorable variance is partially offset by underruns due to costing delays normally associated with fiscal year startup (lagging contract costs, reversal of FY 2000 yearend accruals, delays in billings of assessments). The actual cost variance for October is a favorable $\$ 0.4 \mathrm{M}$.

\section{Schedule Performance (\$M):}

\begin{tabular}{|l|c|c|c|}
\hline & BCWP & BCWS & VARIANCE \\
\hline Analytical Services & $\$ 2.0$ & $\$ 2.0$ & $\$ 0.0$ \\
\hline
\end{tabular}

There is no schedule variance. 


\section{FY 2001 Cost/Schedule Performance - All Fund Types Cumulative to Date Status - $(\$ 000)$}

FYTD

By PBS

WBS 1.2.4 Analytical

PBS WM06 Services

Total

\begin{tabular}{|c|c|c|c|c|c|c|c|}
\hline & & & & & & & reen \\
\hline BCWS & BCWP & ACWP & sv & $\%$ & CV & $\%$ & PEM \\
\hline$\$ 2,000$ & $\$ 1,975$ & $\$ 2,948$ & $\$(25)$ & $-1 \%$ & $\$(973)$ & $-49 \%$ & $\$ 32,139$ \\
\hline$\$ 2,000$ & $\$ 1,975$ & $\$ 2,948$ & $\$(25)$ & $-1 \%$ & $\$(973)$ & $-49 \%$ & $\$ 32,139$ \\
\hline
\end{tabular}

Note: RL-Directed costs (steam and laundry) are included.

\section{Cost/SCHedule Performance INDices (MONTHLY AND FYTD)}

\section{Green}

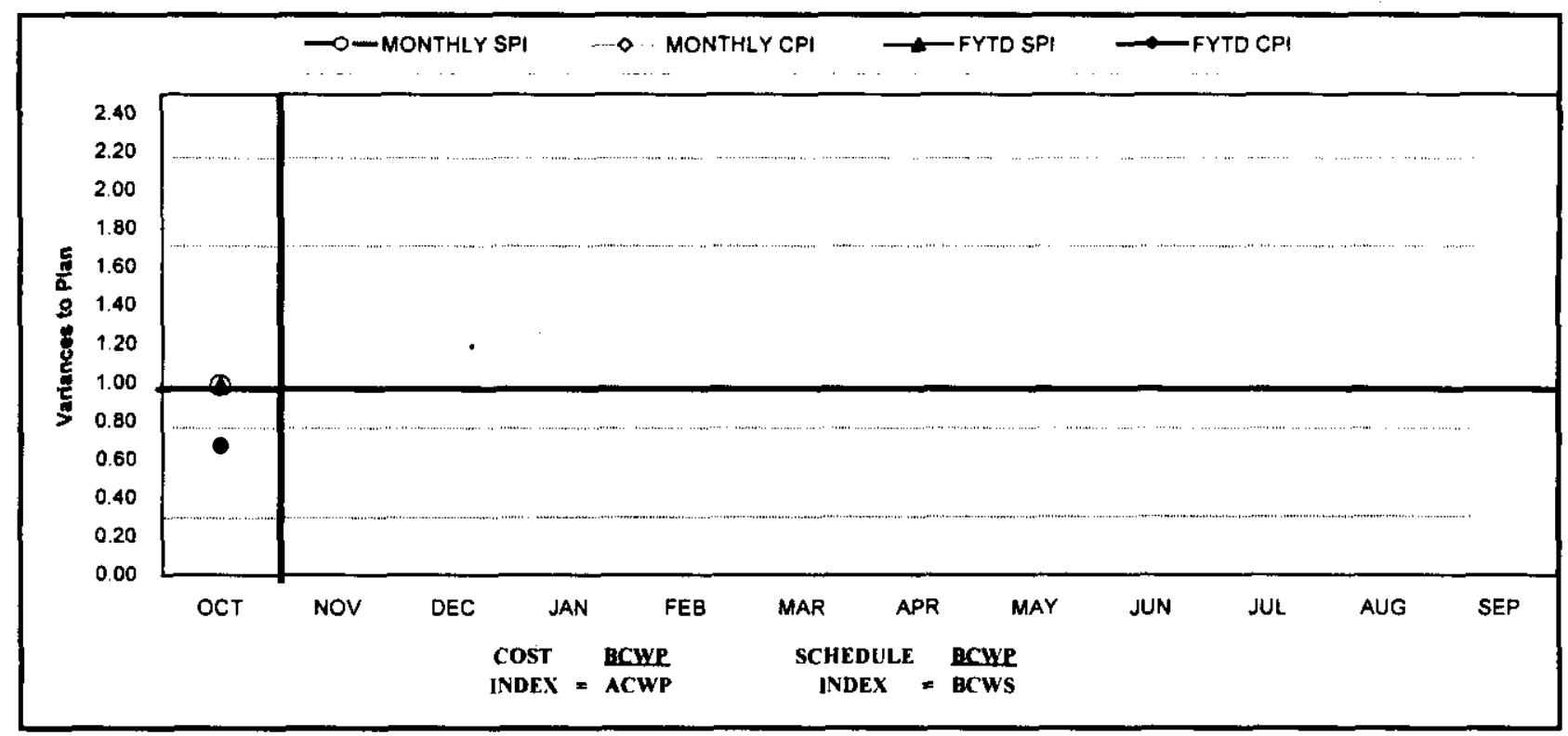

\begin{tabular}{|c|c|c|c|c|c|c|c|c|c|c|c|c|}
\hline FY 2001 & OCT & NOV & DEC & JAN & FEB & MAR & $\overline{\mathbf{A P R}}$ & MAY & JUN & JUL & AlIG & SEP \\
\hline MONTHLY SPI & 0.99 & & & & & & & & & & & \\
\hline MONTHLY CPI & 0.67 & & & & & & & & & & & \\
\hline FYTD SPI & $0 . \overline{99}$ & & & & & & & & & & & \\
\hline FYTD CPI & 0.67 & & & & & & & & & & & \\
\hline MONTHLY BCWS & $\$ 2.000$ & $\$ 3.098$ & $\$ 2.599$ & $\$ 2,772$ & $\$ 2,316$ & $\$ 2.549$ & $\$ 2,511$ & $\$ 3.046$ & $\$ 2.324$ & $\$ 2.306$ & $\$ 3,030$ & $\$ 3.588$ \\
\hline MONTHLY BCWP & $\$ 1,975$ & & & & & & & & & & & \\
\hline MONTHLY ACWP & $\$ 2.948$ & & & & & & & & & & & \\
\hline FYTD BCWS & $\$ 2.000$ & $\$ 5,098$ & $\$ 7,697$ & $\$ 10.469$ & $\$ 12.785$ & $\$ 15,334$ & $\$ 17.845$ & $\$ 20.890$ & $\$ 23.214$ & $\$ 25.520$ & $\$ 28.551$ & $\$ 32,139$ \\
\hline FYTD BCWP & $\$ 1.975$ & & & & & & & & & & & \\
\hline FYTD ACWP & $\$ 2.948$ & & & & & & & & & & & \\
\hline
\end{tabular}




\section{COST VARIANCE ANALYSIS: (-\$1.0M)}

WBS/PBS Title

\subsection{4/WM06 Analytical Services}

Description/Cause: The unfavorable cost variance of $\$ 1.0$ million (49 percent) is due to the accrual of FY 2000 fee without a corresponding reversal. The unfavorable variance is partially offset by underruns due to costing delays normally associated with fiscal year startup (lagging contract costs, reversal of FY 2000 yearend accruals, delays in billings of assessments). The true cost variance for October is a favorable $\$ 0.4 \mathrm{M}$.

Impact: None.

Corrective Action: None required.

\section{SCHEDULE VARIANCE ANALYSIS: (\$0.0M)}

$\underline{\text { WBS/PBS }}$

1.2.4/WM06

Description /Cause: None.

Impact: None.

Corrective Action: None required.
Title

\section{Analytical Services}

\section{ISSUES}

\section{Technical Issues}

Nothing to report at this time.

\section{DOE/Regulator/External Issues}

Polychlorinated Biphenyls (PCBs) Management - Analytical Services participated in a PCB workshop with EPA, Ecology, DOE, and contractor personnel in August 2000, to discuss management of PCBs at Hanford. The primary topics of discussion dealt with the consequences of managing tank farms waste as Toxic Substance Control Act (TSCA) regulated, the anticipated path-forward, and the associated impacts to interrelated facilities. EPA has recognized the concern with implementation of TSCA in conjunction with Hazardous Waste and Radioactive Waste requirements in a laboratory setting. EPA has requested an alternate management strategy for Hanford Analytical Laboratories. Analytical Services is working with PNNL to develop this strategy. 
PHMC Environmental Management Performance Report - December 2000

Section B: 2-Analytical Services (222-S, HASP, WSCF)

\section{Baseline Change Requests Currently in Process (\$000)}

\begin{tabular}{|c|c|c|c|c|c|c|c|c|c|}
\hline $\begin{array}{l}\text { PROJECT } \\
\text { CHANGE } \\
\text { NUMBER }\end{array}$ & $\begin{array}{l}\text { DATE } \\
\text { ORIGIN. }\end{array}$ & BCR TITLE & $\begin{array}{c}\text { COST } \\
\text { IMPACT } \\
\text { S000 } \\
\end{array}$ & $\begin{array}{l}\mathbf{s} \\
\mathbf{c} \\
\mathbf{H}\end{array}$ & $\begin{array}{l}\mathbf{E} \\
\mathbf{C} \\
\mathbf{H}\end{array}$ & $\begin{array}{c}\text { DATE TO } \\
\text { CCB } \\
\end{array}$ & $\begin{array}{c}\text { CCB } \\
\text { APR'VD } \\
\end{array}$ & RL APR'VD & $\begin{array}{c}\text { CURRENT } \\
\text { STATUS }\end{array}$ \\
\hline FH-2001-001 & $9 / 12 / 00$ & $\begin{array}{l}\text { Base Ops Reduction for PHMC } \\
\text { Projects }\end{array}$ & $-\$ 610$ & & $\mathbf{x}$ & & $09 / 13 / 00$ & & At DOE-RL \\
\hline FH-2001-002 & $9 / 25 / 00$ & FY2001 Fee Reduction to $90 \%$ & $-\$ 190$ & & & & $09 / 13 / 00$ & & At DOE-RL \\
\hline \multicolumn{10}{|c|}{ ADVANCE WORK AUTHORIZATIONS } \\
\hline & & Nothing to report at this time. & & & & & & $\cdot$ & \\
\hline
\end{tabular}

\section{Milestone ACHIEvement}

\section{Green}

\begin{tabular}{|r|r|r|r|r|r|r|r|r|}
\hline & \multicolumn{3}{|c|}{ FISCAL YEAR-TO-DATE } & \multicolumn{2}{c|}{ REMAINING SCHEDULED } & TOT AL \\
\cline { 2 - 9 } MILESTONE TYPE & $\begin{array}{c}\text { Completed } \\
\text { Early }\end{array}$ & $\begin{array}{c}\text { Completed } \\
\text { On Schedule }\end{array}$ & $\begin{array}{c}\text { Completed } \\
\text { Late }\end{array}$ & Overdue & $\begin{array}{c}\text { Forecast } \\
\text { Early }\end{array}$ & $\begin{array}{c}\text { Forecast } \\
\text { On } \\
\text { Schedule }\end{array}$ & $\begin{array}{c}\text { Forecast } \\
\text { Late }\end{array}$ & FY 2001 \\
\hline Enforceable Agreemen & 0 & 0 & 0 & 0 & 0 & 0 & 0 & 0 \\
\hline DOE-HQ & 0 & 0 & 0 & 0 & 0 & 0 & 0 & 0 \\
\hline RL & 0 & 0 & 0 & 0 & 0 & 1 & 0 & 1 \\
\hline Total Project & 0 & 0 & 0 & 0 & 0 & 1 & 0 & 1 \\
\hline
\end{tabular}

\section{Tri-Party Agreement / EA Milestones}

Nothing to report at this time.

\section{DNFSB Commitments}

Nothing to report at this time.

\section{MILESTONE EXCEPTION REPORT}

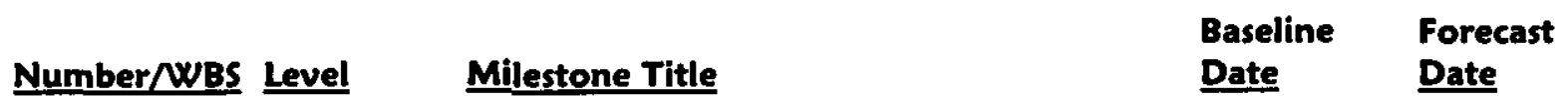

\section{OVERDue - 0}

\section{FORECAST LATE - 0}




\section{Performance Objectives}

Budgeted Capacity vs. Actual Production - TW01

\section{Green}

Novem ber 17,2000

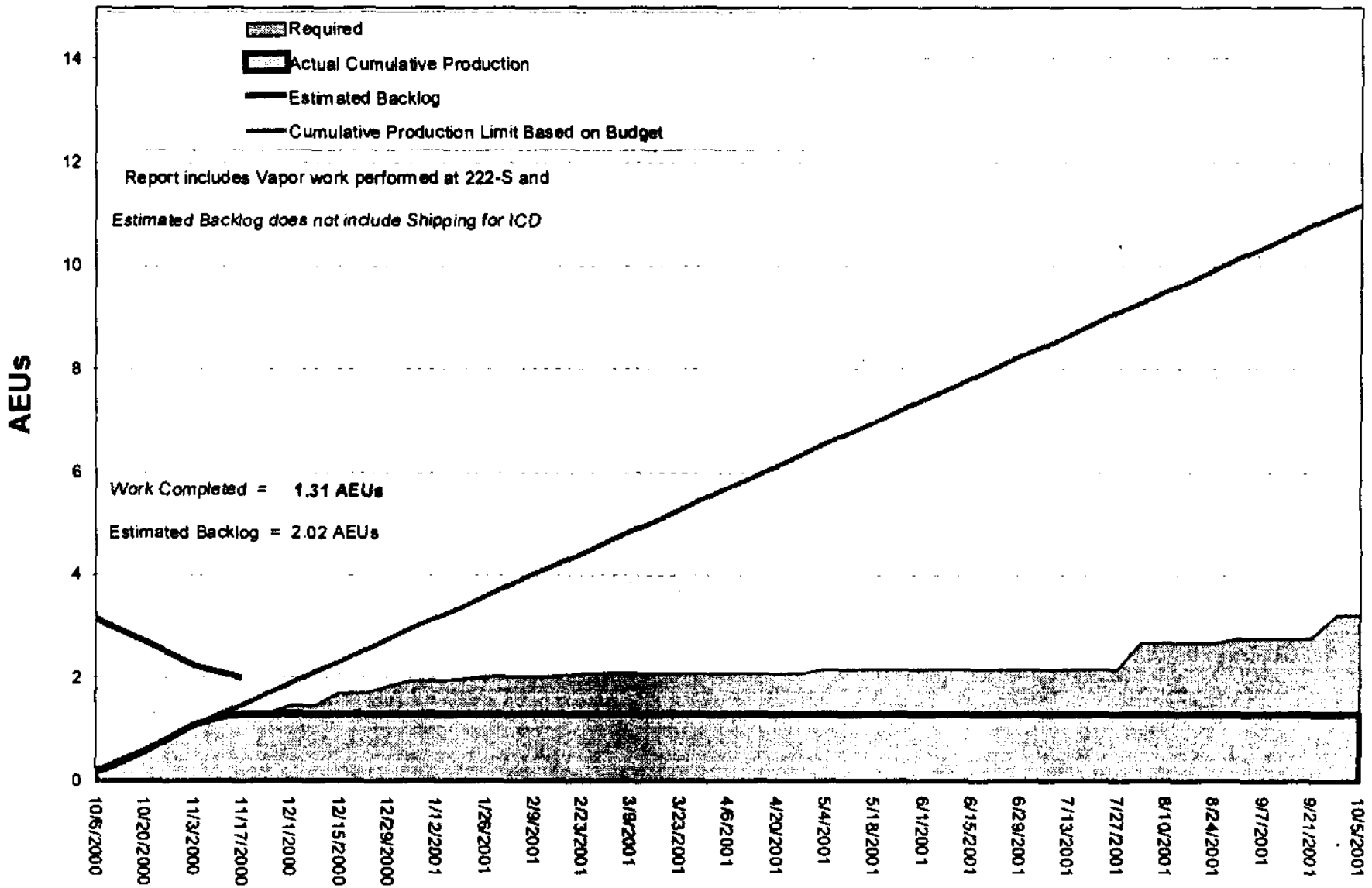

Processed a total of 0.8 AEUs at the 222-S Laboratory in October (versus 0.2 AEUs planned) in support of the RPP (TWRS) tank characterization program. Production through November 17 is 1.3 AEUs.

\section{KEY INTEGRATION ACTIVITIES}

- Continue to support ORP efforts to establish required analytical support for Waste Treatment Plant (WTP) design and operation.

- Continue to support Waste Management headspace gas analyses for transuranic (TRU) waste shipment to WIPP. 


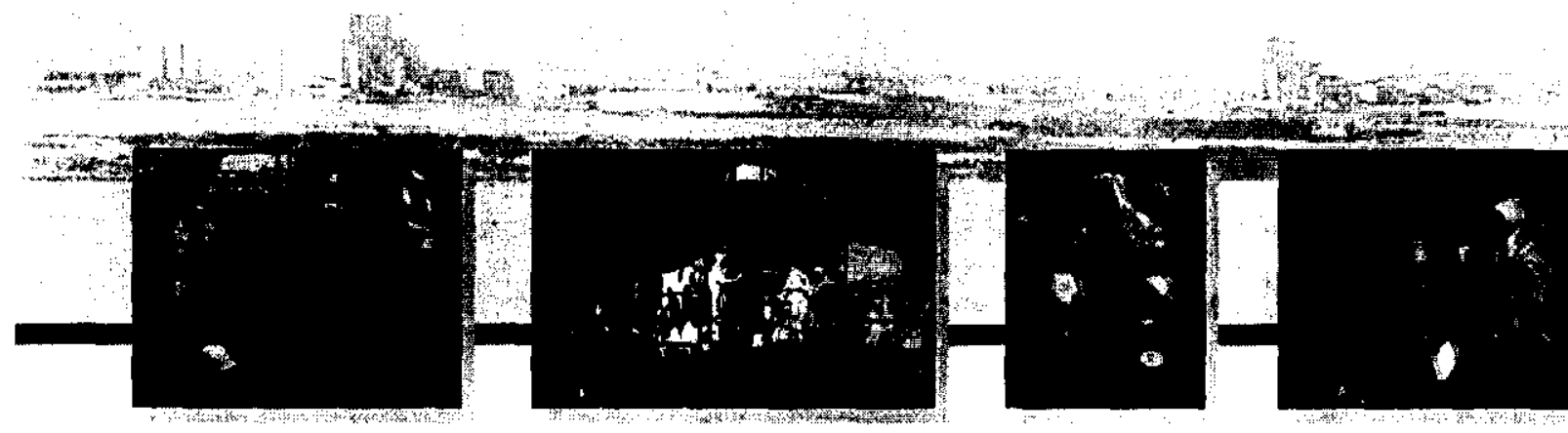

\section{Section C:1 Nuclear Material Stabilization}

PROJECT MANAGERS

P.M. Knollmeyer, RL (509) 376-7435

G.W. Jackson, FH (509) 373-6622 


\section{SUMMARY}

The Nuclear Material Stabilization (NMS) mission consists of the Plutonium Finishing Plant (PFP), WBS 1.4.5 (PBS TP05).

NOTE: Unless otherwise noted, the Safety, Conduct of Operations, Milestone Achievement, and Cost/Schedule data contained herein is as of October 31,2000. All other information is as of November 20, 2000 unless otherwise stated.

Through November 20, 2000, there have been 355 calendar days or more than $1.1 \mathrm{M}$ person hours without a lost workday injury.

Fiscal-year-to-date milestone performance (EA, DOE-HQ, and RL) shows that one of nine milestones ( 9 percent) was completed on or ahead of schedule, none were completed late, and none are overdue. Although seven additional milestones are scheduled for completion later this fiscal year, no milestones were scheduled for completion during this report period. Further details can be found in the milestone exception report following the cost and schedule variance analysis.

\section{ACCOMPLISHMENTS}

\section{Maintain Safe and Compliant PFP}

- The PFP is initiating a Hanford Site Pilot Program to provide the best possible outcome for victims who suffer Sudden Cardiac Arrest (SCA) at the facility. Six (6) automatic external defibrillators are being procured and are expected to be installed by the end of November.

\section{Maintain Safe \& Secure SNM}

- Successfully completed the International Atomic Energy Agency (IAEA) annual Physical Inventory Verification. No findings or observations resulted from this inventory.

\section{Oxides/Metals/Polycubes Stabilization}

- Processing of plutonium metals was initiated on September 29, 2000 six weeks ahead of the November 10, 2000 scheduled start date. Early startup of this milestone effort supports a Spring, 2001 Defense Nuclear Facilities Safety Board (DNFSB) commitment to complete packaging of the metal inventory. At this time nearly $12 \%$ of the inventory has been stabilized and packaged in bagless transfer containers from the newly installed and operational Bagless Transfer System (BTS).

- An ALARA analysis of polycube stabilization was initiated to include a cost/benefit analysis of projected dose reduction recommendations. The ALARA analysis draft is due the end of November, and the cost/benefit analysis is due the end of December. 


\section{Solution Stabilization}

- Unrestricted Operations of the Magnesium Hydroxide Precipitation Process (MHPP) was approved by the Plant Director on October 16, 2000.

\section{Residue Stabilization}

- Requalified the Segmented Gamma Scan Assay System (SGSAS) to Nondestructive Assay (NDA) items containing up to 142 grams, an increase from the previous limit of 88 grams $\mathrm{Pu}$. This improvement reduces the need to split items and also allows blending of items; thus reducing total number of items to seal out and perform NDA.

\section{Project W-460}

- Completed Bagless Transfer System (BTS) startup plan actions and received PFP Director approval for unrestricted BTS operations.

- Westinghouse Savannah River Company (WSRC) indicates fabrication of the 2736-ZB BTS and Outer Can Welder (OCW) remains on schedule for shipment on January 8, 2001 and February 14, 2001, respectively. This second system will double the thermal stabilization capability and eliminate " building to building" material transfers.

\section{SAFETY}

Excellent safety performance is continuing. One million safe hours were achieved in October.

Lost Away Workday Case Rate has had a significant decrease, with thirteen of fourteen months at zero. The current rate is exceptionally low. Occupational Safety and Health Act (OSHA) recordable case rate is stable and there have been more than 631,000 hours since the last OSHA recordable case. This is a significant improvement in comparison to the adverse trend of spring, 1999.

FY 2000 OSHA case rate and DOE Safety Cost Index were very favorable. DOE Safety Cost Index has been below average for eight months in a row. The Index has a new average and new control limits reflecting the significant decrease noted earlier in the year. 


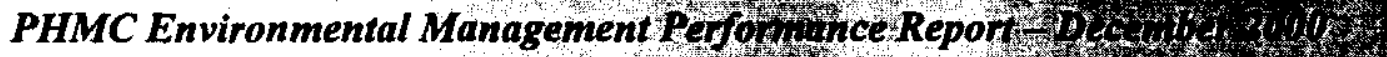
Section C: 1 - Nuclear Materials Stabilizatow

12 - Lost Away Workday Case Rate

10

\section{Cases per 200,000 hours}
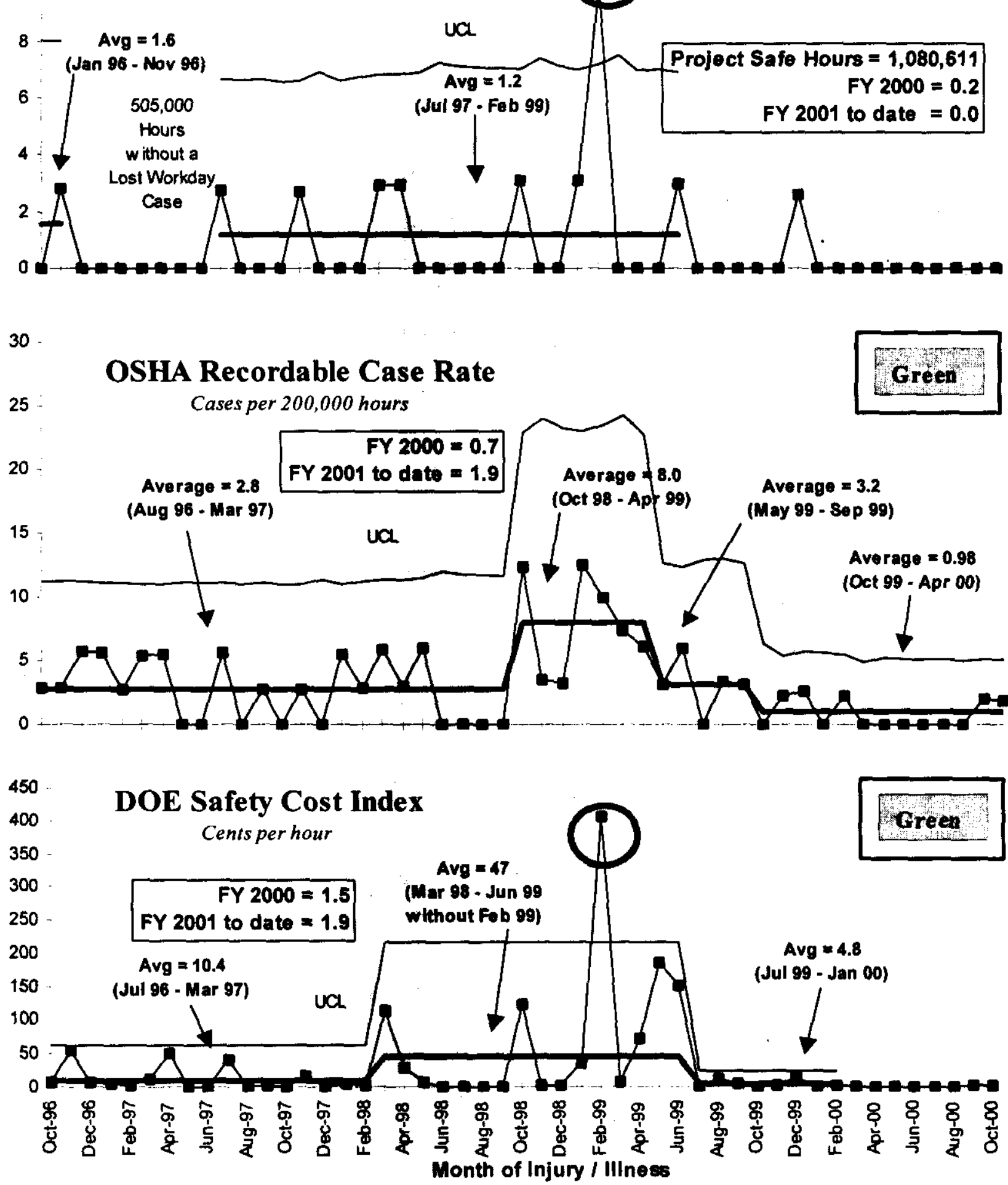


\section{CONDUCT OF OPERATIONS / ISMS STATUS}

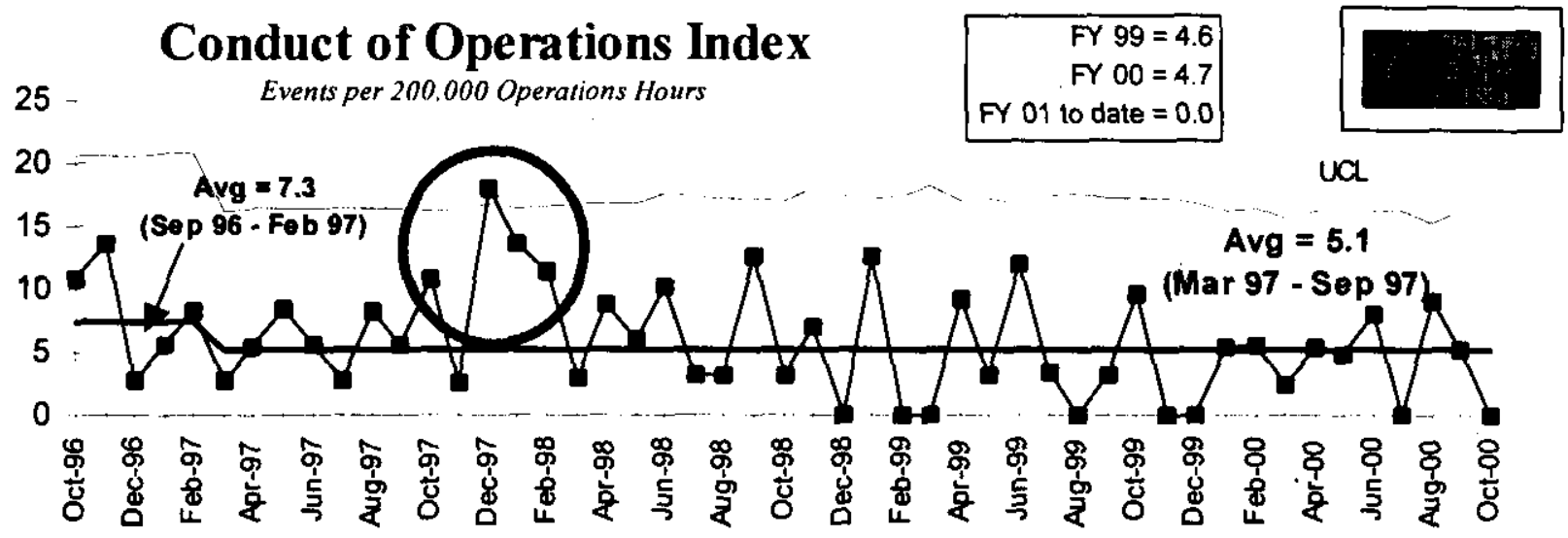

Number of Reports Past 12 Months

$\begin{array}{lllllllllll}0 & 2 & 4 & 6 & 8 & 10 & 12 & 14 & 16 & 18 & 20\end{array}$

Personnel Contamination

Procedure Problem

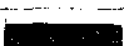

$4.9-10,-12,-10$

Management Problem

Work Control

\section{ISMS STATUS}

Continued safety improvements at PFP through ISMS:

- ISMS implementation results continue

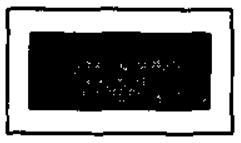

- Automated Job Hazards Assessment tool refinement and increased worker involvement

- Improvement in pre-job safety briefings and field walk-downs of job sites

- PFP preparing for participation in ISMS National Conference, December 5, 2000.

\section{BREAKTHROUGHS / OPPORTUNITIES FOR IMPROVEMENT}

\section{Breakthroughs}

- Nothing to report at this time. 


\section{Opportunities for Improvement}

- Exposure Reduction - Funding has been approved and procurement is underway to purchase a remote controlled video camera that will reduce employee exposure in the $2736-\mathrm{ZB}$ vaults by performing remote video inspections and inventories.

- Process Efficiency - Work is underway to identify alloys that can be stabilized early using potentially available muffle furnace capacity. Having backup material options will ensure maximum use of available furnace capacity.

- Process Improvement - A containment tent has been fabricated and installed to support residue sealout operations from glovebox $\mathrm{HC}-46 \mathrm{~F}$ in room 170 of $234-5 \mathrm{Z}$. This allows immediate sealout and provides the opportunity for concurrent operations with an expected significant increase in throughput.

- Loss On Ignition (LOI) Equipment Upgrade - Calibration and testing of the Supercritical Fluids Extraction (SFE) equipment for moisture measurement in stabilized oxides was completed. Operation of this new equipment indicated that eight previously stabilized items that had exceeded LOI limits were actually well within acceptable limits for storage.

\section{UPCOMING ACTIVITIES}

- Delivery of the 2736-ZB BTS and OCW is expected during the second quarter of FY 2001.

- Complete repackaging of Pu metal inventory by March 31, 2001. (Milestone TRP-02-500).

- Complete modifications to one vault cubicle by April 2, 2001. (Milestone TRP-99-412).

- Complete repackaging and shipping of Rocky Flats Ash to the Central Waste Complex (CWC) by April 30, 2001. (Milestone TRP-01-515).

- Stabilization and packaging of polycubes consistent with DOE Standard DOE-STD-3013-99 is scheduled to begin in the third quarter of FY 2001.

- Complete alloy stabilization by June 30, 2001 (Milestone TRP-01-501). 
PHMC Environmental Management Performance Report - Decenbe 2000

Section C: 1 - Nuclear Materials Stabilization

Cost Performance (\$M):

\begin{tabular}{|l|c|c|c|}
\hline & BCWP & ACWP & VARIANCE \\
\hline Nuclear Materials Stabilization & $\$ 5.4$ & $\$ 3.9$ & $\$ 1.4 \mathrm{M}^{*}$ \\
\hline
\end{tabular}

* Rounding

The favorable cost variance is primarily due to contract accrual reversals, anticipated labor underruns, and a continuance of spending controls initiated in FY 2000.

\section{Schedule Performance (\$M):}

\begin{tabular}{|l|c|c|c|}
\hline & BCWP & BCWS & VARIANCE \\
\hline Nuclear Materials Stabilization & $\$ 5.4$ & $\$ 6.6$ & $-\$ 1.3 \mathrm{M}^{*}$ \\
\hline
\end{tabular}

* Rounding

The current unfavorable schedule variance is due to the behind schedule status of ash and solutions processing. However, a number of process improvements are completed, or underway, that are expected to increase throughput of residues packaging and solutions stabilization processing. Continued delays in obtaining Critical Decision (CD) \# 3 approval for Project W-460 is also a contributing factor.

\section{FY 2001 Cost/Schedule Performance - All Fund Types Cumulative to Date Status - $(\$ 000)$}

\begin{tabular}{|c|c|c|c|c|c|c|c|c|c|c|c|c|c|}
\hline & & & & & & & & & & & & & ellow \\
\hline & & & & & & & & TD & & & & & \\
\hline & y PBS & & cWs & & CWP & & CWP & & sv & $\%$ & cV & $\%$ & PEM" \\
\hline $\begin{array}{l}\text { WBS } 1.4 .5 \\
\text { PBS TP05 }\end{array}$ & $\begin{array}{l}\text { PFP } \\
\text { Deactivation }\end{array}$ & $\$$ & 6,629 & $\$$ & 5,355 & $\$$ & 3,945 & $\$$ & $(1,273)$ & $-19 \% \$$ & 1,410 & & $\$ 106,494$ \\
\hline & Total & $\$$ & 6,629 & $\$$ & 5,355 & $\$$ & 3,945 & $\$$ & $(1,273)$ & $-19 \% \$$ & 1,410 & $26 \%$ & $\$ 106,494$ \\
\hline
\end{tabular}

*Authorized baseline per the Integrated Planning Accountability, and Budget System (IPABS) Project Execution Module (PEM). RL-Directed Costs (steam) are included in the PEM BCWS. 


\section{Cost/SChedule Performance Indices (MONTHLY AND FYTD)}

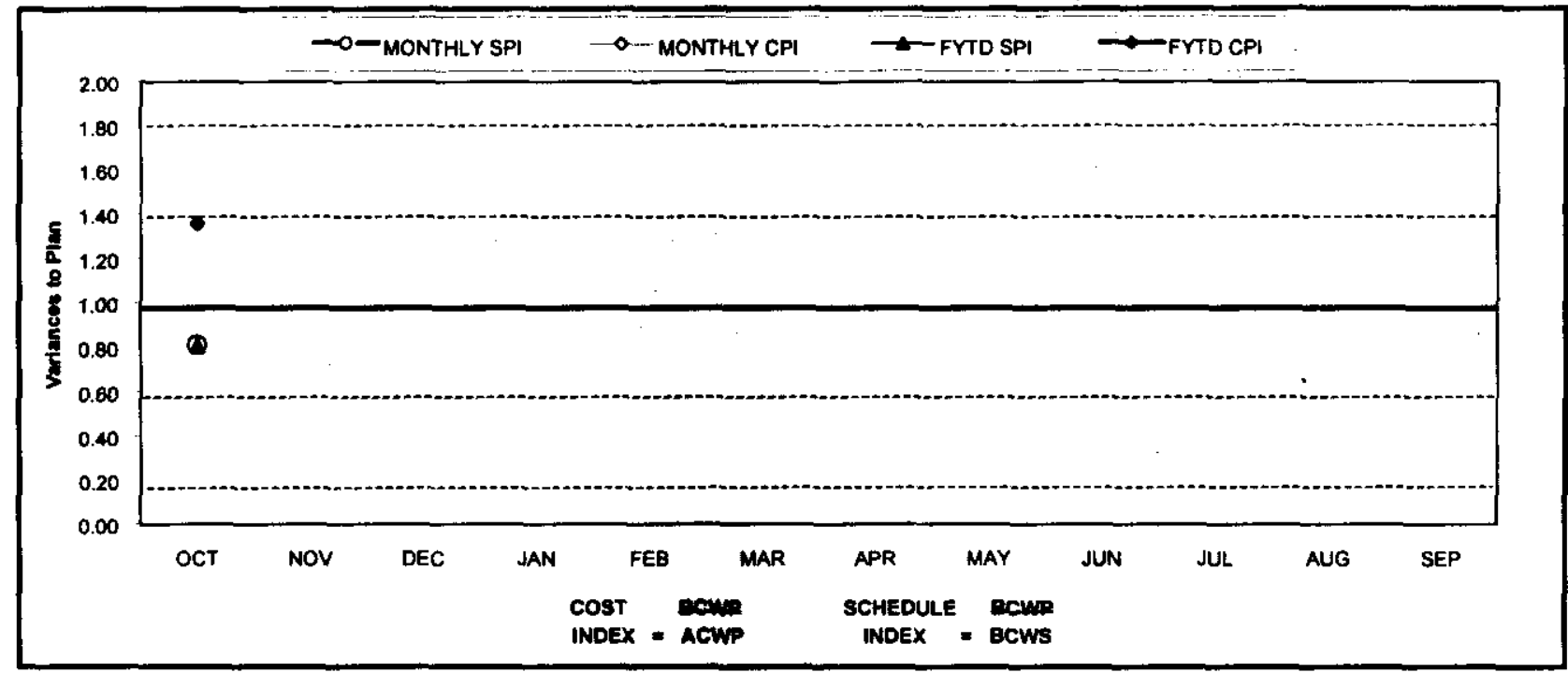

\begin{tabular}{|c|c|c|c|c|c|c|c|c|c|c|c|c|}
\hline Ex, 20101 & OCT & NOY & $D \times C$ & IAN & FPR & MAR & APR & MAY & IUN & IIIl. & Allf. & SEP \\
\hline \multirow{2}{*}{\multicolumn{2}{|c|}{ MONILALYSIL }} & & & & & & & & & & & \\
\hline & 1.36 & & & & & & & & & & & \\
\hline \multicolumn{13}{|l|}{ FYTD_SEL } \\
\hline \multicolumn{13}{|l|}{ FYOT CPI } \\
\hline MONTHILY RCWS & 56,629 & 510,568 & 59.058 & 59.257 & 52.392 & 58.483 & 58.448 & s.e.292 & 57.376 & 52182 & 52,234 & $\$ 11.876$ \\
\hline MONTHLY BCWP & 53,355 & & & & & & & & & & & \\
\hline MONTHILYACWP & 53.945 & & & & & & & & & & & \\
\hline FYTD BCYS & 5.629 & 517197 & 526,254 & $\$ 35.512$ & 89.104 & $551, \$ 87$ & 560035 & 570,327 & 577702 & 584.884 & 594.618 & $\$ 1.06 .494$ \\
\hline FYODRCWP & 55.355 & & & & & & & & & & & \\
\hline FYTDACWP & 53.945 & & & & & & & & & & & \\
\hline
\end{tabular}

\section{COST VARIANCE ANALYSIS: (\$1.4M)}

\section{$\underline{\text { WBS/PBS }} \quad \underline{\text { Title }}$}

\subsection{0/TP05 Maintain Safe \& Secure SNM (\$165K)}

Description and Cause: The favorable cost variance is attributable to a shortage of staff, contract accrual reversals, and judicious use of overtime in completing the annual IAEA physical inventory verification and the reconciliation of the Material Balance Area (MBA) 213 inventory. Impact: None forecast.

Corrective Action: No corrective action necessary. 
PHMC Environmental Management Performance Report-Decemb 2000

Section C: 1-Nuclear Materials Stabilization

\subsection{1/TP05 Maintain Safe \& Compliant PFP (\$705K)}

Description and Cause: The favorable cost variance is due primarily to contract accrual reversals from FY 2000 and late invoicing of October 2000 contracts that have not been costed. Impact: None forecast.

Corrective Action: Contract and material purchases will be monitored as appropriate and, if necessary, apply accruals to account for delayed billing.

\subsection{2/TP05 PFP Fee Allocation (-\$571K)}

Description and Cause: A double fee accrual occurred during October.

Impact: None forecast.

Corrective Action: A cost correction is being processed that will remove the double entry.

\subsection{3/TP05 Stabilization of Nuclear Material (\$624K)}

Description and Cause: The favorable cost variance is attributable to contract accrual reversals and lower than anticipated project management costs.

Impact: None forecast.

Corrective Action: No corrective action necessary.

\subsection{4/TP-05 Disposition of Nuclear Material (\$312K)}

Description and Cause: The favorable cost variance is due to accrual reversals for FY 2000 workscope that have not been re-accrued or paid.

Impact: None forecast.

Corrective Action: Will self correct. No corrective action necessary.

\section{SCHEDUle VARIANCE ANALYsIS: (-\$1.3M)}

\section{WBS/PBS}

\subsection{3/TP05 Stabilization of Nuclear Material (-\$533K)}

Description and Cause: The unfavorable schedule variance is due to the recalibration of the Segmented Gamma Assay System (now completed) that impacted ash processing, hardware, procedural, and programmatic evaluations in support a of solutions and residue processing, as well as solutions and residue labor underruns.

Impact: A potential delay is anticipated in completion of the solutions stabilization program. Corrective Action: Solutions and Residue process improvement evaluations noted above are underway that will potentially improve solutions and residue throughput.

\subsection{4/TP05 Disposition of Nuclear Material (-\$669K)}

Description and Cause: The unfavorable schedule variance is primarily due to Project W-460 equipment and material procurements in support of the 2736-ZB BTS construction that have not yet been delivered and costed. Shipments of packaged Rocky Flats Ash to the Central Waste Complex are also behind schedule.

Impact: None forecast.

Corrective Action: No corrective action necessary. 


\section{ISSUES}

\section{Technical Issues}

The quantity of boats from the precipitation process is higher than expected or forecasted in the baseline estimates and schedules. Review of the data from the characterization-processing task indicates the need to improve current throughput estimates for processing the remaining solutions inventory. A processing strategy for improving the current throughput estimates is currently being developed.

Filtrate from the precipitation process is requiring recycling to meet the discharge limit for the drum loading station. Techniques for improving the processing are being worked jointly with members of the PPSL and PNNL staffs.

The rate of throughput for polycube processing has been determined to be less than planned during the latest IPMP update. Currently working on revision of processing method to reduce the offgas rate and allowing an increase in throughput.

Portions of the oxides to be processed contain fairly high levels of chloride. Technology is available to 'wash' the oxides prior to processing. Purchasing the necessary equipment will be revisited at a later date.

\section{DOE/Regulator/External Issues}

Nothing to report at this time.

\section{Baseline Change Requests Currently in Process $(\$ 000)$}

\begin{tabular}{|c|c|c|c|c|c|c|c|c|c|}
\hline $\begin{array}{l}\text { PROJECT } \\
\text { CHANGE } \\
\text { NUMBER }\end{array}$ & $\begin{array}{l}\text { DATE } \\
\text { ORIGIN. }\end{array}$ & $\begin{array}{l}\text { BASELINE CHANGE REQUEST } \\
\text { TITLE }\end{array}$ & $\begin{array}{c}\operatorname{cost} \\
\text { IM PACT } \\
\text { S000 }\end{array}$ & $\begin{array}{l}\mathbf{s} \\
\mathbf{C} \\
\mathrm{H}\end{array}$ & $\begin{array}{l}\mathrm{T} \\
\mathrm{E} \\
\mathrm{C} \\
\mathrm{H}\end{array}$ & $\begin{array}{l}\text { DATETO } \\
\text { CCB }\end{array}$ & CCBAPR'VD & $R L A R ' V D$ & $\begin{array}{l}\text { CURRENT } \\
\text { STATUS }\end{array}$ \\
\hline FH-2001.001 & T2.Sep-00 & Basc Operations keduction & $\langle, 56,790\rangle$ & $\mathbf{x}$ & $\mathrm{x}$ & $23-0 \mathrm{cl}-00$ & $23.0 \mathrm{ct}-00$ & & $\lambda T R L$ \\
\hline FH.2001.002 & $12.5<p-00$ & FYoI Fee Reduction to $90 \%$ & $\langle \$ 600\rangle$ & $\mathbf{x}$ & $x$ & $25.0 \mathrm{ct}-00$ & $25.0 \mathrm{ct}-00$ & & At RL \\
\hline FH.2000.003 & $12-S \in p-00$ & Addition of High Priority Workecope & 59,707 & $x$ & $x$ & $25-0 c t-00$ & $23-0<t-00$ & & $A \geq R L$ \\
\hline FSP.2001-003 & $12-\operatorname{sep}-00$ & Video C̣ontrol camera & $\$ 66$ & $\mathrm{x}$ & $\mathbf{x}$ & Approved by & George Jackson & on $1 / 1 / 1 / 2000$ & Complete \\
\hline FSP-2000.079 & $12 \cdot 5$ ep -00 & $\begin{array}{l}\text { FY } 2001 \mathrm{MYWP} \text { \& Baseline } \\
\text { Revisions }\end{array}$ & so & $x$ & $x$ & $29-A \cup B-00$ & $31-A$ ug.00 $\mid$ & & $A \subset R L$ \\
\hline FSP.2001-009 & $12 \cdot 5 \mathrm{cp}=00$ & Remote Material Surveillance & 5548 & $\mathbf{x}$ & $\mathbf{x}$ & & & & \\
\hline FSP-2001-013 & $28-\mathrm{Nov}-00$ & $\begin{array}{l}\text { Tank } 241 \cdot Z-361 \text { Continued } \\
\text { Operations }\end{array}$ & 5150 & $x$ & $x$ & $30-\mathrm{N}$ ov -00 & 6-Dec.00 & & In Process \\
\hline FSP.2001.014 & $29 \cdot$ Nov -00 & Extend Solutions Campaign & $(\$ 407)$ & $\mathbf{x}$ & $\mathbf{x}$ & $11-D e c .00$ & & & \\
\hline \multicolumn{10}{|c|}{ ADVANCED WORK AUTHORIZATION } \\
\hline AWA-01-00I & & Tank 241.Z-361 Incremental Work & 350 & $\mathrm{x}$ & $x$ & $70.0 \mathrm{ct}-00$ & $10.0 \mathrm{ct}-00$ & T.8.0c1-00 & Complete \\
\hline$A W A-0 !-002$ & & PFP Parking Lol Uperade & 5130 & $x$ & $x$ & & & & \\
\hline AWA.01-003 & & Mg(Oh)2 Filtrate Disposal & 575 & $x$ & $\mathbf{x}$ & I3-Nov-00 & $13-\mathrm{N}$ ove00 & $\mathbf{N} / \mathbf{A}$ & Complete \\
\hline$A W A-01 \cdot 00(14$ & & Mg(Oh)2 FSAR Addendum & 570 & $\mathbf{x}$ & $x$ & $13-\mathrm{N}$ ov-00 & 13-Nov-00 & $N / A$ & Complete \\
\hline
\end{tabular}


PHMC Environmental Management Performance Report $x$

Section C: 1 - Nuclear Materials Stabilization

Milestone ACHIEVEMENT

\begin{tabular}{|c|c|c|c|c|c|c|c|c|}
\hline \multirow[b]{2}{*}{ MLSTENE TYPE } & \multicolumn{4}{|c|}{ FISCAL YEAR-TO-DATE } & \multicolumn{3}{|c|}{ REMAINING SCHEDULED } & \multirow[b]{2}{*}{$\begin{array}{l}\text { TOTAL } \\
\text { FY } 2001\end{array}$} \\
\hline & $\begin{array}{c}\text { Completed } \\
\text { Early }\end{array}$ & $\begin{array}{c}\text { Completed } \\
\text { On } \\
\text { Schedule } \\
\end{array}$ & $\begin{array}{c}\text { Completed } \\
\text { Late }\end{array}$ & Overdue & $\begin{array}{c}\text { Forecast } \\
\text { Early }\end{array}$ & $\begin{array}{c}\text { Forecast } \\
\text { On } \\
\text { Schedule }\end{array}$ & $\begin{array}{c}\text { Forecast } \\
\text { Late }\end{array}$ & \\
\hline Enforceable Agreement & 0 & 0 & o & 0 & 0 & 3 & 1 & 4 \\
\hline DOE-HO & 0 & 0 & of & 0 & 0 & 0 & 0 & 0 \\
\hline RL & 1 & 0 & 0 & 0 & 0 & 4 & 0 & 5 \\
\hline Tatal Project & 1 & 0 & 0 & 0 & 0 & 7 & 1 & 9 \\
\hline
\end{tabular}

Only TPA/EA milestones and all FY2001 overdue and forecast late milestones are addressed in this report. Milestones overdue are deleted from the Milestone Exception Report once they are completed. The following chart summarizes the FY2001 TPA/EA milestone achievement and a Milestone Exception Report follows. The last milestone table summarizes the first six months of FY 2002 TPA/EA milestones.

FY 2001 Tri-Party Agreement / EA Milestones

\begin{tabular}{|l|l|l|}
\hline \multicolumn{1}{|c|}{ Number } & \multicolumn{1}{|c|}{ Milestone Title } & \multicolumn{1}{c|}{ Status } \\
\hline $\begin{array}{l}\text { M-083-07 } \\
\text { (TRP-01-515) }\end{array}$ & $\begin{array}{l}\text { "Complete Repackaging \& } \\
\text { Shipping of Rocky Flats Ash to } \\
\text { the CWC" }\end{array}$ & Due April 30, 2001 - On schedule. \\
\hline $\begin{array}{l}\text { M-083-07 } \\
\text { (TRP-01-516 }\end{array}$ & $\begin{array}{l}\text { "Complete Requirements to } \\
\text { Ship Rocky Flats Ash to WIPP" }\end{array}$ & Due June 1, 2001 - On schedule \\
\hline
\end{tabular}

DNFSB Commitments

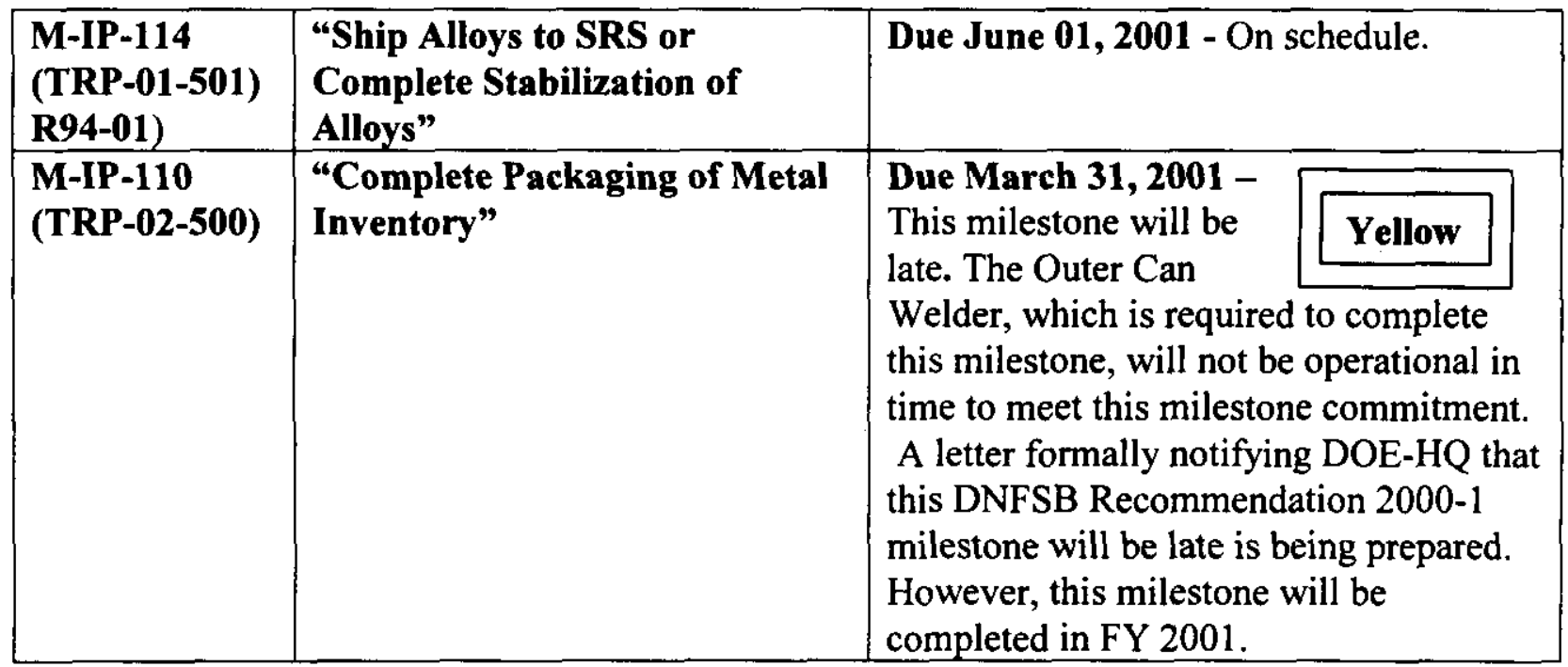


PHMC Environmental Management Performance Report-December 2000

Section C: 1 - Nuclear Materials Stabilization

\section{MILESTONE EXCEPTION REPORT}

Number/WBS Level

Milestone Title

Baseline

Date

Forecast

Date

Overdue - 0

FY 2002 Tri-Party Agreement / EA Milestones

\begin{tabular}{|c|l|c|}
\hline Number & \multicolumn{1}{|c|}{ Milestone Title } & Status \\
\hline & Nothing to report at this time. & \\
\hline
\end{tabular}

DNFSB Commitments

\begin{tabular}{|l|l|l|}
\hline $\begin{array}{l}\text { R94-01 } \\
\text { (TRP-01-500) }\end{array}$ & $\begin{array}{l}\text { “Complete Stabilization \& } \\
\text { Packaging Plutonium } \\
\text { Solutions” }\end{array}$ & Due December 31, 2001 - On schedule. \\
\hline
\end{tabular}

\section{Performance Objectives \\ Oxides/Metals/Polycubes Stabilization}

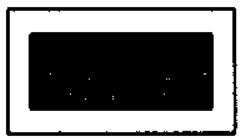

PFP METALS PROCESSING

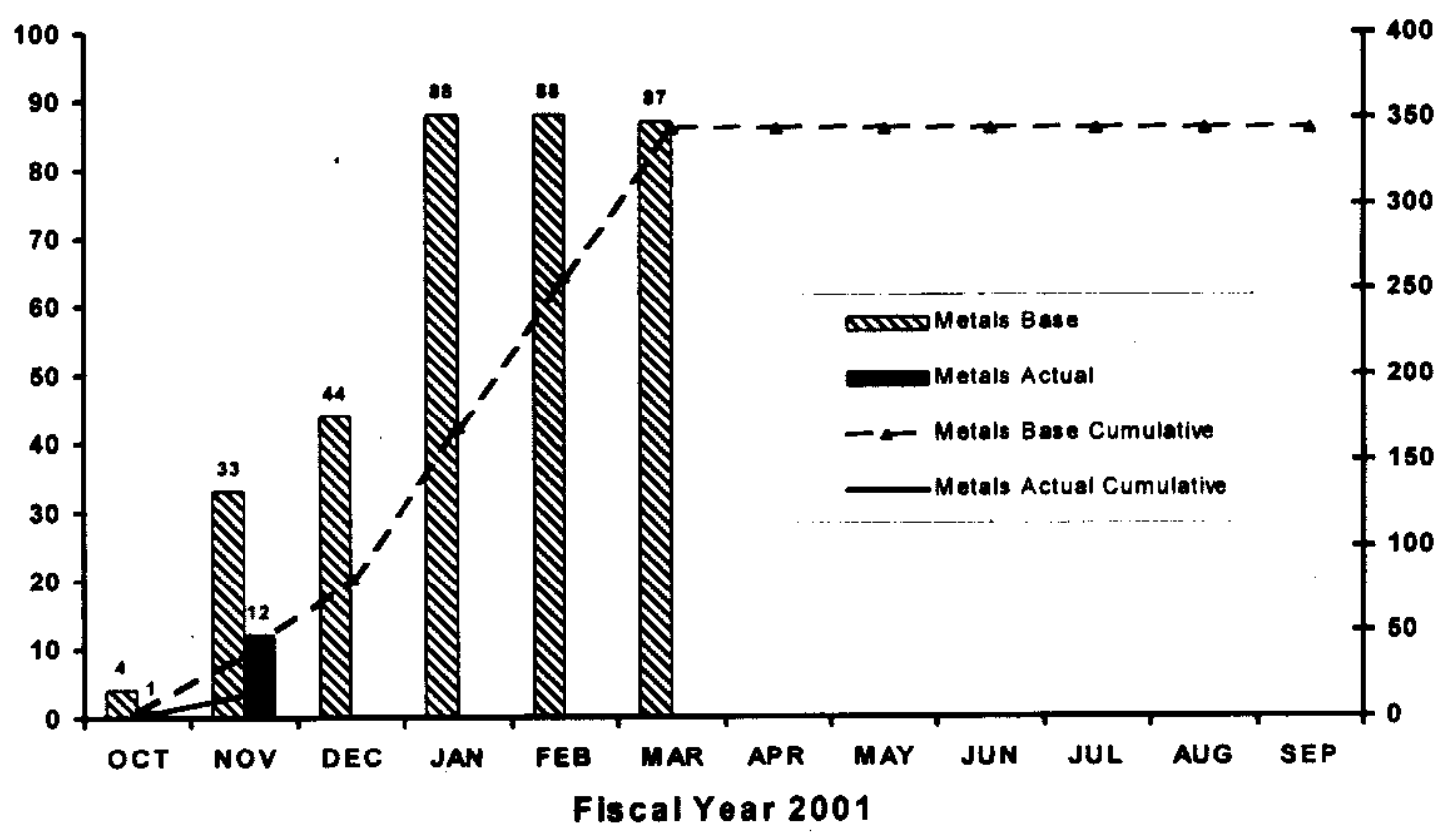


PHMC Environmental Management Performance Report-December 2000

Section C: 1 - Nuclear Materials Stabilization

Solution Stabilization

Yellow

PFP SOLUTIONS PROCESSING

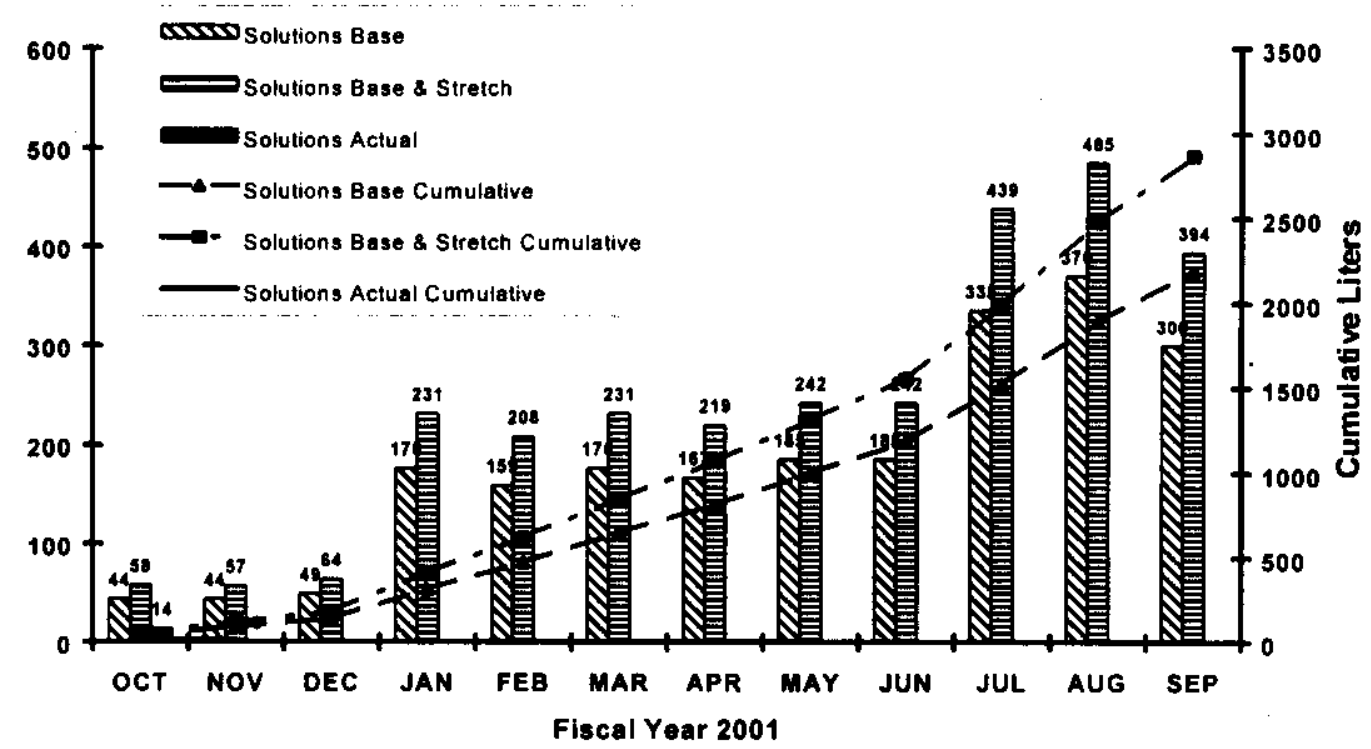

The quantity of the boats from the precipitation process is significantly higher than forecasted in the baseline estimates and schedules.

Residues Stabilization

Yellow

PFP ASH PROCESSING

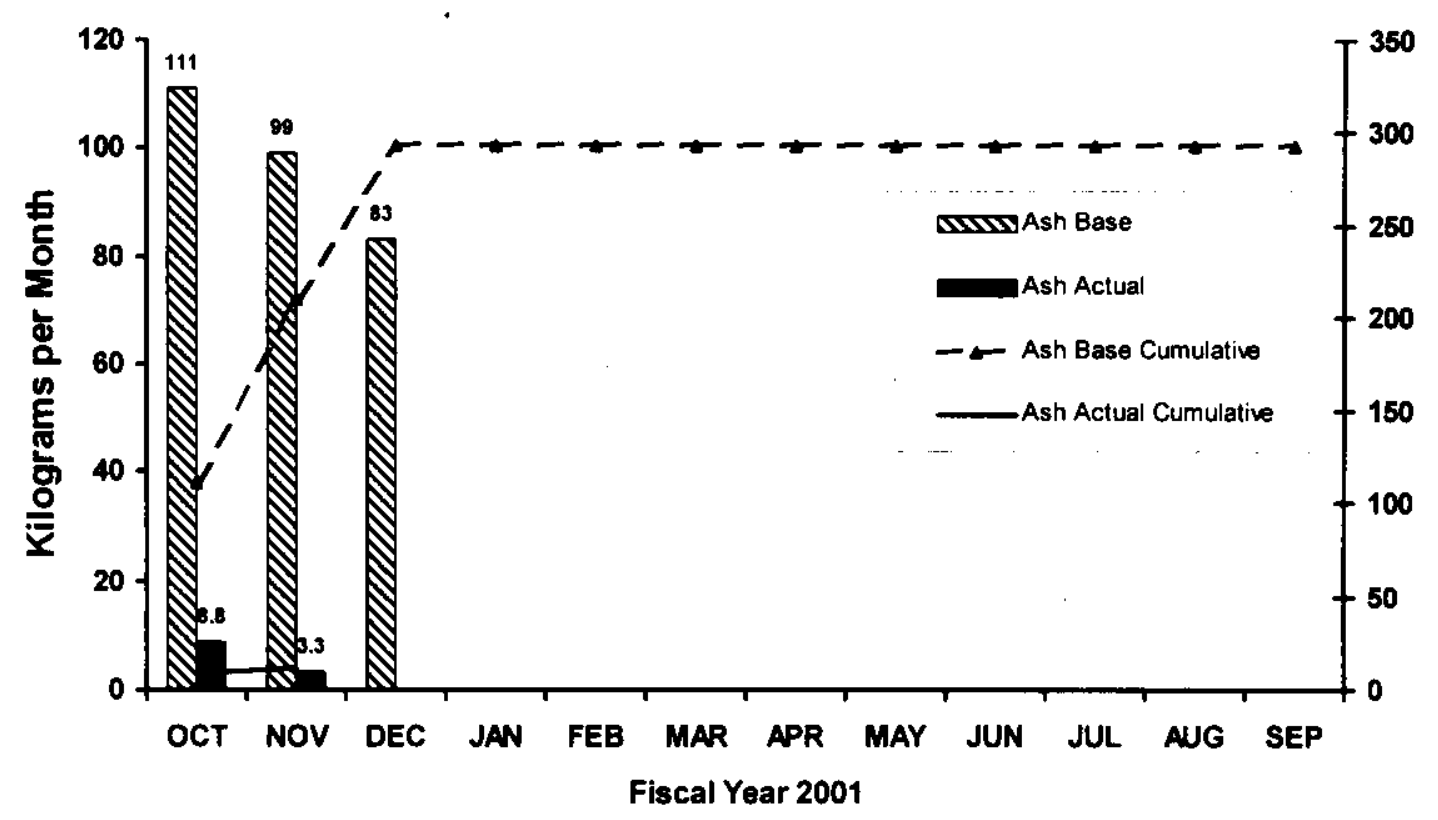

Significantly behind schedule for anticipated target date, however the April Tri-Party Agreement Milestone (M-083-07) will be met. 
PHMC Environmental Management Performance Report - Decenber 2000 Section C: 1 - Nuclear Materials Stabilization

\section{Packaging of Stabilized Material}

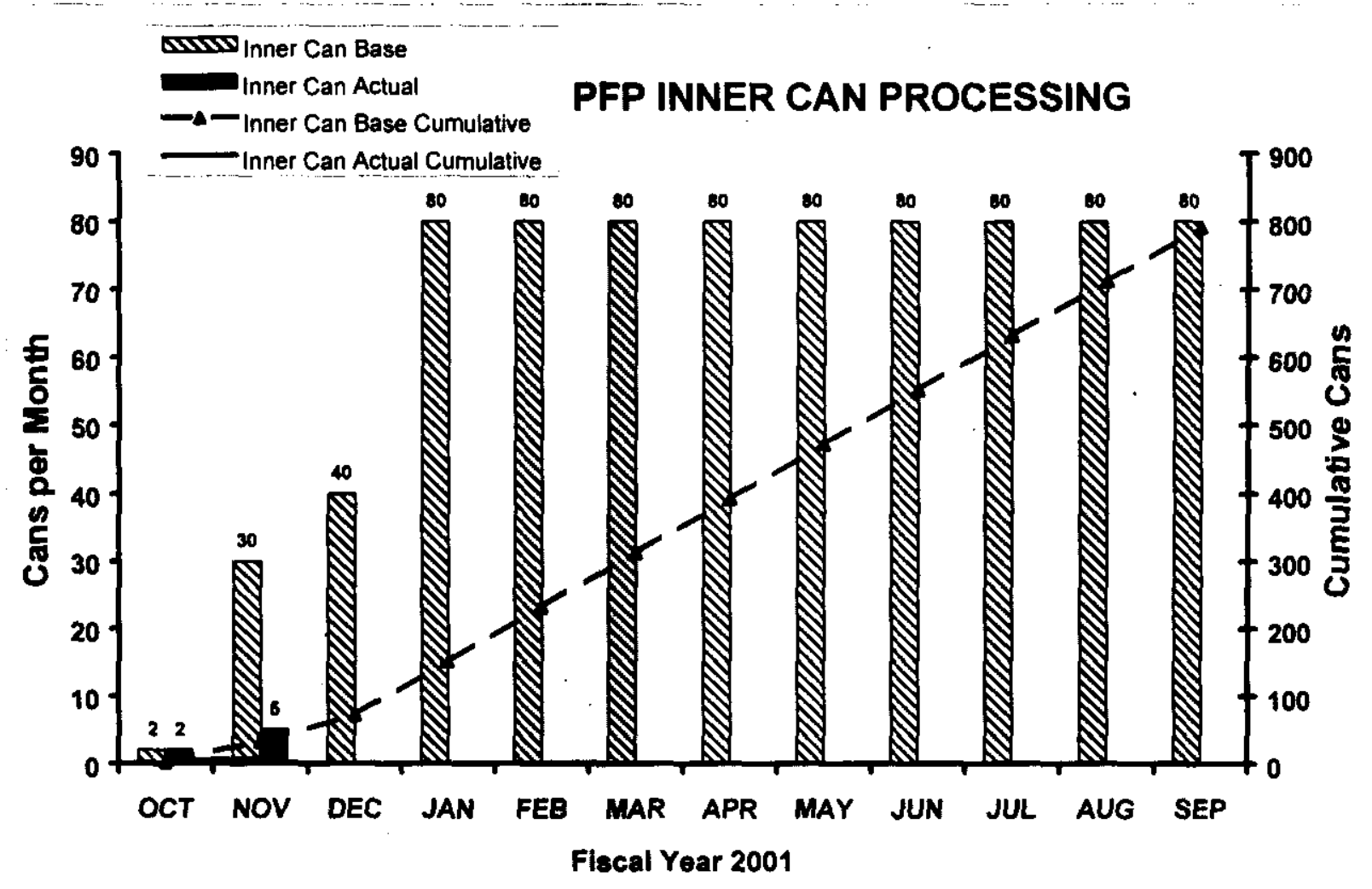

\section{KEY INTEGRATION ACTIVITIES}

- Support to the Central Waste Complex continued in completing activities necessary to allow acceptance of packaged residues. This support included security upgrades and issuance of Criticality Safety Evaluation (CSER) and SARP documentation.

- A recent FH visit to Westinghouse Savannah River Company (WSRC) indicates the 2736-ZB Bagless Transfer System and the Outer Can Welder remain on schedule for shipment on January 8, 2001 and February 14, 2001, respectively. This second system will double the thermal stabilization capability and eliminate "building to Building" material transfers.

- RL approval for Project W-460 Critical Decision \#3 is necessary to preclude further impact to procurements in support of 2736-ZB stabilization and packaging equipment. 


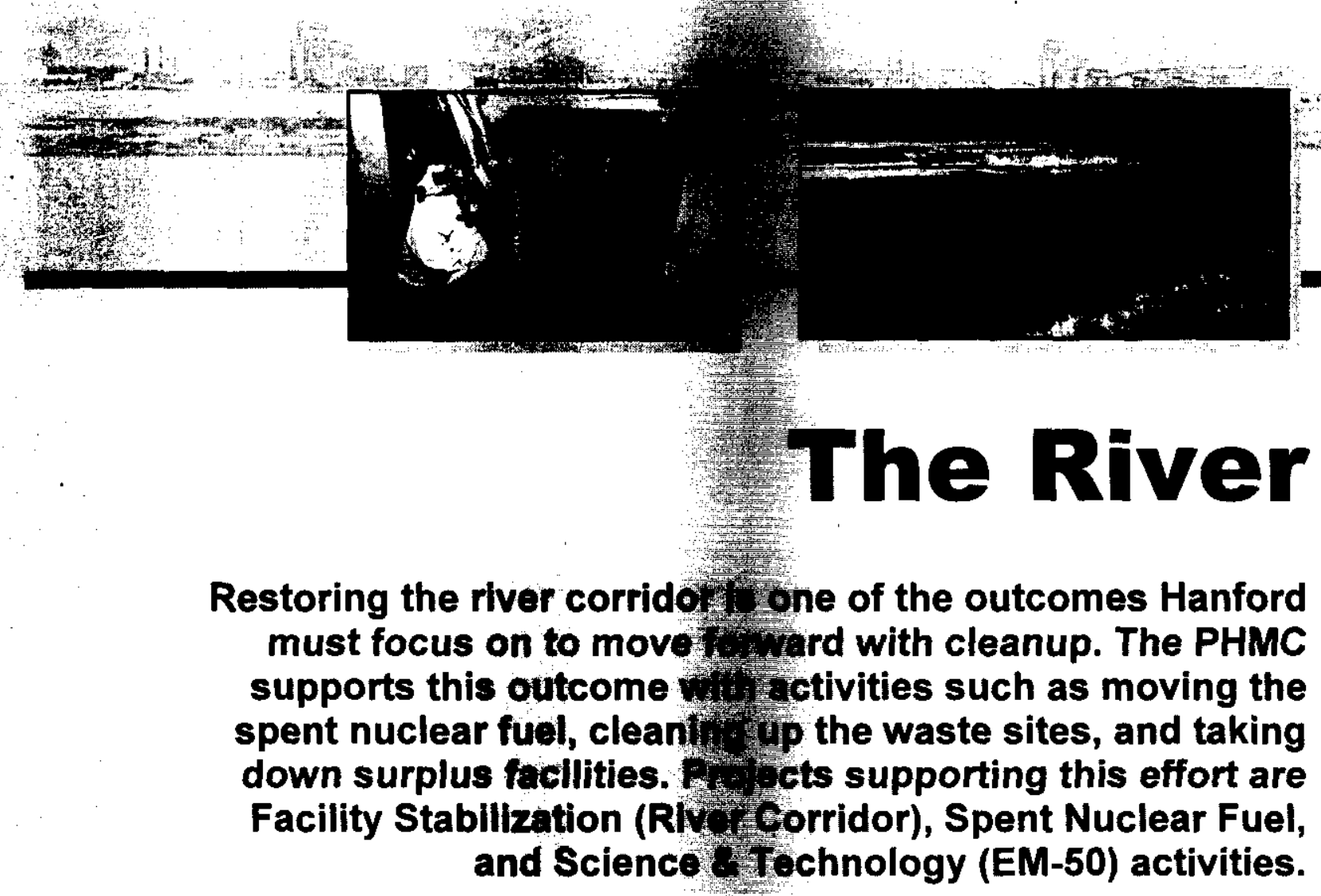




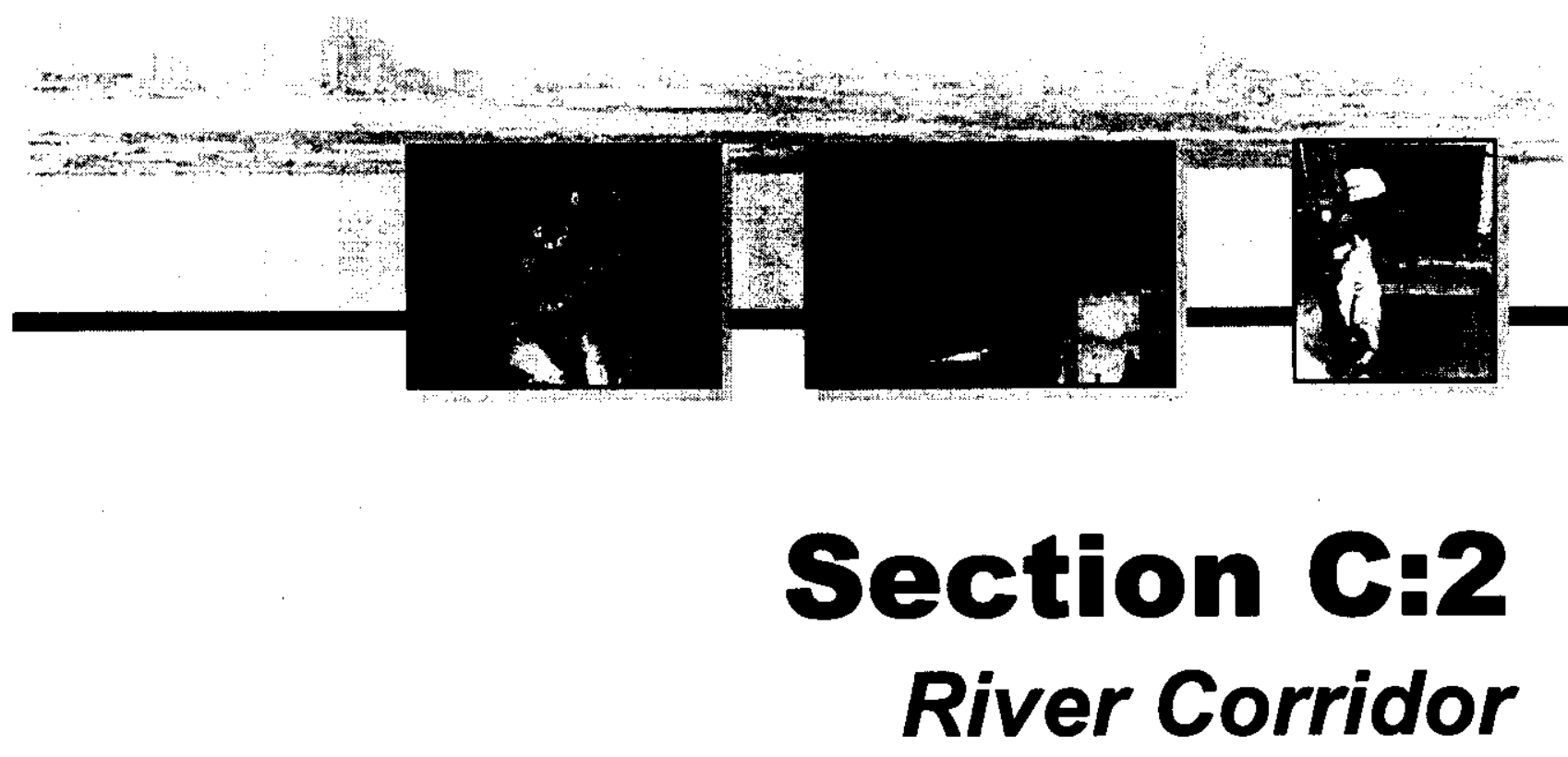

PROJECT MANAGERS

P.M. Knollmeyer, RL

(509) 376-7435

N. Boyter, FH (509) 373-3725 


\section{SUMMARY}

The River Corridor Project (RCP) consists of the following projects: 300 Area Liquid Effluent Facility (LEF) WBS 1.2.3.2, Project Baseline Summary (PBS) WM05; B-Plant, WBS 1.4.1, PBS TP01; 300 Area/Special Nuclear Materials, WBS 1.4.4, PBS TP04; Transition Project Management, WBS 1.4.6, PBS TP12; Accelerated Deactivation, WBS 1.4.8, PBS TP10; 324/327 Facility Transition, WBS 1.4.10, PBS TP08; and Hanford Surplus Facility Program (300 Area Revitalization), WBS 1.4.11, PBS TP14.

PBS WM05 is divided between WBS 1.2.3.1, Liquid Effluents (200 LEF) and WBS 1.2.3.2, 310 TEDF/340 Facility (300 LEF). The 310 TEDF/340 Facility work scope is now included in the River Corridor Project, whereas the Liquid Effluents (200 LEF) work scope has remained in Waste Management. For the purpose of performance analysis, PBS WM05 is reported in its entirety in the Waste Management Project, which has the majority of the work scope and funding incorporated in their baseline.

NOTE: Unless otherwise noted, the Safety, Conduct of Operations, Milestone Achievement, and Cost/Schedule data contained herein is as of October 31, 2000. All other information is as of November 29, 2000.

The 324 Building personnel conducted a vendor conference on the Spent Nuclear Fuel removal effort, shipped two truckloads of excess equipment and scrap from the outside storage area, and conducted load out of rectangular grout container-123 from B Cell. Additionally, the B Cell 3-ton crane repair, and the first phase of repair to the 30-Ton crane were completed. Staff also completed and tested the hammer drill designed and fabricated to break up the grout and allow disposition of grout container-88.

While in a min-safe mode, 327 Building personnel decontaminated two High Contamination Areas in the 327 basement and three in the canyon, and facility waste was sorted, scanned and compacted into eight low-level waste drums. In addition, a bulk waste box was removed from the canyon, waste buckets were moved from the cask into A Cell, and annual testing of Highefficiency particulate air (HEPA) filters (except for cell filters) was completed.

The 300 Area Treated Effluent Disposal Facility (TEDF) treated 5.63 million gallons of wastewater during October. TEDF personnel completed a four-day maintenance outage, and a significant cleanup effort at 340-A and 340-B was completed with the help of loaned resources from PFP. In addition, a new timesaving, no-cost data system was installed to extract data logs and prevent loss of information. The staff also completed the removal of the residual tank waste generated during the Process Sewer cleanout as planned.

The Accelerated Deactivation Project completed 3706 Building waste removal and lead paint cleanup at 222-T and 222-U. Additionally, personnel replaced a failed water separator and returned the 209-E purge air system to service. Detail work planning for initial 224-T process area entry and characterization commenced during this report period. 


\section{ACCOMPLISHMENTS}

- Decontaminated two High Contamination Areas in the 327 basement and three in the 327 canyon.

- Facility waste was compacted into eight low-level waste drums

- A bulk waste box was removed from the canyon

- Moved waste buckets into A Cell

- Completed testing of HEPA filter banks (except for cell filters).

- 300 Area/SNM completed

- Modifications to 333 Building electrical outlet configuration

- Uranium Disposition Project repackaging of four drums of uranium dioxide powder in preparation for shipment to the DOE Portsmouth site, in Ohio.

- The Accelerated Deactivation Project completed

- 3706 Building waste removal

- Lead paint cleanup at 222-T and 222-U

- Replacement of failed water separator and returned 209-E purge air system to service

- Commenced planning for initial entry and characterization of 224-T.

- The 300 Area Treated Effluent Disposal Facility

- Treated 5.63 million gallons of wastewater for October

- Completed a four-day maintenance outage

- Completed cleanup at 340-A and 340-B with the help of PFP loaned resources

- Installed new data system to extract data logs and prevent loss of information

- Completed the removal of residual tank waste from the Process Sewer cleanout.

- The 324 Building personnel

- Shipped two truckloads of excess equipment and scrap

- Conducted loadout of rectangular grout container-123 from B Cell

- Repaired B Cell 3-ton crane

- Completed and tested the hammer drill to break up grout in grout container-88

- Completed first phase of repair to the 30-Ton crane

- Conducted vendor conference on Spent Nuclear Fuel removal effort.

\section{SAFETY}

The project has exceeded 1,423,895 hours without a Lost Away Work Day Case (22 months, since January, 1999), as of November 17, 2000.

As of September, four OSHA recordable cases were recorded, breaking the run of no OSHA recordable cases since May 1999. One case was a report from June 1999 that reclassified to OSHA recordable, and there were three new cases in August. There were three first aid cases in October. The project had 726,000 hours between OSHA Recordable Cases, from August 1999 through July 2000 . The project has an overall green rating. 


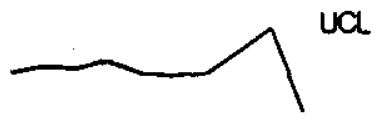

8

Average $=1.4$

(Mar 98 - Dec 98)

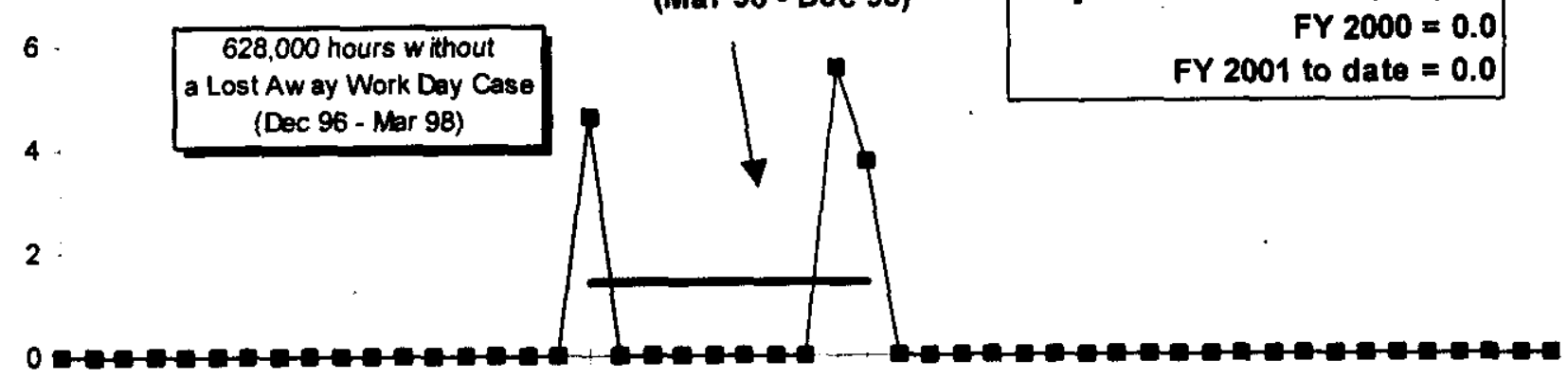

20 OSHA Recordable Case Rate
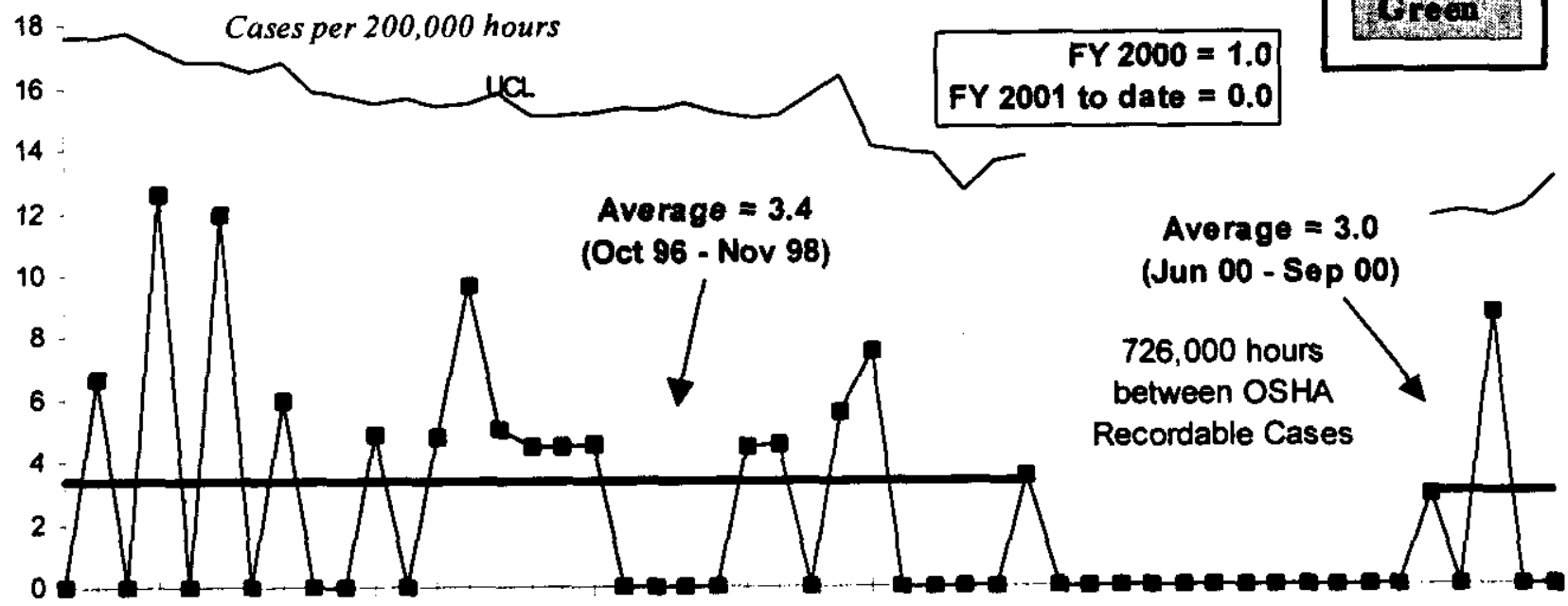

120 .

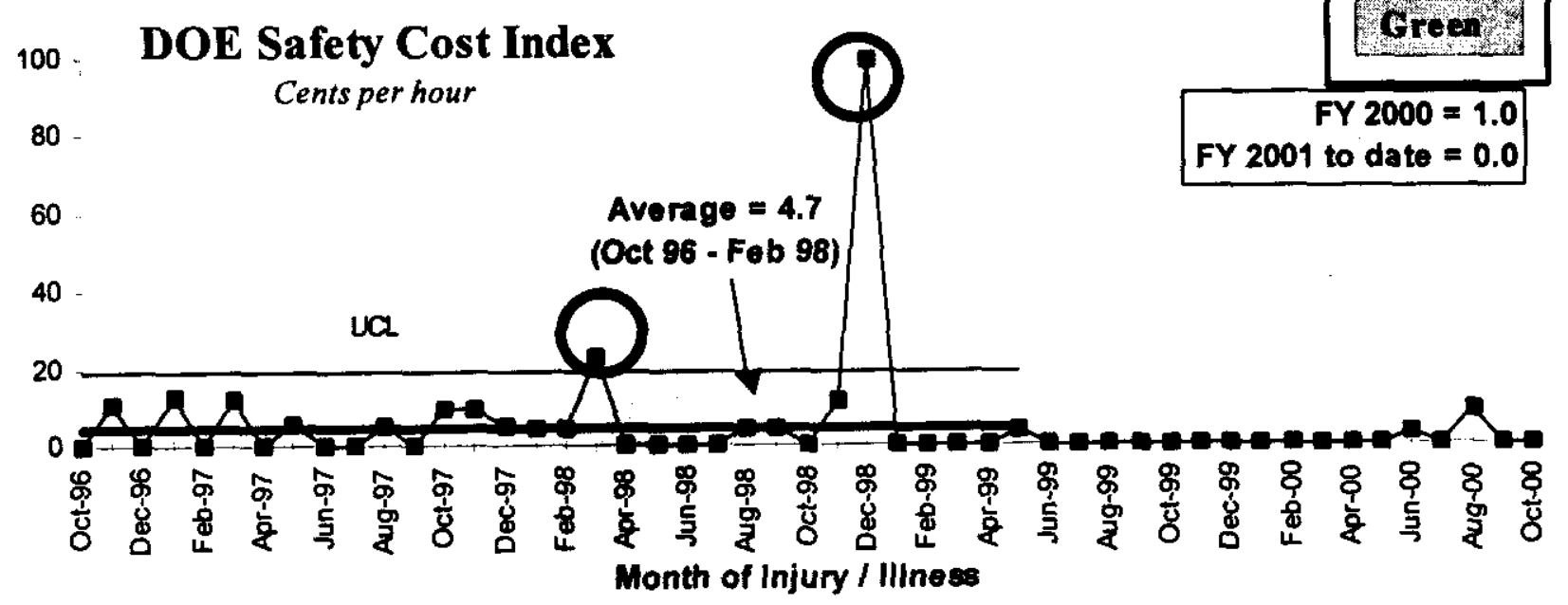




\section{CONDUCT OF OPERATIONS / ISMS STATUS}

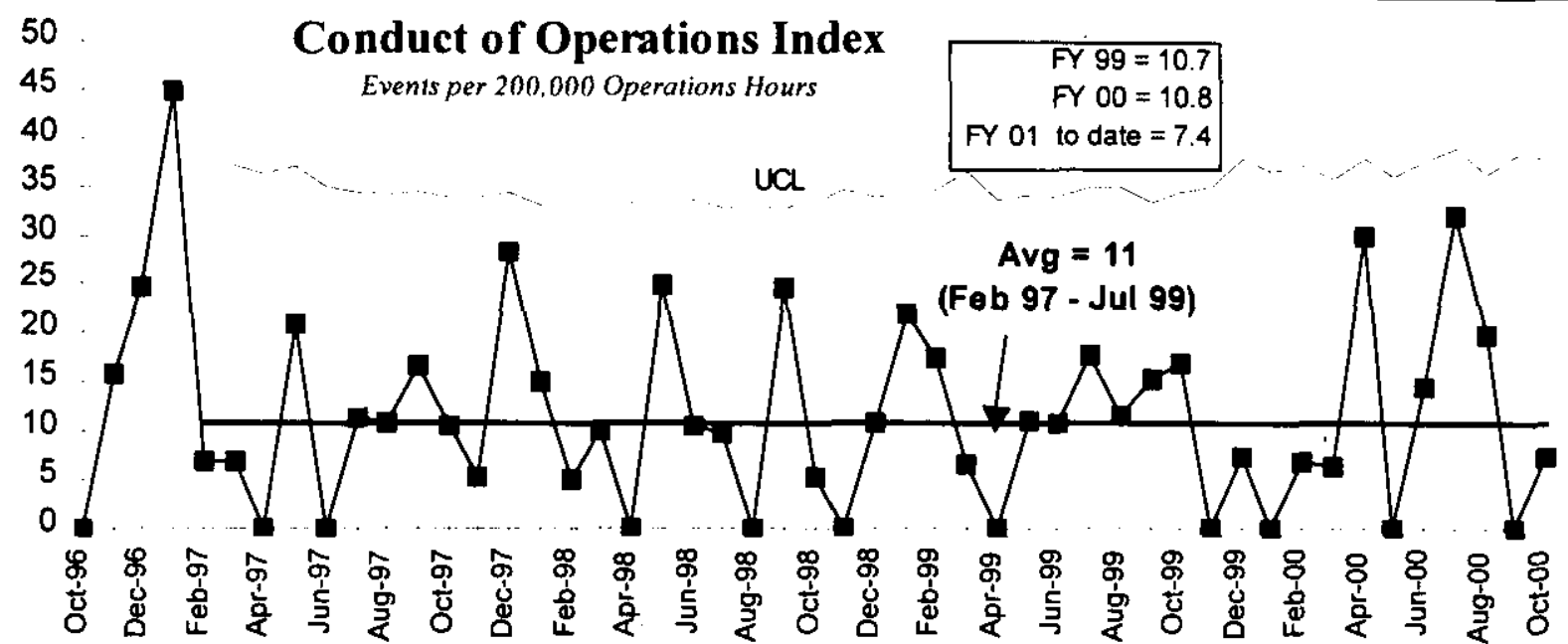

Number of Reports Past 12 Months

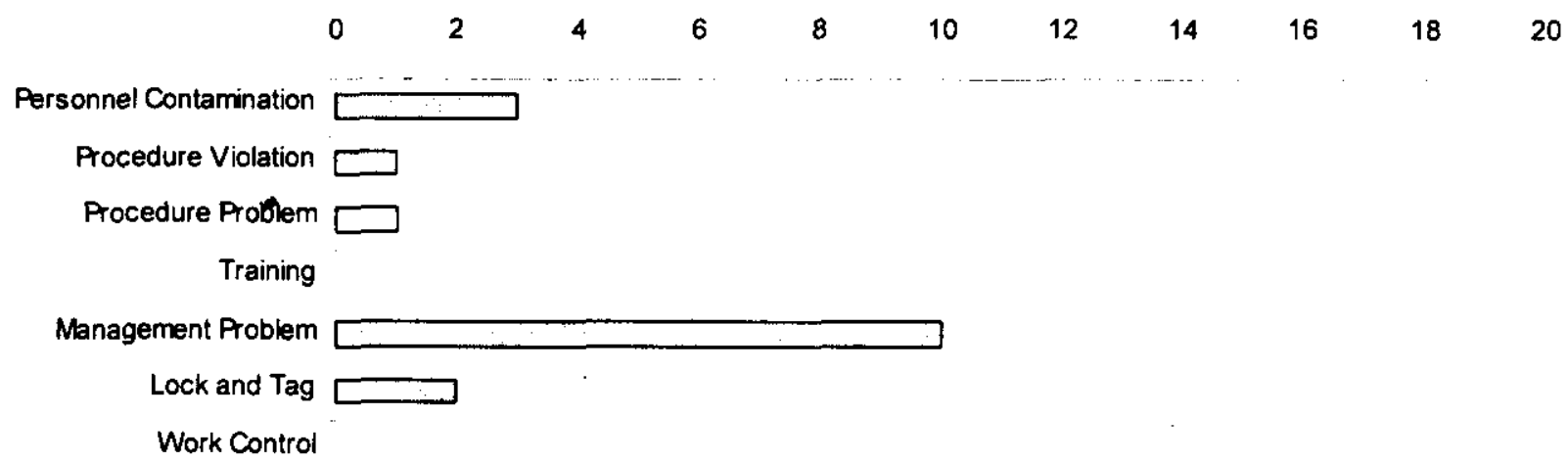

\section{ISMS STATUS}

- Results of the management assessment on the Automated Job Hazard Analysis have been provided to all individuals interviewed, the Integrated Safety Management System (ISMS) Center of Expertise and a Lessons Learned submitted.

- Eight members of the RCP work force will attend the National ISMS Workshop in December (four bargaining-unit and four exempt).

- RCP-MP-003 RCP Integrated Safety Management System Description was developed to reflect recent changes and properly align with the FH ISM description, and is being posted on the RCP website. 


\section{BREAKTHROUGHS / OPPORTUNITIES FOR IMPROVEMENT}

\section{Breakthroughs}

- 300 Area Accelerated Closure Plan - Based on the preparation of the 300 Area Accelerated Closure Plan an opportunity exists to accelerate closure of a significant portion of the 300 Area nearly four decades ahead of the current deactivation plan for an estimated savings of over $\$ 1.0$ billion. Provided basis for new "Done-in-a-Decade" closure project.

- Technical Reviews of 327 Hot Cell Removal - Technology Management, in conjunction with RCP, has submitted a draft proposal to the RCP for conducting a review of the feasibility of intact removal of hot cells from

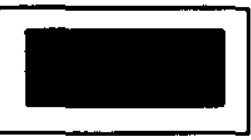
the 327 facility. Rather than perform hot cell decontamination, stabilization, size reduction, and utilization of standard waste packaging, the technical review would begin to evaluate the feasibility of stabilizing, packaging and disposing of the hot cell as whole units. The proposed technical review scope is now being evaluated by various RCP organizations, and should be finalized within the next few weeks.

\section{Opportunities for Improvement}

- 324 Project Planning / Execution - On November 7, 2000, FH provided formal notification to RL that Tri-Party Agreement milestone M-89-02 would be missed. FH, in concert with RL and the Washington State Department of Ecology (Ecology), is preparing a recovery schedule that factors in the schedule delays, and also predicts future schedule impacts. The schedule was impacted primarily due to technical/mechanical issues (30-ton crane repairs, 3-ton crane repairs) and needed operational improvements, as well as a reduction in the amount of overtime previously planned in the baseline schedule. Resolution of the higher bottom dose on the Steel Waste Disposal Boxes (SWDBs), although assumed to be resolved, as the schedule requires, also has the potential to significantly impact the schedule. FH is conducting workshop meetings with RL and Ecology and will issue a final schedule within the next month.

- Billet Safety Analysis Report for Packaging (SARP) - The Unirradiated Uranium Billet Safety Analysis Report for Packaging (SARP) is required to support shipment of uranium billets off-site. The current uranium billet

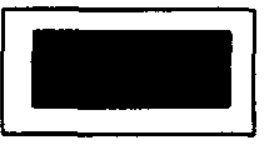
Safety Analysis Report for Packaging (SARP), Revision K, with a Certificate of Compliance (COC), allows shipment of only three billet boxes per trailer instead of five boxes per trailer that was analyzed for the revision. Shipping five boxes instead of three will save approximately $\$ 200 \mathrm{~K}$ of the billet transportation cost. DOE-HQ has been informed of the impact, and a COC for SARP HNF-SD-TP-SARP-019, Rev. 0 allowing five billet boxes per trailer is expected January $15,2001$. 


\section{UPCOMING ACTIVITIES}

Tri-Party Agreement Milestone M-89-02 - A tentative target date for completing the scope of "Complete removal of 324 Building Radiochemical Engineering Cell (REC) B Cell Mixed Waste (MW) and Equipment" is set for late March 2001.

Facility Evaluation Board Review - Complete Facility Evaluation Board review during first quarter of FY 2001.

324 / 327 Facility Authorization Basis - Implement technical update of 324 Authorization Basis (Safety Analysis Report) by December 2000, and implement technical update of 327 Authorization Basis (Basis of Interim Operation) by March 2001.

Uranium Disposition - Complete shipment of $\sim 235$ metric tons of excess uranium billets and $\sim 5$ metric tons of uranium dioxide to the DOE Portsmouth site in Ohio by March 31, 2001 and disposition of $\sim 140$ metric tons of surface-contaminated uranium fuel by June 30, 2001 (if funded).

324 B Cell Cleanup - Complete shipment of B Cell waste currently stored in A Cell to the 200 Areas by July $31,2001$.

224-T Facility - Begin 224-T initial entry and characterization by early March 2001.

\section{Cost Performance (\$M):}

\begin{tabular}{|l|c|c|c|}
\hline & BCWP & ACWP & VARIANCE \\
\hline River Corridor Project & $\$ 2.4$ & $\$ 1.0$ & $\$ 1.4$ \\
\hline
\end{tabular}

The $\$ 1.4$ million (60 percent) favorable cost variance is primarily from fiscal year startup anomalies. Further information at the PBS level can be found in the following Cost Variance Analysis details.

\section{SChedule Performance (\$M):}

\begin{tabular}{|l|c|c|c|}
\hline & BCWP & BCWS & VARIANCE \\
\hline River Corridor Project & $\$ 2.4$ & $\$ 3.2$ & $-\$ 0.8$ \\
\hline
\end{tabular}

The $\$ 0.8$ million (26 percent) unfavorable schedule variance is primarily due to Steel Waste Disposal Boxes (SWDB) hot spots issue and administrative actions. Further information at the PBS level can be found in the following Schedule Variance Analysis details. 


\section{Fy 2001 Cost/SChedule Performance - All Fund Types Cumulative to Date Status - (\$000)}

\begin{tabular}{ll} 
PBS TP01 & \multicolumn{1}{c}{ By-Plant } \\
WBS 1.4.1 & \\
PBS TP04 & 300 Area/ Special Nuclear \\
WBS 1.4.4 & Materials \\
PBS TP12 & Transition Program \\
WBS 1.4.6 & Management \\
PBS TP10 & Accelerated Deactivation \\
WBS 1.4.8 & \\
PBS TP08 & $324 / 327$ Facility Transition \\
WBS 1.4.10 & \\
PBS TP14 & Hanford Surplus Facility \\
WBS 1.4.11 & Program (300Area \\
& Revitalization) \\
& Total
\end{tabular}

\begin{tabular}{|c|c|c|c|c|c|c|c|c|c|c|c|c|c|}
\hline \multicolumn{2}{|c|}{ BCWS } & \multicolumn{2}{|c|}{ BCWP } & \multicolumn{2}{|c|}{ ACWP } & \multicolumn{3}{|c|}{ SV } & $\%$ & \multicolumn{2}{|c|}{ CV } & \multirow{2}{*}{$\%$} & PEM * \\
\hline s & - & & 0 & $\$$ & & s & - & & $0 \%$ & $\$$ & $(0)$ & & $\$$. \\
\hline s & 152 & $\$$ & 148 & $\$$ & (4) & $\$$ & & 4) & $.3 \%$ & $\$$ & 195 & $131 \%$ & 2.751 \\
\hline \$ & 413 & $\$$ & 414 & $\$$ & $(473$ & $\$$ & & 2 & $0 \%$ & $\$$ & 888 & $214 \%$ & $\begin{array}{ll}S \quad 6.917\end{array}$ \\
\hline \$ & 711 & $\mathbf{S}$ & 167 & \$ & 148 & & (54 & & $-77 \%$ & $s$ & 19 & $11 \%$ & 2,921 \\
\hline & 932 & $\$$ & 1.646 & \$ & 1,304 & & (28 & & $-15 \%$ & s & 341 & $21 \%$ & $\$ 35,394$ \\
\hline S & 25 & S & 21 & $\$$ & 20 & $\$$ & & 5) & $-18 \%$ & $\$$ & l & $4 \%$ & 416 \\
\hline
\end{tabular}

Notes: RL-Directed costs (steam and laundry) are included in the PEM BCWS. 310 TEDF/340 Facility performance data is reported under PBS WM05 (Waste Management)

\section{COST/SChedule PeRformance INDICES (MONTHLY AND FYTD)}

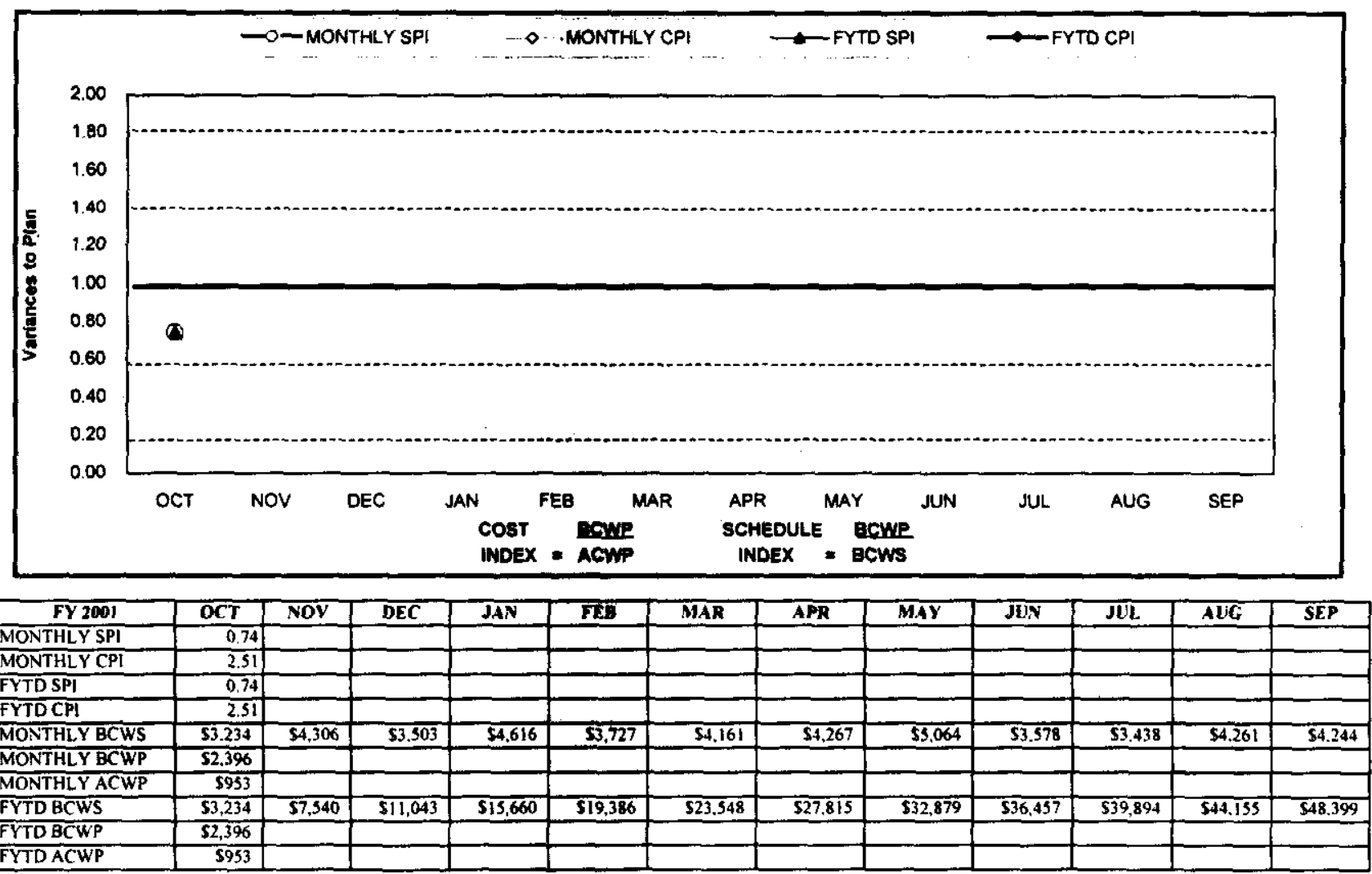




\section{COST VARIANCE ANALYSIS: $(+\$ 1.4 M)$}

\section{$\underline{\text { WBS/PBS } \quad \text { Title }}$}

\subsection{4/TP04 300 Area SNM}

Description and Cause: The favorable cost variance is primarily due to fiscal year startup anomalies. Specifically, reverse accrual entries related to FY00 yearend accruals are understating costs.

Impact: None.

Corrective Action: None.

\subsubsection{0/TP08 324/327 Facility Transition}

Description and Cause: The favorable cost variance is primarily due to fiscal year startup anomalies. Specifically, reverse accrual entries related to FY00 yearend accruals are understating costs.

Impact: None.

Corrective Action: None.

\subsection{8/TP10 Accelerated Deactivation}

Description and Cause: The favorable cost variance is primarily due to fiscal year startup anomalies. Specifically, reverse accrual entries related to FY00 yearend accruals are understating costs.

Impact: None.

Corrective Action: None.

\subsection{6/TP12 Transition Project Management}

Description and Cause: The favorable cost variance is primarily due to fiscal year startup anomalies. Specifically, reverse accrual entries related to FY00 yearend accruals are understating costs.

Impact: None.

Corrective Action: None.

All other PBS variances are within established thresholds.

\section{SCHEDULE VARIANCE ANALYSIS: (-\$0.8M)}

\subsubsection{0/TP08 324/327 Facility Transition}

Description and Cause: The unfavorable schedule variance is primarily due to the Steel Waste Disposal Boxes (SWDB) hot spots issue and the effect of plant work being put on hold while plant personnel were retrained and procedures strengthened.

Impact: TPA milestone M-89-02 will be delayed.

Corrective Action: Initial briefings with Ecology and RL have been completed. Recovery schedule is in development that moves completion of TPA milestone scope to March 2001. 


\subsection{8/TP10 Accelerated Deactivation}

Description and Cause: The unfavorable schedule variance is primarily due to a problem with the scheduling software data, which overstated BCWS.

Impact: None.

Corrective Action: The scheduling software problem has been identified and the correct data will be reflected in next month's reports.

\subsubsection{1/TP14 Hanford Surplus Facility Program (300A Revitalization)}

Description and Cause: The unfavorable schedule variance is primarily due to a problem with the scheduling software upload, which understated BCWP.

Impact: None.

Corrective Action: The scheduling software problem has been identified and the correct data will be reflected in next month's reports.

All other PBS variances are within established thresholds.

\section{ISSUES}

\section{Technical Issues}

Issue: 324 Building - Hot spots on the bottom of Steel Waste Disposal Boxes (SWDBs) loaded with Rectangular Grout Containers are more radioactive than the current Central Waste Complex (CWC) acceptance criteria of one rem per hour.

Impacts: Shipment schedule/in-cell work schedule has been delayed.

Corrective Action: Pursuing several actions:

- CWC is requesting an exception to EP-0063 to allow increased dose rates. This may require shielding provided by 324 Building at CWC.

- 324 Building is evaluating SWDB loading to optimize sequence of individual items to minimize dose rates.

\section{DOE/Regulator/External Issues}

Issue: On November 7, 2000, FH provided formal notification to RL that Tri-Party Agreement milestone M-89-02 would be missed.

Impacts: The schedule was impacted primarily due to technical/mechanical issues (30ton crane repairs, 3-ton crane repairs) and needed operational improvements, as well as a reduction in the amount of overtime previously planned in the baseline schedule. Resolution of the higher bottom dose on the Steel Waste Disposal Boxes (SWDBs), although assumed to be resolved, as the schedule requires, also has the potential to significantly impact the schedule.

Corrective Action: $\mathrm{FH}$, in concert with $\mathrm{RL}$ and Ecology, is preparing a recovery schedule that factors in the lost schedule, and also predicts future schedule impacts. $\mathrm{FH}$ is conducting workshop meetings with RL and Ecology and will issue a final schedule within the next month. 
Issue: Approval by DOE-HQ of the Unirradiated Uranium (UU) billet Safety Analysis Report for Packaging (SARP), Revision K, is requested to support shipment of uranium billets off-site. Impacts: DOE-HQ approved Revision K of the uranium billet Safety Analysis Report for Packaging (SARP) with a Certificate of Compliance (COC) that allows shipment of only three billet boxes per trailer instead of the 5 boxes per trailer that was analyzed in the revision. Using this COC will increase the billet transportation cost by approximately $\$ 200 \mathrm{~K}$.

Corrective Action: DOE-HQ has been informed of the impact, and a COC allowing five billet boxes per trailer is expected by January 15, 2001 .

Issue: An opportunity exists for transfer of Pacific Northwest National Laboratory (PNNL) facilities into PBS TP-14, pending resolution of the current DOE-HQ guidance to EM (pipeline suspension). PNNL has funds for FY 2001/2002 Surveillance and Maintenance (S\&M) identified for transfer to $\mathrm{FH}$, but these funds may no longer be available when the suspension ends.

Impacts: Efficiencies realized through combining these facilities into PBS TP-14 may be jeopardized.

Corrective Action: PNNL has drafted a Memorandum of Agreement (MOA) to define a path forward. The PNNL MOA has been reviewed by FH, RL, and comments incorporated. DOE-HQ has been briefed on the transfer. Resolution of the pipeline suspension issue is expected in December 2000.

\section{Baseline Chance Requests Currently in Process $(\$ 000)$}

\begin{tabular}{|c|c|c|c|c|c|c|c|c|c|}
\hline $\begin{array}{l}\text { PROJECT } \\
\text { CHANGE } \\
\text { NUMBER } \\
\end{array}$ & $\begin{array}{c}\text { DATE } \\
\text { ORIGIN. }\end{array}$ & BCR TITE & $\begin{array}{c}\text { COST } \\
\text { IMPACT } \\
\text { S000 } \\
\end{array}$ & $\begin{array}{l}\mathrm{s} \\
\mathrm{c} \\
\mathrm{H}\end{array}$ & $\begin{array}{l}\mathrm{T} \\
\mathrm{E} \\
\mathrm{C} \\
\mathrm{H}\end{array}$ & $\begin{array}{c}\text { DATE TO } \\
\text { CCB } \\
\end{array}$ & $\begin{array}{c}\mathrm{CCB} \\
\mathrm{APR} \mathrm{R}^{\prime} \mathrm{D} \\
\end{array}$ & RL. APR'VD & CURRENT STATUS \\
\hline FSP-2000-002 & $11 / 2 / 99$ & Mark-42 Project Completion & $\$ 304$ & & $\mathrm{x}$ & $04 / 05 / 00$ & & & Additional funding req'd \\
\hline FSP-2000-072 & $7 / 27 / 00$ & MrWP Submittal (Phase I) & $(\mathbf{5 3 7 , 7 6 7 )}$ & $\mathrm{x}$ & $x$ & $08 / 25 / 00$ & $08 / 31 / 00$ & & Pending RL Approval \\
\hline FSP-2000-084 & $8 / 31 / 00$ & Transfer 209E facility & $\$ 526$ & & $\mathrm{x}$ & $09 / 14 / 00$ & $09 / 14 / 00$ & $10 / 17 / 00$ & \\
\hline $\mathrm{FH}-2000-001$ & $9 / 1200$ & Base Ops Reduction for PHMC Projects & $(\$ 2.575)$ & & $x$ & & & & Draft Prepared \\
\hline FH-2000-002 & $9 / 25 / 00$ & FY200I Fee Reduction to $90 \%$ & $(\$ 413)$ & & & & & & Draft Preparod \\
\hline $\mathrm{FH}-2000-003$ & $9 / 25 / 00$ & FY200I Addn of High Priority Workscope & $\$ 14.951$ & & $x$ & & & & Draft Prepared \\
\hline FSP-2001-001 & $10 / 900$ & Baseline Adjustment to TP08 & $(\mathbf{5 4 9 )}$ & & $\mathbf{x}$ & & & & Draft Prepared \\
\hline FSP-2001-007 & $10 / 31 / 00$ & Uranium Disposition Project & $\$ 371$ & & $x$ & $11 / 7 / 00$ & & & Pending FH Board Review \\
\hline FSP-2001-008 & $11 / 7 / 00$ & FY2001 Savings Opportunities & $(\$ 607)$ & & $x$ & $11 / 15 / 00$ & & & Pending FH Board Review \\
\hline FSP-2001-011 & $11 / 14 / 00$ & Design Change - 324 LWHS & so & & $\mathrm{x}$ & & & & Draft Prepared \\
\hline \multicolumn{10}{|c|}{ ADVANCE WORK AUTHORIZATIONS } \\
\hline AWA & $10 / 2 / 00$ & FY01 Uranium Disposition Activities & $\$ 371$ & & $\mathrm{x}$ & $10 / 3 / 00$ & $10 / 18 / 00$ & $10 / 18 / 00$ & BCR \#FSP-2001-007 \\
\hline AWA & $11 / 2 / 00$ & 324 SAR & $\$ 56$ & & $\mathrm{x}$ & $11 / 3 / 00$ & $11 / 3 / 00$ & $11 / 3 / 00$ & \\
\hline
\end{tabular}




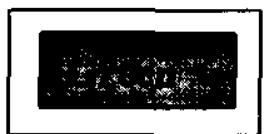

\begin{tabular}{|c|c|c|c|c|c|c|c|c|}
\hline \multirow[b]{2}{*}{ MILESTONE TYPE } & \multicolumn{4}{|c|}{ FISCAL YEAR-TO-DATE } & \multicolumn{3}{|c|}{ REMAINING SCHEDULED } & \multirow[b]{2}{*}{$\begin{array}{l}\text { TOTAL } \\
\text { FY } 2001\end{array}$} \\
\hline & $\begin{array}{c}\text { Completed } \\
\text { Early }\end{array}$ & $\begin{array}{c}\text { Completed } \\
\text { On } \\
\text { Schedule }\end{array}$ & $\begin{array}{c}\text { Completed } \\
\text { Late }\end{array}$ & Overdue & $\begin{array}{c}\text { Forecast } \\
\text { Early }\end{array}$ & $\begin{array}{c}\text { Forecast } \\
\text { On } \\
\text { Schedule }\end{array}$ & $\begin{array}{c}\text { Forecast } \\
\text { Late }\end{array}$ & \\
\hline Enforceable Agreement & o & 0 & 0 & $\overline{0}$ & 0 & 0 & 1 & 1 \\
\hline DOE-HQ & 0 & 0 & 0 & 0 & 0 & 2 & 0 & 2 \\
\hline$R L$ & 0 & 0 & 0 & 0 & 0 & 9 & 0 & 9 \\
\hline Total Project & 0 & 0 & 0 & 0 & 0 & 11 & 1 & 12 \\
\hline
\end{tabular}

Only TPA/EA milestones and all FY 2001 overdue and forecast late milestones are addressed in this report. Milestones overdue are deleted from the Milestone Exception Report once they are completed. The following chart summarizes the FY 2001 TPA/EA milestone achievement and a Milestone Exception Report follows. The last milestone table summarizes the first six months of FY 2002 TPA/EA milestones.

\begin{tabular}{|l|l|l|}
\hline \multicolumn{3}{|c|}{ FY 2001 Tris } \\
\hline $\begin{array}{l}\text { M-89-02 } \\
\text { (TRP-99-901), }\end{array}$ & $\begin{array}{l}\text { "Complete Removal of 324 } \\
\text { Building Radiochemical } \\
\text { Engineering Cells (REC) B } \\
\text { Cell Mixed Waste (MW) } \\
\text { and Equipment," }\end{array}$ & $\begin{array}{l}\text { Due 11/30/00 - Progress } \\
\text { continues to be made in } \\
\text { accomplishing the milestone } \\
\text { work scope, however due to technical and } \\
\text { operational issues the milestone will not be met. } \\
\text { A recovery schedule is being developed with the } \\
\text { support of RL and Ecology. }\end{array}$ \\
\hline $\begin{array}{l}\text { MX-92-06- } \\
\text { T01 (TRP-01- } \\
\text { 108) }\end{array}$ & $\begin{array}{l}\text { "Complete Disposition for } \\
\text { all Site Unirradiated } \\
\text { Uranium" }\end{array}$ \\
\hline \multicolumn{3}{|c|}{ DNFe 12/29/00 - On Schedule. } \\
\hline \multicolumn{3}{|c|}{} \\
\hline
\end{tabular}

\section{MILESTONE EXCEPTION REPORT}

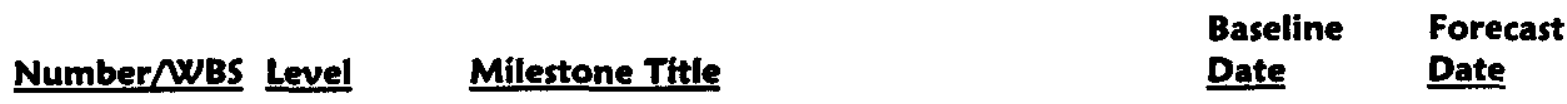

\section{FORECAST LATE - 1}

TRP-99-901 EA

\section{4 .10}

Complete Removal of 324 Radiochemical Engineering Cells (REC) B Cell Mixed Waste (MW) \& Equip.
$11 / 30 / 00 \quad 03 / 30 / 01$

Cause: Technical and operational issues have delayed completion of this work scope.

Impact: Completion of TPA milestone M-89-02 will not be met.

Corrective Action: A recovery schedule has been developed with the support of RL and Ecology. 


\section{FY 2000 OVERDUE - 1}

TRP-99-933 RL Containerize Dispersible Under 2A Rack $\quad 04 / 30 / 00 \quad 03 / 30 / 01$

1.4.10

Cause: It has been determined it is more efficient to complete dispersible collection after the waste containers in the cell are removed.

Impact: No impact. This milestone will complete with M-89-02.

Corrective Action: No corrective action is required.

\begin{tabular}{|c|l|l|}
\hline \multicolumn{3}{|c|}{ FY 2002 Tri-Party Agreement / EA Milestones } \\
\hline & Nothing to report at this time & \\
\hline \multicolumn{2}{|c|}{ DNFSB Commitments } \\
\hline & Nothing to report at this time. & \\
\hline
\end{tabular}

Performance Objectives

\begin{tabular}{|c|c|c|}
\hline Outcome & Performance Indicator & Status \\
\hline \multirow{2}{*}{$\begin{array}{l}\text { Restore } \\
\text { the River } \\
\text { Corridor } \\
\text { for } \\
\text { Multiple } \\
\text { Uses }\end{array}$} & $\begin{array}{l}\text { FDH-RC-2 } \\
324 / 327 \text { Deactivation }\end{array}$ & $\begin{array}{l}\text { At risk - FH provided formal notification to RL that Tri- } \\
\text { Party Agreement milestone } \mathrm{M}-89-02 \text { would be missed. } \\
\mathrm{FH} \text {, in concert with RL and Ecology, is preparing a } \\
\text { recovery schedule that factors in the lost schedule, and } \\
\text { predicts future schedule impacts. }\end{array}$ \\
\hline & $\begin{array}{l}\text { FDH-RC-3 } \\
\text { Disposition } 200 \& 300 \text { Area Uranium }\end{array}$ & On track. \\
\hline
\end{tabular}

\section{KEY INTEGRATION ACTIVITIES}

- National Facility Deactivation Initiative (NFDI) Support to DOE Complex - Continued implementation of National Facility Deactivation Initiative (NFDI) DOE-complex key objectives. These may include: 1) Exchange technical assistance and lessons learned with other DOE sites and NFDI technical support, 2) Assist in implementing the NFDI communication and marketing objectives, and 3) Advance facility disposition at Hanford by increasing NFDI's exposure and participation.

- 324 Building/SNF Project Savings - In FY 2000, the River Corridor Project (RCP) 324 Building B Cell project, along with the Spent Nuclear Fuel (SNF), developed an alternative plan for the fuel removal activity. Agreement to use a longer inner canister for the fuel permits greater end shielding and allows manual welding and testing in the Cask Handling Area (CHA), rather than the more expensive remote effort in B Cell. The Programmatic Agreement, which outlines the responsibilities and general items for this fuel transfer, was approved by both RCP and SNF on October 6, 2000. The 200 Area Interim Storage Area Acceptance Criteria (HNF-4894) is undergoing final review and comment by RCP. 
Comments were forwarded to SNF, incorporated, and began routing for final approval by RCP and SNF on November 21, 2000. Approval is expected by December 1, 2000.

- EM-50 Support - With support from EM-50, AEA Technology completed two draft reports regarding future RCP deactivation tasks: (1) Option Study for Inspection, Sampling and Remediation for Tank T-105 in the HLW Vault in Building at Hanford; and (2) Options Study for B Cell HVAC Duct Remediation. A final report on the T-105 study was received mid-November, however a revision is expected. A report has not yet been received on the duct study. Other topics proposed by RCP for 2001 funding are:

- Demonstration and Deployment of the AEA Artisan-100 Arm for Hot Cell Deactivation

- Options Study on Intact Removal and Disposal of 327 Facility Hot Cells

- Dry Decontamination of 327 Hot Cell

- 340 Vault Tank Heel Removal

DOE-HQ is in the process of prioritizing all projects suggested for assignment to AEA Technology.

- New Hainford-Rocky Flats-Savannah River Joint Deactivation Proposal - Through involvement with NFDI, Hanford, Rocky Flats, and Savannah River in FY 2000, a joint proposal focused on demonstration and deployment of large equipment size reduction systems was completed and submitted. In anticipation of approval, RCP and the FH Technology Management organization met with PAR Systems to preview the glovebox size reduction system that is being developed for the Rocky Flats site. PAR Systems is supporting a contract that was awarded to Oceaneering International, Inc, to deliver a glovebox size reduction system for the Rocky Flats site. This is an ex-situ system that is scheduled to begin operation in the fall of 2001. Hanford should benefit from the experience gained at Rocky Flats over the next several years.

- Participation in West Valley Demonstration Project - In FY 2000 RCP issued a letter of support to DOE-RL to participate as a "non-host deployment site" in a proposal led by PNNL Technology Development and West Valley. The West Valley (NY) Demonstration Project is deactivating hot cell facilities with similar decontamination and decommissioning challenges to RCP facilities. The project would fund $\mathrm{FH}$ on an Integrated Contractor Team (ICT). The ICT will influence the identification and selection of technologies. Based on successful demonstration at West Valley, FH will consider the best technologies for use at RCP. Nine proposals from throughout the DOE-Complex were submitted in response to EM-50's Large Scale Demonstration and Deployment Program call for proposals, with FH involvement in three of the nine.

- Coordination With the 324 B Cell Cybernetix Procurement Project Team - PNNL staff have begun interfacing on a regular basis with the 324 Building staff regarding dealings with Cybernetix. Both companies have current contracts with Cybernetix. A PNNL staff member is now attending the $\mathrm{B}$ Cell conference calls with Cybernetix, and data transmittals of pertinent information will be made between PNNL and RCP. Discussions regarding tool handles and cold test tooling have also begun to determine if the two projects can cost share. 


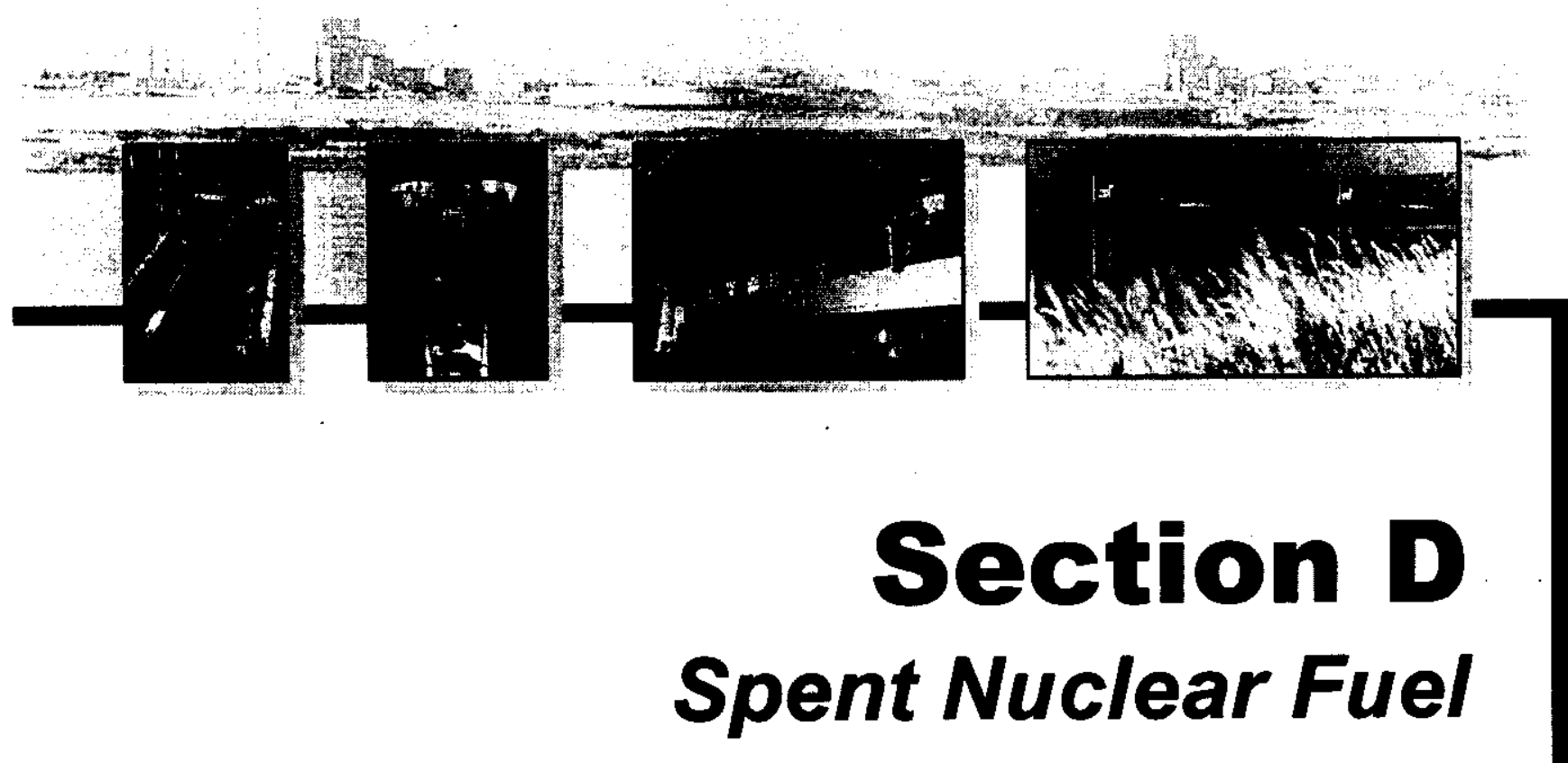

PROJECT MANAGERS P.G. Loscoe, RL (509) 373-7465

J.H. Wicks Jr., FH (509) 373-9372 


\section{SUMMARY}

The Spent Nuclear Fuel (SNF) mission consists of the Spent Nuclear Fuel Project WBS 1.3.1.1 (Project Baseline Summary [PBS] WM01) and the subsequent Canister Storage Building (CSB) Operations Project WBS 1.3.2.1 (PBS WM02), which does not start until FY 2004.

NOTE: Unless otherwise noted, the Safety, Conduct of Operations, Milestone Achievement, and Cost/Schedule data contained herein is as of October 31,2000. All other information is as of November 24, 2000.

Fiscal year-to-date milestone performance (EA, HQ, and RL) shows that two out of five milestones ( 40 per cent) are overdue.

The Milestone Achievement details, found following the cost and schedule variance analysis, provide further information on all milestone types.

\section{ACCOMPLISHMENTS}

- Successfully completed DOE Operational Readiness Review (ORR) on the Canister Storage Building (CSB), K West (KW) Basin, and Project transportation systems on November 16, 2000 and completed the Contractor ORR for the Cold Vacuum Drying (CVD) Facility on November 24, 2000. Overall, there were 13 pre-start findings, 11 post-start findings, and 4 observations. Under Noteworthy Practices the DOE ORR Team stated:

- The SNF Project has done a good job of managing the S/RID program

- The SNF Project has done a good job promoting safety

- The SNF Project QA inspectors are qualified in inspection methods

The pre-start findings have been addressed and post-start findings are being addressed.

- Completed loading of the first six Multi-Canister Overpack (MCO) fuel baskets and placed in the queue; awaiting authorization to place into first production MCO.

- Successfully performed two million safe hours without a lost time accident. The new Spent Nuclear Fuel (SNF) Project record comes after two previous one million safe hour records were achieved during the period between April 1999 and April 2000.

- Over the past two years the SNF Project and RL have been working with the Defense Nuclear Facilities Safety Board (DNFSB) on several technical issues that were not fully resolved. The DNFSB listed these issues in a letter to RL dated September 2000. In response the SNF Project and RL prepared a detailed response and met with DNFSB Staff. All remaining technical issues with DNFSB Staff have now been resolved.

\section{SAFETY}

The project has achieved over 2,000,000 safe work hours on November 15, 2000. No Lost Away Workday Cases have been reported in the last twelve months. SNF OSHA recordable case rate for FY 2000 was 2.3 , higher that the FH goal of 0.9 . 
PHMC Environmental Management Performance Report-December 2000 Section D-Spent Nuclear Fuel

7
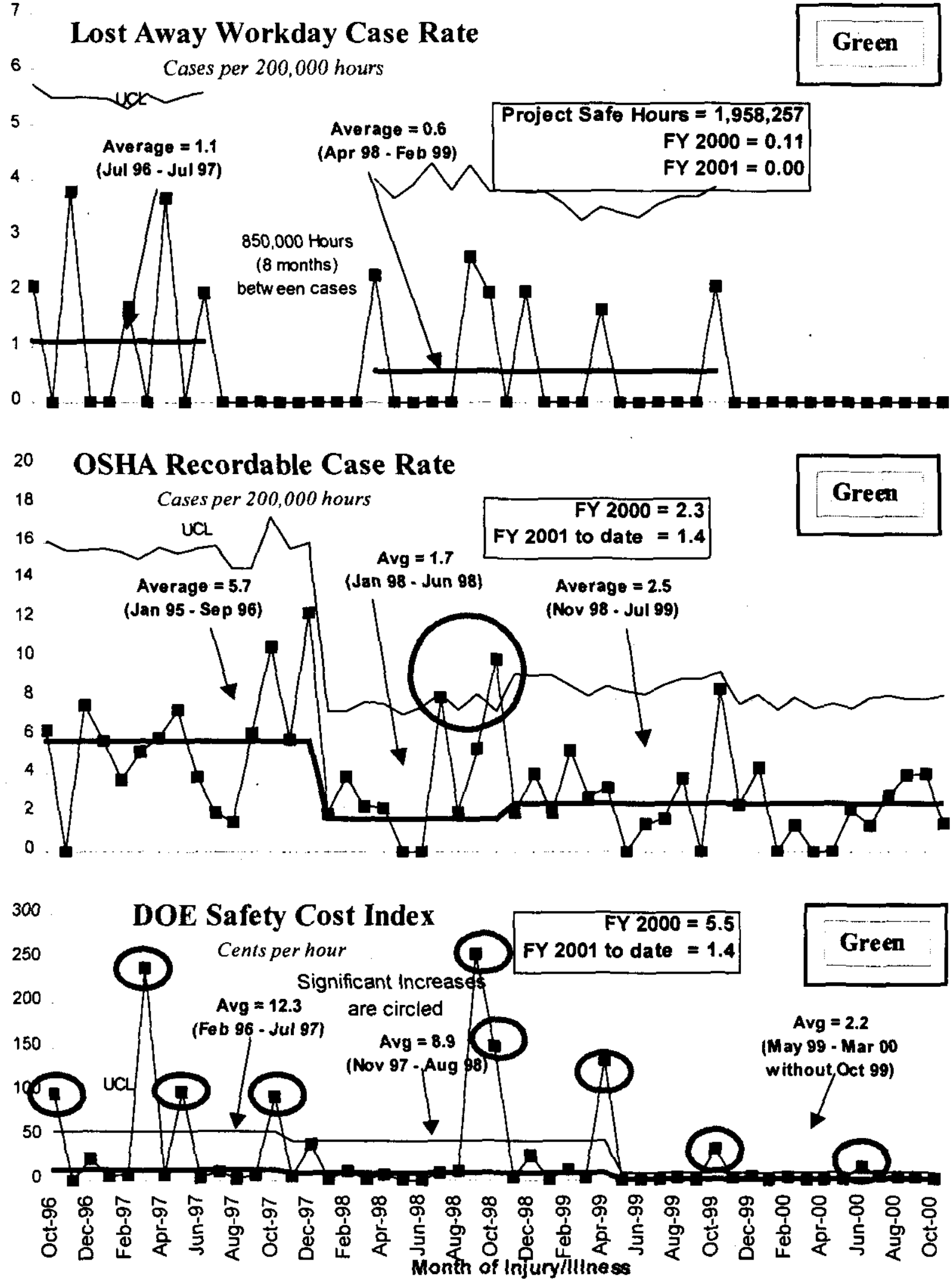


\section{CONDUCT OF OPERATIONS / ISMS STATUS}

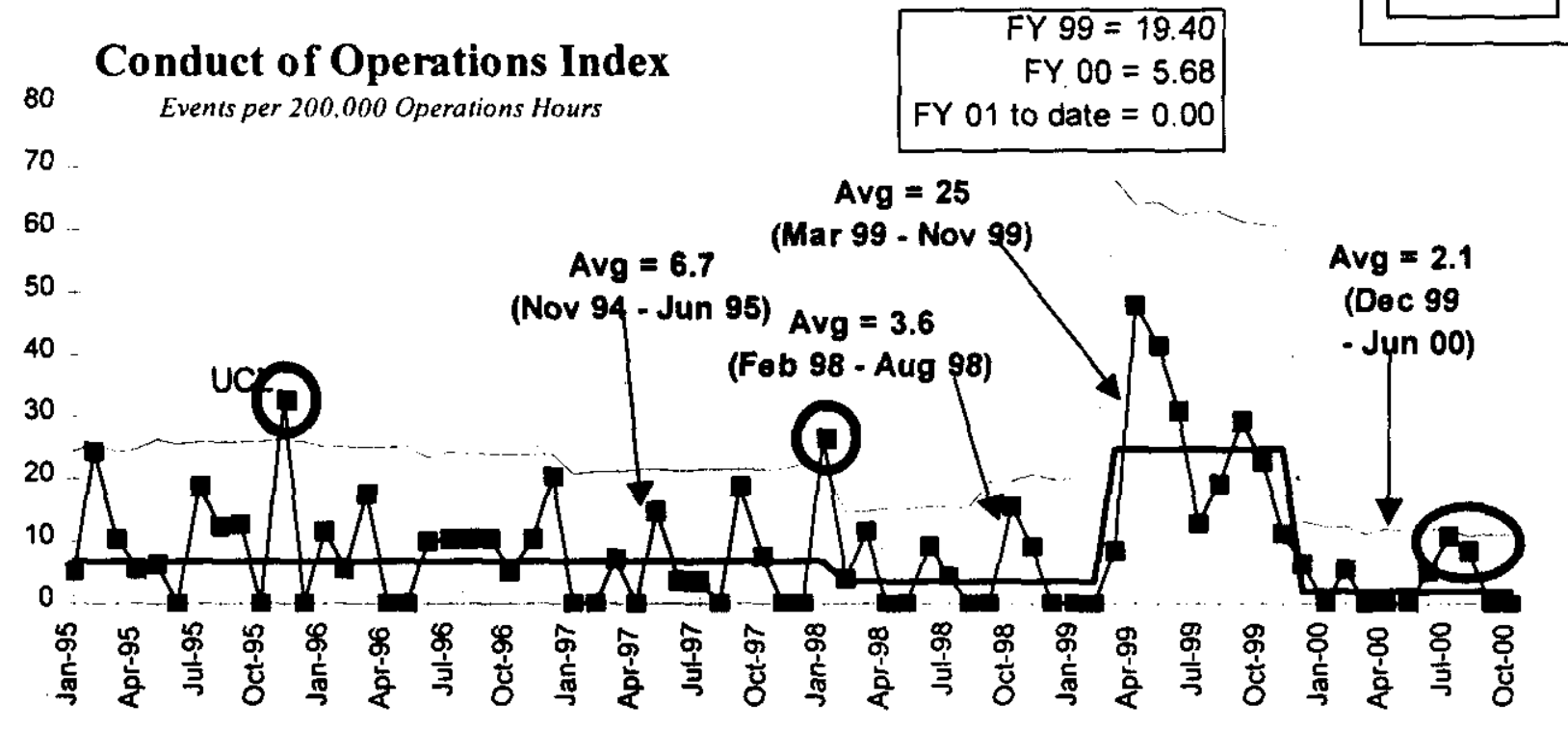

\section{Number of Reports Past 12 Months}

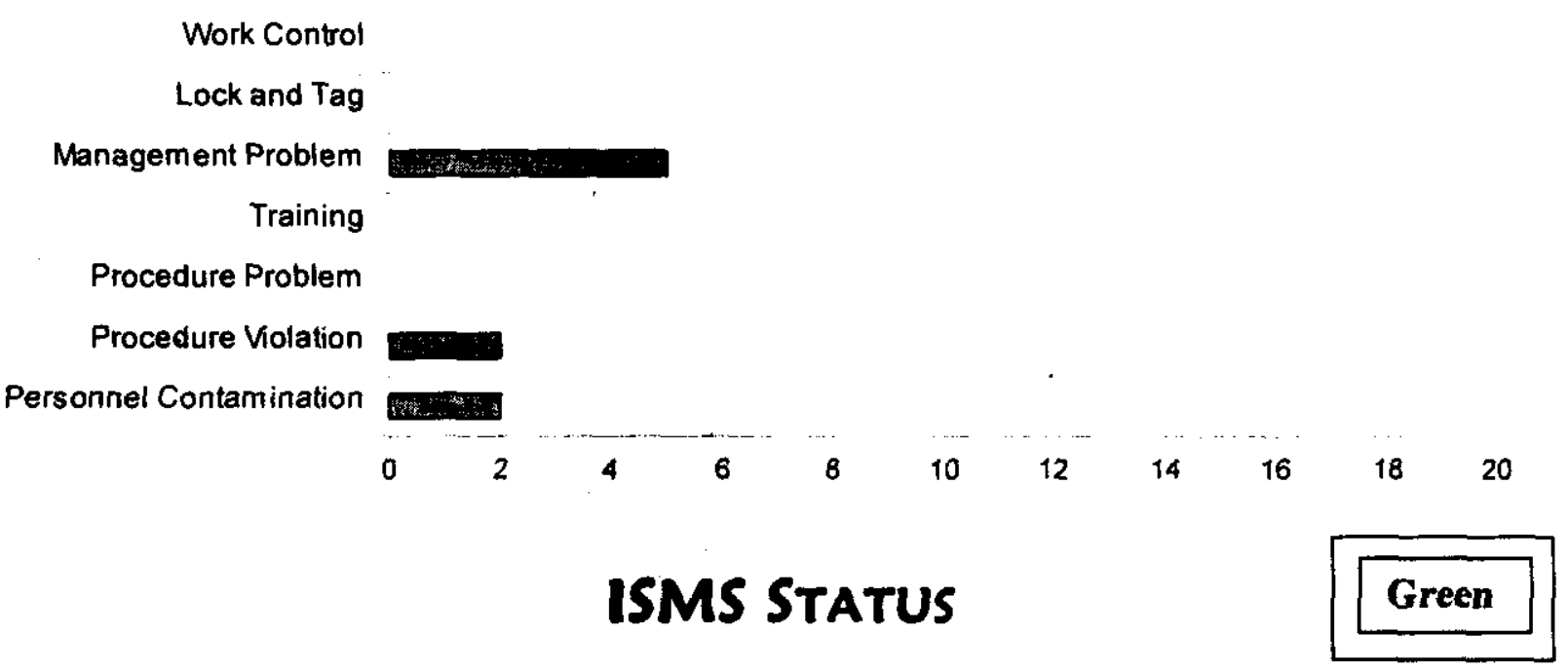

- Performed management assessment of SNF Project Integrated Safety Management System (ISMS) performance for FY2000 that demonstrated the SNF Project is satisfactorily performing to the ISMS Core Functions (CF) and Guiding Principles (GP). Report issued October 16, 2000.

- Project Director issued FY2001 Management Assessment Plan that has each assessment topic linked to an ISMS CF or GP. Specific direction provided to ensure each management assessment report has a section that specifically discusses the ISMS CF or GP and includes a performance conclusion. Plan issued November 2, 2000.

- SNFP personnel participated in Project Hanford Management Contract (PHMC) ISMS Center of Expertise activities of developing PHMC ISMS Sustain and Maintain Plan for FY2001. 


\section{BREAKTHROUGHS / OPPORTUNITIES FOR IMPROVEMENT}

\section{Breakthroughs}

Nothing to report at this time.

\section{Opportunities for Improvement}

The Alternative Fuel Transfer Strategy (AFTS) will move fuel from the K East (KE) basin to the $\mathrm{K}$ West $(\mathrm{KW})$ basin for processing in lieu of processing fuel in the $\mathrm{KE}$ basin as currently baselined. This strategy will reduce worker radiation exposure, safety risks, and increases the confidence level that the life cycle cost and schedule objectives can be achieved.

\section{UPCOMING ACTIVITIES}

- Complete RL Operational Readiness Review for Canister Vacuum Drying (CVD) Facility in November 2000.

- Begin KW Basin fuel removal, drying and storage operations in November 2000.

- Submit Tri-Party Agreement (TPA) Change Request for Milestone M-34-06-T01 "Initiate K West Basin spent nuclear fuel canister cleaning operations" December 2000.

- Continue receipt of Multi-Canister Overpack (MCO) shipments through FY 2001.

- Submit Annual Debris Report to Department of Ecology/Environmental Protection Agency (EPA) in May 2001.

\section{Cost Performance (\$M):}

\begin{tabular}{|l|c|c|c|}
\hline & BCWP & ACWP & VARIANCE \\
\hline Spent Nuclear Fuel & $\$ 7.3$ & $\$ 9.8$ & $-\$ 2.4^{*}$ \\
\hline
\end{tabular}

Rounding

The unfavorable cost variance of $\$ 2.4$ million ( 33 percent) is due to additional facility start up and engineering required to resolve first-of-a-kind equipment issues at $\mathrm{K}$ Basins and the CVD Facility and subsequent extension of the Operational Readiness Review process.

\section{SCHedule Performance (\$M):}

\begin{tabular}{|l|c|c|c|}
\hline & BCWP & BCWS & VARIANCE \\
\hline Spent Nuclear Fuel & $\$ 7.3$ & $\$ 7.3$ & $\$ 0.0$ \\
\hline
\end{tabular}

There is no schedule variance. 


\section{FY 2001 Cost/Schedule Performance - All Fund Types Cumulative to Date Status - $(\$ 000)$}

FYTD

$\begin{array}{llllllllll}\text { By PBS } & \text { BCWS } & \text { BCWP } & \text { ACWP } & \text { SV } & \% & \text { CV } & \% & \text { PEM }\end{array}$

\begin{tabular}{lllllllllll} 
PBS WM01 & $\begin{array}{l}\text { Spent Nuclear } \\
\text { WBS 1.3 }\end{array}$ & Fuel Project & $\$ 7,302$ & $\$ 7,317$ & $\$ 9,757$ & $\$ 16$ & $0 \%$ & $\$(2,440)$ & $-33 \%$ & $\$ 189,761$ \\
\cline { 2 - 8 } & Total & $\$ 7,302$ & $\$ 7,317$ & $\$ 9,757$ & $\$ 16$ & $0 \%$ & $\$(2,440)$ & $-33 \%$ & $\$ 189,761$
\end{tabular}

\section{Cost/Schedule Performance Indices (MONTHLY AND FYTD)}

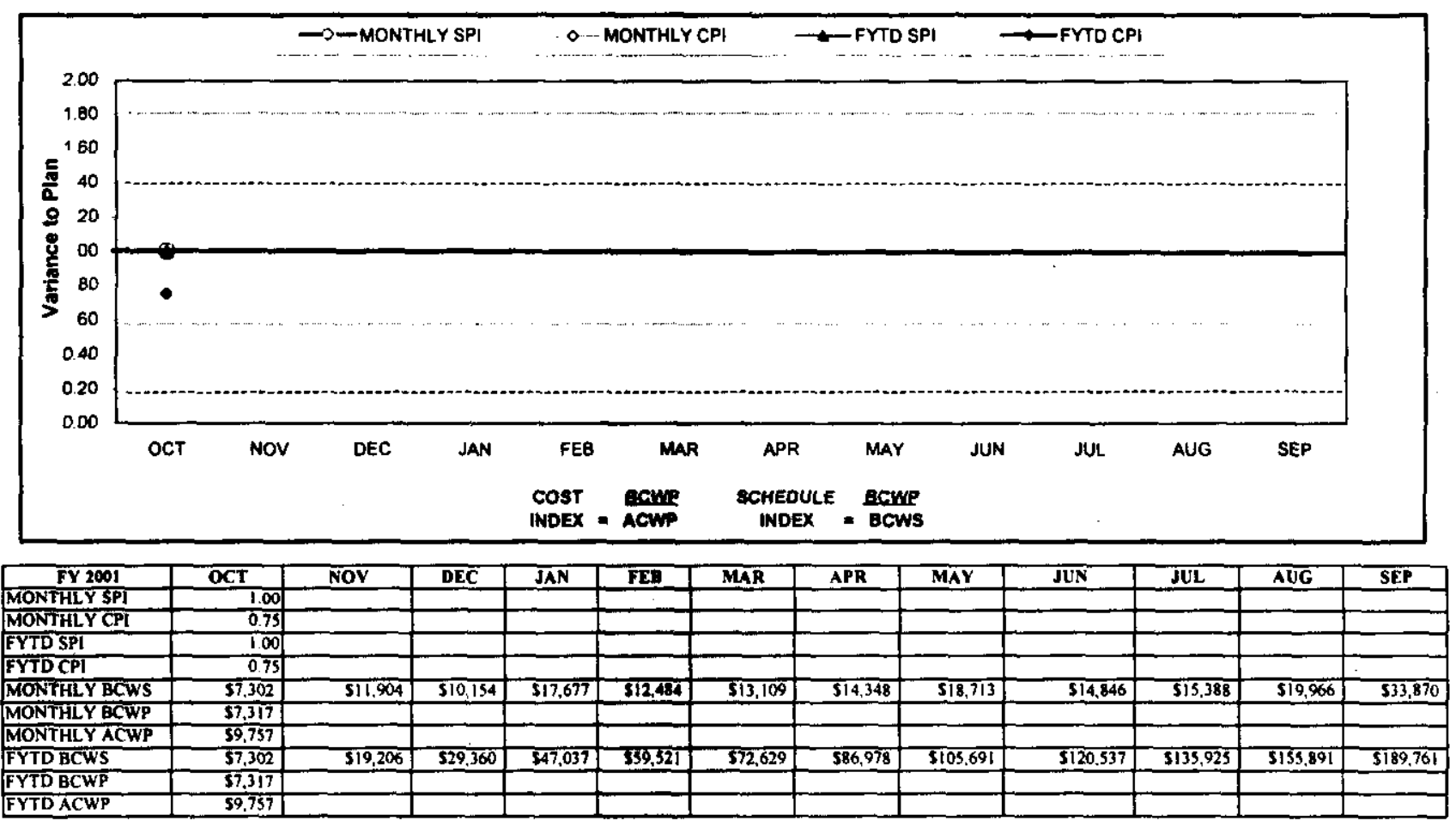

\section{COST VARIANCE ANALYSIS: $(-\$ 2.4 \mathrm{M})$}

\section{WBS/PBS}

\subsection{1/WM01}

Description/Cause: The unfavorable cost variance is due to additional startup and engineering required to resolve first-of-a-king equipment issues at $\mathrm{K}$ Basins and Canister Vacuum Drying (CVD) facility and subsequent extension of the Operational Readiness Review (ORR) process. Impact: Variance impact requires corrective action below. 
PHMC Environmental Management Performance Report - December 2000 T.

Section D-Spent Nuclear Fuel

Corrective Action: A staff demobilization plan has been developed, which will get costs in line with the baseline. The demobilization plan will be initiated following facility startup.

\section{SCHedule Variance ANalysis: (\$0.0M)}

WBS/PBS

1.3.1/ WM01

Description /Cause: None.

Impact: None.

Corrective Action: None.

\section{Title}

Spent Nuclear Fuel Project

\section{Technical Issues}

\section{ISSUES}

There is nothing to report at this time.

\section{DOE/Regulator/External Issues}

- During the Canister Storage Building (CSB) readiness review it was determined that there are American Society of Mechanical Engineers (ASME) N509 and ASME N510 compliance problems with the main ventilation exhaust system.

- A code assessment has been completed to define the scope of the non-compliance.

- Preliminary meetings with Washington Department of Health (WDOH) have taken place and will continue as a path forward is developed.

- A revision to the Notice of Construction has been requested from WDOH, which implements waiver to certain code requirements.

\section{Baseline Change Requests Currently in Process}

(\$000)

Green

\begin{tabular}{|c|c|c|c|c|c|c|c|c|}
\hline $\begin{array}{l}\text { PROJECT } \\
\text { CHANGE } \\
\text { NUMBER }\end{array}$ & $\begin{array}{l}\text { DATE } \\
\text { ORIGIN. }\end{array}$ & BCR TITLE & $\begin{array}{c}\text { COST } \\
\text { IMPACT } \$ 000\end{array}$ & \begin{tabular}{l|l} 
& \\
s & \\
$c$ & \\
H & r
\end{tabular} & \begin{tabular}{|c|} 
\\
DATE \\
TO CCB \\
\end{tabular} & $\begin{array}{l}\text { CCB } \\
\text { APR'VD }\end{array}$ & $\begin{array}{c}\text { RL } \\
\text { APR'VD }\end{array}$ & $\begin{array}{l}\text { CURRENT } \\
\text { STATUS }\end{array}$ \\
\hline FH-2001-002 & $9 / 25 / 00$ & FY2001 Fee Reduction to $90 \%$ & $-\$ 1,030$ & $\mathrm{Y}$ & & & & \\
\hline SNF-2000-001 & $10 / 20 / 00$ & $\begin{array}{l}\text { DOEE Generated ORR Delys to SNF } \\
\text { Critical Path }\end{array}$ & & r) & & & & In Preparation \\
\hline SNF2001-002 & $10 / 26 / 00$ & $\begin{array}{l}\text { MCO Production Rate Changes Based } \\
\text { on Actual Test Results }\end{array}$ & & $Y$ & & & & In Preparation \\
\hline SNF-2001-003 & $11 / 13 / 00$ & SNF Altemate Fuel Transfer Strategy & & $\mathrm{Y}$ & & & & In Preparation \\
\hline SNF-2001-004 & $11 / 14 / 00$ & $\begin{array}{l}\text { Ongoing CSB Operations Revised } \\
\text { Planning Basis ( } \mathrm{CP} 02)\end{array}$ & & $\mathbf{Y} \mid \mathbf{N}$ & & & & In Preparation \\
\hline \multicolumn{9}{|c|}{ ADVANCE WORK AUTHORIZATIONS } \\
\hline & & Nothing to report at this time. & & & & & & \\
\hline
\end{tabular}


Milestone ACHiEVement

\begin{tabular}{|c|c|c|c|c|c|c|c|c|}
\hline \multirow[b]{2}{*}{ MILESTONE TYPE } & \multicolumn{4}{|c|}{ FISCAL YEAR-TO-DATE } & \multicolumn{3}{|c|}{ REMAINING SCHEDULED } & \multirow[b]{2}{*}{$\begin{array}{c}\text { Total } \\
\text { FY } 2001\end{array}$} \\
\hline & $\begin{array}{c}\text { Completed } \\
\text { Early }\end{array}$ & $\begin{array}{l}\text { Completed } \\
\text { On } \\
\text { Schedule }\end{array}$ & $\begin{array}{l}\text { Completed } \\
\text { Late }\end{array}$ & Overdue & $\begin{array}{c}\text { Forecast } \\
\text { Early }\end{array}$ & $\begin{array}{c}\text { Forecast } \\
\text { On } \\
\text { Schedule }\end{array}$ & $\begin{array}{c}\text { Forecast } \\
\text { Late }\end{array}$ & \\
\hline Enforceable Agreement & 0 & o & 0 & 0 & 0 & 0 & 0 & 0 \\
\hline DOE-HQ & 0 & T & 0 & 0 & 0 & 1 & 0 & 1 \\
\hline $\mathbf{R L}$ & 0 & 7 & 0 & 2 & 0 & 2 & 0 & 4 \\
\hline Total Project & $\overline{0}$ & $\overline{0}$ & $\overline{0}$ & $\overline{2}$ & 0 & 3 & $\overline{0}$ & $\overline{5}$ \\
\hline
\end{tabular}

Only TPA/EA milestones and all FY2001 overdue and forecast late milestones are addressed in this report. Milestones overdue are deleted from the Milestone Exception Report once they are completed. The following chart summarizes the FY2001 TPA/EA milestone achievement and a Milestone Exception Report follows. The last milestone table summarizes the first six months of FY2002 TPA/EA milestones.

FY 2001 Tri-Party Agreement / EA Milestones

\begin{tabular}{|l|l|l|}
\hline \multicolumn{1}{|c|}{ Number } & \multicolumn{1}{|c|}{ Milestone Title } & \multicolumn{1}{c|}{ Status } \\
\hline $\begin{array}{l}\text { M-34-16 (S00- } \\
\text { 01-900) }\end{array}$ & $\begin{array}{l}\text { "Initiate Removal of K West Basin Spent } \\
\text { Nuclear Fuel" }\end{array}$ & $\begin{array}{l}\text { Due 11/30/00- One week } \\
\text { behind schedule. }\end{array}$ \\
\hline $\begin{array}{l}\text { M-34-06-T01 } \\
\text { (S04-99-521) }\end{array}$ & $\begin{array}{l}\text { "Initiate K West Basin Spent Nuclear Fuel } \\
\text { Canister Cleaning Operations" }\end{array}$ & $\begin{array}{l}\text { Due 12/31/00 - TPA Change } \\
\text { request in preparation to } \\
\text { extend due date. }\end{array}$ \\
\hline $\begin{array}{l}\text { M-34-05-T01 } \\
\text { (S04-01-515) }\end{array}$ & $\begin{array}{l}\text { "Submit DOE Approved Report Debris to } \\
\text { Ecology/EPA }\end{array}$ & Due 05/31/2001 \\
\hline
\end{tabular}

DNFSB Commitments

$\begin{array}{lll}\text { NumberAWBS Level Milestone Title } & \begin{array}{l}\text { Baseline Forecast } \\ \text { Date }\end{array} & \text { Date }\end{array}$

\section{OVERDue - 2}

$\begin{array}{llll}\text { S03-98-625 RL } & \text { RL Operational Readiness Review (ORR) } & 10 / 13 / 00 & 11 / 30 / 00\end{array}$

\subsection{1}

Report Issued

Cause: Technical issues at Canister Vacuum Drying (CVD) facility delayed Contractor ORR.

Impact: None

Corrective Action: None 


\subsection{1}

\section{Crane Mods)}

Cause: Technical issues at CVD delayed contractor ORR.

Impact: None

Corrective Action: None

\section{FY 2000 OVERDUE - 1}

$\begin{array}{llll}\text { S03-98-602 RL Contractor Operational Readiness Review } & 09 / 07 / 00 \quad 11 / 24 / 00\end{array}$

\subsection{1}

Cause: Unforeseen delays in construction and testing brought on from technical issues within the facilities.

Impact: This milestone was completed November 24, 2000.

Corrective Action: None

FY 2002 Tri-Party Agreement / EA Milestones

\begin{tabular}{|l|l|c|}
\hline \multicolumn{1}{|c|}{ Number } & \multicolumn{1}{|c|}{ Milestone Title } & \multicolumn{1}{c|}{ Status } \\
\hline $\begin{array}{l}\text { M-34-12 (S04-97- } \\
\text { 621) }\end{array}$ & $\begin{array}{l}\text { "Complete Construction of KE Basin Integrated } \\
\text { Water Treatment System (IWTS)" }\end{array}$ & Due 03/31/2002 \\
\hline $\begin{array}{l}\text { M-34-13B-T01 } \\
\text { (S04-98-356) }\end{array}$ & $\begin{array}{l}\text { "Complete Construction \& Installation of KE } \\
\text { Basin FRS" }\end{array}$ & Due 03/31/2002 \\
\hline $\begin{array}{l}\text { M-34-14B-T01 } \\
\text { (S06-97-012) }\end{array}$ & "Complete KE Basin Cask Facility Mods" & Due 02/28/2002 \\
\hline
\end{tabular}

DNFSB Commitments

Nothing to report at this time.

\section{Performance Objectives}

Initiate Fuel Removal (RC-1-1.1a) - First MCO of SNF is moved from KW Basin and transported to the CVD for processing by December 7, 2000 .

- Currently ahead of schedule to move the first MCO by December 7, 2000.

Amount of Fuel Removed for $\mathrm{K}$ Basins and is in Transport, in CVD or at the CSB (RC-1-1.1b) - Total amount of SNF that has been moved from KW Basin and is in transport, in CVD or at the CSB by September 30, 2001 accumulates to $51 \mathrm{MCOs} / \sim 268$ Metric Ton of Heavy Metal (MTHM). 
- A BCR will be submitted by December 31, 2000 to modify FY 2001 expectation to better align with operational experience and actual test results.

Complete KE IWTS Definitive Design - (RC-1-2) - Satisfactorily complete KE IWTS definitive design that factored in the lessons learned from KW IWTS design/construction issues by May 18, 2001.

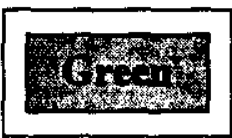

- Currently on schedule to meet May 18, 2001 date.

\section{KEY INTEGRATION ACTIVITIES}

Spent Nuclear Fuel (SNF) final disposition interface activities, including Office of Civilian Radioactive Waste Management (OCRWM) Quality Assurance (QA) Program implementation, are ongoing with the National SNF Program. The SNF Project participated in a National SNF Program strategy meeting that resulted in commitments for resolution of issues related to OCRWM data qualification requirements, licensing strategy for RL-owned SNF inventories, and analyses for evaluating acceptability of N Reactor fuel receipt at Yucca Mountain.

The SNF Project and Waste Management Project continued preparations for K Basins' sludge removal and Shippingport (PA) Pressurized Water Reactor Core 2 SNF removal.

The River Corridor Project and the SNF Project interfaced on contracting strategies and records management for 324 Building (B Cell) SNF removal.

Neutron Radiography Facility Training Research and Isotope Production General Atomics (TRIGA) and Fast Flux Test Facility (FFTF) SNF relocation planning is ongoing with the FFTF Project.

Bechtel Hanford, Inc. transmitted a revised transfer plan for SNF discovered during upcoming $105 \mathrm{~F}$ and $105 \mathrm{H}$ reactor basins deactivation for SNF Project review and approval. This transfer plan incorporated earlier SNF Project comments. 


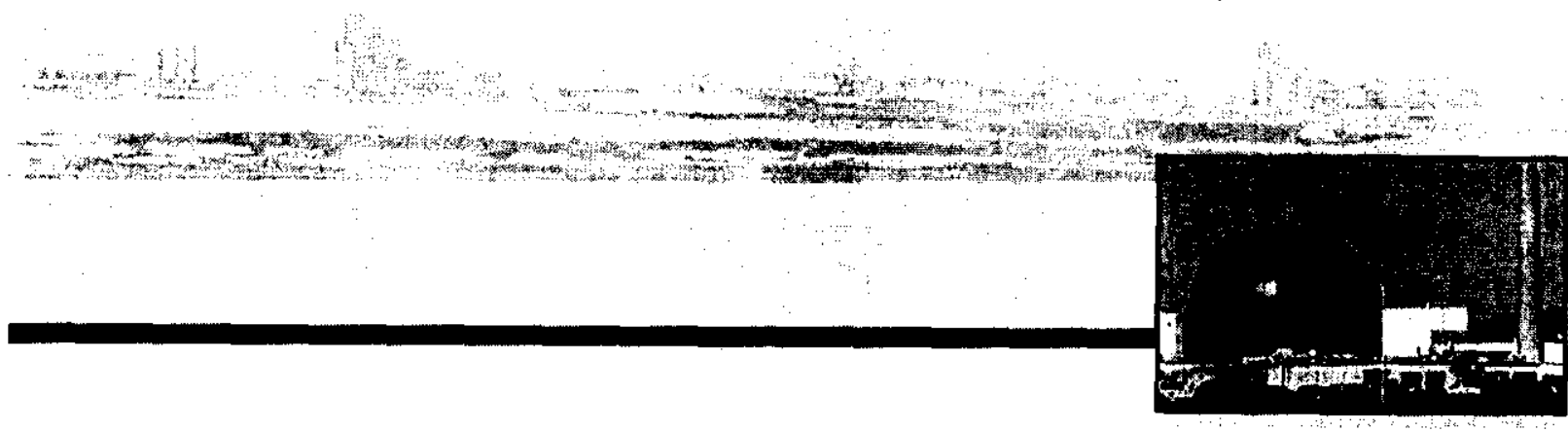

\section{Section E Advanced Reactors Transition}

PROJECT MANAGERS

O.A. Farabee, $\mathrm{RL}$ (509) 376-8089

D.B. Klos, FH (509) 373-3574 


\section{SUMMARY}

The Advanced Reactors Transition (ART) Program, WBS 1.12.1.1, PBS RL-TP11, consists of the 309 Building and the Nuclear Energy (NE) Legacies activities.

NOTE: Cost/Schedule data contained herein is as of October 31, 2000. All information is as of November 17, 2000, unless otherwise noted.

For the month of October surveillance and maintenance activities continued on the 309 Building and NE legacies. The staging of materials continues in anticipation of starting the Fuel Transfer Pit Cleanout work. The work document was submitted for approval. The last of the rinse solutions from the sodium potassium $(\mathrm{NaK})$ alloy residue removal operation were shipped to the Treated Effluent Disposal Facility (TEDF). Statements of work/contract releases were prepared for Fluor Federal Services and Waste Management/Duratek for preparation and shipment of Thermal Transient Loop cold trap to offsite treatment center. Procedures were prepared for inspection of fire doors, barriers, and dampers in the 337B High Bay. Building drawings were updated to show their location.

Fiscal-year-to-date milestone performance (EA, DOE-HQ, and RL) shows that there are no milestones due.

\section{ACCOMPLISHMENTS}

- For the month of October surveillance and maintenance activities continued on the 309 Building and Nuclear Energy (NE) legacies.

- Staging materials continued in anticipation of starting the Fuel Transfer Pit Cleanout work. The work document was submitted for approval.

- Shipped the last of the rinse solutions from the $\mathrm{NaK}$ residue removal operation to TEDF.

- Prepared statements of work/contract releases to Fluor Federal Services and Waste Management/Duratek for preparation and shipment of Thermal Transient Loop cold trap to offsite treatment center.

- Prepared procedures for inspection of fire doors, barriers, and dampers in the 337B High Bay.

\section{SAFETY}

Safety data for ART is included in a separate Fast Flux Test Facility (FFTF) report. 


\section{CONDUCT OF OPERATIONS / ISMS STATUS CONDUCT OF OPERATIONS}

Conduct of operations data for ART is included in a separate FFTF report.

\section{ISMS STATUS}

The project continues to work on improvement initiatives that resulted from the ISMS Phase II readiness review. These initiatives include improving the Automated Job Hazard Analysis (AJHA) process and worker involvement in work documentation preparation.

\section{BREAKTHROUGHS / OPPORTUNITIES FOR IMPROVEMENT}

No breakthroughs or opportunities for improvement have been identified at this time.

\section{UPCOMING ACTIVITIES}

- Ship Thermal Transient Loop cold trap offsite, by March 30, 2001. The date is dependent on receiving a Department of Transportation exemption on the shipping container.

- Continue Fuel Transfer Pit cleanout in the 309 Building/PRTR facility, the estimated completion date is January 30, 2001.

\section{Cost Performance (\$M):}

\begin{tabular}{|l|c|c|c|}
\hline & BCWP & ACWP & VARIANCE \\
\hline Advanced Reactors Transition & $\$ 0.1$ & $\$ 0.2$ & $(\$ 0.1)$ \\
\hline
\end{tabular}

The unfavorable cost variance is due to fiscal year start-up anomalies involving fee accruals and reversals. The ACWP is overstated by $\$ 152 \mathrm{~K}$ and a cost transfer was submitted to correct the cost in this project.

\section{SChedule Performance ( $\$ M)$ :}

\begin{tabular}{|l|c|c|c|}
\hline & BCWP & BCWS & VARIANCE \\
\hline Advanced Reactors Transition & $\$ 0.1$ & $\$ 0.1$ & $\$ 0.0$ \\
\hline
\end{tabular}

There is no schedule variance. 
PHMC Environmental Management Performance Report-December thow

Section E-Advanced Reactors Transition (ART)

\section{FY 2001 Cost/Schedule Performance - All Fund Types Cumulative to Date Status - $(\$ 000)$}

\begin{tabular}{|c|c|c|c|c|c|c|c|c|c|c|c|c|c|c|}
\hline & & \multicolumn{12}{|c|}{ FrTD } & \multirow[b]{2}{*}{ PEM } \\
\hline \multicolumn{2}{|c|}{ By PBS } & \multicolumn{2}{|c|}{ BCWs } & \multicolumn{2}{|c|}{ BCWP } & \multicolumn{2}{|c|}{ ACWP } & \multicolumn{2}{|c|}{ sV } & $\%$ & \multicolumn{2}{|c|}{ CV } & $\%$ & \\
\hline \multirow{2}{*}{$\begin{array}{l}\text { PBS TP11 } \\
\text { WBS } 1.12\end{array}$} & $\begin{array}{l}\text { Advanced } \\
\text { Reactors } \\
\text { Transition }\end{array}$ & $\$$ & 123 & $\$$ & 123 & $\$$ & 183 & $\$$ & 0 & $0 \%$ & $\$$ & $(60)$ & $-49 \%$ & 1,622 \\
\hline & Total & $\$$ & 123 & $\$$ & 123 & $\$$ & 183 & $\$$ & 0 & $0 \%$ & $\$$ & $(60)$ & $-49 \%$ & 16 \\
\hline
\end{tabular}

Note: The Performance Execution Module (PEM) includes $\$ 240 \mathrm{~K}$ for FFTF Inventory support which will be transferred out of PBS RL-TP11 to FFTF.

\section{Cost/SChedule Performance Indices (MONTHLY AND FYTD)}

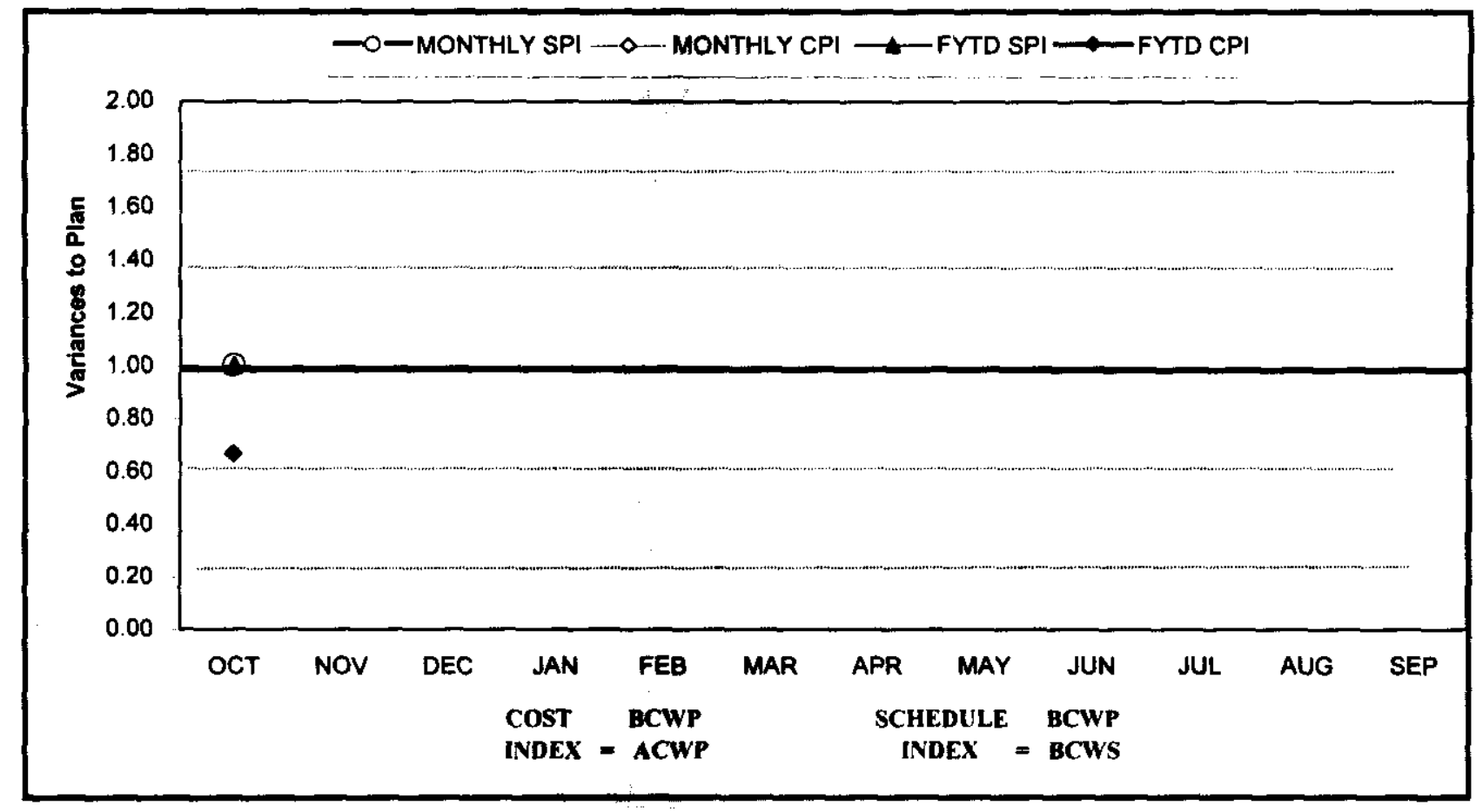

\begin{tabular}{|c|c|c|c|c|c|c|c|c|c|c|c|c|}
\hline FY 2001 & OCT & NOV & DEC & JAN & FEB & MAR & APR & $\mathbf{M A Y}$ & JIIN & JUL & AŨG & SEP \\
\hline MONTHLY SPI & 1.00 & & & & & & & & & & & \\
\hline MONTHLY CPI & 0.67 & & & & & & & & & & & \\
\hline FYTD SPI & 1.00 & & & & & & & & & & & \\
\hline FYTD CPI & 0.67 & & & & & & & & & & & \\
\hline MONTHLY BCWS & 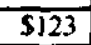 & $\$ 199$ & $\$ 175$ & $5 \longdiv { 4 5 }$ & $\$ 120$ & $\$ 122$ & $\$ 122$ & $\$ 138$ & $\$ 105$ & $\$ 105$ & $\$ 138$ & $\$ 132$ \\
\hline MONTHLY BCWP & $\$ 123$ & & & & & & & & & & & \\
\hline MONTHLY ACWP & $\$ 183$ & & & & & & & & & & & \\
\hline FYTD BCWS & $\$ 123$ & $\$ 321$ & $\$ 497$ & $\$ 642$ & $\$ 762$ & $\$ 883$ & $\$ 1.005$ & $\$ 1,143$ & $\$ 1.248$ & $\$ 1,353$ & $\$ 1,490$ & $\$ 1,622$ \\
\hline FYTD BCWP & $\$ 123$ & & & & & & & & & & & \\
\hline FYTD ACWP & $\$ \overline{183}$ & & & & & & & & & & & \\
\hline
\end{tabular}




\section{COST VARIANCe ANALYsis: $(-\$ 0.1 \mathrm{M})$}

\section{WBS/PBS $\quad$ Title}

\subsection{2/TP11 Advanced Reactors Transition}

Description and Cause: The unfavorable cost variance is due to fiscal year start-up anomalies involving fee accruals and reversals.

Impact: The ACWP is overstated by $\$ 152 \mathrm{~K}$.

Corrective Action: A cost transfer was submitted to remedy the situation.

\section{SCHEdUle VARIANCe ANALYsis: (\$0.0M)}

\section{WBS/PBS}

1.12/TP11

Description and Cause: None.

Impact: None.

Corrective Action: None.

\section{ISSUES}

There is nothing to report at this time.

\section{Baseline Change Requests Currently in Process}

\begin{tabular}{|c|c|c|c|c|c|c|c|c|}
\hline $\begin{array}{l}\text { PRONECT } \\
\text { OANGE } \\
\text { NUMRRR } \\
\end{array}$ & $\begin{array}{l}\text { DATE } \\
\text { ORIGN } \\
\end{array}$ & BCR ITILE & $\begin{array}{c}\text { Fo1 COST } \\
\text { IMPACT } \\
\text { S000 } \\
\end{array}$ & \begin{tabular}{|ll}
$\mathbf{S}$ & $\mathbf{E}$ \\
$\mathrm{C}$ & $\mathbf{C}$ \\
$\mathrm{H}$ & $\mathbf{H}$ \\
\end{tabular} & $\begin{array}{c}\text { DATE TO } \\
\text { CCB }\end{array}$ & $\begin{array}{c}\text { COB } \\
\text { APR'VD }\end{array}$ & RL APR'VD & $\begin{array}{l}\text { CURRENT } \\
\text { STATUS }\end{array}$ \\
\hline FH-2001-002 & $9 / 25 / 00$ & $\begin{array}{l}\text { FY2001 Fee Reduction to } \\
90 \%\end{array}$ & $-\$ 2$ & & & & & At DOE-RL \\
\hline \multicolumn{9}{|c|}{ ADVANCE WORK AUTHORZZATIONS } \\
\hline & & $\begin{array}{l}\text { Nothing to report at his } \\
\text { time. }\end{array}$ & & & & & & \\
\hline
\end{tabular}




\section{MILESTONe ACHIEVEMENT}

Only TPA/EA milestones and all FY2001 overdue and forecast late milestones are addressed in this report. Milestones overdue are deleted from the Milestone Exception Report once they are completed. Fiscal-year-to-date milestone performance (EA, DOE-HQ, and RL) shows that there are no milestones due. The following chart summarizes the FY2001 TPA/EA milestone achievement and a Milestone Exception Report follows. The last milestone table summarizes the first six months of FY2002 TPA/EA milestones.

FY 2001 Tri-Party Agreement / EA Milestones

\begin{tabular}{|c|l|c|}
\hline Number & \multicolumn{1}{|c|}{ Milestone Title } & Status \\
\hline & Nothing to report at this time. & \\
\hline
\end{tabular}

DNFSB Commitments

Nothing to report at this time.

MILESTONE EXCEPTION REPORT

\begin{tabular}{|c|c|}
\hline Number NWBS Level & Milestone Title \\
\hline
\end{tabular}

\section{OVerdue - 0}

ForecAST LATE - 0

FY 2002 Tri-Party Agreement / EA Milestones

\begin{tabular}{|l|l|c|}
\hline \multicolumn{1}{|c|}{ Number } & \multicolumn{1}{c|}{ Mtatus } \\
\hline $\begin{array}{l}\text { B69-02-301 } \\
\text { (M-092-11-T01) }\end{array}$ & $\begin{array}{l}\text { Complete Disposition Options for Hanford Site } \\
\text { Radioactive Na }\end{array}$ & Due 03/31/2002 \\
\hline
\end{tabular}

DNFSB Commitments

Nothing to report at this time.

\section{Performance Objectives}

Nothing to report at this time.

\section{KEY INTEGRATION ACTIVITIES}

Nothing to report at this time. 
PHMC Environmental Management Performance Report - December 2000 Section F- EM-50 Science \& Technology Activities
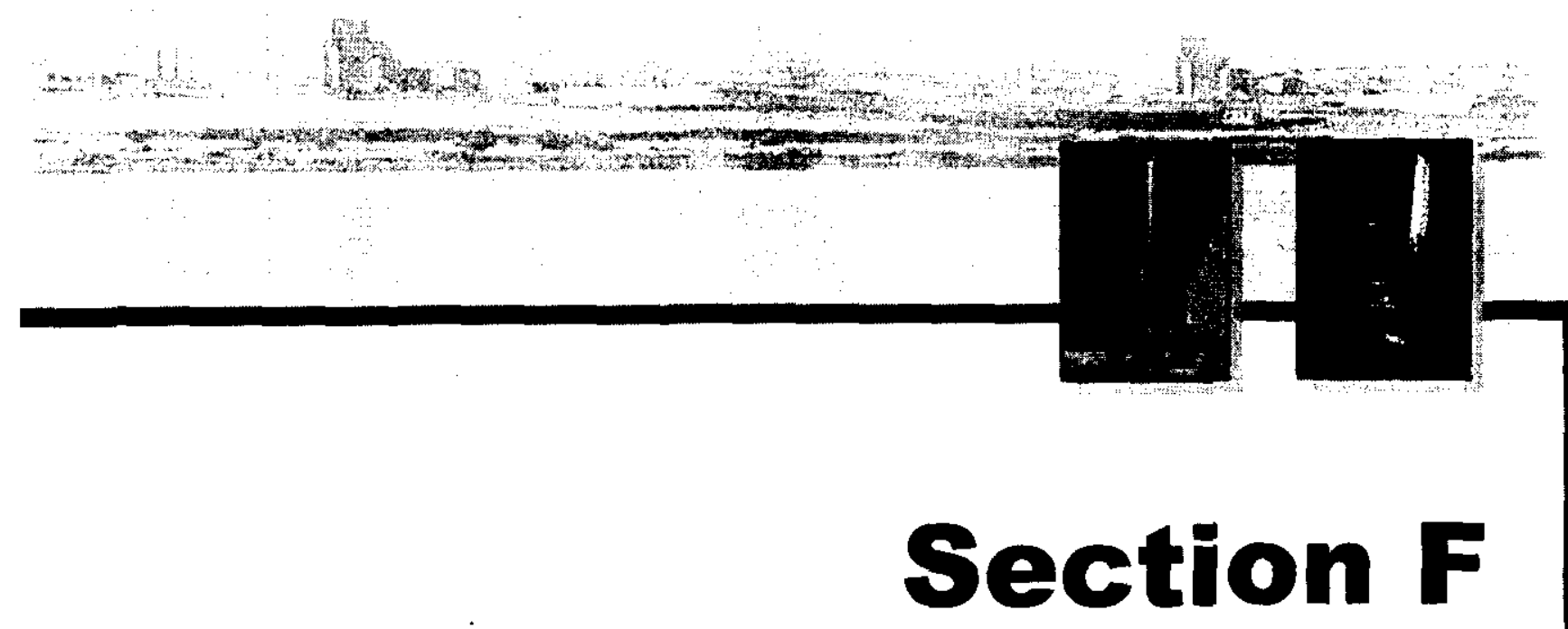

$E M-50$

\section{Science \& Technology Activities}




\section{Milestone ACHIEVEMENT}

\begin{tabular}{|c|c|c|c|c|c|c|c|c|}
\hline \multirow[b]{2}{*}{ MILESTONE TYPE } & \multicolumn{4}{|c|}{ FISCAL YEAR-TO-DATE } & \multicolumn{3}{|c|}{ REMAINING SCHEDULED } & \multirow[b]{2}{*}{$\begin{array}{l}\text { TOTAL } \\
\text { FY } 2001\end{array}$} \\
\hline & Completed Early & $\begin{array}{c}\text { Completed On } \\
\text { Schedule }\end{array}$ & $\begin{array}{l}\text { Completed } \\
\text { Late }\end{array}$ & Overdue & $\begin{array}{c}\text { Forecast } \\
\text { Early }\end{array}$ & $\begin{array}{l}\text { Forecast } \\
\text { On } \\
\text { Schedule }\end{array}$ & $\begin{array}{c}\text { Forecast } \\
\text { Late }\end{array}$ & \\
\hline Enforceable Agreement & 0 & 0 & 0 & 0 & 0 & 0 & 0 & $\overline{0}$ \\
\hline DOE-HQ & 0 & 0 & 0 & 0 & 0 & $T$ & 0 & \\
\hline RL & of & o & 0 & 0 & 우 & $T$ & 0 & \\
\hline Total Project & 0 & 0 & 0 & 0 & 0 & 2 & 0 & $\overline{2}$ \\
\hline
\end{tabular}

\section{MILESTONE EXCEPTION REPORT}

$\begin{array}{lll}\text { Number/WBS Level Milestone Title } & \begin{array}{l}\text { Baseline Forecast } \\ \text { Date }\end{array} & \text { Date }\end{array}$

OVerdue - 0 


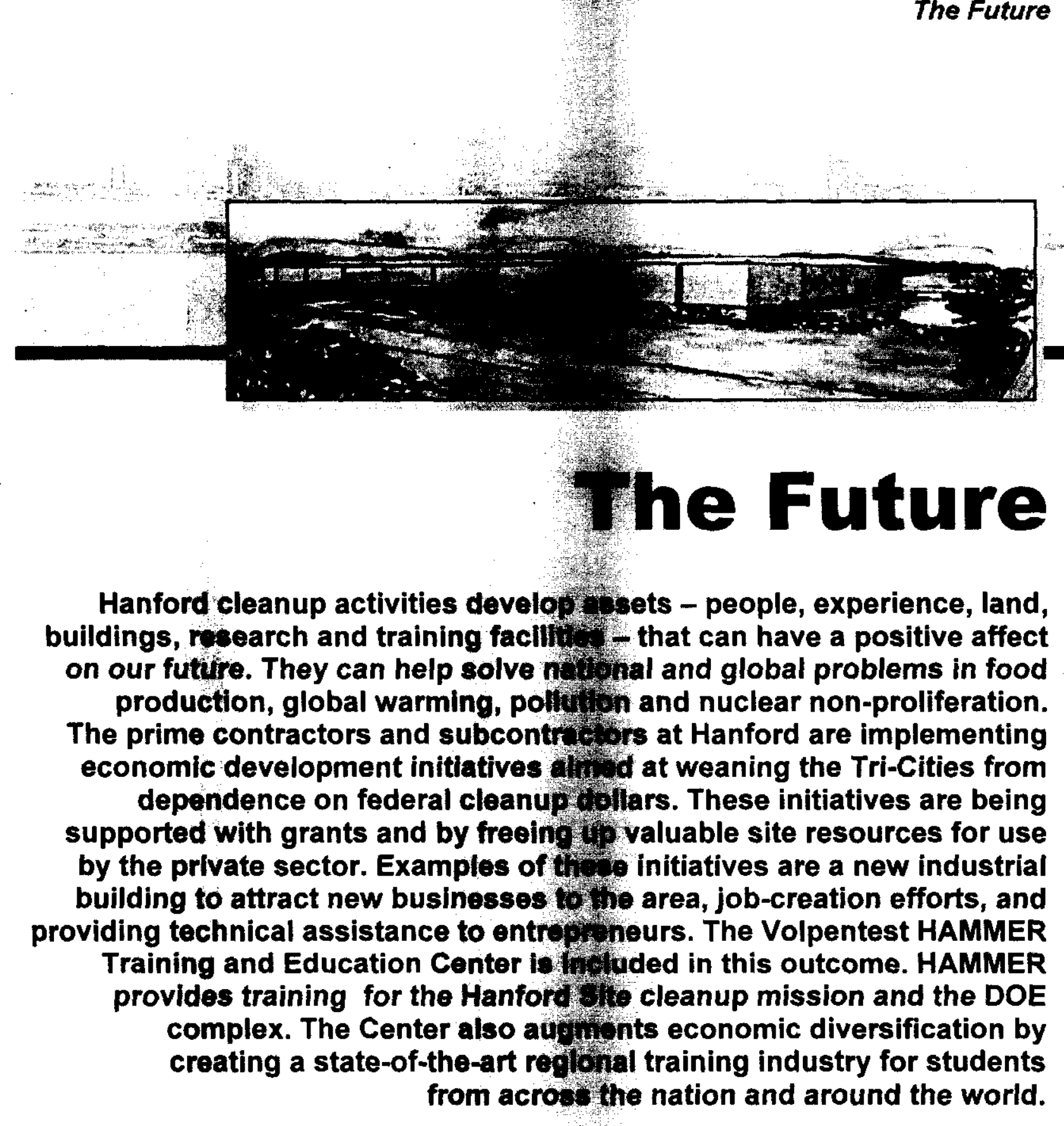

DOE/RL-2000-76, Rev. 0 
PHMC Environmental Management Performance Report - December 2000 Section G - HAMMER

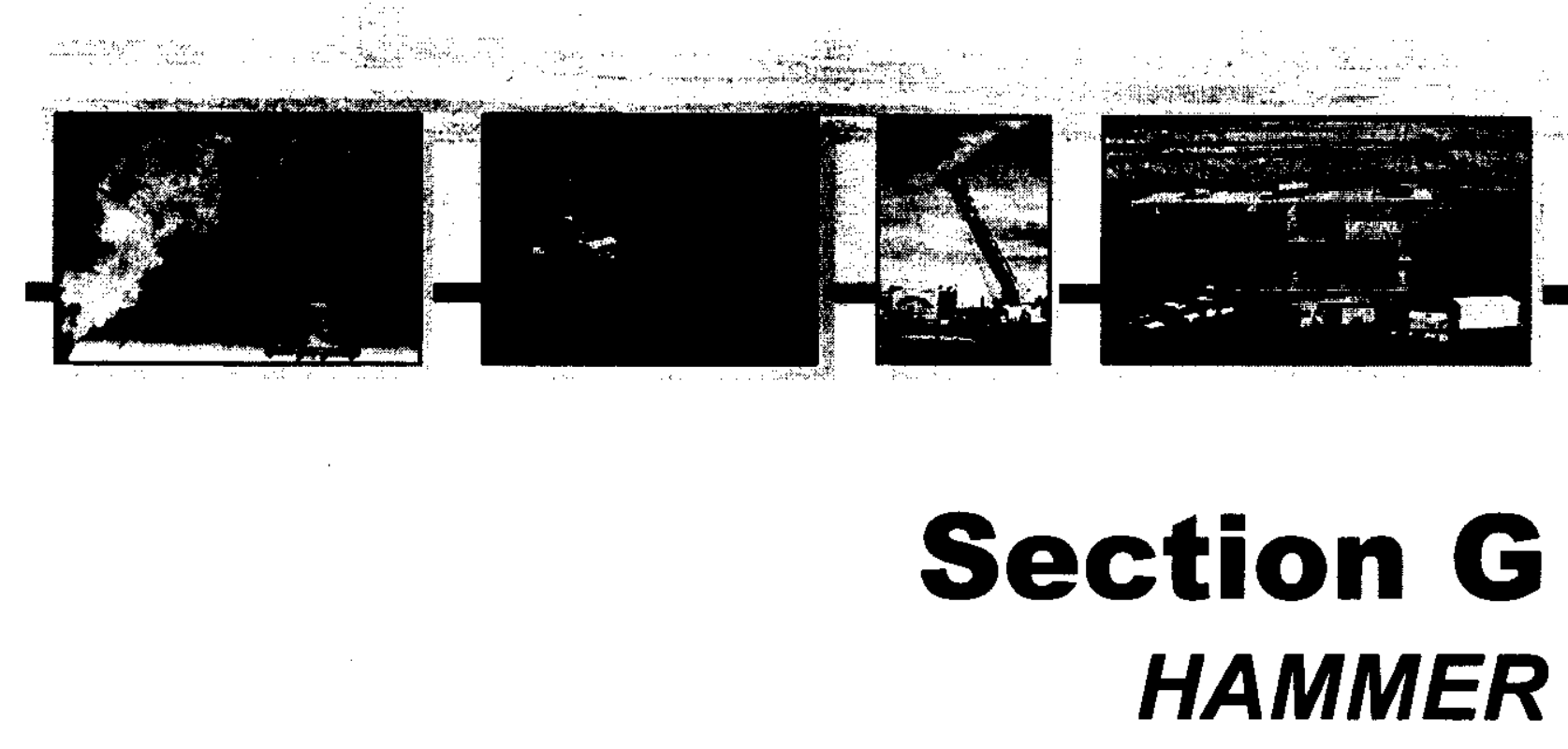

PROJECT MANAGERS

P. W. KRUGER, RL

(509) 372-4005

K.A. McGinnis, FH

(509) 376-9403 
The Hazardous Materials Management and Emergency Response (HAMMER) mission area consists of the HAMMER project, WBS 1.9.1.1, Project Baseline Summary (PBS) HM01.

NOTE: Unless otherwise noted, the Safety, Conduct of Operations, Milestone Achievement, and Cost/Schedule data contained herein is as of October 31, 2000. All other information is as of November 21, 2000.

Volpentest HAMMER's first priority is to deliver hands-on training to the Hanford workforce. During October one hundred fifty-one classes were conducted at the Volpentest HAMMER facility, for a total of 2,278 Hanford site student days. Highest attended health and safety classes included Hazardous Waste Operations, Respiratory Protection, Radiation Worker II Requalification, Tank Farm Operator Continuing Training and Basic Medic First Aid training. Overall satisfaction, rated on a scale from one to five based on level one evaluations, for the month of October: Course Content 4.53, Instructor(s) 4.65, and Facility 4.57.

Pacific Northwest National Laboratory (PNNL) has partnered with HAMMER to use the Waste Tank Prop for acceptance testing and operational training of a robot, which will refurbish the valve pits to be used in the waste vitrification process. The utilization began October 2000 and occurs two weeks of every month through May 2001.

The Board of Directors of the Northwest Public Power Association (NWPPA) has approved the budget and construction plans to develop the 40-acre NWPPA National Utility Training Site located at HAMMER. This prop will meet the hands-on-training needs of workers for the over 200 member organizations of the NWPPA, Hanford site high-risk electrical workers, Occupational Safety and Health Association (OSHA), local and regional fire departments, and law enforcement agencies. Several other training applications for this prop have been recommended and are being pursued.

On October 26-27, 2000, the Archeological Resources Protection Act (ARPA) Incident Investigation class was presented at HAMMER. The organizer of the class was the Confederated Tribe of the Umatilla Indian Reservation. Seventy-nine attendees came from tribal cultural resource and police departments, Federal agencies, police departments throughout the states of Oregon and Washington, coroner office staff members, and prosecutors. The State of Washington's Lead Archeologist and head of the State Historic Preservation Office (SHPO) was also in attendance. The attendees learned about the law pertaining to archeological resources and a better understanding of why these resources are so important. The Cultural Test Bed experience sets this class apart from similar classes and makes it very effective.

Fiscal-year-to-date milestone performance (EA, DOE-HQ and RL) shows that no milestones were due in October and no future milestones are forecast late. 


\section{ACCOMPLISHMENTS}

- Trained 2,278 Hanford site student days at HAMMER.

- Finalized PNNL's utilization of HAMMER's Waste Tank Prop for upcoming training.

- NWPPA approved budget and construction plans to develop the 40-acre NWPPA National Utility Training Site located at HAMMER.

- Conducted ARPA class at HAMMER.

HAMMER currently has no status to report in the areas of ISMS Status, Breakthroughs and Opportunities for Improvement.

\section{UPCOMING ACTIVITIES}

- Perform Hanford Site Limited Exercise, HAMMER, Classrooms \& Waste Tank Prop, November 2000.

\section{Cost Performance (\$M):}

\begin{tabular}{|l|c|c|c|}
\hline & BCWP & ACWP & VARIANCE \\
\hline HAMMER & $\$ 0.0$ & $\$ 0.3$ & $-\$ 0.3$ \\
\hline
\end{tabular}

The unfavorable cost variance of $\$ 0.3 \mathrm{M}$ is due to system problems.

\section{Schedule Performance $(\$ M):$}

\begin{tabular}{|l|c|c|c|}
\hline & BCWP & BCWS & VARIANCE \\
\hline HAMMER & $\$ 0.0$ & $\$ 0.3$ & $-\$ 0.3$ \\
\hline
\end{tabular}

The unfavorable schedule variance of $\$ 0.3 \mathrm{M}$ is due to system problems. 
FY 2001 Cost/Schedule Performance - All Fund Types Cumulative to Date Status - (\$000)

FYTD

Yellow

By PBS

\begin{tabular}{lllllll}
\hline BCWS & BCWP ACWP & SV & $\%$ & CV & $\%$ & PEM
\end{tabular}

PBS HM01

WBS 1.9 .1

Hammer $\$ 332 \quad \$ 27 \quad \$ 281 \quad \$(306)-92 \% \quad \$(254)-957 \% \quad \$ 5,561$

Total

$\begin{array}{lllllllll}\$ 332 & \$ 27 & \$ 281 & \$(306) & -92 \% & \$(254) & -957 \% & \$ 5 & 5,561\end{array}$

\section{Cost/Schedule Performance Indices (MONTHLY AND FYTD)}

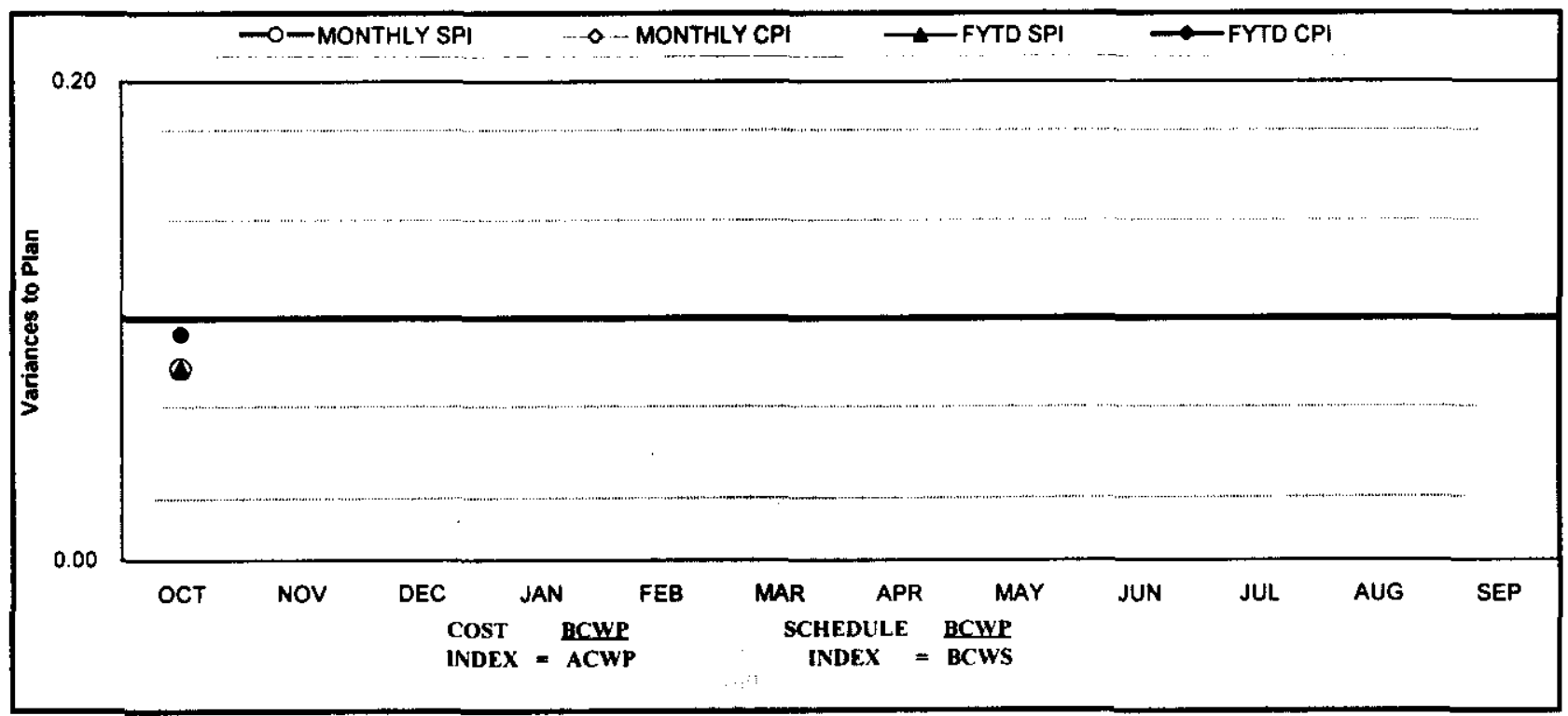

\begin{tabular}{|c|c|c|c|c|c|c|c|c|c|c|c|c|}
\hline FY 2001 & OCT & NOV & DEC & JAN & FEB & MAR & APR & MAY & JUN & JUL & AUG & SEP \\
\hline MONTHLY SPI & 0.08 & & & & & & & & & & & \\
\hline MONTHLY CP1 & 0.09 & & & & & & & & & & & \\
\hline FYTD SPI & 0.08 & & & & & & & & & & & \\
\hline FYTD CPI & 0.09 & & & & & & & & & & & \\
\hline MONTHLY ECWS & $\$ 332$ & $\$ \quad 510$ & 443 & 487 & 421 & 443 & 443 & 554 & 421 & 421 & 554 & 532 \\
\hline MONTHLY BCWP & $5 \quad 27$ & & & & & & & & & & & \\
\hline MONTHLY ACWP & $\$ 281$ & & & & & & & & & & & \\
\hline FYTD BCWS & $\$ 332$ & S 842 & $\$ \quad 1,285$ & S 1.772 & $\$ 2,193$ & $5 \quad 2,636$ & $\$ \quad 3,080$ & $5 \quad 3,633$ & $5 \quad 4.054$ & $\$ \quad 4.475$ & 5.029 & 5.561 \\
\hline FYTD BCWP & $5 \quad 27$ & & & & & & & & & & & \\
\hline FYTD ACWP & $\$ 281$ & & & & & & & & & & & \\
\hline
\end{tabular}




\section{COST VARIANCE ANALYSIS: (-\$0.3M)}

\section{WBS/PBS TITLE}

\subsubsection{1/HM01 HAMMER}

Description and Cause: The variance is due to a system problem, where performance did not properly feed to the scheduling software.

Impact: Minimal.

Corrective Action: The problem will be researched and corrected for November reporting.

\section{SCHEDULE VARIANCE ANALYSIS: (-\$0.3M)}

\section{WBS TITLE}

\subsubsection{1/HMO1 HAMMER}

Description and Cause: The variance is due to a system problem, where performance did not properly feed to the scheduling software.

Impact: Minimal.

Corrective Action: The problem will be researched and corrected for November reporting.

\section{ISSUES}

Nothing to report at this time.

\section{Baseline Change Requests Currently in Process $(\$ 000)$}

\begin{tabular}{|c|c|c|c|c|c|c|c|c|c|}
\hline $\begin{array}{l}\text { PROJECT } \\
\text { CHANGE } \\
\text { NUMBER } \\
\end{array}$ & $\begin{array}{c}\text { DATE } \\
\text { ORIGIN. }\end{array}$ & ACRTUTLE & $\underset{\substack{\text { IMPACT } \\
\text { SOAR }}}{\text { COST }}$ & $\begin{array}{l}\mathbf{s} \\
\mathbf{c} \\
\mathrm{H}\end{array}$ & $\begin{array}{l}T \\
\mathbf{E} \\
\mathbf{C} \\
\mathbf{H}\end{array}$ & $\begin{array}{c}\text { DATE } \\
\text { TOCCB } \\
\end{array}$ & $\begin{array}{c}\text { CCB } \\
\text { APR'YD }\end{array}$ & $\begin{array}{c}\text { RL } \\
\text { ARR'VD }\end{array}$ & $\begin{array}{c}\text { CURRENT } \\
\text { STATUS }\end{array}$ \\
\hline HMR-2000-003 & $7 / 26 / 00$ & FY-2001 MYWP Bridge Change Reuest & 0 & $\mathrm{x}$ & $\mathrm{x}$ & $8 / 25 / 00$ & & $11 / 2 / 00$ & Approved \\
\hline \multicolumn{10}{|c|}{ ADVANCED WORK AUTHORIZATION } \\
\hline & & Nothing to report at this time. & & & & & & & \\
\hline
\end{tabular}


PHMC Environmental Management Performance Report - December 2000

Section $G$ - HAMMER

\section{MILESTONE ACHIEVEMENT}

\begin{tabular}{|c|c|c|c|c|c|c|c|c|}
\hline \multirow[b]{2}{*}{ MILESTONE TYPE } & \multicolumn{4}{|c|}{ FISCAL YEAR-TO-DATE } & \multicolumn{3}{|c|}{ REMAINING SCHEDULED } & \multirow[b]{2}{*}{$\begin{array}{l}\text { TOTAL } \\
\text { FY } 2001\end{array}$} \\
\hline & $\begin{array}{c}\text { Completed } \\
\text { Early }\end{array}$ & $\begin{array}{l}\text { Completed } \\
\text { On Schedule }\end{array}$ & $\begin{array}{c}\text { Completed } \\
\text { Late }\end{array}$ & Overdue & $\begin{array}{c}\text { Forecast } \\
\text { Early }\end{array}$ & $\begin{array}{c}\text { Forecast On } \\
\text { Schedule }\end{array}$ & $\begin{array}{c}\text { Forecast } \\
\text { Late }\end{array}$ & \\
\hline Enforceable Agreement & 0 & 0 & 0 & $\overline{0}$ & 0 & -0 & 0 & 0 \\
\hline DOE-HQ & of & 0 & 0 & 0 & $\bar{c}$ & 0 & 0 & $\overline{0}$ \\
\hline $\mathbf{R L}$ & of & 0 & 0 & 0 & 0 & 9 & 0 & 9 \\
\hline Total Project & of & 0 & 0 & 0 & 0 & 9 & 0 & 9 \\
\hline
\end{tabular}

\section{Green}

\section{Tri-Party Agreement / EA Milestones}

Nothing to report at this time.

DNFSB Commitments

Nothing to report at this time.

\section{MILESTONE EXCEPTION REPORT}

Number/WBS Level Milestone Title

Baseline

Forecast

Date

Date

\section{OVerdue - 0}

Forecast LATE - 0 
PHMC Environmental Management PH, owance Report - December 2000

Multiple Outcomes
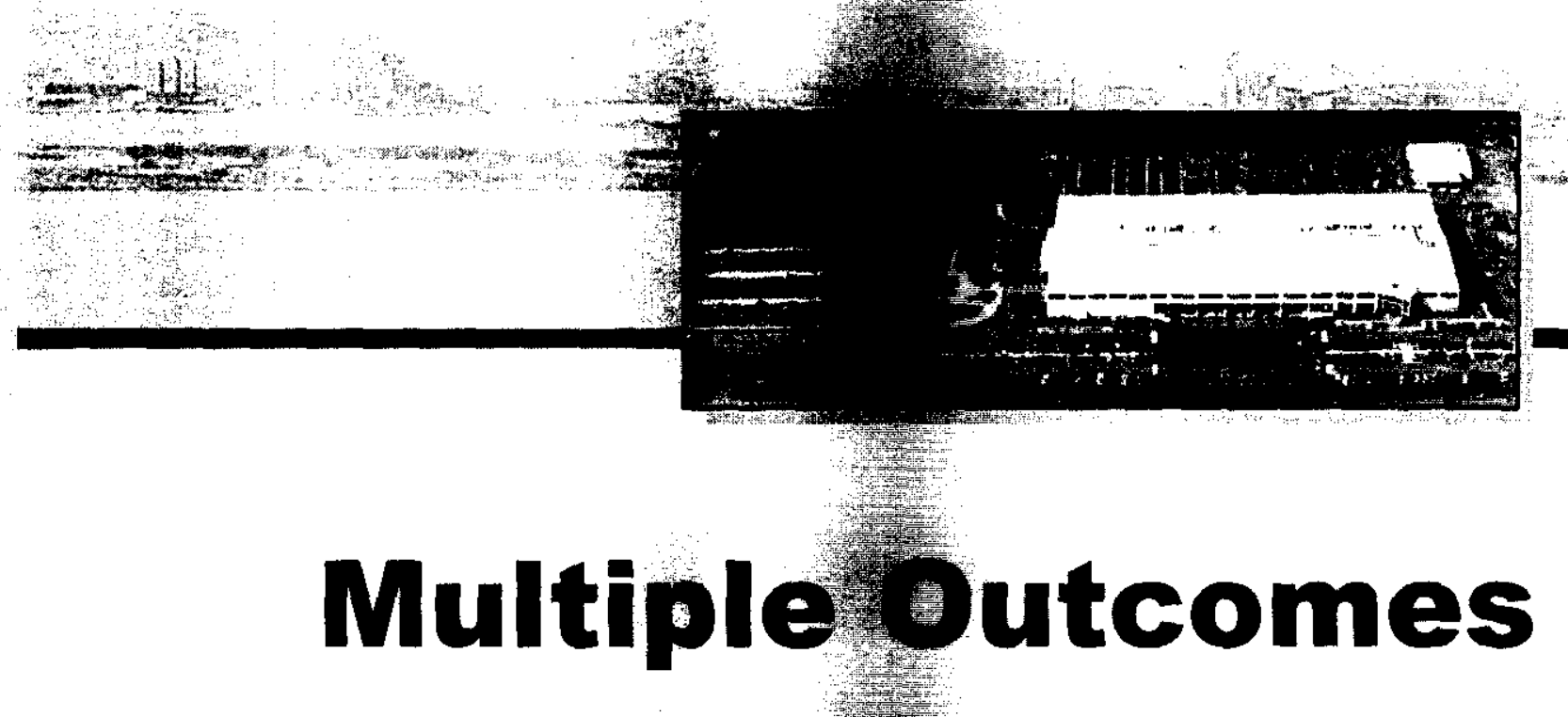

Projects that bridge more than ore outcome are included here. These projects include Landlord, st port, and National Programs. Further descriptions are included in each section. 
PHMC Environmental Management Performance Report - December 2000 Section $\mathrm{H}$ - Landlord

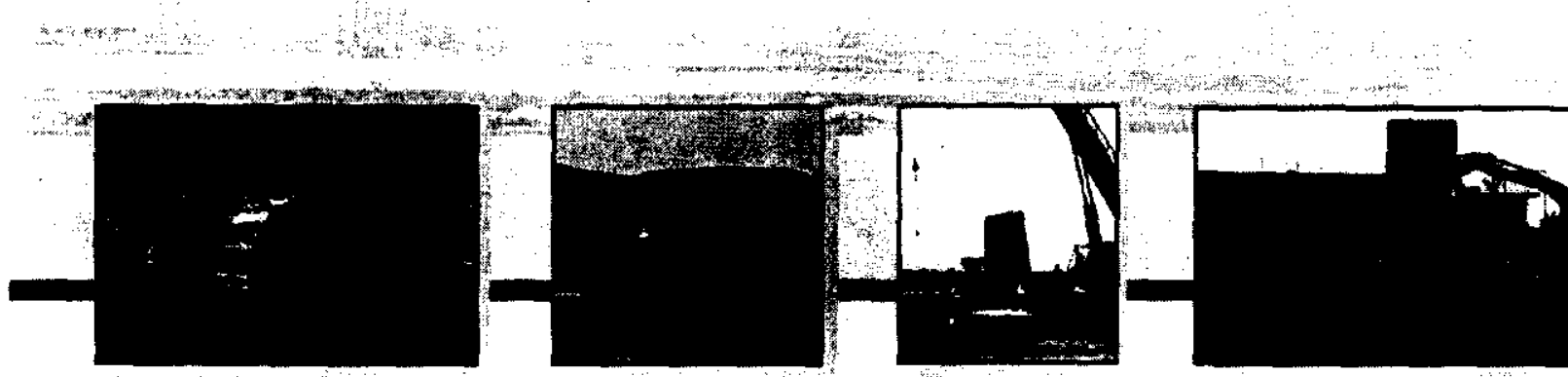

\section{Section H Landlord}

PROJECT MANAGERS S.H. Wisness, RL (509) 373-9337

D.S. Kelly, FH (509) 376-7334 


\section{SUMMARY}

The Landlord mission area consists of the Landlord Project, WBS 1.5.1, Project Baseline Summary (PBS) RL-TP13.

NOTE: Unless otherwise noted, the Safety, Conduct of Operations, Milestone Achievement, and Cost/Schedule data contained herein is as of October 31,2000. All other information is as of November 17, 2000.

Scope for Project L-298, "FY 2000 Road Refurbishments," was carried over to the first quarter of FY 2001 per BCR LPM-2000-009. The reconstruction of the Railroad (RR) Crossing on Rt. 4S, and the overlay of Rt. 1 and K Avenue completed on November 10, 2000. The overlay of an additional 825 feet of rough roadway on Rt. $4 \mathrm{~S}$ south of the RR Crossing has been delayed due to weather conditions. This additional overlay work will be completed as soon as temperatures during the day exceed 40 degrees Fahrenheit.

Landlord Milestone LLC-00-205, "Receive Ambulance by January 29, 2001," is expected to complete in mid-December 2000 , six weeks ahead of schedule, and within budget.

Project L-303, "200 Area Water Chlorine System Modifications," installs a new Chlorine gas bottle containment system in the 200 West Area Water Treatment Plant (WTP). The proposed containment system is a vendor supplied fail safe pressure vessel system that contains leaks from the one-ton Chlorine gas bottle system used for disinfecting the 200 Area Sanitary Water System. The major portion of the vendor-supplied system was received on October 30,2000, but remaining materials and DynCorp Plant Forces availability will delay installation until January 2001. Completion of the installation is expected to complete March 2001.

Fiscal-year-to-date milestone performance (EA, DOE-HQ, and RL) shows no milestones ( 0 percent) are due.

\section{ACCOMPLISHMENTS}

Nine of 11 milestones scheduled for completion this year are trending to complete ahead of schedule and two are expected to complete on schedule.

\section{SAFETY}

Landlord has exceeded one million project safe hours. There was a nearly significant increase in OSHA recordable case rate for April, and a significant increase in DOE Safety Cost Index in April due to reclassification of cases and restricted days accumulated. The months after April 2000 have returned to normal. 
PHMC Environmental Management Performance Report-December 2000 Section $\boldsymbol{H}$-Landlord
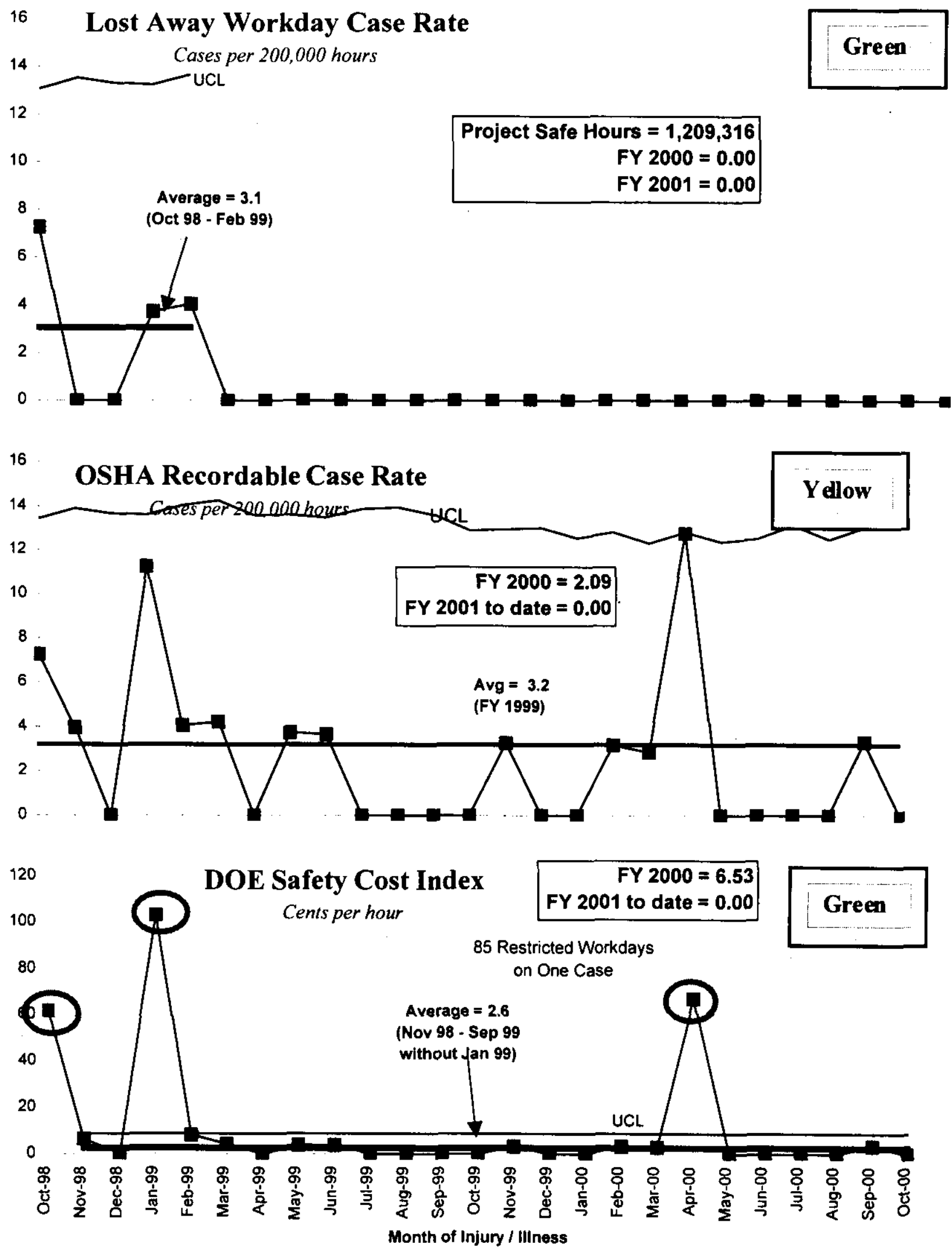


\section{ISMS STATUS}

NOTE: The Infrastructure program includes the Landlord Project and the indirect Infrastructure. Both of these areas are covered under one ISMS program, therefore the ISMS activities described below are for the entire Infrastructure program, which includes Landlord.

- Voluntary Protection Program (VPP) application for status was submitted to DOE and the evaluation was conducted November 14 through November 16, 2000. Initial feedback from the evaluation team was extremely positive. Final results from the evaluation are expected in January 2001.

\section{BREAKTHROUGHS / OPPORTUNITIES FOR IMPROVEMENT}

\section{Breakthroughs}

- Continued activities to complete the proposed FY 2002 conversion of indirect expenses to direct Environmental Management PBS budgeting. This conversion will support the movement of most infrastructure services into RL PBS, TP-13, Landlord Program. With this conversion we will be able to further optimize infrastructure services by integrating normal maintenance and operations with capital improvement projects.

\section{Opportunities for Improvement}

- The Landlord Master Plan displays the development of basis of estimates, which will validate the baseline in the MYWP as Phase II planning activities continue.

\section{UPCOMINC ACTIVITIES}

- Closeout Project L-309, "Replace Main Water Lines" by December 22, 2000.

- Complete installation of a chlorine containment system for Project L-303, "200 West Area Chlorine Mitigation" in March 2001.

Initiate work on the following projects:

- Project L-276, "Emergency Services Equipment Bay Renovations," - FY 2001 GPP to expand and renovate the existing 200 Area Fire Station Equipment Bay. 


\section{Cost Performance (\$M):}

\begin{tabular}{|l|c|c|c|}
\hline & BCWP & ACWP & VARIANCE \\
\hline Landlord & $\$ 1.5$ & $-\$ 0.7$ & $\$ 2.2$ \\
\hline
\end{tabular}

The $\$ 2.2 \mathrm{M}$ (148 percent) favorable cost variance is due to an accrual reversal of $\$ 958 \mathrm{~K}$ for the Department of Interior and Department of Fish and Wildlife for the 24 Command Wildland fire. All Fire costs from all contractors including the Department of Interior, BHI, PNNL, and CH2M Hill are consolidated under the Landlord Project, PBS TP-13. Further information at the PBS level can be found in the following Cost Variance Analysis details.

\section{Schedule Performance ( $\$ M)$ :}

\begin{tabular}{|l|c|c|c|}
\hline & BCWP & BCWS & VARIANCE \\
\hline Landlord & $\$ 1.5$ & $\$ 0.9$ & $\$ 0.6$ \\
\hline
\end{tabular}

The $\$ 0.6 \mathrm{M}$ (66 percent) favorable schedule variance is attributed to road refurbishments being completed sooner than planned due to good weather conditions. Further information at the PBS level can be found in the following Schedule Variance Analysis details.

\section{FY 2001 Cost/Schedule Performance - All Fund Types Cumulative to Date Status - $(\$ 000)$}

FYTD

$\begin{array}{llllllllll}\text { By PBS } & \text { BCWS } & \text { BCWP } & \text { ACWP } & \text { SV } & \% & \text { CV } & \% & \text { PEM }\end{array}$

\begin{tabular}{|c|c|c|c|c|c|c|c|c|c|c|c|c|c|c|}
\hline PBS TP13 & Landlord & $\$$ & 894 & $\$$ & 1,484 & $\$$ & (719) & $\$$ & 590 & $66 \% \$$ & 2,202 & $148 \%$ & $\$$ & 19,930 \\
\hline & Total & $\$$ & 894 & $\$$ & 1,484 & $\$$ & (719) & $\$$ & 590 & $66 \%$ & 2,202 & $148 \%$ & $\$$ & 19,930 \\
\hline
\end{tabular}



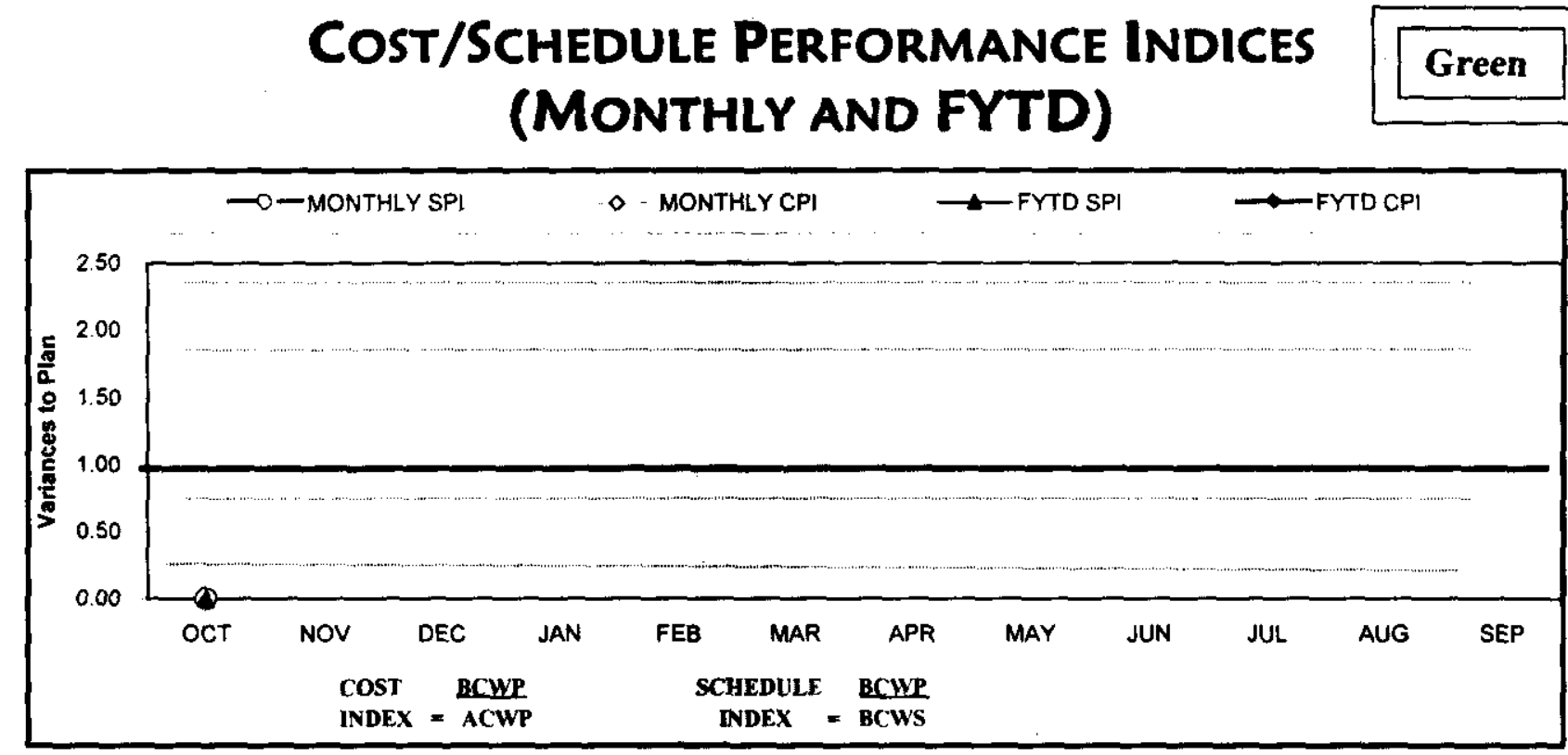

\begin{tabular}{|c|c|c|c|c|c|c|c|c|c|c|c|c|}
\hline FY 2001 & OCT & NOV & DEC & JAN & FEB & MĀR & APR & MAY & JUN & JUL & AUG & SEP \\
\hline MONTHLY SPI & 0.00 & & & & & & & & & & & \\
\hline MONTHLY CPI & -2.06 & & & & & & & & & & & \\
\hline FYTD SPI & 0.00 & & & & & & & & & & & \\
\hline FYTD CPI & -2.06 & & & & & & & & & & & \\
\hline MONTHLY BCWS & $\$ 894$ & $\$ 1.642$ & $\$ 1.676$ & $\$ 1.581$ & $\$ 1,158$ & $\$ 1,217$ & $\$ 1,294$ & $\$ 2,004$ & $\$ 1,491$ & $\$ 1,658$ & $\$ 2,523$ & $\$ 2.791$ \\
\hline MONTHLY BCWP & $\$ 1,484$ & & & & & & & & & & & \\
\hline MONTHLY ACWP & (\$719) & & & & & & & & & & & \\
\hline FYTD BCWS & $\$ 894$ & $\$ 2,536$ & $\$ 4,212$ & $\$ 5,794$ & 56,951 & $\$ 8,168$ & $\$ 9,462$ & $\$ 11.466$ & $\$ 12.957$ & $\$ 14,615$ & $\$ 17.139$ & $\$ 19,930$ \\
\hline FYTD BCWP & $\$ 1,484$ & & & & & & & & & & & \\
\hline FYTD ACWP & (\$719) & & & & & & & & & & & \\
\hline
\end{tabular}

\section{Cost VARIance ANalysis: $(+\$ 2.2 \mathrm{M})$}

\section{$\underline{\text { WBS/PBS }}$}

\subsection{1/TP-13}

Description/Cause: The favorable cost variance is due to an accrual reversal of $\$ 958 \mathrm{~K}$ for the Department of Interior and Department of Fish and Wildlife for the 24 Command Wildland fire. All Fire costs from all contractors including the Department of Interior, BHI, PNNL, and CH2M Hill are consolidated under the Landlord Project, PBS TP-13.

Impact: No impact to overall project and/or final cost.

Corrective Action: The accruals will be corrected in December.

\section{SCHEDULE VARIANCE ANALYSIS: (\$0.6M)}

\section{$\underline{\text { WBS/PBS }} \quad \underline{\text { Title }}$}

\subsection{1/TP13 \\ Landlord}

Description/Cause: The favorable schedule variance is attributed to road refurbishments being completed sooner than planned due to good weather conditions. The Integrated Site Vegetation 
\& Animal Control (ISVAC) Project is also ahead of schedule due to cleanup activities taking less time than planned.

Impact: No impact to overall project and/or final cost.

Corrective Action: None.

\section{ISSUES}

Nothing to report at this time.

\section{Baseline Change Requests Currently in Process $(\$ 000)$}

\begin{tabular}{|c|c|c|c|c|c|c|c|c|c|}
\hline $\begin{array}{c}\text { PROJECT } \\
\text { CHANGE NUMBER } \\
\end{array}$ & $\begin{array}{c}\text { DATE } \\
\text { ORIGIN. } \\
\end{array}$ & BCR TITLE & $\begin{array}{c}\text { COST } \\
\text { IMPACT SO00 } \\
\end{array}$ & $\begin{array}{l}\mathbf{s} \\
\mathbf{C} \\
\mathbf{H}\end{array}$ & $\begin{array}{l}\mathbf{T} \\
\mathbf{E} \\
\mathbf{C} \\
\mathbf{H} \\
\end{array}$ & $\begin{array}{c}\text { DATE TO } \\
\text { CCB }\end{array}$ & $\begin{array}{c}\text { CCB } \\
\text { APR'VD }\end{array}$ & $\begin{array}{c}\text { RL. } \\
\text { APR'VD } \\
\end{array}$ & $\begin{array}{c}\text { CURRENT } \\
\text { STATUS } \\
\end{array}$ \\
\hline FH-2001-002 & $9 / 25 / 00$ & FY2001 Fee Reduction to $90 \%$ & $(\$ 107)$ & & & & & & At DOE-RL \\
\hline \multicolumn{10}{|c|}{ ADVANCE WORK AUTHORIZATIONS } \\
\hline & & Nothing to report at this time. & & & & & & & \\
\hline
\end{tabular}

\section{MILESTONE ACHIEVEMENT}

\begin{tabular}{|c|c|c|c|c|c|c|c|c|}
\hline \multirow[b]{2}{*}{ MILESTONE TYPE } & \multicolumn{2}{|c|}{ FISCAL YEAR-TO-DATE } & \multirow[b]{2}{*}{$\begin{array}{c}\text { Completed } \\
\text { Late }\end{array}$} & \multirow[b]{2}{*}{ Overdue } & \multicolumn{3}{|c|}{ REMAINING SCHEDULED } & \multirow[b]{2}{*}{$\begin{array}{c}\text { TOTAL FY } \\
2001\end{array}$} \\
\hline & $\begin{array}{c}\text { Completed } \\
\text { Early }\end{array}$ & $\begin{array}{l}\text { Completed } \\
\text { On Schedule }\end{array}$ & & & $\begin{array}{c}\text { Forecast } \\
\text { Early }\end{array}$ & $\begin{array}{l}\text { Forecast } \\
\text { On } \\
\text { Schedule }\end{array}$ & $\begin{array}{c}\text { Forecast } \\
\text { Late }\end{array}$ & \\
\hline Enforceable Agreement & $\overline{0}$ & 0 & $\overline{0}$ & $\overline{0}$ & 0 & $\overline{0}$ & 0 & 0 \\
\hline DOE-HQ & 0 & 0 & 0 & 0 & 0 & 0 & of & 0 \\
\hline $\mathbf{R}$ & $\overline{0}$ & $\overline{0}$ & $\overline{0}$ & $\overline{0}$ & 9 & $\overline{2}$ & o & 11 \\
\hline Total Project & $\overline{0}$ & 0 & $\overline{0}$ & 0 & 9 & 2 & o & 11 \\
\hline
\end{tabular}

\section{MILESTONE EXCEPTION REPORT}

Number/NBS Level

Milestone Title

Baseline

Forecast

OVerdue - 0

Date

Date

FORECAST LATE - 0 


\section{Performance Objectives}

The items listed below are not Performance Incentives. They are performance goals (i.e., milestones and goals between $\mathrm{FH}$ and the subcontractor).

\begin{tabular}{|c|c|c|}
\hline Outcome & Performance Goals & Status \\
\hline \multirow{7}{*}{$\begin{array}{l}\text { Restore the River } \\
\text { Corridor for } \\
\text { Multiple Uses } \\
\& \\
\text { Transition the } \\
\text { Central Plateau }\end{array}$} & $\begin{array}{l}\text { Project L-276, "Emergency Services } \\
\text { Equipment Bay Renovation," GPP to } \\
\text { renovate and expand the } 200 \text { Area Fire } \\
\text { Station Equipment Bay Facility (609A) }\end{array}$ & $\begin{array}{l}\text { Currently working on Statement of Work to FFS to } \\
\text { prepare Definitive Design. }\end{array}$ \\
\hline & $\begin{array}{l}\text { Project L-339, "PFP Water System } \\
\text { Isolation- Install Sanitary Water to } \\
\text { WRAP," GPP to install a water bypass line } \\
\text { around PFP to resolve cross contamination } \\
\text { issues with the } 200 \text { West Area potable } \\
\text { water system. }\end{array}$ & $\begin{array}{l}\text { Task Order issued to FFS on November } 13,2000 \text { to } \\
\text { initiate preliminary Definitive Design (DD) } \\
\text { activities. }\end{array}$ \\
\hline & $\begin{array}{l}\text { Project L-340, "Install PFP Backflow } \\
\text { Preventors" Capital Small Project to install } \\
\text { backflow Preventors on the two main } \\
\text { potable water lines to PFP to resolve cross } \\
\text { contamination issues. }\end{array}$ & $\begin{array}{l}\text { Task Order issued to FFS on November } 9,2000 \text { to } \\
\text { initiate preliminary Definitive Design (DD) } \\
\text { activities. }\end{array}$ \\
\hline & $\begin{array}{l}\text { Project L-348, "Fire Damaged 222S Septic } \\
\text { System (2607-W6) Replacement," Expense } \\
\text { Small Project to repair/replace the } 222 \mathrm{~S} \\
\text { Septic System severely damaged by the } \\
\text { June } 2000 \text { fire on the Hanford Site. }\end{array}$ & $\begin{array}{l}\text { FFS was authorized to initiate definitive design for } \\
\text { this project on October } 31,2000 \text { to support } \\
\text { construction completion by June } 30,2001 \text {. }\end{array}$ \\
\hline & $\begin{array}{l}\text { Complete Emergency Services renovation } \\
\text { of the } 200 \text { Area Fire Station. }\end{array}$ & $\begin{array}{l}\text { Construction is continuing with the inside finishing } \\
\text { work on the prefabricated metal building addition. } \\
\text { Overall the project is on schedule }\end{array}$ \\
\hline & $\begin{array}{l}\text { Shutdown approximately } 20 \text { vacant office } \\
\text { facilities and deactivate } 20 \text { vacant facilities. }\end{array}$ & $\begin{array}{l}\text { Approximately } 80 \text { vacant facilities are in the } \\
\text { Surveillance and Maintenance (S\&M) status, two } \\
\text { have been shutdown, and four have been } \\
\text { deactivated. }\end{array}$ \\
\hline & $\begin{array}{l}\text { Capital Equipment replacement purchases } \\
\text { of a Fire Engine Pumper Truck, Electrical } \\
\text { Utilities Truck, and a 33-Ton Crane. }\end{array}$ & $\begin{array}{l}\text { Vendor quote was received on the Fire Engine } \\
\text { Pumper Truck replacement and will be placed with } \\
\text { the vendor by the end of November } 2000 .\end{array}$ \\
\hline $\begin{array}{l}\text { Put Assets to } \\
\text { Work for the } \\
\text { Future }\end{array}$ & $\begin{array}{l}\text { Disposition One Well Car and one Auger } \\
\text { Drill Truck, and S\&M of the } 212 R \text { rail } \\
\text { siding where the majority of the remaining } \\
\text { regulated rail cars are staged for future } \\
\text { disposition. }\end{array}$ & $\begin{array}{l}\text { The initiation of the disposition of the Auger Truck } \\
\text { has been placed on hold pending funding reductions. } \\
\text { The disposition of the Well Car may also be deferred } \\
\text { pending funding reductions. }\end{array}$ \\
\hline
\end{tabular}




\section{KEY INTEGRATION ACTIVITIES}

- Developed a Long Range Infrastructure Plan, which identifies critical infrastructure projects needed to support the Site's mission needs. Planning and integration meetings were held with Site programs to fully understand and integrate their requirements. The information contained in the Long Range Infrastructure Plan was later requested by RL in the form of a Schedule Options Study for Site Infrastructure, and DOE-HQ in the form of an Infrastructure Restoration Plan.

- Supported the Office of Environmental Management (EM) in reviewing infrastructure budget and policy issues as part of the Infrastructure Life Extension Campaign. The effort might result in an addendum to EM's FY 2002 budget request to the Office of Management and Budget. 


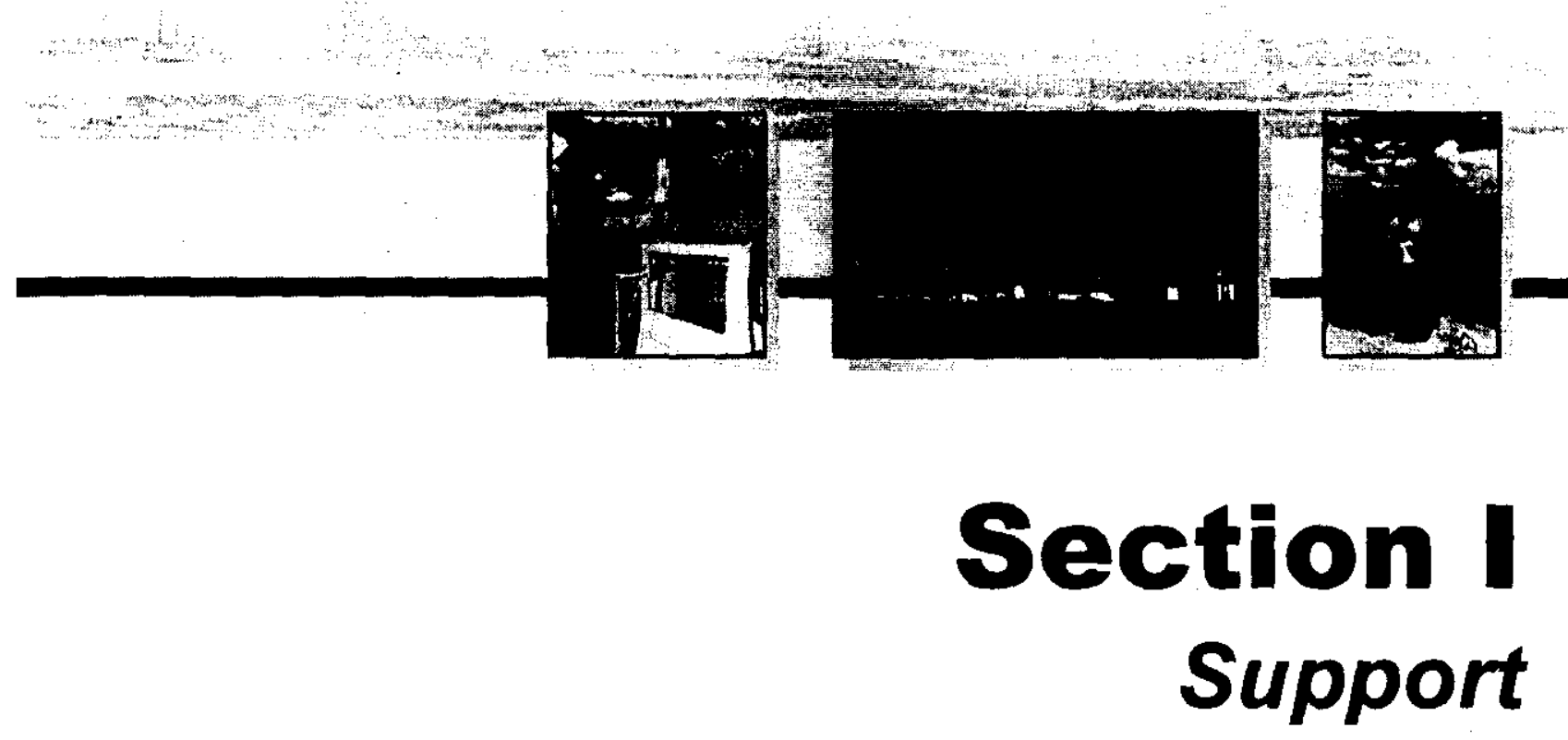

SP\&I W.W. Ballard, RL

PROJECT MANAGERS G.J. McCleary, FH

(509) 376-6657

(509) $372-8385$

SSE W.W. Ballard, RL

M.L. Grygiel, FH

ECP S.H. Wisness, RL

J.W. Hales, FH

PSRP S.H. Wisness, RL

R.L. Dirkes, PNNL
(509) 376-6657

(509) 372-2983

(509) 373-9337

(509) 376-4069

(509) 373-9337

(509) 376-8177 


\section{SUMMARY}

Mission Support, Project Baseline Summary (PBS) OT01, consists of four sub-projects:

- Planning and Integration [Work Breakdown Structure] (WBS 1.8.2.1)]

- Systems Engineering (WBS 1.8.2.2)

- Environmental Compliance (WBS 1.8.2.3)

The Environmental Compliance Program is composed of two elements. These two elements were stand-alone programs known as the Hanford Environmental Management Program (HEMP) and the Effluent and Environmental Monitoring Program (EEM) prior to FY99. Although there is a single program, these elements retain their identity on the Integrated Priority List as two separate Units of Analysis.

- Public Safety and Resource Protection (WBS 1.8.2.4)

NOTE: Unless otherwise noted, the Safety, Conduct of Operations, Milestone Achievement, and Cost/Schedule data contained herein is as of October 31,2000. All other information is as of November 17, 2000 unless otherwise noted.

\section{Project Controls}

Draft FY 2001 Phase II Multi Year Work Plan (MYWP) Delivered - In compliance with the Baseline Update Guidance (BUG) Phase II requirements, draft Fiscal Year (FY) 2002 (through life cycle) Multi-Year Work Plans (MYWPs) were formally transmitted to DOE-RL on November 15, 2000. Consistent with the guidance, the draft Phase II submittal:

- Reflects the conversion of several indirect accounts to direct accounts.

- Realigns project baselines to the Preferred Schedule Option Case (PSOC) work scope.

- Reduces FH Base Operations by ten percent through FY 2016.

- Implements DOE's phased approach to Order 435.1, requiring the identification and incorporation of radioactive waste management activities in life-cycle baselines.

Discussions are underway with the Mission Planning Division to incorporate feedback and resolve issues in preparation for the final submittal, due December 15, 2000.

MYWP Systems Support - New cost baseline exhibits were developed for the Project Execution Reporting Module (PERM) to support the Phase II electronic MYWPs; these exhibits (currently in test phase) allow for formula calculation of escalation and fee amounts over the life cycle of the project.

FY 2001 Safeguards and Security (SAS) WBS - SAS will remain an EM-funded activity in FY 2001. Therefore, Project Controls moved Safeguards and Security from the 2.14 WBS (Work-for-Others structure) to WBS 1.13 in the Environmental Management structure for FY 2001 execution.

FY 2002 RL Work Breakdown Structure - Project Controls is incorporating the FY 
2002 Work Breakdown Structure for DOE-RL per the final MYWP Phase II BUG. This includes some level 3 and many level 4 changes. Level 5 must be determined and incorporated before the Projects can map the existing baseline activities to the new structure.

Site Summary Schedule Update - During October, efforts continued on the development of a revised Site Summary Schedule to reflect significant activities and deliverables aligned to Site Outcomes, and to be an effective communications tool with its stakeholders and regulators. The basic format has been developed and the process of defining the major work activities and milestones is progressing. The latest update divides the schedule graphic into three pages. Page 1 will display the River Corridor, page 2 will display the Central Plateau and page 3 will contain pictures, graphs, tables, etc. The initial product will display all activities relative to achieving significant clean up by 2012. A review cycle will be conducted to remove events deemed unnecessary and add any omissions. Discussions regarding content are ongoing between FH Project Controls, Pacific Northwest National Laboratory (PNNL), and Bechtel Hanford, Inc. (BHI).

RL Summary Schedule (1000 Node) Update - Project Controls is currently updating the RL Summary Schedule to the August 2000 baseline. Updated MYWP schedule exhibits will be displayed in the Hanford Data Integrator (HANDI) system by mid-December. As part of the Phase II MYWP updates, the Projects will re-plan detailed work activities consistent with the PSOC provided in the Phase II BUG. Updated detailed schedules will then form the basis for updated RL Summary Schedule. Project schedulers continue to meet with their representatives on the schedule options team to map existing baselines and/or develop new schedule activities in support of the preferred option. The re-priced detailed project schedules will be used to determine if the preferred schedule option can be supported within funding realities.

Support for RL Integrated Science and Technology (S\&T) Plan - Project Controls is supporting the RL-Assistant Manager for Planning and Integration and RL-Assistant Manager for Science and Technology activities to provide a Site perspective on major challenges impacting the cleanup mission. This is a site wide S\&T planning effort initiated from the DOEHQ/EM-50 (Gerald Boyd) visit to the Hanford Site several weeks ago. A "top-down" approach will be used to develop the Site plan utilizing existing Groundwater/Vadose Zone and Spent Nuclear Fuel S\&T Plans as first steps. A draft of the Site plan is targeted for completion the end of January.

Performance Management Meetings - As requested, the November 1 and 2, 2000, "River" and "Plateau" Performance Management Meetings (PMMs) were arranged to provide an overview of FH's FY 2000 performance. In a departure from the usual monthly status format, the standard topic areas (including accomplishments, safety status, breakthroughs, opportunities for improvement and performance objectives achievement, cost/schedule performance, and issues) reviewed performance for the whole of FY 2000. Pre-meeting materials were distributed to attendees for both meetings as planned, and both meetings were held as scheduled.

Environmental Management Performance Report (EMPR) - The October EMPR was delivered to RL on October 11, 2000, as scheduled. The November EMPR was delivered on Friday, November 10, 2000. This year-end report included summaries of each Project's 
accomplishments for FY 2000, as well as a list of FH's overall "Top Five" accomplishments. To add focus to each accomplishment, they were individually categorized into one of three groups: Momentum, Progress, and Completion \& Removal.

Business Management Oversight Process (BMOP) Status - As required by DOE 224.1 , a self-assessment report addressing the FY 2000 BMOP expectations and measurement criteria was submitted to DOE-RL on October 30, 2000.

The FY 2001 draft BMOP expectations and measurement criteria were transmitted to the FH Points of Contact (POCs) for review and comment in September. Although RL's target date to finalize the FY 2001 Plan was September 30, 2000, the FY 2001 BMOP criteria were not issued until October 31, 2000. Upon review, it was discovered that additional changes were necessary. Consequently, the document will be reissued sometime in December.

Performance Execution and Reporting Module (PERM) Status - September FY 2000 and year-end performance data was collected in the PERM module and batch-fed to the DOE-HQ Integrated Planning and Budgeting System-Project Execution Module (IPABS-PEM) system on November 3,2000. After transmittal to DOE-HQ, the data set was rolled over to accommodate the collection of FY 2001 data. October's FY 2001 performance data is due to DOE-HQ the week of November 24, 2000.

\section{Systems Engineering and Integration (SE\&I)}

FH Systems Engineering and Integration is supporting several RL, FH, and Project level initiatives at this time. The initiatives being supported include the Schedule Options Study and the re-alignment of the Project Baseline Summaries. Other initiatives include the Requirements Initiatives Integration Team and the Phase II Baseline Update Guidance. Project level initiatives include Waste Management Project Strategic Planning, the Spent Nuclear Fuels alternative analysis, and a Value Engineering study for the River Corridor Project.

\section{Environmental Compliance Program (ECP)}

Ecology initiated modification of the Hanford Facility (HF) RCRA Permit, Dangerous Waste (DW) portion in two parts. The two parts consist of the corrective action portion and changes to be incorporated as part of Modification E. Ecology issued the corrective action portion on March 29, 2000, and an appeal was submitted on April 27, 2000. Resolution discussions were held in Seattle on October 31,2000, between Ecology and DOE to discuss the corrective action appeal and the potential appeal of the proposed Modification E issuance. As a result, DOE and Ecology legal counsels are working on revised language for the corrective action portion. Ecology also agreed to evaluate the Waste Analysis Plan (WAP) for WRAP provided in Modification E, and evaluate it against Modification F WAP for 222-S. The results of the WAP evaluation will determine the path forward for issuance of Modification $E$ and Modification F.

The software bridge between the Chemical Management System (CMS) and the P-Card System was successfully tested. The first inventory of chemicals using the CMS by demonstrating 
capability to receive, bar code, inventory and track chemicals at PFP was successfully conducted.

WDOH submitted a letter dated October 18, 2000, which supercedes the March 1, 2000 letter on the Hanford Site Maximally Exposed Individual (MEI). As expected, WDOH has clarified their MEI definition to include any member of the public who is employed on "DOE-owned but unrestricted land." Fortunately, this definition excludes the Columbia River shoreline and WYE barricade scenarios that were in the original letter. WDOH expressed their willingness to work with $\mathrm{RL}$ and Site contractors in establishing the best dose modeling for all release conditions.

\section{Public Safety and Resource Protection (PSRP)}

Public Safety and Resource Protection (PS\&RP) staff is engaged in the RL FY 2001 budget modification scenarios to identify top priority activities and impacts of potential budget reductions. The evaluations include the identification and prioritization of FY 2000 carryover scope, identification and prioritization of "emerging issues," and the identification of potential impacts to be realized if the program receives an eight percent budget reduction from the currently approved baseline.

\section{ACCOMPLISHMENTS}

\section{Project Controls}

- The deliverable, Submit Summary of Proposed Updates for MYWP Phase II was delivered on November 15, 2000 as scheduled.

- The deliverable, Submit Initial FY 2001 MYWP Phase Il Strategic Synopsis was delivered on November 15, 2000 as scheduled.

- The deliverable, Submit FY 2000 BMOP Self Assessment Report was delivered on October $30,2000$.

- The deliverable, Monthly EMPR was delivered on October 11, 2000.

- The deliverable, Deliver Project Execution Module (PEM) FY 2000 Year-End Report to DOE-HQ was completed on November 3, 2000.

\section{Systems Engineering and Integration}

FH Systems Engineering and Integration (SE\&I) supported the accomplishment of the Fluor Hanford Mission in the following areas:

- SE\&I supported the initiative (Requirements Initiatives Integration Team [RIIT]) to find at least $\$ 30 \mathrm{M}$ in efficiencies in base operations to allow RL to fund critical work in FY 2001 and FY 2002. This initiative has currently identified over $\$ 26 \mathrm{M}$ in efficiencies.

- SE\&I is working on the initiative to align the Project Baseline Summaries (PBS) and Work Breakdown Structure (WBS) to the Hanford Outcomes.

- SE\&I is working with Project Controls and the FH Projects to implement the Phase II Baseline Update Guidance.

- SE\&I worked with the FH projects to provide integrated technical information for the IPABS-IS data feed. 
- SE\&I is working with the Spent Nuclear Fuels Project to analyze alternatives to the current baseline. The alternative being analyzed relates to moving fuel from the $\mathrm{K}$ East basin into the $K$ West basin for cleaning and packaging.

- SE\&I is supporting the Waste Management Project Strategic Planning efforts.

\section{Environmental Compliance}

\section{RCRA Permit}

- The Class 1 modifications to the Hanford Facility RCRA Permit for Quarter ending September 30, 2000 for the Internet, was processed. The Hanford Facility Emergency Management Plan, PUREX Storage Tunnels, and LERF/ETF have been posted to the Internet. The 242-A modifications are awaiting revised modification forms to correct errors in the September 30 submittal.

- Milestone ECP-01-705, issue and post on the Internet the Annual Hanford Site Environmental Permitting Status Report, was completed on November 14, 2000. The report contains summaries for over 400 RCRA, Clean Air, and Clean Water Act permits that are currently active.

- Milestone ECP-01-702, Closure/Post closure Cost Estimate was completed on October 23, 2000 . The volume of the routine data used in the report was significantly reduced. The report was delivered to Ecology on October 31, 2000.

- Representatives from RL, FH, and BHI met with Ecology concerning the closure of the area where 17 drums of Multi Media Interface (MMI) disputed waste that were stored in the 200 East Pipe Lay down Area. The start date for compliance with the MMI Consent Agreement Final Order (CAFO) was agreed upon to be October 16, 2000. The first CAFO requirement to meet with Ecology within 30 days was met. Meeting minutes will be issued to document the meeting. Agreement was reached on the general closure plan outline and contents. The final closure

plan will be delivered to Ecology on February 13, 2001 with a public review and comment period.

- A Part B permitting workshop was held with Ecology for the Low-Level Burial Grounds (LLBG). Ecology stated their desire for the LLBG boundaries to remain as in the last approved Part A permit application, including all 8 burial grounds. In addition, Ecology asked that all mixed waste disposed of since the initial Part A, Revision 0, was submitted in 1985 be identified. FH requested more time to discuss the issue before responding.

\section{Air \& Water Program}

- Assistance was provided to T-Plant for the preparation of preliminary information for the radiation air notice of construction. Concurrence from WDOH that preliminary activities supporting fuel removal, such as electrical and lighting upgrades and fuel canister fabrication, can precede was presented at the November Routine Technical Assistance Meeting (RTAM).

- The bimonthly Air/Water Permit Schedule was placed on the Intranet under the Air Operation Permit homepage on November 1, 2000. With the expansion in the number of Hanford prime contractors and DOE offices, this has become an increasingly difficult task. Plans are to build a simple table for the Air Operating Permit Home Page where each 
contractor can periodically update their permitting information. The table should be available for use by all prime contractors and DOE offices by January 2001 .

- The monthly Discharge Monitoring Report for September 2000 was sent to the Director, Office of Water, and EPA Region 10 (with copies to Ecology and RL) under the site-wide NPDES permit.

- The Permittee Data Report was sent to Environmental Resource Associates, an EPA designated vendor, to meet an interim requirement under National Pollutant Discharge Elimination System (NPDES) Discharge Monitoring Report-Quality Assurance Study \# 20 by EPA.

- An update to the Class V Underground Injection Control (UIC) Well registration is in preparation. The UIC listing is required under WAC 173-218.

- The Routine Technical Assistance Meeting with WDOH was coordinated to acquire approval for surveillance of the $231-Z$ building, Notice of Construction (NOC) revision for WSCF, concurrence on pre-construction/routine activities for $T$ Plant, and the removal of the Shipping port Fuel and storage of the K Basin Sludge.

\section{NEPA}

- NEPA coverage was provided for the 218-W-5 LLBG review regarding possible trench addition to $218-\mathrm{W}-5$.

\section{Air Compliance}

- Management and integration support was provided on the asbestos site-wide program in billing verification and tracking asbestos Notification of Intent approvals for the site contractors, including Bechtel Hanford (BHI) and PNNL. Agency interaction involves frequent contact with the Benton Clean Air Authority (BCAA). A call for site wide facility input was also developed/initiated, pursuant to WMP-GD-ES-401, for incorporation into the annual asbestos notification of intent, due to the BCAA in December. This activity will complete an ECP milestone.

- Coordination support will be provided during the first fiscal quarter of 2001 for the planned Ecology Air technical assistance visits. An Ecology Air Interface meeting was also held the first week of November. Participants from FH, RL, BHI, and PNNL discussed current issues with the Ecology permit writer/Point of Contact (POC) in this forum.

- A review was conducted of the BHI strategy for air permitting of planned entry/sampling of hexone tanks (276-S-141/142 tanks). WDOH and EPA provided assistance regarding options for developing documentation for rapid approval. This work was conducted in support of the site wide aspect of clean air compliance associated with accessing waste tanks for sampling/characterization.

- Continued as the Point-of-Contact for FH with the WDOH Olympia and Richland offices, regarding the Washington State Radioactive Air Emissions Program. Continued to assist with communications between WDOH, DOE-RL, and facilities regarding compliance questions, strategies, and permitting associated with radioactive air emission. In particular, assisted with communications regarding WDOH questions about 222-S stack cracks, CSB ventilation system compliance with American Society of Mechanical Engineers/ American 
National Standards Institute (ASME/ANSI) N510, T Plant sludge storage and Shipping-port fuel removal, and PFP's results of main stack sample line investigation.

- Assisted with finalizing assessment and strategy regarding response to the WDOH order calling for compliance with the annual calibration/functional testing of Magnehelic Differential Pressure (DP) Gages associated with radioactive airborne emissions abatement systems. Assistance involved input/review of compliance response package, and assisting with WDOH/DOE/contractor interface regarding the issues.

- Investigated/reported on regulatory/requirements basis for HNF-PRO-450's monthly source check required for continuous air monitors (CAMs) associated with National Emission Standards for Hazardous Air Pollutants (NESHAP) major stacks.

- Developed and published Regulatory Analysis Memorandum (RAM) 00-014 addressing regulation of onsite radioactive container transportation by the WDOH.

\section{Inspections/Assessments}

Regulatory Agency inspections and information requests were coordinated/facilitated at the following facilities:

- On October 19, 2000, inspectors from the Washington State Department of Ecology (Ecology) performed a Water Quality Inspection at the Fast Flux Test Facility (FFTF).

- On November 2, 2000, WDOH inspected the Canister Storage Building

- On November 6, 2000, Ecology performed a follow-on inspection of the 2714-U Drum at T Plant.

- On November 8, Ecology performed a follow-on inspection at FFTF.

- On November 8 and 9, 2000, Ecology performed an inspection of WSCF

Environmental compliance assessments were performed at the request of the following facilities:

- Central Waste Complex (sodium)

- 222-S Lab (Toxic Substance Control Act (TSCA) PCBs)

The notification letter to Ecology for the Fiscal Year 2001 Hanford Resources Conservation and Recovery Act Permit General Inspection schedule was completed as required by Permit Condition II.0.

\section{Crosscutting Compliance/lssue Resolution}

- A meeting was conducted to review efforts in assembling a complete file of the Silver List issues, which is a list of some Environmental Compliance Deficiencies, and to review current status of available forms. A letter is being prepared to formally respond to Ecology's request for information on the Silver List items.

- The Ecology's legal documentation they submitted to the Pollution Control Hearings Board (PCHB) concerning land disposal restriction (LDR) issues was reviewed. The FH legal counsel was supported in developing responses to Ecology's first set of interrogatory questions submitted to the PCHB that RL has to answer concerning LDR issues. The second 
set of interrogatory questions from Ecology was also reviewed.

- Site wide efforts continue on improvements to the RCRA contingency plan program.

Nineteen examples on how the recently negotiated "3-step criteria" for implementation of the contingency plan criteria were updated and placed out for review to site wide environmental and emergency preparedness personnel. In addition, draft permit conditions have been distributed for review in order to change the Hanford Facility RCRA Permit to be consistent with the new three-step criteria as well as documenting the process with Ecology for offering off site organizations copies of Hanford emergency preparedness documentation.

\section{Project Support}

- Analytical Services requested support on waste management issues at the laboratories in the areas of waste designation and land disposal restriction determinations. The first white paper has been drafted for the 222-S Laboratory concerning liquid analytical waste.

- The 219-S facility was assisted to determine applicability of 40 CFR Subpart BB requirements to their tank system and helped respond to $\mathrm{CHG}$ concerns over the introduction of acetonitrile/water mixture into the 219 -S vault tanks.

- Initiated assistance with a TSCA/PCB assessment of the 222-S laboratory procedures. Specific tasks include establishing flow-down of the "Mega-Rule" for accepting Tank Farm waste samples with the intent of analyzing them to determine PCB concentrations and therefore TSCA applicability.

\section{Environmental Notifications and Reporting}

- Regulatory reporting was coordinated for twenty-two (22) non-reportable releases of a hazardous substance and/or a petroleum product released to the environment. All of these releases were cleaned up and disposed of per state and federal requirements. There were no reportable events with a release to the environment. Two (2) reportable code non-compliance events and two (2) informational calls were reported directly to the regulators, and one (1) event which required a notification to the regulators per a regulatory agreement letter was made.

- The September 2000 NPDES report was compiled and submitted.

\section{Management and Administrative Support}

- The first draft of an ISO-14001 analysis white paper was completed. This paper compiles information regarding comparative benefits of self-declaration and registration to the international standard for environmental management systems. ISO-14001 elements are included in the FH Integrated Environmental, Safety and Health Management System (ISMS).

- Interpretive authority review/support was provided to document completion of the Standards/Requirements Identification Documents (S/RID) Phase II Assessment. The scope of this support verified applicable implementation of the site wide environmental protection (Chapter 20) S/RID overall requirements document within the Hanford Procedures (HNF$\mathrm{PRO}$ ) system. 


\section{Public Safety and Resource Protection (PSRP)}

- PNNL staff coordinated with Washington Department of Fish and Wildlife officials to estimate elk harvest for the current (2000) hunting season on lands adjacent to the Hanford Site. To date, over 100 animals have been taken and radio-equipped animal data suggest an additional 40 to $50(15 \%)$ animals may be lost from crippling.

- Major accomplishments for the Cultural Resources Project during October included:

- Sponsoring three Archaeology Month events

- Completing a new version of our cultural resource geographical information system and version 1.0 of our ACCESS Site form

- Completing the Native American Graves Protection and Repatriation Act documents for human remains;

- Conducting the cultural resource fire assessment work.

- Staff attended a Department of Energy (DOE) complex-wide (HQ and Field Offices) environmental monitoring workshop at Lawrence Livermore National Laboratory, October 24-27, to discuss issues facing other sites within the DOE complex. A presentation was made on the Hanford Fire and discussions were held on the Biological Dose Assessment Committee's draft standard on estimating biota dose.

- Staff attended the National Sample Management Office (SMO) Workshop in Oak Ridge Tennessee, October 17-19, to assess potential impacts of proposed actions on the Surface Environmental Surveillance Project (SESP) and to meet with Oak Ridge Environmental Monitoring staff.

Nothing to report at this time.

\section{ISMS STATUS}

\section{BREAKTHROUGHS / OPPORTUNITIES FOR IMPROVEMENT}

Nothing to report at this time.

\section{UPCOMING ACTIVITIES}

- The Annual Benton County Air Authority (BCAA) Asbestos Notification is due December $31,2000$.

- The Quarterly RCRA Permit Class I Modification Notification is due January 2, 2001.

- Work is in progress on the next Quarterly NESHAP Status Report, which is due on January 29, 2001. Efforts have also been initiated on the CY 2000 Hanford Site Annual Dangerous Waste Report and the CY 2000 EPCRA Tier II Emergency \& Hazardous Chemical Inventory Report; both reports are due to RL on February 21, 2001.

- The Annual Dangerous Wastes Reports and Tier II Emergency and Hazardous Chemical Inventories are due February 21, 2001.

- Ecology has again delayed issuance of Modification E of the Hanford Facility RCRA Permit (will incorporate WRAP and CWC units), and is now projecting this will occur after 
January 1, 2001. It has been proposed to Ecology that some of the positive permitting agreements that came out of the recent 222-S Part B Permit application workshops be considered in permit conditions prepared for Modification E. To date, Ecology has stated it will consider only the 222-S agreements in finalizing Modification E.

- Environmental Services will compile hazardous chemical information from the Hanford facilities to prepare the Tier Two Emergency and Hazardous Chemical Inventory Report, which is due February 21, 2001 (Milestone ECP-01-501).

- Environmental Services will compile the dangerous waste generation and Waste Management activities on site for the Hanford Annual Dangerous Waste Reports, which are due February 21, 2001 (Milestone ECP-01-503).

- The annual Surface Environmental Surveillance Project design review process has been initiated and will culminate with the revision and distribution of the "CY 2000 Hanford Site Environmental Surveillance Master Sampling Schedule" by the end of February 2001.

- Summaries of CY 2000 Biodiversity Plot Monitoring Data and the Sage Brush Die-Off observed during the previous fiscal year will be completed during March 2001.

- The annual "Climatological Data Summary Report for CY 2000" is scheduled for completion and distribution by the end of May 2001.

\section{Cost Performance (M):}

\begin{tabular}{|l|c|c|c|}
\hline & BCWP & ACWP & VARIANCE \\
\hline Mission Support 1.8.2 & $\$ 1.5$ & $\$ 1.1$ & $\$ 0.4$ \\
\hline
\end{tabular}

The $\$ 0.4$ million (24 percent) favorable cost variance is due to several factors. Further information at the PBS level can be found in the following Cost Variance Analysis details.

\section{SChedule Performance (M):}

\begin{tabular}{|l|c|c|c|}
\hline & BCWP & BCWS & VARIANCE \\
\hline Mission Support 1.8.2 & $\$ 1.5$ & $\$ 1.4$ & $\$ 0.1$ \\
\hline
\end{tabular}

The $\$ 0.1$ million ( 3 percent) favorable schedule variance is due to several factors. Further information at the PBS level can be found in the following Schedule Variance Analysis details. 
PHMC Environmental Management Performance Report-December 2000

Section I-Mission Support

\section{FY 2001 Cost/SChedule Performance - All Fund Types CuMulative to Date STATUS - $(\$ 000)$}

By PBS

\begin{tabular}{llllllll}
\hline BCWS & BCWP & ACWP & SV & $\%$ & CV & $\%$ & PEM
\end{tabular}

PBS OT01

WBS 1.8 .2

Mission

$\begin{array}{llllllllllllll}\text { Support Other } & \$ & 1,438 & \$ & 1,482 & \$ & 1,131 & \$ & 44 & 3.1 \% & \$ & 352 & 23.72 \% & \$ 24,052\end{array}$

MYPs

Total

$\begin{array}{lllllllllllll}\$ & 1,438 & \$ & 1,482 & \$ & 1,131 & \$ & 44 & 3.1 \% & \$ & 352 & 23.72 \% & \$ 24,052\end{array}$

\section{COST/SCHEDUle PERformanCE INDICES (MONTHLY AND FYTD)}

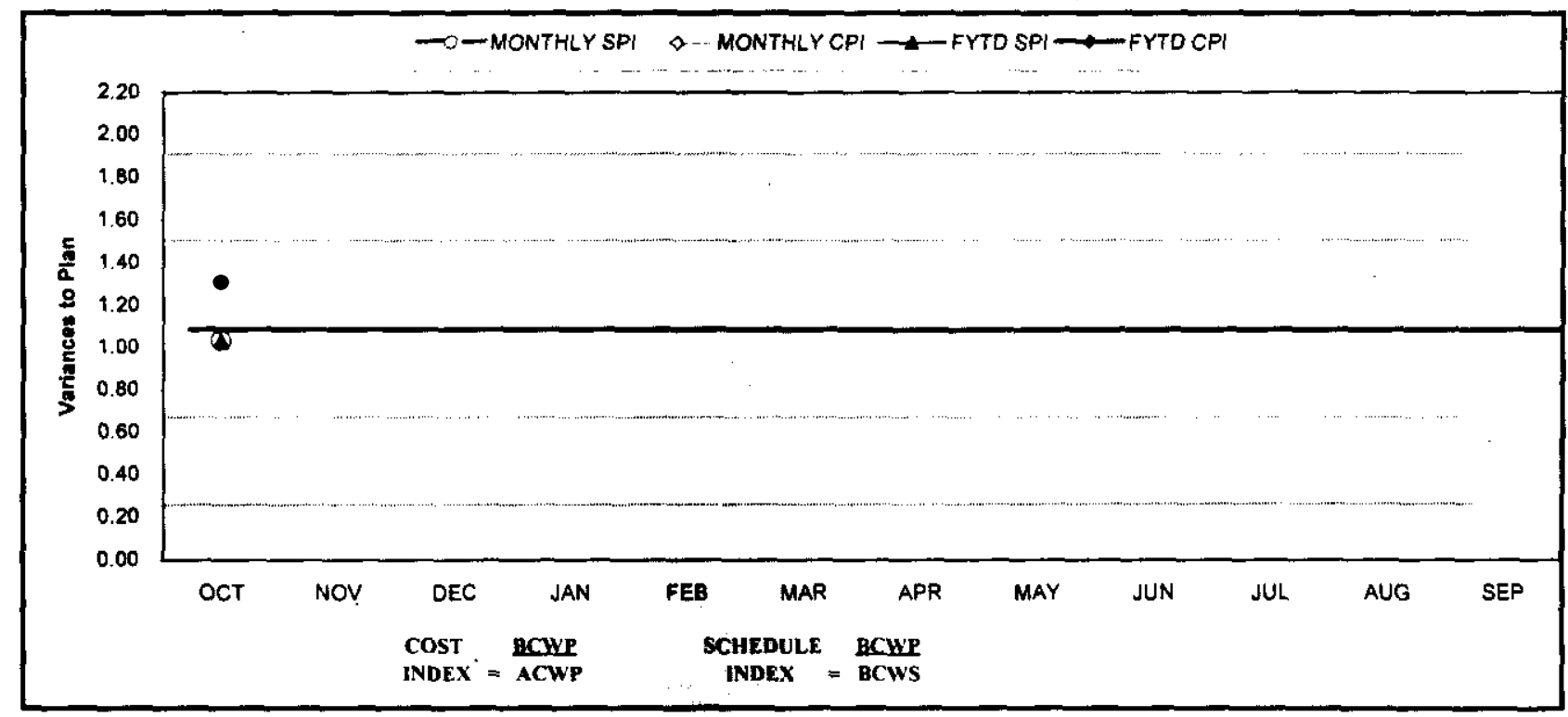

\begin{tabular}{|c|c|c|c|c|c|c|c|c|c|c|c|c|}
\hline FY 2001 & OCT & NOV & DEC & JAN & FEB & MAR & $\mathbf{A P R}$ & MAY & JUN & JUL & AlIG & SEP \\
\hline MONTHLY SPI & 1.03 & & & & & & & & & & & \\
\hline MONTHLY CPI & 1.31 & & & & & & & & & & & \\
\hline FYTD SPI & 1.03 & & & & & & & & & & & \\
\hline FYTD CPI & 1.31 & & & & & & & & & & & \\
\hline MONTHLY BCWS & $\$ 1.438$ & $\$ 1.955$ & $\$ 1.934$ & $\$ 2.019$ & $\$ 1,830$ & $\$ 2,008$ & $\$ 2,114$ & $\$ 2.379$ & $\$ 1.896$ & 51.914 & $\$ 2.214$ & $\$ 2,351$ \\
\hline MONTHLY BCWP & 51.482 & & & & & & & & & & & \\
\hline MONTHL Y ACWP & 51.131 & & & & & & & & & & & \\
\hline FYTD BCWS & $\$ 1,438$ & $\$ 3,393$ & $\$ 5,327$ & $\$ 7,346$ & 59.175 & $\$ 11,183$ & $\$ 13,297$ & $\$ 15,676$ & $\$ 17,572$ & $\$ 19.487$ & $\$ 21,701$ & $\$ 24.052$ \\
\hline FYTD BCWP & $\$ 1.482$ & & & & & & & & & & & \\
\hline FYTD ACWP & $\$ 1.131$ & & & & & & & & & & & \\
\hline
\end{tabular}

\section{COST VARIANCE ANALYSIS: $(\$ 0.4 \mathrm{M})$}

\section{WBS/PBS}

1.8.2/0T01

reasons listed below.

\section{Title}

\section{Mission Support}


1.8.2.1 - October accruals were not made for Fluor Federal Services, Mactec or Westec, because their contracts were not agreed to in time for month-end processing.

1.8.2.3 - 1. ECP WSCF sample analysis, fleet, and duplicating costs were not included in cost reports due to the cost feed to Fluor Unit Rate (FUR) failing at month end. 2. Accrual reversals for FY-2000 contract accruals for which we have still not received invoices or the invoices were not cost processed before month end deadlines.

1.8.2.4 - 1. Outstanding analytical charges that have not yet been recorded in the PNNL financial system. 2. A large number of staff took vacation in October. 3. FY 2000 accruals that had not been reversed as of the end of October.

Impact: No impact.

Corrective Action: No corrective action required.

\section{SCHEDULE VARIANCE ANALYSIS: (\$0.1M)}

$\underline{\text { WBS/PBS }}$

1.8.2/OT01

Description/Cause: The $\$ 0.1$ million ( 3 percent) favorable schedule variance is within acceptable reporting thresholds.

Impact: No impact.

Corrective Action: No corrective action required.

\section{ISSUES}

Reconciliation of FH Project Cost Baselines - In reconciling Program Baseline Summary (PBS) life cycle cost baselines reflected in the DOE-HQ Integrated Planning and Budgeting System (IPABS), with baselines provided in the RL Summary Schedule, it became apparent that some increased discipline is needed to maintain life cycle baselines consistent with approved baseline changes. The inconsistencies hamper FH Project Controls in providing RL and DOEHQ with accurate baseline data in support of the proposed PBS restructure.

Corrective Action/Status: Project Controls continues to work with Projects to complete the needed baseline reconciliation. This issue will be on the agenda for the newly established Project Controls Leadership Forum meeting scheduled November 30, 2000. 


\section{Baseline Chance Requests Currently in Process $(\$ 000)$}

\begin{tabular}{|c|c|c|c|c|c|c|c|c|c|}
\hline $\begin{array}{l}\text { PPBONECT CHANGE } \\
\text { NLMBER }\end{array}$ & $\begin{array}{l}\text { DATE } \\
\text { ORIGIN }\end{array}$ & BCRTTTLE & $\begin{array}{l}\text { NO0 } \\
\text { COST } \\
\text { IMPACT } \\
\text { S000 }\end{array}$ & SCH & TECH & $\begin{array}{l}\text { DATE TO } \\
\text { OCB }\end{array}$ & $\begin{array}{c}\text { OCB } \\
\text { APR'VD }\end{array}$ & RL $\quad$ APR'VD & $\begin{array}{l}\text { CIRRENT } \\
\text { STATLS }\end{array}$ \\
\hline SPl-2000-008 & $7 / 28 / 00$ & $\begin{array}{l}\text { Baseline Modifications to Support FY } \\
\text { 2001 MYWP Update }\end{array}$ & & & & & & & In Progress \\
\hline SSE-2000-002 & $10 / 18 / 99$ & FY 99 Caryover & & & & & & & RWOA-F \\
\hline SSE-2000-004 & $7 / 26: 00$ & FY 2000 to FY $2001 \mathrm{BCR}$ & & & & & & & in Progress \\
\hline ECP-2000-003 & $12 / 15 / 00$ & $\begin{array}{l}\text { Utilization of ECP FY - } 99 \text { Uncosted } \\
\text { Canyover }\end{array}$ & $\$ 449$ & & & & & & RWOA-F \\
\hline $\mathrm{FH}-2001-001$ & $9 / 12 / 00$ & Base Ops Reduction for PHMC Projects & $-\$ 535$ & & $\mathrm{X}$ & & & & $\begin{array}{l}\text { Draft } \\
\text { Prepared }\end{array}$ \\
\hline $\mathrm{FH}-2001-002$ & 9/25/00 & & $-\$ 129$ & & & & & & $\begin{array}{l}\text { Draft } \\
\text { Prepared }\end{array}$ \\
\hline PSR-2000-003 & $8 / 17 / 00$ & $\begin{array}{l}\text { Revise Cultural resources Baseline to } \\
\text { delete Soope due to Holdback of Funding } \\
\text { for DOE-RL Intem }\end{array}$ &.$\$ 50$ & & & $08 / 2200$ & $08 / 22 / 00$ & & In Progress \\
\hline \multicolumn{10}{|c|}{ ADVANCE WORG ALTTHORIZATIONS } \\
\hline & & Nothing to report. & & & & & & & \\
\hline & & & & & & & & & \\
\hline
\end{tabular}

\section{MILESTONE ACHIEVEMENT}

\begin{tabular}{|c|c|c|c|c|c|c|c|c|}
\hline \multirow[b]{2}{*}{ MILESTONE TYPE } & \multicolumn{4}{|c|}{ FISCAL YEAR-TO-DATE } & \multicolumn{3}{|c|}{ REMAINING SCHEDULED } & \multirow[b]{2}{*}{$\begin{array}{l}\text { TOTAL } \\
\text { FY } 2001\end{array}$} \\
\hline & $\begin{array}{c}\text { Completed } \\
\text { Early }\end{array}$ & $\begin{array}{c}\text { Completed } \\
\text { On } \\
\text { Schedule }\end{array}$ & $\begin{array}{c}\text { Completed } \\
\text { Late }\end{array}$ & Overdue & $\begin{array}{c}\text { Forecast } \\
\text { Early }\end{array}$ & $\begin{array}{c}\text { Forecast } \\
\text { On } \\
\text { Schedule }\end{array}$ & $\begin{array}{c}\text { Forecast } \\
\text { Late }\end{array}$ & \\
\hline Enforceable Agreement & 0 & 1 & 0 & 0 & $\overline{0}$ & 3 & 0 & $\overline{4}$ \\
\hline$\overline{D O E}-\mathrm{HQ}$ & 0 & 0 & 0 & $\overline{0}$ & $\overline{0}$ & 0 & 0 & 0 \\
\hline $\mathrm{RL}$ & 0 & 0 & D & $\overline{0}$ & $\overline{0}$ & 1 & $\overline{0}$ & 1 \\
\hline Total Project & 0 & 1 & 0 & 0 & 0 & 4 & 0 & 5 \\
\hline
\end{tabular}

Only TPA/EA milestones and all FY 2001 overdue and forecast late milestones are addressed in this report. Milestones overdue are deleted from the Milestone Exception Report once they are completed. The following chart summarizes the FY 2001 TPA/EA milestone achievement and a Milestone Exception Report follows. 
PHMC Environmental Management Performance Report-December 2000

Section I-Mission Support

\begin{tabular}{|c|l|c|c|}
\hline \multicolumn{3}{|c|}{ FY 2001 Tri-Party Agreement / EA Milestones } \\
\hline Number & \multicolumn{1}{|c|}{ Milestone Title } & Baseline Date & $\begin{array}{c}\text { Actual } \\
\text { Completion } \\
\text { Date/Status }\end{array}$ \\
\hline ECP-01-901 & $\begin{array}{l}\text { Issue Quarterly NESHAP Status Report to RL } \\
\text { for EPA }\end{array}$ & $10 / 20 / 2000$ & $10 / 17 / 2000$ \\
\hline ECP-01-902 & $\begin{array}{l}\text { Issue Quarterly NESHAP Status Report to RL } \\
\text { for EPA }\end{array}$ & $1 / 29 / 2001$ & \\
\hline ECP-01-904 & $\begin{array}{l}\text { Issue Quarterly NESHAP Status Report to RL } \\
\text { for EPA }\end{array}$ & $4 / 2 / 2001$ & \\
\hline ECP-01-906 & $\begin{array}{l}\text { Issue Quarterly NESHAP Status Report to RL } \\
\text { for EPA }\end{array}$ & $8 / 31 / 2001$ & \\
\hline \multicolumn{3}{|c|}{ DNFSB Commitments } \\
\hline & Nothing to report at this time. & \\
\hline
\end{tabular}

\section{MILESTONE EXCEPTION REPORT}

Nothing to report at this time.

\section{Performance Objectives}

Nothing to report at this time.

\section{KEY INTEGRATION ACTIVITIES}

Specific components of the PS\&RP Program are identified as a critical core project within the Groundwater/Vadose Zone Integration Project. As such, key activities relevant to both programs were integrated into FY 2001 detailed work plans as appropriate. 
PHMC Environmental Management Performance Report - December 2000

Section J-National Programs

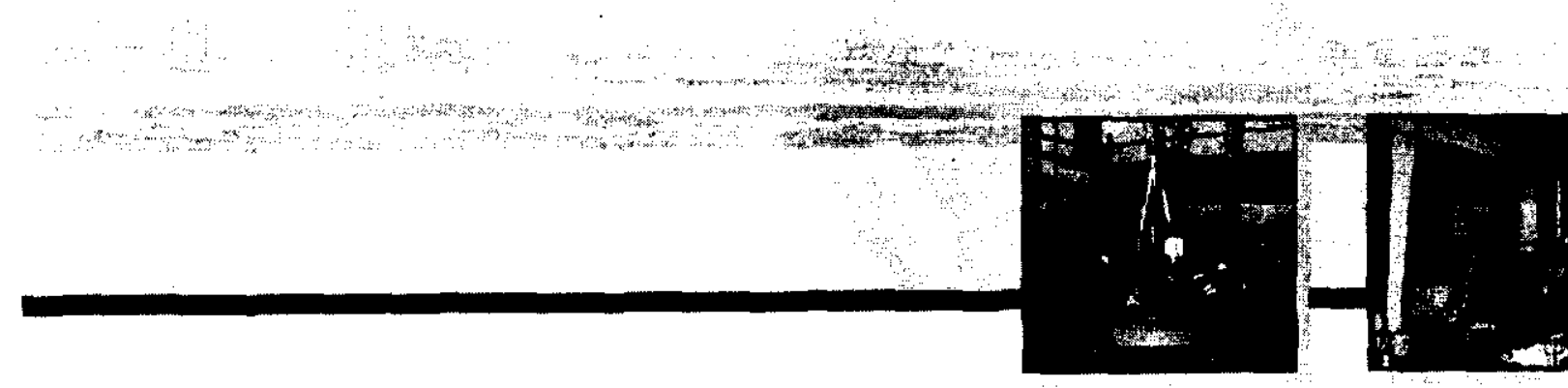

Section J

National Programs 


\section{SUMMARY}

DOE EM is responsible for a variety of National Programs. DOE-HQ typically provides operations policy and programmatic guidance to one or more field office that serve as lead for individual programs. FH currently supports the following National Programs: Transportation and Packaging (PBS OT02) and Pollution Prevention and Waste Minimization (PBS WM07).

Transportation and Packaging provides full-service transportation and packaging capabilities. Packaging services for radioactive and hazardous cargo is provided, including regulatory safetybasis documentation, certification, and licensing. Packaging plans and logistical studies for major shipping campaigns are also provided, as well as approved training courses in transportation safety and waste management. Transportation and traffic logistics management, engineering and operational support to offsite customers, carrier selection and evaluation, automated transportation management systems used by the U.S. Department of Energy (DOE) complex and commercial vendors, and international transport of hazardous and radioactive packages are other services provided.

Pollution Prevention and Waste Minimization (P2/WMin) coordinates the development and implementation of a Hanford Site P2/WMin Program to comply with Federal, state, and DOE directives. The program's purpose is to achieve Site objectives through effective and efficient methodologies tailored to generator activities and operations.

\section{Accomplishments}

- The PHMC has met the FY 2000 P2/WMin Comprehensive PI waste reduction, sanitary waste recycling and Affirmative Procurement goals.

- Compilation of P2 quarterly report data for the fourth quarter of FY 2000 was completed, reviewed and approved by $R L$, and submitted to EM-22. This completes one portion of Milestone YP2-01-001. The following waste reductions were reported:

$\begin{array}{ll}\text { - } & \text { LLW }-3,535 \mathrm{~m}^{3} \\ \text { - } & \text { MLLW }-23.16 \mathrm{~m} 3 \\ \text { - } & \text { Hazardous Waste }-63.23 \mathrm{mt} \\ \text { - } & \text { Wanitary Waste }-276.8 \mathrm{mt} \\ \text { - } & \text { WW-LLW }-25.0 \mathrm{~m}^{3} \\ \text { - } & \text { WW-SAN }-185.2 \mathrm{~m}^{3}\end{array}$

Total reported cost savings were $\$ 12,537,797$. 
Fy 2001 Cost/SChedule Performance - All Fund Types Cumulative to Date STATUS - $(\$ 000)$

FYTD

By PBS

PBS OT02 Transportation \&

WBS 1.11.1 Packaging (RL 7601)

PBS WM07 Waste Minimization

WBS 1.11.2 (RLHQ 7770)

Total

\begin{tabular}{llllllll}
\hline BCWS & BCWP & ACWP & SV & $\%$ & CV & $\%$ & PEM
\end{tabular}

$\begin{array}{llllllll}\$ & 115 & \$ & 116 & \$ & 10 & \$ & 0\end{array}$

$0 \% \$(98) \quad-85 \% \$ 2,136$

\section{Cost/SChedule Performance INDices (MONTHLY AND FYTD)}

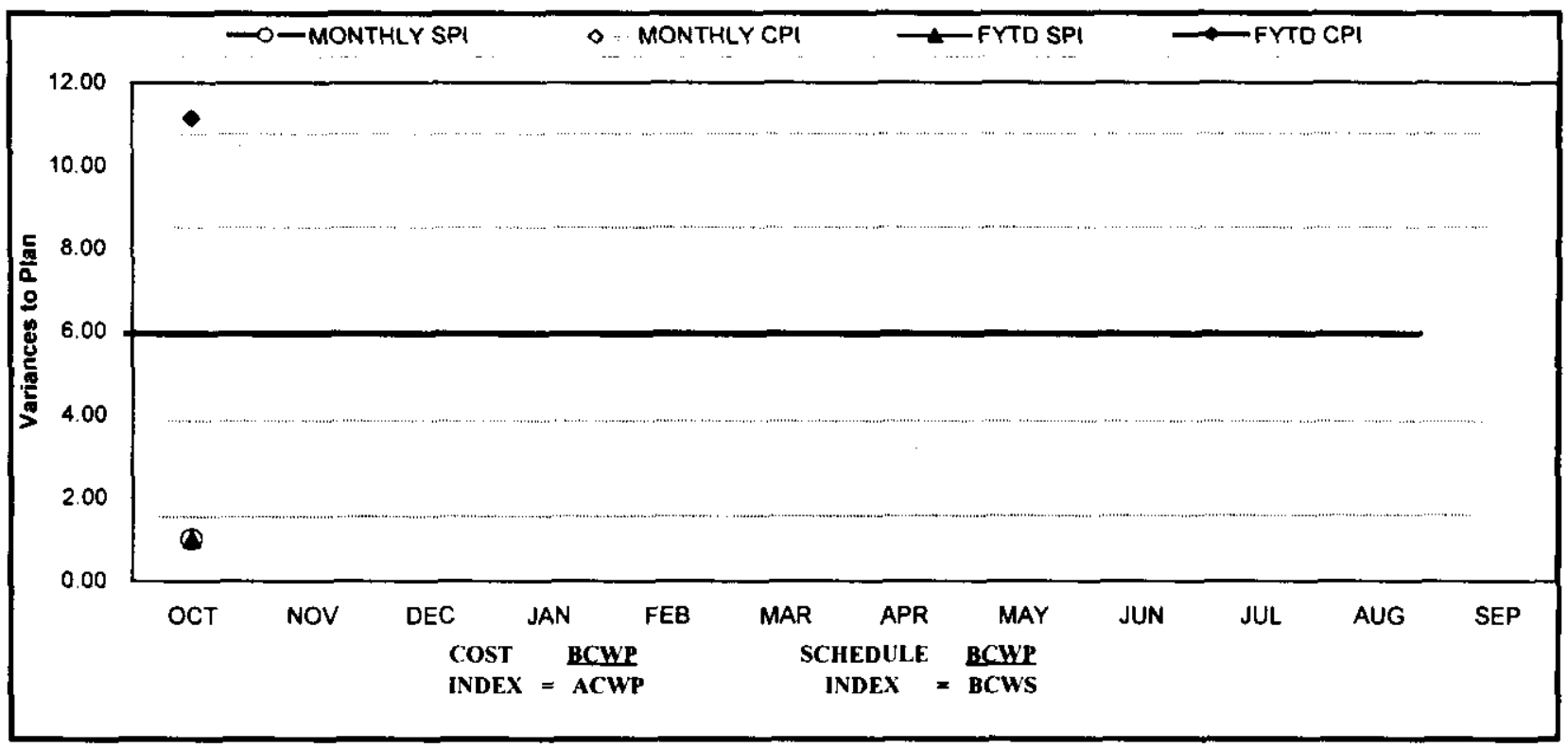

\begin{tabular}{|c|c|c|c|c|c|c|c|c|c|c|c|c|}
\hline FY 2001 & OCT & NOV & DEC & JAN & FEB & MAR & APR & MAY & $\mathrm{JUN}$ & JUL & AUG & SEP \\
\hline MONTHLY SPI & 1.00 & & & & & & & & & & & \\
\hline MONTHLY CPI & 11.16 & & & & & & & & & & & \\
\hline FYTD SPI & 1.00 & & & & & & & & & & & \\
\hline FYTD CPI & 11.16 & & & & & & & & & & & \\
\hline MONTHLY BCWS & $\$ 115$ & 188 & 164 & 151 & 99 & 103 & 93 & 113 & 86 & 86 & 101 & 836 \\
\hline MONTHLY BCWP & \begin{tabular}{l|l}
5 & 116 \\
\end{tabular} & & & & & & & & & & & \\
\hline MONTHLY ACWP & 10 & & & & & & & & & & & \\
\hline FYTD BCWS & 5115 & $5 \quad 303$ & 467 & 618 & 717 & 820 & 913 & 1,026 & $\$ \quad 1,112$ & S 1.198 & $s \quad 1.300$ & 2.136 \\
\hline FYTD BCWP & \begin{tabular}{|l|l}
5 & 116 \\
\end{tabular} & & & & & & & & & & & \\
\hline FYTD ACWP & $\$ 10$ & & & & & & & & & & & \\
\hline
\end{tabular}




\section{COST VARIANCE ANALYSIS: (-\$0.1M)}

WBS/PBS

1.11.1/OT02
Title

Transportation and Packaging

Description and Cause: Unfavorable cost variance is due to progress not recording in the performance tracking system software.

Impact: None.

Corrective Action: Data will be loaded for next reporting period.

\section{SCHEDUle VARIANCE ANALYSIS: (+\$0.0M)}

\section{WBS/PBS $\quad$ Title}

\subsection{1/OT02 Transportation and Packaging}

Description and Cause: No schedule variance is due to progress not recording in the performance tracking system software.

Impact: None.

Corrective Action: Data will be loaded for next reporting period. 


\section{Richland Operations Office Environmental Restoration \\ Environmental Management Performance Report}

\section{December 2000}

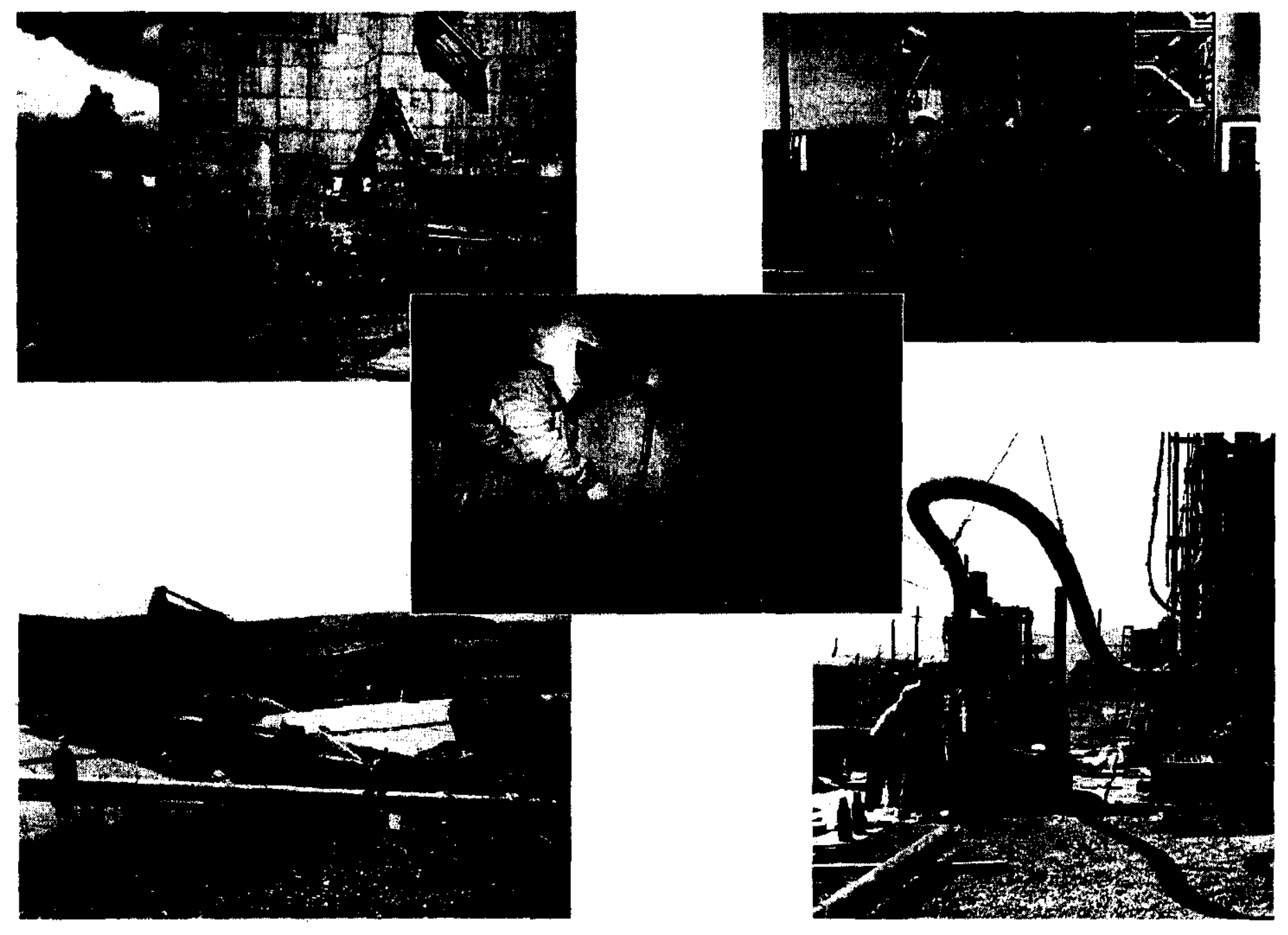

Focused on Progress... Focused on Outcomes! 


\section{ENVIRONMENTAL MANAGEMENT PERFORMANCE REPORT \\ ENVIRONMENTAL RESTORATION \\ DECEMBER 2000}

\section{TABLE OF CONTENTS}

INTRODUCTION 1

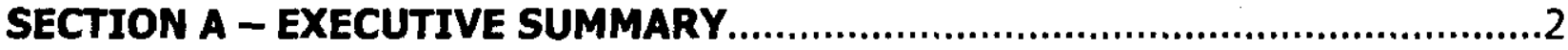

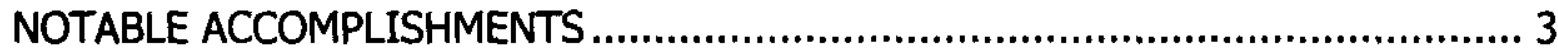

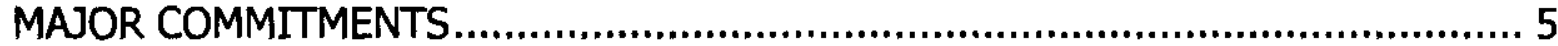

SAFETY/ISMS/CONDUCT OF OPERATIONS ............................................... 6

REGULATORY/EXTERNAL/DOE-RL \& HQ ISSUES AND REQUESTS ....................12

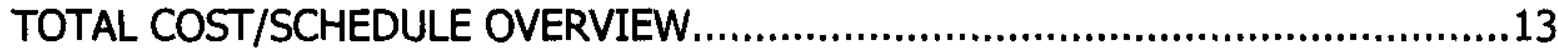

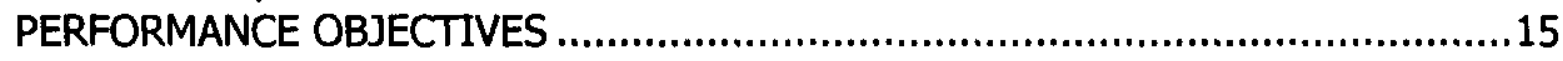

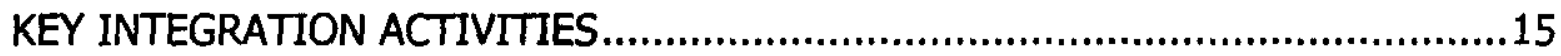

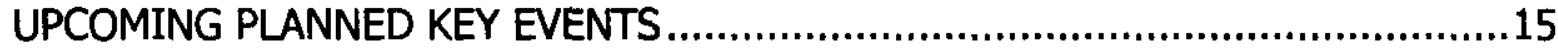

SECTION B - RESTORING THE RIVER CORRIDOR PROJECT SUMMARIES.....,16

REMEDIAL ACTION AND WASTE DISPOSAL PROJECT ….............................17

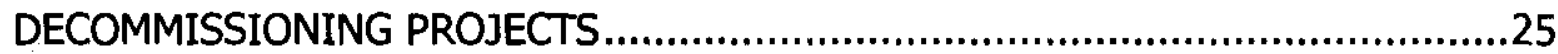

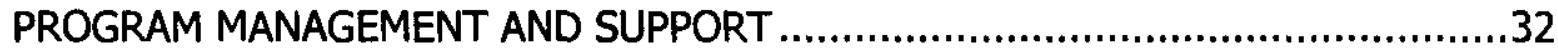

\section{SECTION C - TRANSITIONING THE CENTRAL PLATEAU PROJECT} SUMMARIES

GROUNDWATER/VADOSE ZONE INTEGRATION PROJECT ..................................39

SURVEILLANCE/MAINTENANCE AND TRANSITION PROJECTS ............................49 


\section{ENVIRONMENTAL MANAGEMENT PERFORMANCE REPORT ENVIRONMENTAL RESTORATION \\ DECEMBER 2000}

\section{INTRODUCTION}

The monthly Environmental Restoration (ER) Environmental Management Performance Report consists of three sections: Section A - Executive Summary, Section B - Restoring the River Corridor Project Summaries, and Section C - Transitioning the Central Plateau Project Summaries. All cost, schedule, milestone commitments, performance measures, and safety data is current as of October 31. Accomplishments, Issues and Integration items are current as of November 30 , unless otherwise noted.

Section A - Executive Summary. This section provides an executive level summary of Bechtel Hanford, Inc.'s (BHI) performance information for the current reporting month and is intended to bring to Management's attention that information considered to be most noteworthy. The Executive Summary begins with a description of notable accomplishments that are considered to have made the greatest contribution toward safe, timely, and cost-effective cleanup. Major commitments are summarized that encompass Hanford Federal Facility Agreement and Consent Order (Tri-Party Agreement) milestones, FYO1 management commitment milestones, and Environmental Management (EM) corporate performance measures. Safety statistics are also included. Issues that require management and/or regulator attention and resolution status are addressed. Fiscal year-to-date ERC Project cost and schedule variance analysis is summarized. The Key Integration Activities section highlights site activities that cross contractor boundaries and demonstrates the shared value of working as a team to accomplish the work. The Executive Summary ends with a listing of major upcoming planned key events within a 90 -day period.

Section B - Restoring the River Corridor. This section contains more detailed monthly activity information and performance status for the three projects within the 'Restoring the River Corridor' outcome. These three projects consist of the Remedial Action and Waste Disposal (RAWD) Project, Decommissioning Projects, and the Program Management and Support (PM\&S) Project.

Section C - Transitioning the Central Plateau. This section contains more detailed monthly activity information and performance status for the two projects within the 'Transitioning the Central Plateau' outcome. These two projects consist of the Groundwater/Vadose Zone (GW/VZ) Integration Project and the Surveillance/Maintenance and Transition (SM\&T) Projects.

Information in this report is identified with a green, yellow, or red text box used as an indicator of the overall status. Green indicates work or issue resolution is satisfactory and generally meets or exceeds requirements; yellow indicates that significant improvement is required; and red indicates unsatisfactory conditions requiring immediate corrective actions. 


\section{Section A:




\section{ENVIRONMENTAL MANAGEMENT PERFORMANCE REPORT ENVIRONMENTAL RESTORATION \\ DECEMBER 2000}

\section{SECTION A - EXECUTIVE SUMMARY}

Financial / Performance Measisis data as of month-end Octobei.

All other data as of November 30, 2000 (unless otherwise noted).

NOTABLE ACCOMPLISHMENTS:

\section{RTVER CORRIDOR;}

Hydroseeding was completed over the interim cover of the Environmental Restoration Disposal Facility (ERDF) Cells \#1 and \#2 during October. These two cells were filled with waste from Environmental Restoration (ER) remediation activities between mid-FY96 and mid-FYOO.

The $100 \mathrm{~B} / \mathrm{C}$ Area pipeline remediation contract was awarded on November 28. A Hanford Federal Facility Agreement and Consent Order (Tri-Party Agreement) change request was forwarded to the regulators on October 19 proposing a new milestone date be established by January 31, 2001.

Laboratory results were received that indicated chromium +6 levels in the 1000 Area were below the cleanup level established in the $K d$ study. The regulators agreed to proceed with backfill and closeout operations. The subcontractor is scheduled to return in mid-December to complete the backfill of the remaining sites.

Extensive planning, including a dryrun and readiness evaluation, was performed prior to lifting the first 116-N-3 crib cover panel (located in $100 \mathrm{~N}$ Area) on October 30. A 200-ton crane was mobilized that is being used to individually lift the 420 panels. The panels are being removed so soil remediation of the contaminated trench can commence.

Design continued for the remediation of the J.A. Jones and 600-23 waste sites in support of the Columbia River Corridor Initiative. The draft design was submitted for review, and comments were received and are being incorporated. Bids were requested for the J.A. Jones and 600-23 sites on November 16, and are due on November 30.

During October, demolition and loadout were completed for the $F$ Reactor fuel storage basin (FSB) above-grade structure, transfer bay, and rear-face stairwells. At DR Reactor, demolition was also completed for the rear-face stainwells, and loadout is in progress. Backfill was completed for DR Reactor FSB and valve pit areas.

On October 17, the action memorandum for 0 and $H$ Reactors ISS was approved by the regulators.

Decommissioning activities in the 233-5 Plutonium Concentration Facility was centered around the $L-18$ vessel removal during October. Electrical conduit removal was initiated, along with low-point liquid checks in the piping. The $L-18$ vessel structure is approximately four stories high.

A release plan was established for 2,500 lead bricks at a $100 \mathrm{H}$ Area remediation waste site. This release plan is a result of a consent agreement and final order issued by the EPA, Region 10 to close out the findings of the 1998 multi-media inspection. Each of the 2,500 lead bricks will be surveyed and released in accordance with the requirements set forth in DOE Order 5400.5 (Radiation Protection of the Public and Environment) and all applicable DOE Secretarial memoranda addressing the release of such material.

On October 10-11, ER participated in the "Hanford 2012: Accelerating Cleanup and Shrinking the Site" workshop that was conducted for the Hanford Advisory Board (HAB) Committee members. The workshop was held to provide a better understanding of the drivers, assumptions, and key policy issues underlying RL's new management direction for site cleanup. 


\section{ENVIRONMENTAL MANAGEMENT PERFORMANCE REPORT ENVIRONMENTAL RESTORATION \\ DECEMBER 2000}

\section{NOTABLE ACCOMPLISHMENTS continued:}

Work progressed in developing the ER Project Baseline Update (multi-year work plan) that is scheduled for completion on December 15.

The FYOO ER Project year-end status was presented to HQ during their FYOO year-end briefing held in mid-November.

\section{CENTRAL PLATEAU:}

The Groundwater/Vadose Zone (GW/V) Integration Project conducted the eighth meeting with the Integration Project Expert Panel. This meeting focused on Columbia River issues and resolutions.

Historical matching was initiated with the GWNZ System Assessment Capability (SAC) Rev. 0 capability. The purpose of historical matching is to assess the ability of SAC Rev. O predictions to match observations and identify improvements needed prior to the initial assessment.

During FYOO, all ten wells planned for the In Situ Redox Manipulation (ISRM) Project were chemically injected, and chemical barrier withdrawal for two wells was completed during October. Only one well remains to complete withdrawal activities, which is scheduled for completion in December.

A Resource Conservation and Recovery ACt (RCRA) well installation workshop was held on October 4 with Ecology, RL, Office of River Protection (ORP), and contractors. The list of recommended wells for installation in calendar year 2001 to support the Tri-Party Agreement M-24 milestone was presented to Ecology.

During October, two boreholes were drilled, and grab samples were submitted for analysis in support of the tritium investigation associated with the 618-11 Buria/ Ground.

All five groundwater pump and treat systems operated above the planned $90 \%$ availability levels in October. Since system inception, the five pump and treat systems have processed over 4.4 billion liters of groundwater, removing approximately 4,713 kilograms of carbon tetrachloride, 202 kilograms of chromium, and 0.91 curies of strontium.

Surveillance and maintenance (S\&M) activities completed at B Reactor included completing leaking roof repairs and asbestos repairs. Significant deterioration in the asbestos insulation on several pipes running across the roof of $B$ Reactor was discovered during vent sealing on the reactor roof. Work is also progressing on the $B$ Reactor engineering evaluation/cost analysis (EE/CA) document.

A total of nine concrete coring samples were obtained from process cells located in U Plant in support of the Canyon Disposition Initiative (CDI). These samples were successfully ground into a slurry for analytical review. Sample contamination and dose rates were low enough that the work was accomplished in the canyon without a glove box. 


\section{ENVIRONMENTAL MANAGEMENT PERFORMANCE REPORT ENVIRONMENTAL RESTORATION \\ DECEMBER 2000}

\section{MAJOR COMMITMENTS:}

Tri-Party Agreement Milestones:

Fourteen TPA milestones are planned for completion during FY01. Through October, one milestone, M-24-46 "Install Two Additional Wells at SST WMA S-SX" (due December 31), was completed on September 14, fifteen weeks ahead of schedule. Two milestones are unrecoverable. A TPA change request is nearing approval that establishes a revised completion date for M-16-26B, "Complete Remediation, Backfill, and Revegetation of 51 Liquid Waste Sites and Process Effuent Pipelines in the 100 BC, 100 DR, and 100 HR Operable Units" (due February 28, 2001). A TPA change request will be prepared for M-16-26C, "Complete Remediation and Backfill of 10 Liquid Waste Sites and Process Effuent Pipelines in the 100-HR-1 Operable Unit" (due May 31, 2001), when impacts of the elevated chromium levels have been evaluated.

\begin{tabular}{|l|c|}
\hline Total Tri-Party Agreement Milestones Due in FY01 & 14 \\
\hline Total Planned Through October & 0 \\
\hline Total Completed Through October & 1 \\
\hline
\end{tabular}

\begin{tabular}{|l|c|}
\hline Remaining Tri-Party Agreement Milestones to be Completed in FY01 & 13 \\
\hline Forecast Ahead of Schedule & 6 \\
\hline Forecast On Schedule & 5 \\
\hline Forecast Unrecoverable & 2 \\
\hline
\end{tabular}

EM Corporate Performance Measures:

\begin{tabular}{|l|c|c|c|c|c|}
\cline { 2 - 4 } & $\begin{array}{c}\text { DWP } \\
\text { FY01 }\end{array}$ & $\begin{array}{c}\text { FY01 Mgmi } \\
\text { Commitments }\end{array}$ & $\begin{array}{c}\text { Current } \\
\text { Baseline }\end{array}$ & $\begin{array}{c}\text { Forecast } \\
\text { for FY01 }\end{array}$ & $\begin{array}{c}\text { Completed } \\
\text { YTD }\end{array}$ \\
\hline $\begin{array}{l}\text { Waste Site } \\
\text { Excavations }\end{array}$ & 12 & 12 & 14 & 14 & 0 \\
\hline $\begin{array}{l}\text { *Technology } \\
\text { Deployments }\end{array}$ & 0 & & & & \\
\hline
\end{tabular}

*A technology deployment plan will be developed in January 2001 as identified in the DWP. 


\section{ENVIRONMENTAL MANAGEMENT PERFORMANCE REPORT ENVIRONMENTAL RESTORATION \\ DECEMBER 2000}

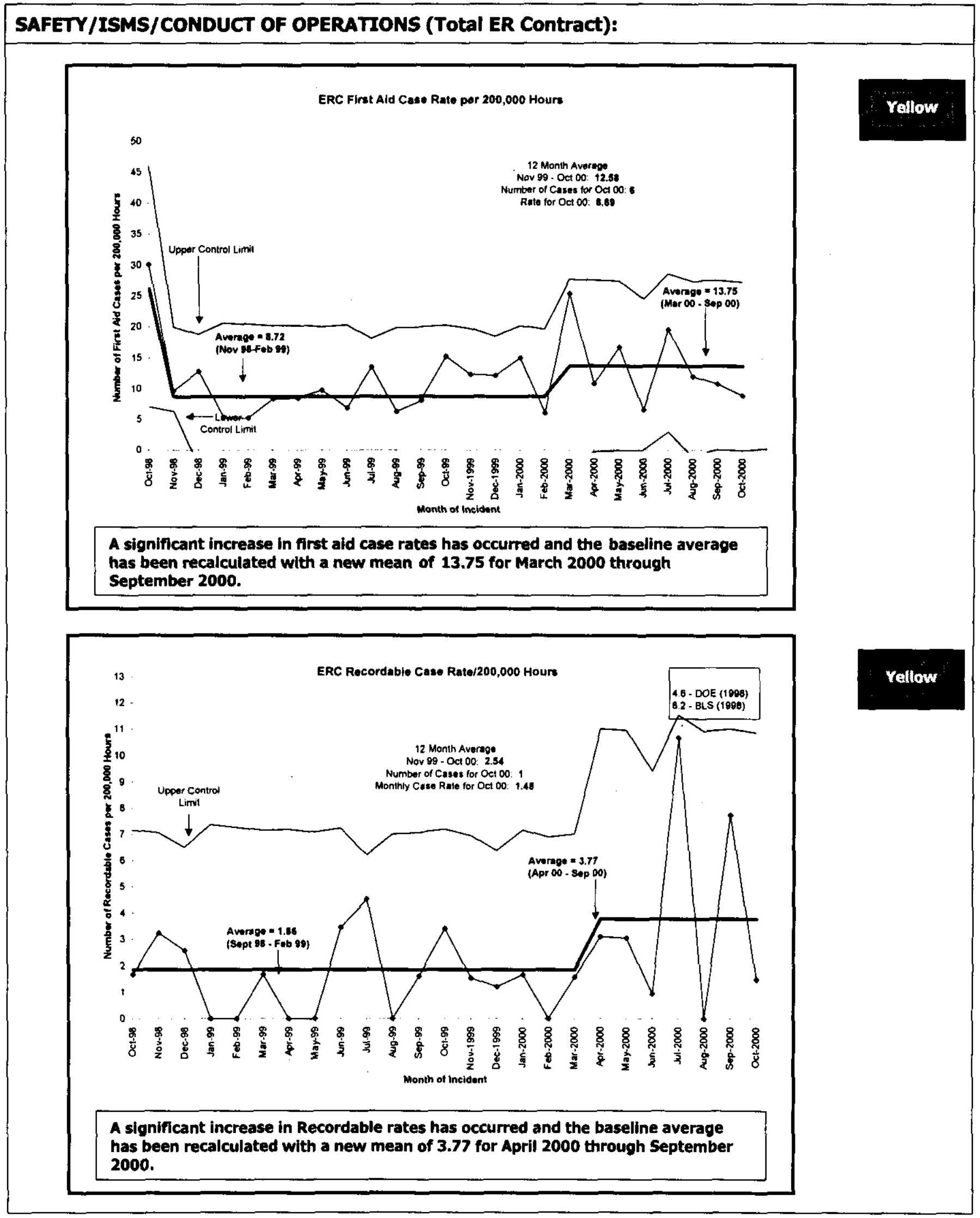




\section{ENVIRONMENTAL MANAGEMENT PERFORMANCE REPORT ENVIRONMENTAL RESTORATION \\ DECEMBER 2000}

\section{SAFETY/ISMS/CONDUCT OF OPERATIONS (Total ER Contract) continued:}

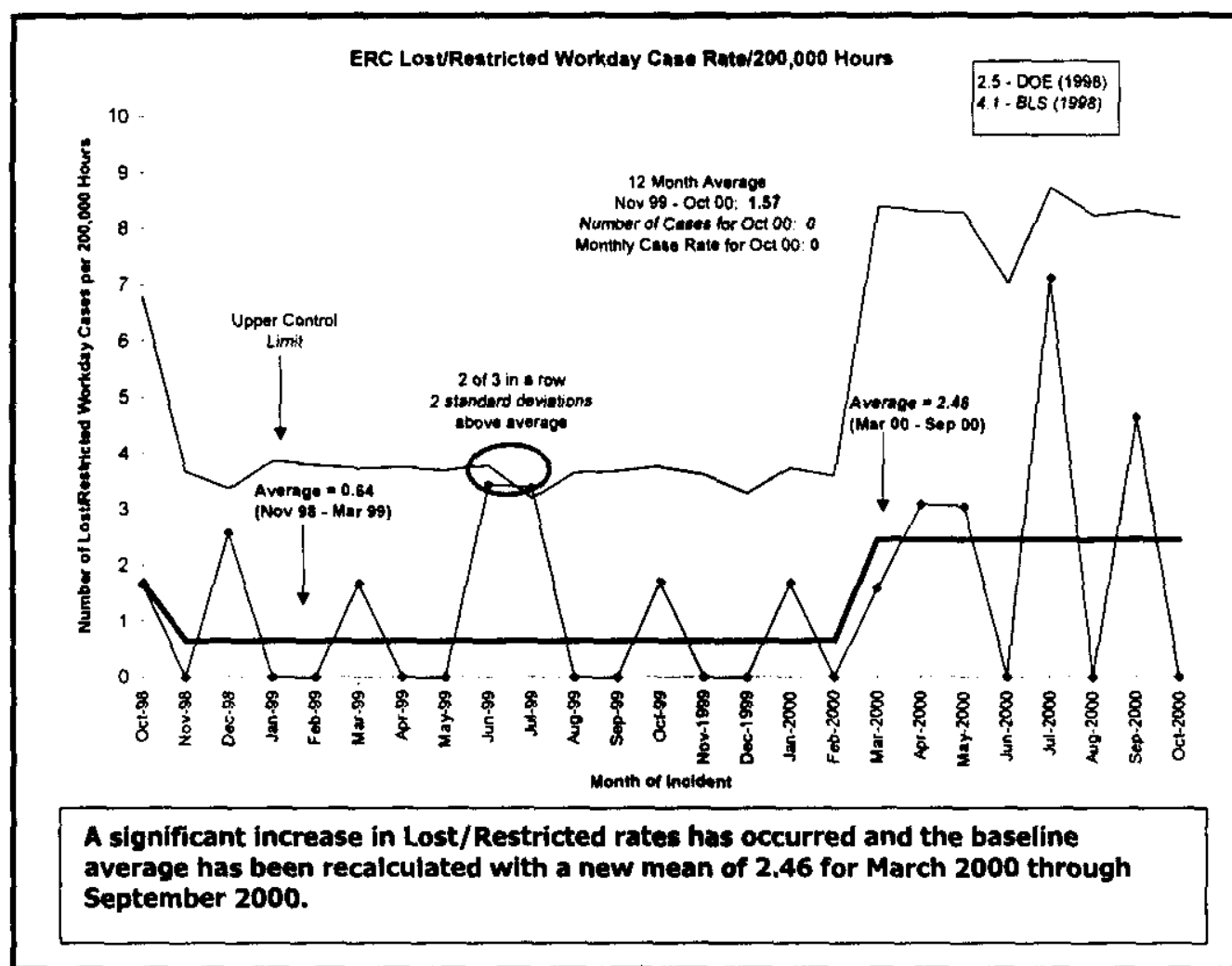




\section{ENVIRONMENTAL MANAGEMENT PERFORMANCE REPORT \\ ENVIRONMENTAL RESTORATION \\ DECEMBER 2000}

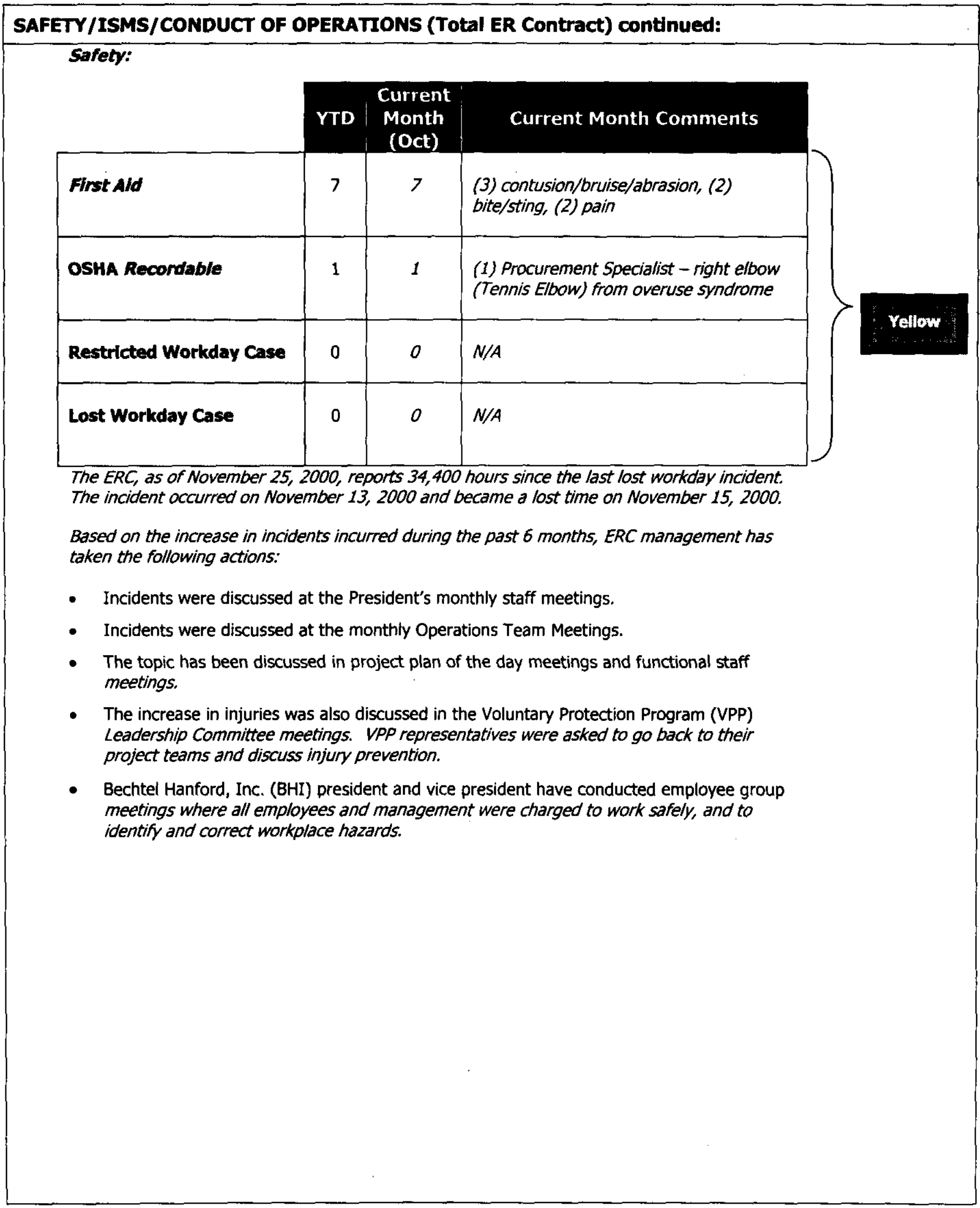




\section{ENVIRONMENTAL MANAGEMENT PERFORMANCE REPORT ENVIRONMENTAL RESTORATION \\ DECEMBER 2000}

\section{SAFETY/ISMS/CONDUCT OF OPERATIONS (Total ER Contract) continued: \\ ISMS: \\ DOE EM Performance Agreement: Maintain and improve the approved Integrated Safety \\ Management System (ISMS) - November 1, 2000 \\ Status: \\ - Conducted training for and initiated implementation of the new hazard evaluation process. \\ - Established Safety Performance Objectives/Measures for FY01. \\ - Held a kickoff meeting to define the process to be used to review, update, and submit for RL approval, safety performance objectives, performance measures, and commitments. \\ - Continued employee awareness of ISMS through the ISMS Question of the Day Program. \\ - Actively supporting the Hanford hosted DOE ISMS Workshop; participating in planning the workshop, coordinating breakout sessions, giving presentations, providing a poster display, and attending the workshop.}

\section{Conduct of Ops:}

ERC-CATS (Corrective Action Tracking System) Trend Data 11/1/99 through 10/31/00

\begin{tabular}{|c|c|c|c|c|c|c|c|c|c|c|c|c|}
\hline & Nov-29 & Dec-90 & Jan-00 & Feb-10 & Mardo0 & Apr $\rightarrow 0$ & May -00 & Jun- -0 & 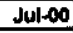 & Aut -00 & $\operatorname{sep}-\infty$ & Det $-\infty$ \\
\hline Lock \& Te? & 0 & 0 & 0 & 0 & 0 & 2 & 0 & 1 & 0 & 1 & 0 & 0 \\
\hline $\begin{array}{l}\text { Spills (Reportad on } \\
\text { Oceumence Reports) }\end{array}$ & 0 & 0 & 0 & 0 & 0 & 0 & 0 & 0 & 1 & 0 & 0 & 0 \\
\hline Procedure Vlolations & 2 & 6 & 3 & 1 & 1 & 2 & 2 & 1 & 0 & $* 1$ & $\cdot 9$ & D \\
\hline $\begin{array}{l}\text { Inadequetel Leck of } \\
\text { Procodure }\end{array}$ & 1 & 2 & 1 & 3 & 2 & 0 & 2 & 0 & 4 & $\oplus_{3}$ & 1 & 0 \\
\hline Mancoement Problem & 2 & 0 & 1 & 2 & 2 & 3 & 2 & 1 & 1 & 1 & $m+3$ & 1 \\
\hline
\end{tabular}

\begin{tabular}{|l|c|c|c|}
\hline Manceoment Probleme & 2 & & 0 \\
\hline
\end{tabular}

"* Trend data for one item not received until October.

***Trend data for two items not received until October

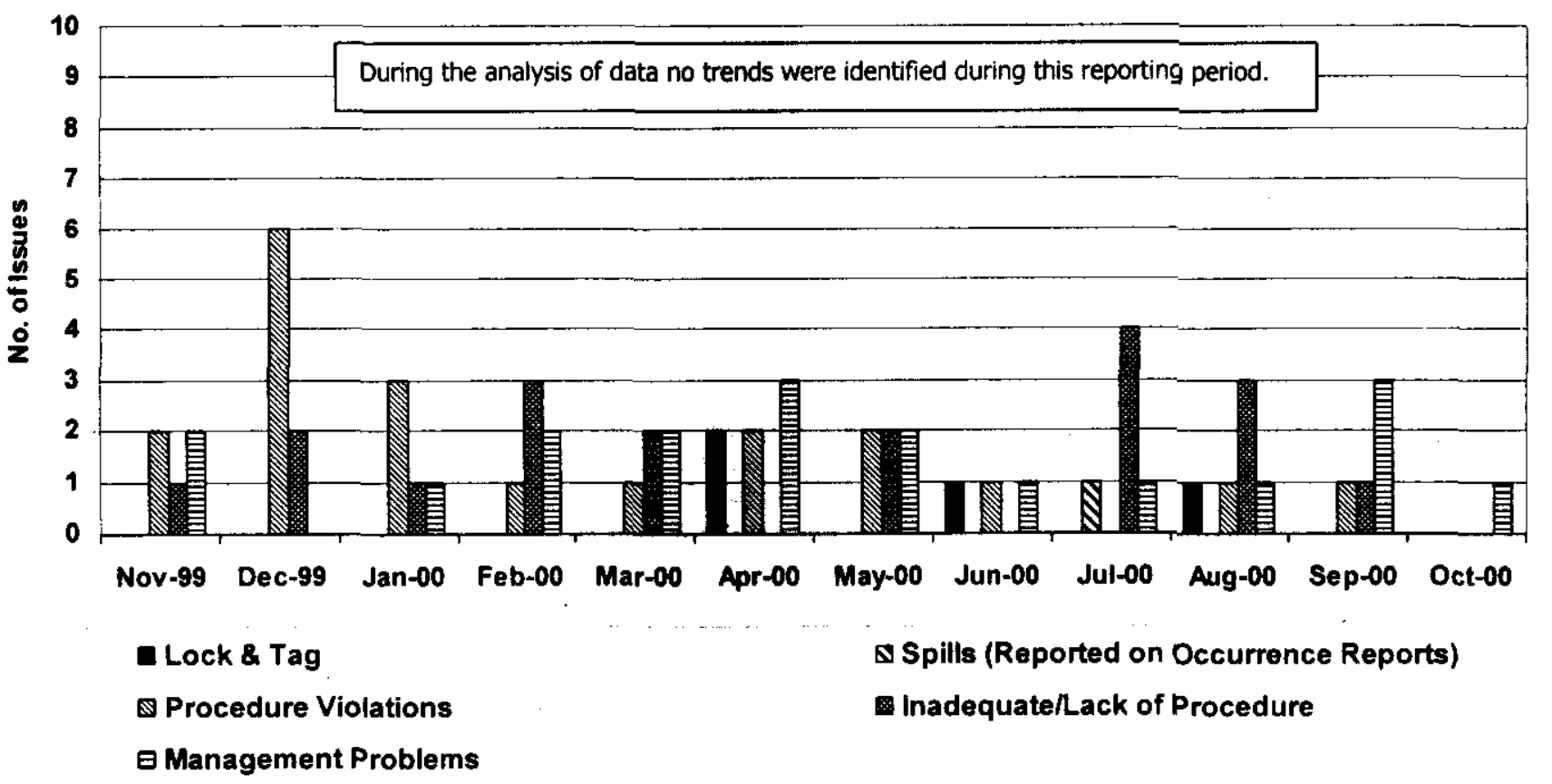

October Conduct of Ops Issues Continued on Next Page... 


\title{
ENVIRONMENTAL MANAGEMENT PERFORMANCE REPORT ENVIRONMENTAL RESTORATION \\ DECEMBER 2000
}

\section{SAFETY/ISMS/CONDUCT OF OPERATIONS (Total ER Contract) continued:}

\section{ectober conduct of Ons Issues:}

\author{
Management Issue: \\ Condition Description: On Friday, September 29, the Environmental Restoration Disposal \\ Facility (ERDF) received a tractor-trailer load of packaged duct from the 233-S project for \\ disposal in the ERDF. The trailer had been covered with plastic to prevent contamination of \\ the trailer bed. Since it was late in the day Friday, the load was staged in the Radiological \\ Material Area (RMA) for unloading at a later time.
}

On Tuesday, October 3, the packaged duct work was unloaded and placed in cell four at ERDF. The plastic was then removed from the trailer bed and placed alongside the duct for disposal. After the truck was brought back to the queue area, a Radiological Control Technician (RCT) performed a radiological survey to release the truck. During the survey a "hot spot" was found on the trailer. The hot spot is approximately six inches in diameter and had the following readings:

- $20,000 \mathrm{DPM} / 100 \mathrm{~cm}$ total alpha

- $1,035 \mathrm{DPM} / 100 \mathrm{~cm}$ removable alpha

- 75,000 DPM/100cm total beta/gamma

- less than $1,000 \mathrm{DPM} / 100 \mathrm{~cm}$ removable beta/gamma

The information reported exceeds reporting requirements, thus an off-normal was categorized (10.3.b).

Corrective Action Plan: In the future, shipments of plastic wrapped waste containing removable contamination and shipped on open trailers, will be scheduled for disposal as soon as practical upon arrival at ERDF. If the waste must be staged on a trailer prior to disposal (at ERDF or at the point of origin) for a period of time when inclement weather is forecast, then the load will be covered with waterproof tarps. This new practice will be discussed with ERDF personnel who process Waste Shipping and Receiving Plans and discussed with all ERDF Operations personnel at a future Plan of the Day (POD) meeting.

\section{Previous Conduct of Ops Issues Not Received Until October:}

\section{Management Issue:}

Condition Description: Although site specific training is provided to facility personnel, portions of the site specific training required under the 100-NR Closure Plan were not documented, and a record of the training of at least one individual was not available in the operating record or through the Bechtel Hanford, InC. (BHI) Training Organization.

Corrective Action Plan: Training has been provided and documented for applicable $E R C$ and Subcontractor facility personnel. The training is documented under ERC Course Number 105653. ERC Training Records maintain records of training for ERC personnel. Training of the Subcontractor facility personnel are maintained by the Subcontractor with a copy held by the NR-1 Administrative Assistant. Follow-up and assurance of training completion for this and other site-related training is now conducted by the assigned Project Administrative Assistant. The Subcontractor has been directed to provide evidence of training for newly assigned personnel. 


\section{ENVIRONMENTAL MANAGEMENT PERFORMANCE REPORT ENVIRONMENTAL RESTORATION \\ DECEMBER 2000}

\section{SAFETY/ISMS/CONDUCT OF OPERATIONS (TOtal ER Contract) continued:}

Condition Description: The Closure Plan Section A2.0 "Unit Description", Subsection A2.1.10 "Security" states that a "chained link rence" with "locked gate access" is used to preclude "unknowing entry". Also posted at the unit are placards that read "Danger Unauthorized Personnel Keep Out". Approximately 150 feet of fence, the gate, and several signs have been removed from the perimeter of the unit without modification to the Closure Plan.

Corrective Action Plan: The Site Closure Plan has been revised to allow for removing the perimeter fence (ref. DOE/RL-2000-16, Revision 3.0, Subsection 3.1.1.2). Signs have been re-posted on the excavation sign boundaries. The NR-1 Team has reviewed and revised, as necessary, the requirements of the Site Closure Plan. All assigned persons are now aware of the Plan and the need for change to the plan prior to implementing it.

\section{Procedure Problem:}

Condition Description: During a DOE Heat Stress Assessment, the DOE Assessor observed a noteworthy condition that could cause a potential safety concern, although it appears did not violate any specific requirement. On $7 / 19 / 00$, a D\&D Worker was tasked as a fire watch for a cutting operation. The worker performing the cutting and the fire watch were both in a $J L G$ lift approximately 45 feet in the air performing the task at $F$ Reactor. The fire watch was standing at one end of the JLG platform and the worker conducting the cutting was at the far end of the platform. The platform is 8 feet wide. The worker performing the cutting was wearing fire retardant anti-contamination clothing Personal Protective Equipment (PPE) as specified in the hot work permit and referenced in the Health and Safety Plan (HASP). The fire watch was wearing ordinary anti-contamination PPE. The hot work procedures requires the employees to wear appropriate PPE. For personnel conducting hot work in a radiological area, red flame resistant anti-CS are required. All other personnel are required to have appropriate PPE based on requirements stated in the job Activity Hazard Analysis or the HASP. It was determined that the worker performing the cutting would be involved in hotwork thus would wear fire retardant PPE. The fire watch would be at a safe distance from the slag and sparks and not involved in hotwork, thus the appropriate PPE would be normal anti-contamination PPE. Although the two workers were in close proximity and the platform was somewhat confined, the fire watch was not affected by the cutting operation (i.e., hot slag and sparks). Part of this determination was made due to the ambient outside temperatures during this time, which ranged from the high 90's to low 100's. After deliberation, Project Management determined to categorize this incident as an off-normal (10 C.3.b), to ensure analysis of this type of work and condition could be conducted, and an evaluation of documents such as procedures and HASPs to ensure ambiguity in documents do not pose future safety concerns.

Corrective Action Plan: (1) Revise BHI-SH-02, Procedure 6.4.3 to include a statement such as: "when conducting hot work from a manlift, $J L G$, etc. personnel in the basket should be trained as a fire watch and are required to wear PPEs as designated on the Hotwork Permit as determined by the job supervisor". (2) Revise Procedure BHI-SH-02, 6.4.3 to specifically state: "it is the responsibility of the job supervisor, after conferring with the Radiological Engineer and Safety Engineer, to specify the selection of PPE to be worn for each specific task. (3) Revise the Hotwork Permit form to include a check-off for PPE requirements. (4) Disseminate and/or review the policy changes as stated in actions 1 and 2, and the revised form in action 3, to, or with the appropriate personnel to ensure a clear understanding of the expectations outlined in the revisions made. The target date to complete these actions is December 28. 


\section{ENVIRONMENTAL MANAGEMENT PERFORMANCE REPORT ENVIRONMENTAL RESTORATION \\ DECEMBER 2000}

SAFETY/ISMS/CONDUCT OF OPERATIONS (Total ER Contract) continued:
Procedure Violation:
Condition Description: The process to prepare nonconformance reports was deficient for
two items of measuring and testing equipment (M\&TE). (1) The calibration seal placed by
the subcontracted calibration lab on the Druck Pressure Indicator (702-35-40-014) was
broken. The seal indicated that the calibration was void if the seal was broken. The unit was
calibrated on $12 / 21 / 99$ and was used on $7 / 12 / 00,6 / 15 / 00$, and $6 / 14 / 00$. The equipment
record for the unit was annotated that the on/off switch was changed on $6 / 13 / 00$ requiring
the unit to be opened and the seal broken. (2) Documentation was not available that the
initial calibration data was received from the manufacturer for the new/y purchased digital
calipers from L.S. Starrett (702-I 5-06-002). The only documentation supplied was an
inspection certificate and equipment specification.
Corrective Action Plan: (1) The Druck Pressure calibrator mechanical on/off switch
was repaired by a trained and qualified Instrument Technician with the approval of
the M\&TE Coordinator. The repair had no effect on the instruments' calibration
integrity per written response from Belhaven. (2) The Starrett Model 721 digital
calipers were removed from service, sent to Belhaven Applied Technologies and
verified to be in calibration. (3) Revise BHI-FS-01 Procedure 3.15 to address minor
repairs ie. switched, frayed probes, battery changes, etc. (4) All new equipment
ordered will be sent out to the calibration prior to use or that when purchasing new
equipment the vendor will be qualified and proper calibration test reports and
certificates will be obtained.

REGULATORY/EXTERNAL/DOE-RL \& HQ ISSUES AND REQUESTS:

Refer to individual Project issues in the following Section B and Section C. 


\section{ENVIRONMENTAL MANAGEMENT PERFORMANCE REPORT ENVIRONMENTAL RESTORATION DECEMBER 2000}

\section{TOTAL COST/SCHEDULE OVERVIEW (Total ER Contract):}
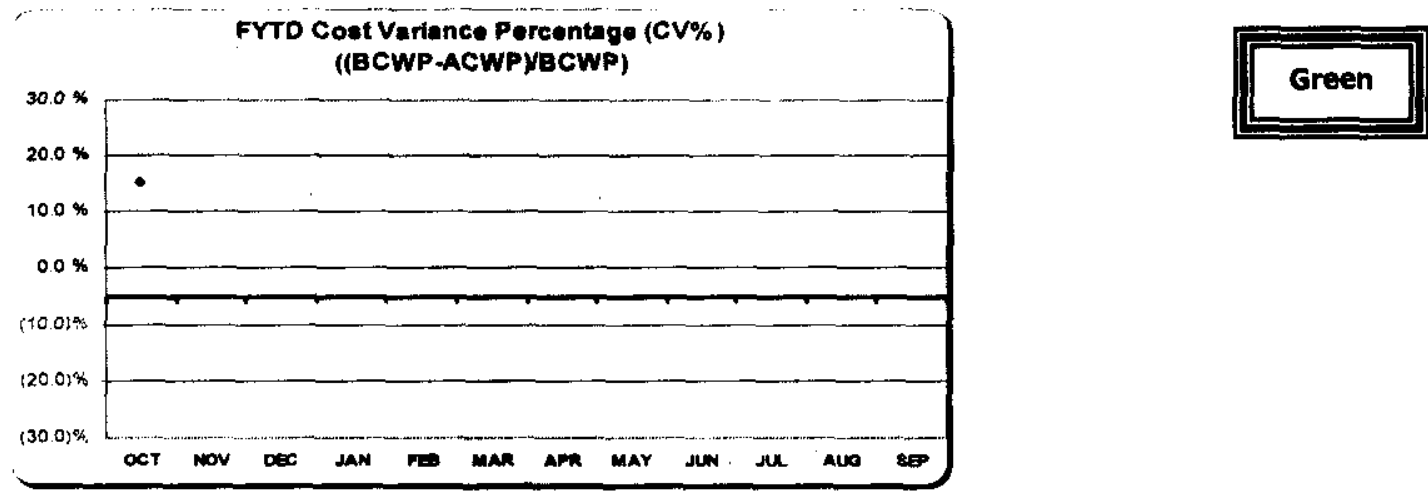

Desired performance is better than $-5.0 \%$.

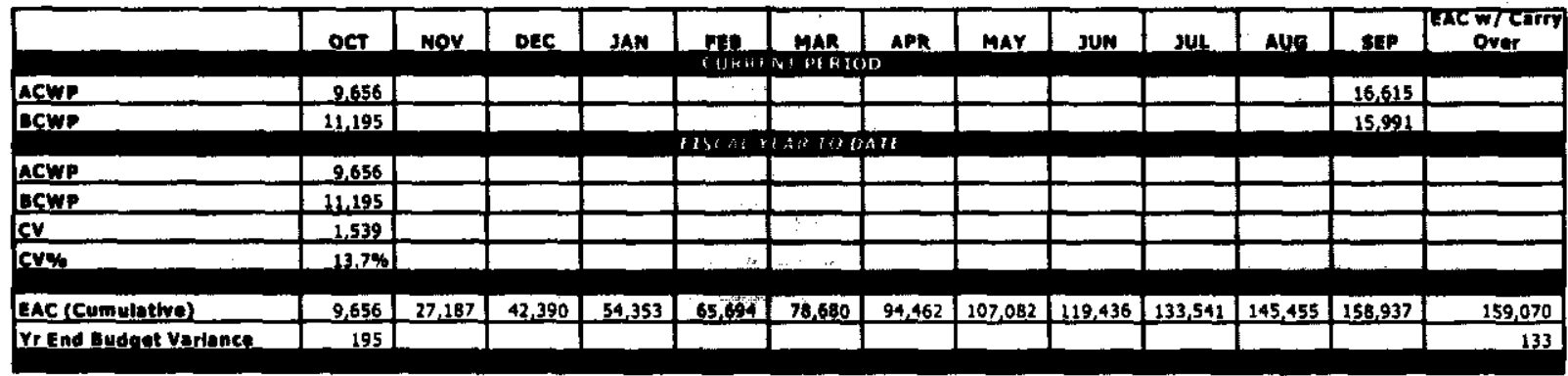

For variance explanation by PBS, see Project Status Section of each project.
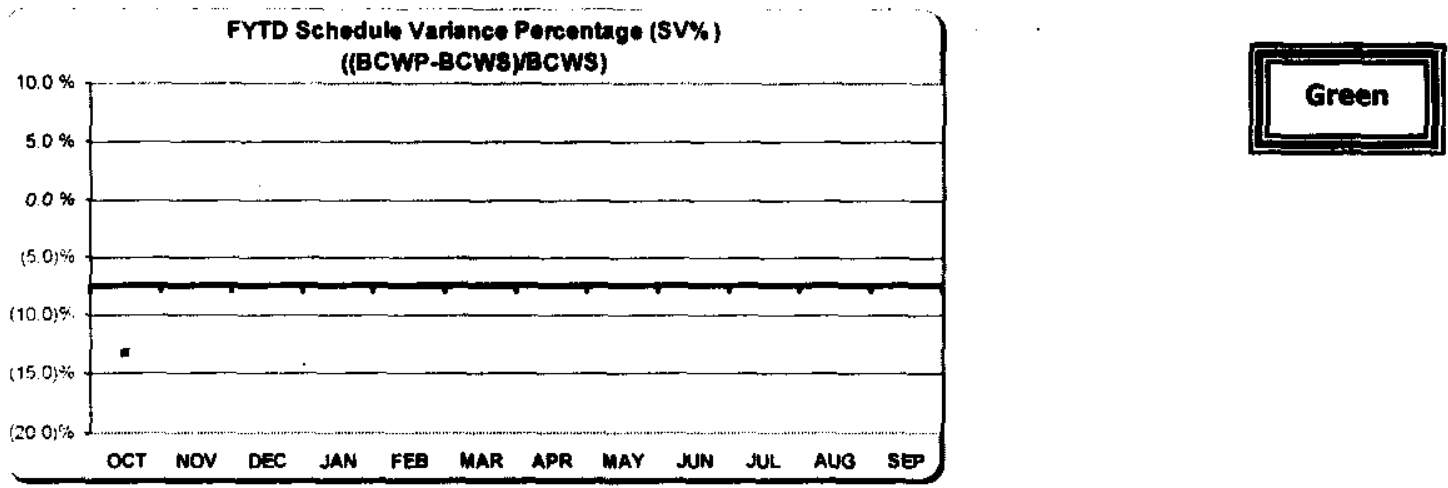

Desired performance is better than $-7.5 \%$.

\begin{tabular}{|c|c|c|c|c|c|c|c|c|c|c|c|c|}
\hline & ocr & & & & & & APR & MAY & JUN & SHL & AUG & SEP \\
\hline DWP & 16.110 & 10.286 & 13,233 & $10,2 \%$ & 10,051 & 11.813 & 24,703 & 11,619 & 11.559 & 13,381 & 11.497 & 13,404 \\
\hline DWE (Accum) & 11,110 & 21,396 & 33.629 & 43.91 & 53,948 & 65.781 & 80,484 & 92,103 & 103,662 & 217,043 & 2128.540 & 141,944 \\
\hline$\frac{\text { Ecws }}{\text { Scwp }}$ & $\frac{12,782}{11,195}$ & 12,434 & 25.342 & & 11368 & 13,567 & 16,480 & 12,698 & השות & 14,638 & 13.370 & 13.962 \\
\hline ecws & 12,782 & 25,216 & 40,563 & 51,740 & 63.108 & 76,675 & 23.155 & 105.853 & 118,295 & 132.933 & 145.303 & 159.264 \\
\hline Bcwe & 11,195 & & & & & & & & & & & \\
\hline sy & $(1,587)$ & & & & & & & & & & & \\
\hline $5 \times \%$ & $-12.4 \%$ & & & & & & & & & & & \\
\hline
\end{tabular}

For variance explanation by PBS, see Project Status Section of each project. 


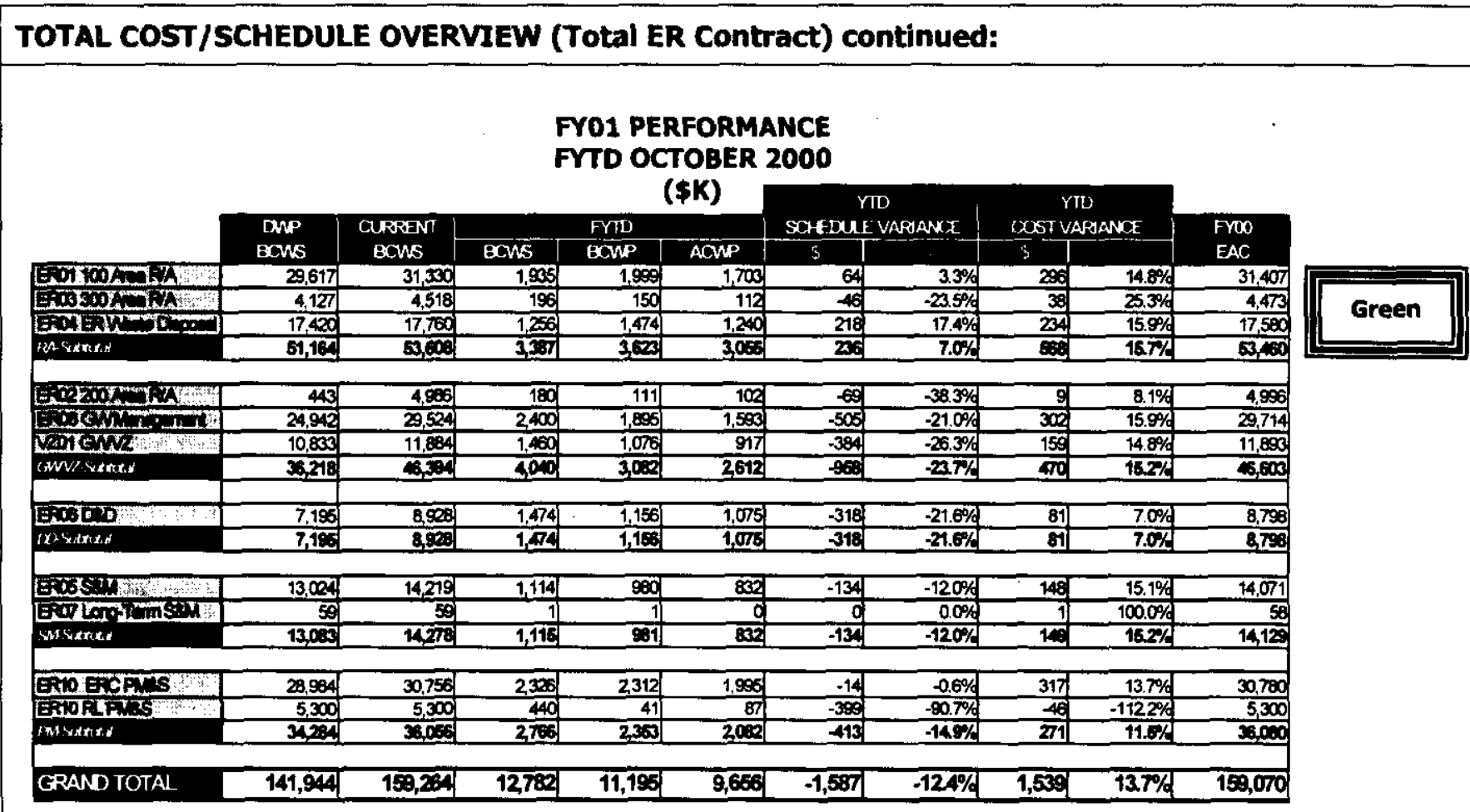

\section{Cost/Schedule Status:}

\section{Cost Variance Summary}

At the end of October, the ER Project had performed $\$ 11.2 \mathrm{M}$ worth of work, at a cost of $\$ 9.7 M$. This results in a favorable cost variance of $\$ 1.5 M(+13.7 \%)$. The positive cost variance is attributed to less labor required to complete remediation Closeout Verification Packages (CVPS) due to use of a streamlined format and consolidation of waste sites; future EROF overtime hours that will be used in third and fourth quarters were level loaded throughout the fiscal year; groundwater monitoring and vadose zone accruals experienced processing delay; less labor required for chemical treatment of two groundwater monitoring systems; radiation survey costs were less than planned for REDOX and U Plant; and program management year-end accrual reversals were not reaccrued in October.

\section{Schedule Variance Summary}

Through October, the ER Project is $\$ 1.6 \mathrm{M}(-12.4 \%)$ behind schedule. The negative schedule variance is attributed to unplanned sharing of RCRA well drilling crews to support 618-11 Burial Ground tritium investigation; addition of new tritium investigation activities; groundwater modeling and monitoring activities delayed while completing fYOO carryover higher-priority work; GW/VZ Characterization of Systems scope experienced late start due to resources working other project activities and delay in obtaining subcontractor, and GWNZ Science and Technology activities delayed due to resources working on FYOO carryover work, as well as contractor delays in distribution of contaminated samples; $D$ and $H$ Reactor ISS work delayed due to awaiting approval for removal action work plans, safety evaluation report, and various work packages; $F$ Reactor backfill delayed due to awaiting analysis results; replanning required for $F$ Reactor water removal system; and late billing of site-wide assessments. 


\section{ENVIRONMENTAL MANAGEMENT PERFORMANCE REPORT ENVIRONMENTAL RESTORATION \\ DECEMBER 2000}

\section{PERFORMANCE OBJECTIVES:}

Refer to individual Project issues in the following Section B and Section C.

\section{KEY INTEGRATION ACTIVITIES:}

\section{RTVER CORRIDOR:}

A Memorandum of Understanding (MOU) was signed with Energy Northwest for transportation and disposal of Hanford Generating Plant wastes. Energy Northwest will begin dismantlement of the Hanford Generating Plant in January with removal of the pipe trestle that connects the plant with the $100 \mathrm{~N}$ Reactor complex. The overall dismantling project is expected to take two years to complete. All materials that are radiologically contaminated will be sent to ERDF for disposal.

Bechtel-Hanford, Inc. (BHI) closed a significant RL action item in October with implementation of an Employee Job Task Analysis (ETTA) program for subcontractors. BHI, along with Pacific Northwest Nationa/ Laboratory (PNNL) and Fluor Hanford (FH), spent two years in developing a site-wide program to assess hazards and perform medical monitoring for subcontractor personnel who might be at risk of potential exposure. The primary implementation tool for the Hanford contractors involves incorporation of specific contract language and partnering with the subcontractor to ensure employees who are at risk of exposure are captured in the ETTA database.

In October, a joint BHI, FH, and PNNL team conducted a "Hanford Analytical Services" presentation at the National Sample Management Organization Workshop at Oak Ridge National Laboratory. Hanford Analytical Services is a joint RL, BHI, FH, and PNNL board that coordinates laboratory services for the Hanford Site. HQ representatives complimented the team on their presentation and stated that the Hanford Analytical Services board provides a good model for other DOE sites.

\section{CENTRAL PLATEAU:}

ER continues to work closely with the River Protection Project (RPP) on vadose zone project plans and issues. RPP project manager presents related GW/NZ status to ER management at monthly ER project reviews.

\section{UPCOMING PLANNED KEY EVENTS:}

Tri-Party Agreement Milestone M-13-25, Submit Uranium Rich Process Waste Group (200-PW2) Work Plan, due $12 / 31 / 00$.

Tri-Party Agreement Milestone M-13-00K, Submit 1200 NPL RI/FS (RFI/CMS) Work Plan, due $12 / 31 / 00$.

Tri-Party Agreement Milestone M-16-27A, Complete 100-HR-3 Phase I, ISRM Barrier Emplacement, due 12/31/00.

Tri-Party Agreement Milestone M-24-47, Install 4 Additional Wells at SST WMA T, due $12 / 31 / 00$.

Tri-Party Agreement Milestone M-24-48, Install 4 Additional Wells at SST WMA TX-TY, due $12 / 31 / 00$.

Tri-Party Agreement Milestone M-24-00L, Install RCRA Groundwater Monitoring Wells Up to 50 in $\operatorname{cr} 2000$, due $12 / 31 / 00$.

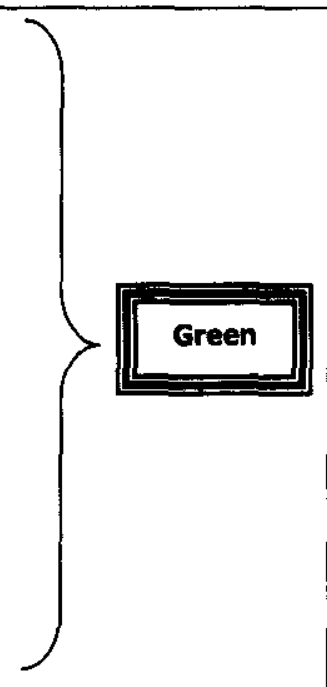




\section{Richland Operations Office Environmental Restoration \\ Environmental Management Performance Report}

\section{Section B - River Corriderlntioluleitioll}

\section{December 2000}

- Remedial Action and Waste Disposal Project
- Decommissioning Projects (Interim Safe Storage and 233-S)

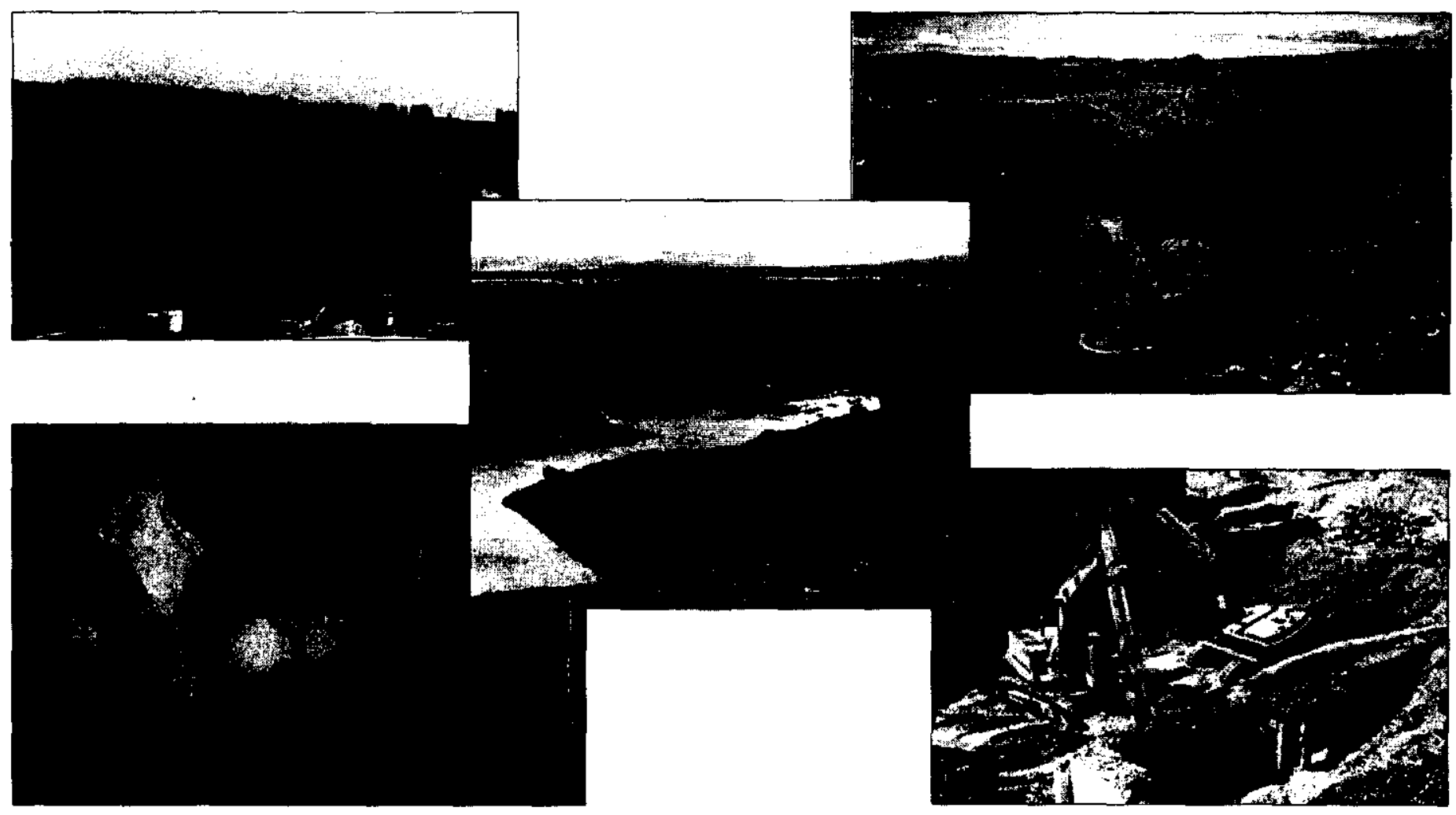

Focused on Progress...

Focused on Outcomes!

Department of Energy

Richland Operations Office
- Program Management and Support 


\section{ENVIRONMENTAL MANAGEMENT PERFORMANCE REPORT ENVIRONMENTAL RESTORATION \\ DECEMBER 2000}

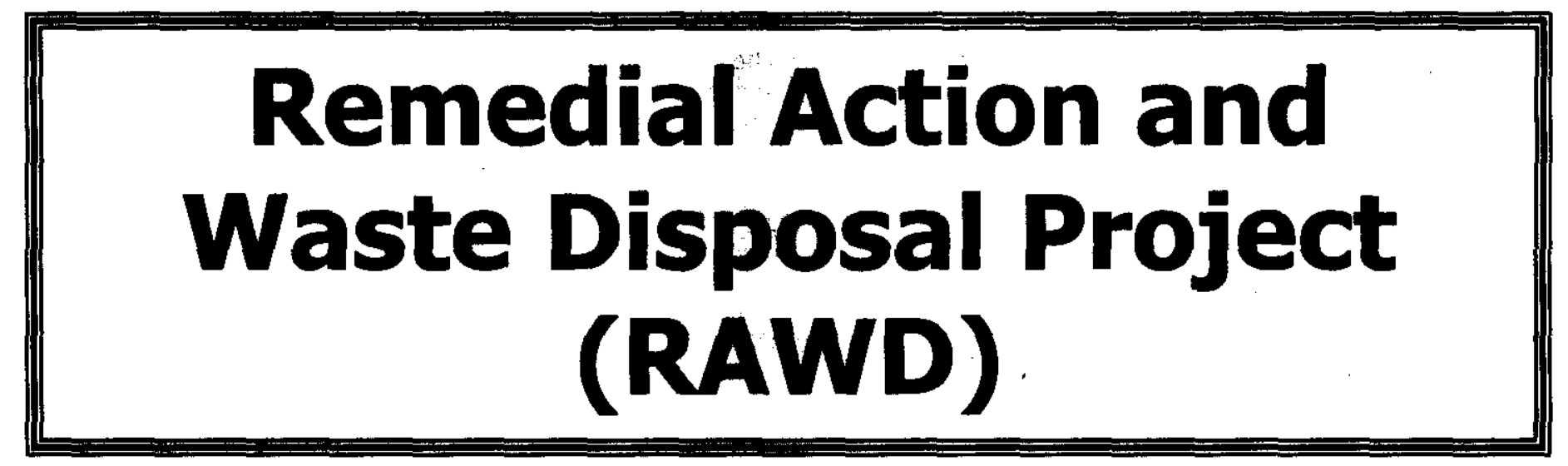




\title{
ENVIRONMENTAL MANAGEMENT PERFORMANCE REPORT ENVIRONMENTAL RESTORATION \\ DECEMBER 2000
}

\section{SECTION B - RESTORING THE RIVER CORRIDOR}

\author{
Financial / Performance Measures data as of month-end October. \\ All other data as of November 30, 2000 (unless otherwise noted). \\ Remedial Action \& Waste Disposal Project (RAWD):
}

ACCOMPLISHMENTS: RAWD

Environmental Restoration Disposal Facility (ERDF) Transportation and Operations: Hydroseeding was completed over the interim cover of ERDF Cells \#1 and \#2 during October. These two cells were filled with waste from ER remediation activities between mid-FY96 and mid-FYOO.

During October, shipments totaling 34,385 metric tons (37,903 tons) of contaminated waste were transported to the ERDF. This is slightly ahead of planned quantities. To date, $2,341,146$ metric tons $(2,580,685$ tons) of material have been received and placed in the disposal facility.

$100 \mathrm{~B} / \mathrm{C}$ Area Remediation: Six bids were received for the remediation of the $100 \mathrm{~B} / \mathrm{C}$ Area pipelines on September 29. Clarification questions were sent to each bidder on October 13. Responses to clarification questions were received on October 18. Final bidder evaluation was completed on October 30, and the contract was awarded on November 28.

100 D Area Remediation: Analysis of closeout sampling results and preparation of Closeout Verification Packages (CVPs) progressed for 100 D Area remediated waste sites. During October, five CVPs were transmitted to the regulators. Laboratory results indicated that chromium +6 levels in the $100 \mathrm{D}$ Area were below the cleanup level established in the $K d$ study. The regulators agreed to proceed with backfill concurrence and closeout. The subcontractor is scheduled to return in mid-December to complete the backfill of the remaining sites.

100 F Area Remediation: Excavation and removal were completed for the 1.5-meter (60inch) diameter steel pipeline and the 1.8-meter (72-inch) diameter reinforced concrete pipeline between the retention basin and the outfall structure in the $100 \mathrm{~F}$ Area. Overburden removal was completed and removal started for the 1.1-meter (42-inch) diameter reinforced concrete pipeline between the reactor building and the retention basin.

A baseline change proposal ( $B C P$ ) was submitted for the excavation of 7,257 metric tons (8,000 tons) of additional waste at the north and south segments of the 100-F-19 effluent underground pipelines.

$100 \mathrm{H}$ Area Remediation: Baseline excavation activities were completed in the $100 \mathrm{H}$ Area in August; however, plumes were encountered during verification sampling. A BCP was submitted for the excavation of 6,804 metric tons (7,500 tons) of additional waste at 100-H-24 substation (PCBs), 116-H-7 retention basin (PCBs) and 100-H-21 pipelines (lead). Performing up to three potholes in the 116-H-7 retention basin was also accomplished in an attempt to identify the extent of the chromium +6 contamination.

Analysis of closeout sampling results and preparation of CVPs for the $100 \mathrm{H}$ Area Operable Unit are progressing.

A BCP was submitted for implementation of the Supplemental Environmental Project (SEP) "Radiological Survey and Release of 100 H Reactor Lead Bricks for Reuse." This is part of the Multi Media Inspection Consent Agreement Final Order.

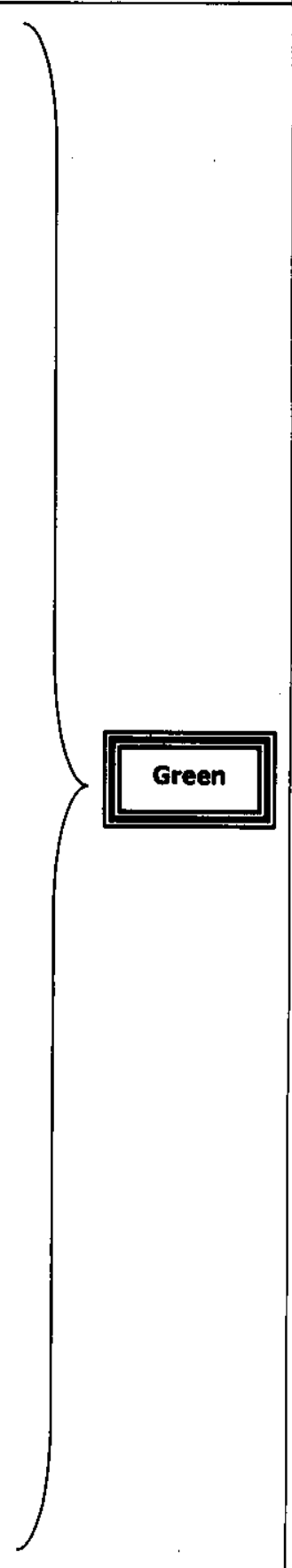




\title{
ENVIRONMENTAL MANAGEMENT PERFORMANCE REPORT ENVIRONMENTAL RESTORATION \\ DECEMBER 2000
}

\begin{abstract}
ACCOMPLISHMENTS continued: RAWD
100 N Area Remediation: Saw cutting activities on the 116-N-3 crib cover panel joints were performed in preparation for removal of the cover asnels. A 181-metric ton (200-ton) crane was mobilized on site that is being used to individually lift the 420 panels. Each panel measures approximately 1.2 meters by 10.7 meters ( 4 feet by 35 feet) and weighs between 3 to 4 metric tons (7,000 to 9,000 pounds). Extensive planning, including a dry run and readiness evaluation, was performed prior to lifting the first crib cover panel on October 30.

During October, walkdown activities were performed to identify 100-NR-1 source sites not requiring decontamination and decommissioning of buildings prior to remediation.

100/300 Area Assessments: Kickoff meetings were held to initiate the 100/300 Area design/assessment scope.

300 Area Remediation: The ERC commercial analysis of the 618-4 Burial Ground drummed waste treatment was completed and a recommendation was forwarded to for their concurrence.

300/600 Area Remediation: The design process continues for the J.A. Jones and 600-23 waste sites in support of the Columbia River Corridor Initiative. The design was submitted for review, and comments were received and are being incorporated. Design quantities were significantly increased at both waste sites based on the remedial design ground penetrating radar (GPR) and electromagnetic induction (EMI) geophysical surveys. Bids were requested for the J.A. Jones 1 and 600-23 sites on November 16, and are due on November 30. Site walkdowns were conducted on November 20.
\end{abstract}

\section{SAFETY/ISMS/CONDUCT OF OPERATIONS: RAWD}

See Executive Summary.

\section{BREAKTHROUGHS/OPPORTUNITIES FOR IMPROVEMENT: RAWD}

Remote Panel Removal: Due to Radiological concerns regarding demolition of the 116-N-3 Crib, the Remediation Subcontractor (Foster Wheeler) designed a "slide-on" clamp to be used with a crane to remotely lift the crib cover panels and place them in a size reduction area for processing. The original plan required laborers to walk on the crib for each lift to handle "tag" lines necessary for controlling the clamps. The Lampson crane engineer recommended the placement of "tag" lines rigged to the crane and controlled by the crane operator, thus eliminating the need for laborers to walk on the crib. This recommendation has resulted in a $100 \%$ remote panel removal operation and a significant reduction in personnel exposure.

\section{LONG-TERM (6 MONTHS PLUS) IMPORTANT ITEMS: RAWD}

\author{
None identified at this time.
}

MAJOR COMMITMENTS (FISCAL YEAR PLUS 6 MONTHS): RAWD

- DOE Secretarial:

None identified at this time.

- DOE EM Performance Agreement:

None identified at this time. 


\section{ENVIRONMENTAL MANAGEMENT PERFORMANCE REPORT \\ ENVIRONMENTAL RESTORATION \\ DECEMBER 2000}

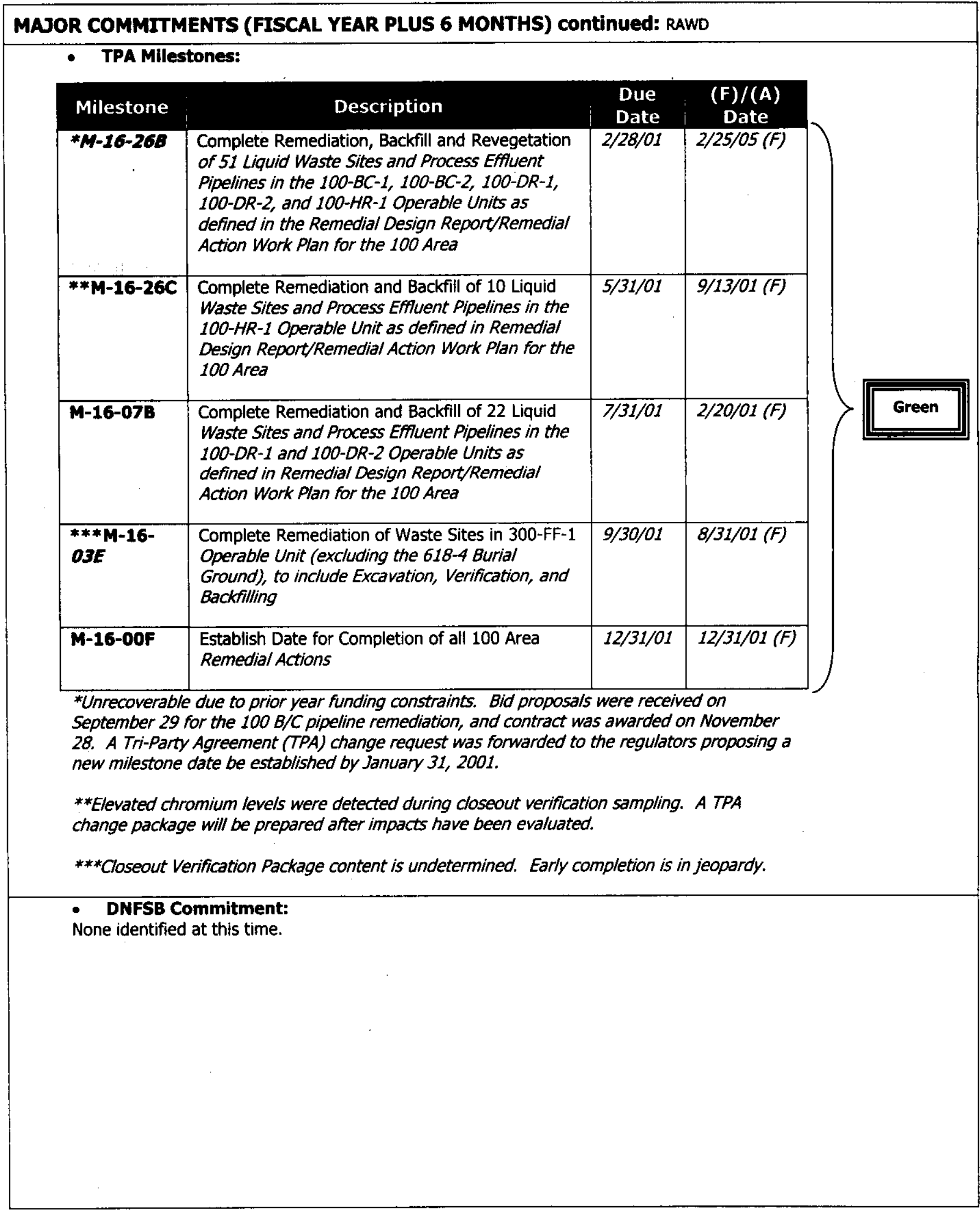




\section{ENVIRONMENTAL MANAGEMENT PERFORMANCE REPORT \\ ENVIRONMENTAL RESTORATION \\ DECEMBER 2000}

\section{PERFORMANCE OBJECTIVES: RAWD}

\begin{tabular}{|c|c|c|c|c|}
\hline PI & $\begin{array}{l}\text { Less } 10^{\circ} \% \text { fur } \\
\text { Comprehensive }\end{array}$ & $\begin{array}{c}\text { Pi } \\
\text { Allocition: } \\
\text { of Fee }\end{array}$ & Task & Status \\
\hline RAWD & $70 \%$ & $\begin{array}{l}80 \% \\
10 \% \\
10 \%\end{array}$ & $\begin{array}{l}490,000 \text { Tons by } \\
9 / 30 / 01 \\
\text { Backfill } 16 \text { Sites by } \\
9 / 30 / 01 \\
\text { 50,000 Additional } \\
\text { Tons by } 9 / 30 / 01 \\
\text { (*Stretch) } \\
\text { CV <5.0\%; SV <7.5\% } \\
\text { for grouped PBS ER01, } \\
\text { ERO3, ERO4 }\end{array}$ & $\begin{array}{l}\text { On schedule. } \\
\text { On schedule. } \\
\text { None } \\
\text { commenced as } \\
\text { of } 10 / 31 / 00 .\end{array}$ \\
\hline
\end{tabular}

PERFORMANCE MEASURES/METRICS: RAWD - (RWver and Plateau)

\begin{tabular}{|l|c|c|c|c|c|}
\hline & $\begin{array}{l}\text { DWP } \\
\text { FY01 }\end{array}$ & $\begin{array}{c}\text { Fro1Mgmt } \\
\text { Commitments }\end{array}$ & $\begin{array}{c}\text { Faseline } \\
\text { hanges) }\end{array}$ & $\begin{array}{c}\text { Forecast } \\
\text { For } \\
\text { FY01 }\end{array}$ & $\begin{array}{c}\text { Completed } \\
\text { VTD }\end{array}$ \\
\hline $\begin{array}{l}\text { Waste Sttes } \\
\text { Excavated }\end{array}$ & 12 & 12 & 14 & 14 & 0 \\
\hline
\end{tabular}
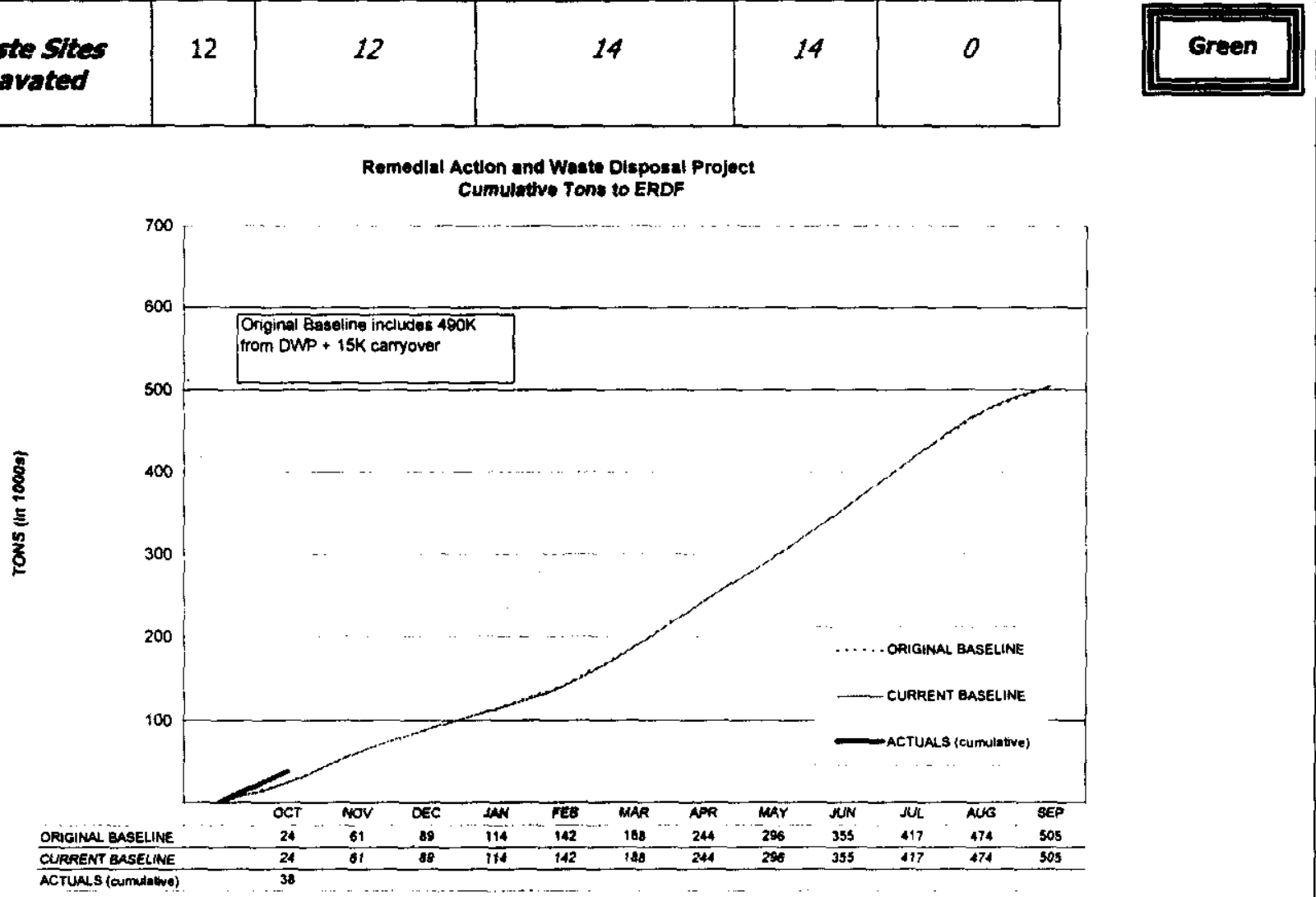


\section{ENVIRONMENTAL MANAGEMENT PERFORMANCE REPORT ENVIRONMENTAL RESTORATION \\ DECEMBER 2000}

\section{STRETCH AND SUPERSTRETCH GOALS: RAWD}

\begin{tabular}{|r|r|r|}
\hline \multicolumn{1}{|c|}{ FYO1 RAWD "Stretch" Goals } & $\begin{array}{r}\text { Estimated } \\
\text { Tons (K) }\end{array}$ & \multicolumn{1}{|c|}{$\begin{array}{c}\text { Approved } \\
\text { Tons (K) }\end{array}$} \\
\hline $\begin{array}{l}\text { Remediate Additional 50K Tons of Contaminated Soll } \\
\text { by 9/30/01 } \\
\text { (1) Additional Contamination Soll at 100-F Pipelines } \\
\text { (2) Additional Contamination Material at 100-H Sites }\end{array}$ & $50 \mathrm{~K}$ & \\
\hline S/Total Remedial Action Stretch Goals: & & $\begin{array}{r}7,500 \mathrm{~K} \\
8,000 \mathrm{~K}\end{array}$ \\
\hline
\end{tabular}

\section{PROJECT STATUS (COST/SCHEDULE/MAJOR BASELINE CHANGE: RAWD}

- Schedule:

\begin{tabular}{|c|c|c|c|c|}
\hline \multirow{2}{*}{ Remedial Action \& Waste Disposal Project } & BCWS & BCWP & Variance & \\
\hline & $\$ \mathbf{K}$ & $\$ \mathbf{K}$ & $\mathbf{\$ K}$ & \\
\hline 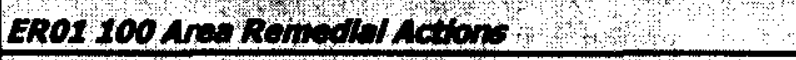 & 1,935 & 1,999 & 64 & \\
\hline 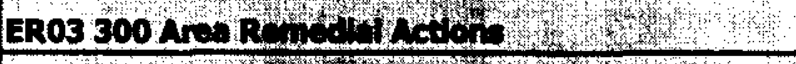 & 196 & 150 & -46 & \\
\hline 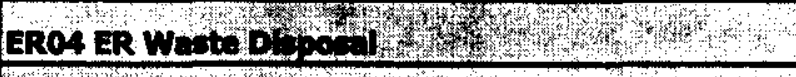 & 1,256 & 1,474 & 218 & Green \\
\hline S. TOTAL Remodial Actions & 3,387 & 3,623 & 236 & \\
\hline
\end{tabular}

\section{PBS-ERO1 - 100 Area Remedial Action}

Schedule Variance $=+\$ 64 K ; 3.3 \%$

Cause: The positive schedule variance is due to less sharing of resources between waste sites and greater than anticipated production rates.

Resolution: A BCP is being prepared to reflect actual work sequencing and production rates; continuation of these production and labor trends will provide opportunities to accomplish additional stretch and other "emerging" work.

Cause: Slower progress than originally planned at the $100-$ NR-1 remediation site due to complexities in the performance of the work scope.

Resolution: Schedule recovery can be achieved by increasing the maximum number of containers allowed to be shipped to ERDF by the Subcontractor during excavation of the 116-N-3 Crib.

\section{PBS-ER03 - 300 Area Remedial Action}

Schedule Variance $=(\$ 46 K) ;(23.5 \%)$

Cause: Issues with the 300-FF-1 CVP and delays in water system installation.

Resolution: Discussions with the regulators on the CVP have been initiated. Phase II of the waterline tie-in has been scheduled with the subcontractor for early November. 


\section{ENVIRONMENTAL MANAGEMENT PERFORMANCE REPORT ENVIRONMENTAL RESTORATION}

DECEMBER 2000

\begin{tabular}{|c|c|c|c|c|}
\hline \multicolumn{5}{|c|}{ PROJECT STATUS (COST/SCHEDULE/MAJOR BASELINE CHANGE continUEd: RAWD } \\
\hline \multicolumn{5}{|c|}{$\begin{array}{l}\text { PBS-ER04 - Environmental Restoration Waste Disposal } \\
\text { Schedule Variance }=\$ 218 \mathrm{1} ; \mathrm{4} \% \\
\text { Cause: Reflects waste disposal and transportation efficiencies due to increased waste } \\
\text { volumes from } 100 \text { Area Remediation sites. }\end{array}$} \\
\hline \multicolumn{5}{|l|}{ - Cont: } \\
\hline & MP & ACWP & Valiance & \\
\hline & $\$ K$ & $\$ K$ & $\$ \mathrm{~K}$ & \\
\hline 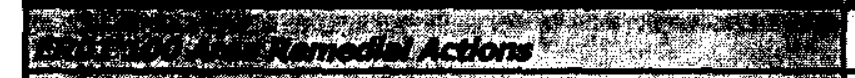 & 1,999 & 1,703 & 296 & \\
\hline 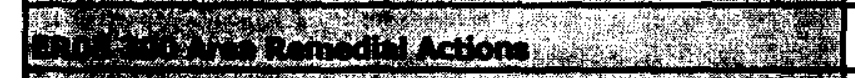 & 150 & 112 & 38 & Green \\
\hline Wu, & 1,474 & 1,240 & 234 & \\
\hline 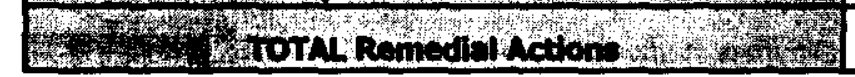 & 3,623 & 3,055 & 568 & \\
\hline
\end{tabular}

PQS-EROL - 100 Area Remedial Action

Cost Variance $=\$ 296 \mathrm{~K} ; \mathbf{1 4 . 8 \%}$

Cause: Less labor was required than anticipated to prepare CVPs due to the use of a "streamlined" format and the consolidation of waste sites.

Resolution: Incorporated in EAC. Underrun will be used to perform additional remediation work.

PBS-ER03 - 300 Area Remedial Action

Cost Variance $=\mathbf{\$ 3 8 K} ; \mathbf{2 5 . 3 \%}$

N/A

PBS-ER04 - Environmental Restoration Waste Disposal

Cost Variance $=\mathbf{\$ 2 3 4 K} ; \mathbf{1 5 . 9 \%}$

Cause: Overtime hours that will be used in third and fourth quarters were level loaded thoughout the fiscal year; performed additional soil quantities resulting in a lower unit cost.

Resolution: EAC loading of overtime hours corrected; EAC reduced by the man hours saved. 


\section{ENVIRONMENTAL MANAGEMENT PERFORMANCE REPORT ENVIRONMENTAL RESTORATION \\ DECEMBER 2000}

\section{REGULATORY ISSUES: RAWD}

Tri-Party Agreement Milestone M-16-26B: M-16-26B, "Complete Remediation, Backfill, and Revegetation of 51 Liquid Waste Sites and Process Effluent Pipelines in the B/C, DR, and HR Operable Units" by February 28, will be missed due to lack of funding in FY99 and FYOO for $100 \mathrm{~B} / \mathrm{C}$ pipeline remediation activities.

Status: Bid proposals were received on September 29 for the $100 \mathrm{~B} / \mathrm{C}$ pipeline remediation, and contract was awarded on November 28. A Tri-Party Agreement change request was forwarded to the regulators proposing a new milestone date be established by January 31.

Tri-Party Agreement Milestone M-16-26C: M-16-26C, "Complete Remediation and Backfill of 10 Liquid Waste Sites and Process Effiuent Pipelines in the 100-HR-1 Operable Unit" by May 31, will be missed due to unanticipated elevated arsenic levels (resolved) and chromium sample analysis results that are above the remedial action goals encountered during confirmation sampling/verification activities.

Status: When the impact of the elevated chromium results is evaluated, a Tri-Party Agreement change package will be prepared.

300 Area Uranium Cleanup Level: EPA accepted the Preliminary Remediation Goal developed for uranium by the ERC. However, Ecology had additional concerns with protection of groundwater from uranium contamination in the 300 Area. EPA requires a $K d$ study to address uranium mobility in the 300 Area. This study will consist of obtaining uraniumcontaminated samples and performing leach rates testing with follow-on absorption tests resulting in a $K d$ value.

Status: A data quality objective (DQO) is nearing completion to develop scope for the $K d$ study. This study is not currently funded in the FY01 Detailed Work Plan (DWP). FYO1 funded scope will be completed, and a BCP will be prepared to secure funding for the remainder of workscope developed as a result of the DQO.

100 D Area Backfill: Backfill concurrence for the remaining north segment of the 100-DR north pipeline continues to be delayed pending resolution of a chromium issue. Additional samples have been collected and independently analyzed by three laboratories, with conflicting results. Ecology prefers that another qualified laboratory be utilized for further ana/ysis.

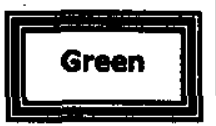

Status: Results from a fourth qualified laboratory confirmed that chromium concentration are not present above the cleanup level established in the $K d$ study. Regulators have agreed to proceed with backfill concurrence and closeout.

EXTERNAL ISSUES (i.e. HAB, Congress, etc.): RAWD None identified at this time.

DOE-RL \& HQ ISSUES/REQUESTS (not covered elsewhere): RAWD

None identified at this time.

\section{INTEGRATION ACTIVITIES: RAWO}

A Memorandum of Understanding (MOU) was signed with Energy Northwest for transportation and disposal of Hanford Generating Plant wastes. Energy Northwest will begin dismantlement of the Hanford Generating Plant in January with removal of the pipe trestle that connects the plant with the $100 \mathrm{~N}$ Reactor complex. The overall dismantling project is expected to take two years to complete. All materials that are radiologically contaminated will be sent to ERDF for disposal. 


\section{ENVIRONMENTAL MANAGEMENT PERFORMANCE REPORT ENVIRONMENTAL RESTORATION}

DECEMBER 2000

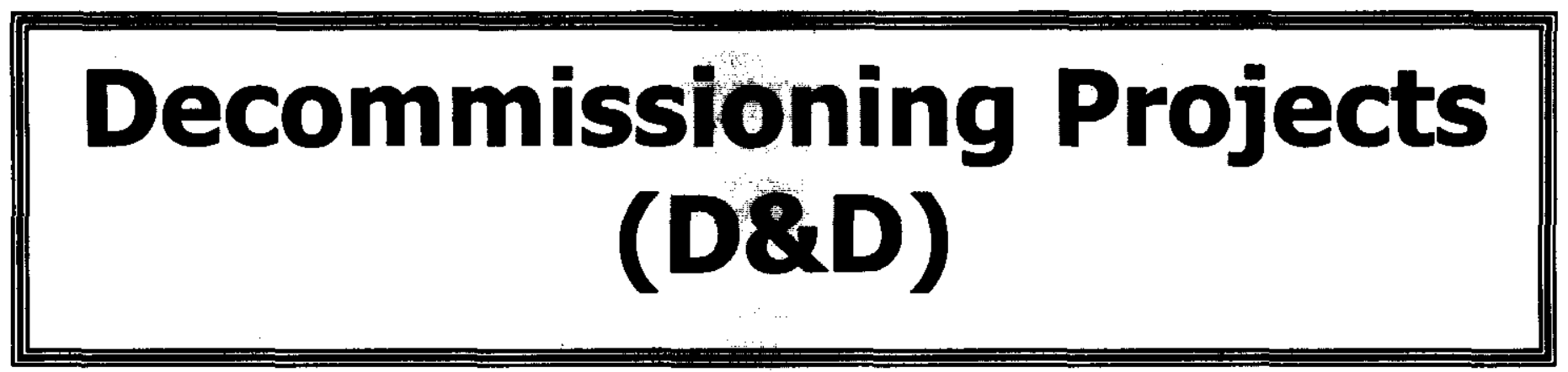




\title{
ENVIRONMENTAL MANAGEMENT PERFORMANCE REPORT ENVIRONMENTAL RESTORATION \\ DECEMBER 2000
}

\section{SECTION B - RESTORING THE RIVER CORRIDOR}

\author{
Financial / Performance Measures data as of month-end October. \\ All other data as of November 30, 2000 (unless otherwise noted). \\ Decommissioning Projects (D\&D)
}

\section{ACCOMPLISHMENTS: D\&D}

F and DR Reactor Interim Safe Storage (ISS): During October, demolition and loadout were completed for the $F$ Reactor fuel storage basin (FSB) above-grade structure, transfer bay, and rear-face stainwells. At DR Reactor, demolition was also completed for the rear-face stainwells, and loadout is in progress. Backfill was completed for DR Reactor FSB and valve pit areas.

D and H Reactor ISS: On October 17, the action memorandum for D and H Reactors ISS was approved by the regulators. Several other documents in support of the D and H Reactor ISS are nearing completion. The $H$ Reactor Auditable Safety Analysis (ASA), Rev. O was transmitted to RL on October 12 for approval. The Safety Evaluation Report (SAR) is being drafted for H Reactor. On October 16, the draft D and H Reactor Waste Designation Sampling and Analysis Plan (SAP) was transmitted to the regulators for review and comments. Comments were also incorporated into the draft D and H Reactor's Removal Action Work Plan and was forwarded to $R L$ on October 25 for review.

At $D$ Reactor, support areas are being established for asbestos abatement activities in reactor Areas 1 and 2. Hazardous materials were also removed from Areas 1 and 2. Craft walkdowns were performed prior to asbestos abatement work package completion.

233-S Plutonium Concentration Facility Decommissioning Project: Good progress continues to be made at the 233-S facility, despite the confined workspace environment and contamination hazards that are encountered during each entry. In October, 233-5 facility activities included the following:

- Installation of covers on all roof exhaust ports.

- Conducting pre-job and mock-up training for the L-18 (approximately four stories high) vessel pipe tapping process.

- Establishment of contamination control areas in preparation for L-18 vessel low point checks.

- Initiation of low point checks (pipe tapping) on L-18 vessel piping. No liquids were discovered.

- Initiation of electrical conduit removal from the L-18 vessel area on the second, third, and fourth floors.

- Completion of east weather enclosure decontamination and set-up for the continuation of waste removal.

- Transmission of the revised fire hazards evaluation to RL for review and approval.

- Submission of the Authorization Basis annual update for distribution. 


\section{ENVIRONMENTAL MANAGEMENT PERFORMANCE REPORT ENVIRONMENTAL RESTORATION \\ DECEMBER 2000}

\section{SAFETY/ISMS/CONDUCT OF OPERATIONS: DBD}

See Executive Summary.

\section{BREAKTHROUGHS/OPPORTUNITIES FOR IMPROVEMENT: D\&D}

None identified at this time.

\section{LONG-TERM (6 MONTHS PLUS) IMPORTANT ITEMS: D\&D}

None identified at this time.

\section{MAJOR COMMITMENTS (FISCAL YEAR PLUS 6 MONTHS): D\&D}

- DOE Secretarial:

None identified at this time.

- DOE EM Performance Agreement:

None identified at this time.

\section{- TPA Milestones:}

\begin{tabular}{|l|l|l|l|} 
Milestone & \multicolumn{1}{|c|}{ Description } & Due Date & \multicolumn{1}{|c|}{$(\mathrm{F}) /(\mathrm{A})$} \\
*M-93-12 & $\begin{array}{l}\text { Issue 105-DR Disposition Compettive } \\
\text { Procurement Package for Ascertaining the Most } \\
\text { Effective and Efficient Approach to FEIS ROD } \\
\text { Selected Alternative Implementation (....) }\end{array}$ & $2 / 28 / 02$ & \\
\hline
\end{tabular}

*Regulators have agreed to renegotiate this milestone since DR Reactor ISS is scheduled for completion in FY02. Discussions are underway.

- DNFSB Commitment:

None identified at this time. 


\section{ENVIRONMENTAL MANAGEMENT PERFORMANCE REPORT ENVIRONMENTAL RESTORATION \\ DECEMBER 2000}

\begin{tabular}{|c|c|c|c|c|}
\hline PI & $\begin{array}{l}\% \text { FY01 Fee Pool } \\
\text { Less } 10 \% \text { for } \\
\text { Comprehensive }\end{array}$ & $\begin{array}{c}\text { PI } \\
\text { Allocation } \\
\text { of Fee }\end{array}$ & Task & Status \\
\hline $233-5$ & $\begin{array}{l}13 \% \text { plus FY02 } \\
\text { equivalent portion }\end{array}$ & $76 \%$ & $\begin{array}{l}\text { - } 8 \text { vessels by } \\
6 / 30 / 02 \\
\text { - } 7 \text { vessels by } \\
6 / 30 / 02 \text { (*Stretch) } \\
\text { CV }<5.0 \% \text {; SV }<7.5 \% \\
\text { for PBS ER-06 }\end{array}$ & $\begin{array}{l}\text { Critical path } \\
\text { activity on } \\
\text { schedule. } \\
\text { None } \\
\text { commenced as } \\
\text { of } 10 / 31 / 00 \text {. }\end{array}$ \\
\hline ISS & $11 \%$ & $\begin{array}{l}35 \% \\
15 \% \\
35 \% \\
15 \%\end{array}$ & $\begin{array}{l}\text { D Reactor Major } \\
\text { Tasks by 9/30/01 } \\
\text { DR Reactor Major } \\
\text { Tasks by } 9 / 30 / 01 \\
\text { F Reactor Major } \\
\text { Tasks by } 9 / 30 / 01 \\
\text { H Reactor Major } \\
\text { Tasks by } 9 / 30 / 01 \\
\text { CV <5.0\%; SV <7.5\% } \\
\text { for PBS ER-06 }\end{array}$ & $\begin{array}{l}\text { Critical path } \\
\text { activity on } \\
\text { schedule, } \\
\text { however need } \\
\text { authorization } \\
\text { funding to } \\
\text { proceed with } \\
\text { work by } \\
12 / 15 / 00 \text {. }\end{array}$ \\
\hline
\end{tabular}




\section{ENVIRONMENTAL MANAGEMENT PERFORMANCE REPORT \\ ENVIRONMENTAL RESTORATION \\ DECEMBER 2000}

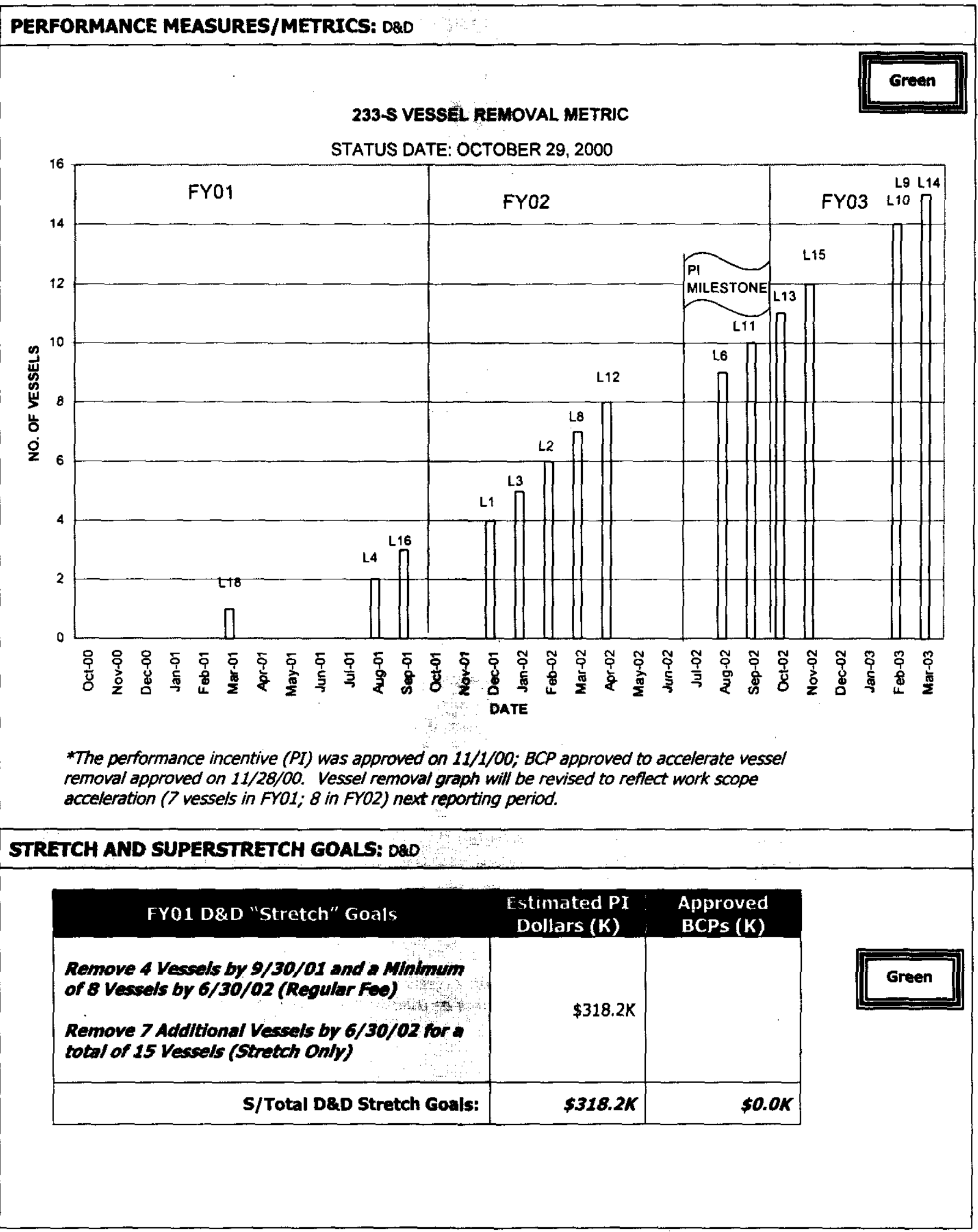




\section{ENVIRONMENTAL MANAGEMENT PERFORMANCE REPORT ENVIRONMENTAL RESTORATION \\ DECEMBER 2000}

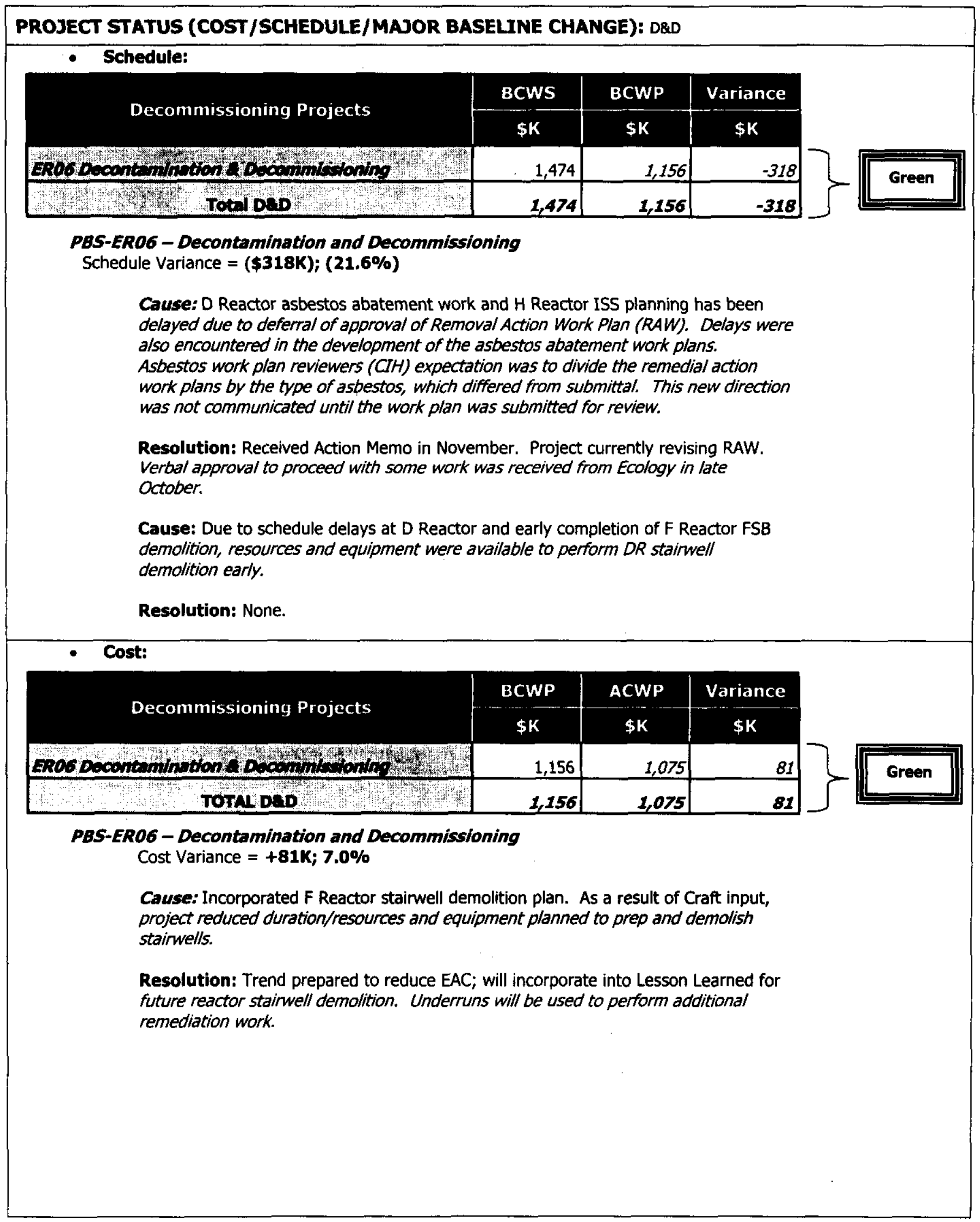




\title{
ENVIRONMENTAL MANAGEMENT PERFORMANCE REPORT ENVIRONMENTAL RESTORATION \\ DECEMBER 2000
}

\begin{abstract}
REGULATORY ISSUES: D\&D
D\&H Reactor: The approved Action Memorandum and Removal Action Work Plan (RAW) were scheduled for completion in FYOO for D \& H Reactors.

Status: Trending impacts to schedule. The Action Memo has been signed and was transmitted from Ecology to DOE. Informal comments on the RAW were addressed with Ecology and approved mid-November. Verbal approval to proceed with some work at $D \& H$ Reactors was received from Ecology as per the draft RAW in late October.

ISS Pourback Subcontract: The current contract for pourback work terminates in December, but additional funds for continuing ISS has not been authorized.

Status: RMT approved moving forward on pourbacks, a BCP is in process. The work will be treated as emerging work and will be offset by the deletion of the enclosure from the F Reactor FSB. Without an overall ISS funding appropriation, ISS work will need to be curtailed in December when the partial Fy01 funding has been expended.
\end{abstract}

233-S Waste Handling: Handling packaged waste at 233-S resulted in a minor release of contamination in the weather enclosure radiological boundary area. Work was halted for a short time until the area was decontaminated.

Status: A waste package handling methodology is being established that minimizes package size and package handling between removal from the building until placement in a designated waste container. This should reduce the potential for packaging failures.

233-S Process Hood: To support FY01 decommissioning activities in the 233-S Process Hood, non-destructive assay (NDA) support (provided by FH-PFP) was planned on a full-time basis. To-date, the support has been less than required. Although NDA support has not yet become a critical path item, it has the potential to impact the rate of equipment removal from the process cell.

Status: Continue to work with the NDA provider to insure adequate support exists on a continuing basis.

EXTERNAL ISSUES (i.e. HAB, Congress, etc.): DQD

None identified at this time.

DOE-RL \& HQ ISSUES/REQUESTS (not covered elsewhere): D\&D None identified at this time.

INTEGRATION ACTIVITIES: D\&D

None identified at this time. 
ENVIRONMENTAL MANAGEMENT PERFORMANCE REPORT

ENVIRONMENTAL RESTORATION

DECEMBER 2000

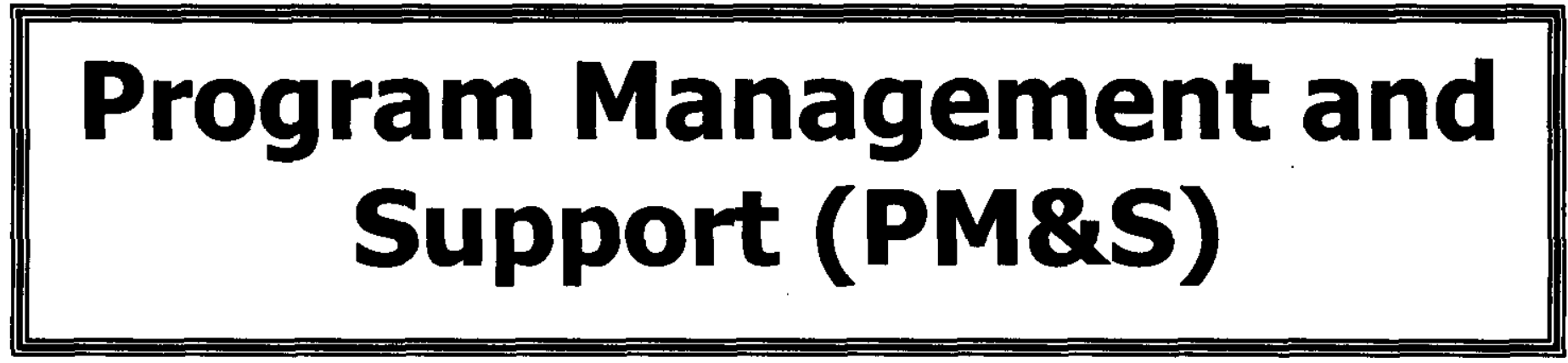




\title{
ENVIRONMENTAL MANAGEMENT PERFORMANCE REPORT ENVIRONMENTAL RESTORATION \\ DECEMBER 2000
}

\section{SECTION B - RESTORING THE RIVER CORRIM}

\author{
mand / Performance Menctartata as of month-end oct \\ all other data as of Novembr \\ 7000 (unless otherwise butat
}

Program Management \& Support (PM\&S)

ACCOMPLISHMENTS: PMES

COMPLIANCE, QUALTTY, SAFETY, AND HEALTH:

Safety and Health: RadCon established a release plan for 2,500 lead bricks at a $100 \mathrm{H}$ Area remediation waste site. This release plan is a result of a consent agreement and final order issued by the EPA, Region 10 to close out the findings of the 1998 multi-media inspection. Each of the 2,500 lead bricks will be surveyed and released in accordance with the requirements set forth in DOE Order 5400.5 (Radiation Protection of the Public and Environment) and all applicable DOE Secretarial memoranda addressing the release of such material.

Compliance and Quality Programs: During October, Compliance and Quality Programs identified two compliance areas needing correction. Two reports were filed with the DOE noncompliance tracking system (NTS) for Price Anderson Amendment Act issues. One report identified a subcontractor that failed to adequately implement a Quality Assurance Program

Plan. The other report identified events involving fallure to adequately control alpha contamination. An in-depth analysis for potential common causes is underway. A report will be issued to the NTS by December 4.

\section{PROGRAM AND PROJECT SUPPORT:}

External Affairs: On October 10-11, ER participated in the "Hanford 2012: Accelerating Cleanup and Shrinking the Site" workshop that was conducted for the Hanford Advisory Board (HAB) Committee members to provide a better understanding of the drivers, assumptions, and key policy issues underlying RL's new management direction for site cleanup.

Support was provided to the Oregon Office of Energy in planning the October 23-24 Oregon Hanford Waste Board meeting. Presentations were given on the ER Project Update and the 618-11 Burial Ground sampling activities.

\section{ENGINEERING AND TECHNOLOGY:}

Environmental Technologies: Hanford comments on Ecology's proposed revisions to the Model Toxic Control Act (MTCA) cleanup regulations (WAC 173-340) were submitted to Ecology. The comments raised concerns on many aspects of the proposed changes, particularly with regard to the proposed methodology for establishing cleanup levels for ecological receptors.

The chemical management verification report was completed and distributed to Chemical Custodians, Environmenta/ Leads, and applicable Project and Functional Managers. Overall, the ERC is effectively implementing the Chemical Management Program (CMP), and field personnel have improved tracking of chemicals consistent with CMP requirements.

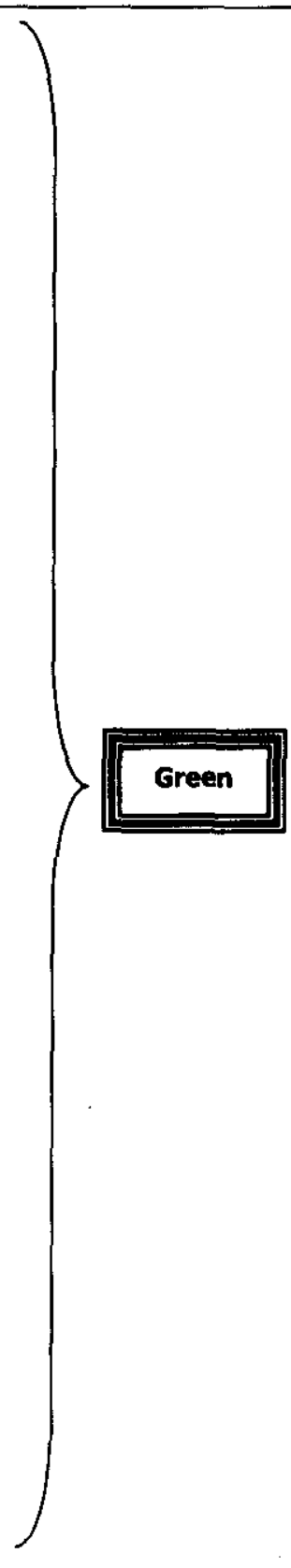




\section{ENVIRONMENTAL MANAGEMENT PERFORMANCE REPORT ENVIRONMENTAL RESTORATION \\ DECEMBER 2000}

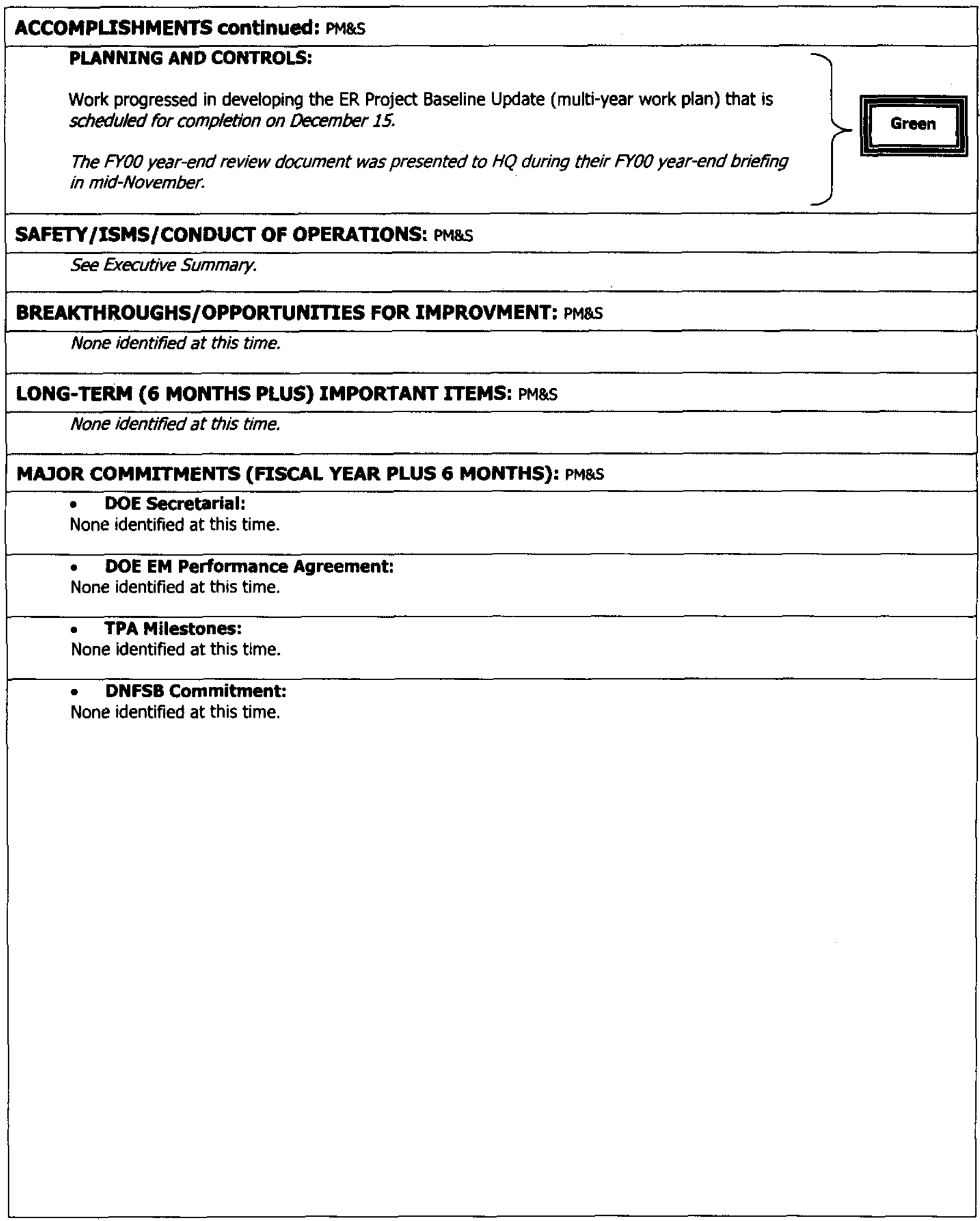




\section{ENVIRONMENTAL MANAGEMENT PERFORMANCE REPORT ENVIRONMENTAL RESTORATION \\ DECEMBER 2000}

PERFORMANCE OBJECTIVES: PM\&S

\begin{tabular}{|c|c|c|c|}
\hline $\begin{array}{c}\text { Comprehensive } \\
\text { Measures }\end{array}$ & Fee Allocation & abs & Status \\
\hline Safety & $\begin{array}{l}\text { Negative Fee up } \\
\text { to } 50 \% \text { of fee } \\
\text { available for } \\
\text { comprehensive } \\
\text { PI }\end{array}$ & $\begin{array}{l}\text { The Contractor } \\
\text { shall protect worker } \\
\text { safety and health, } \\
\text { public safety and } \\
\text { health, and the } \\
\text { environment. }\end{array}$ & $\begin{array}{l}\text { No concerns identified } \\
\text { during October. }\end{array}$ \\
\hline $\begin{array}{l}\text { Operational } \\
\text { Excellence }\end{array}$ & $\begin{array}{l}\text { Positive Fee up } \\
\text { to } 55 \% \text { of fee } \\
\text { available for } \\
\text { comprehensive } \\
\text { PI }\end{array}$ & $\begin{array}{l}\text { - Migrate systems to } \\
\text { facilitate PBS } \\
\text { restructuring in FYO2 } \\
-75 \% \\
\text { - Rebaseline } \\
\text { completed per } \\
\text { Baseline Updating } \\
\text { Guidance (BUG) - } \\
20 \% \\
\text { Integrate } \\
\text { technology into } \\
\text { Projects - 10\% } \\
\text { Achieve pollution } \\
\text { prevention/waste } \\
\text { minimization - 10\% }\end{array}$ & $\begin{array}{l}\text { All activities on } \\
\text { schedule. }\end{array}$ \\
\hline $\begin{array}{l}\text { Effective } \\
\text { Leadership }\end{array}$ & $\begin{array}{l}\text { Positive Fee up } \\
\text { to } 45 \% \text { and } \\
\text { Negative Fee up } \\
\text { to } 50 \% \text { of fee } \\
\text { available for } \\
\text { comprehensive } \\
\text { PI }\end{array}$ & $\begin{array}{l}\text { - Management } \\
\text { Effectiveness } \\
\text { Customer } \\
\text { Satisfaction } \\
\text { Effective Financial } \\
\text { Management }\end{array}$ & $\begin{array}{l}\text { No concerns identified } \\
\text { during October. }\end{array}$ \\
\hline
\end{tabular}

PERFORMANCE MEASURES/METRICS: PM\&S

*A technology deployment plan will be developed in January 2001 as identified in the DWP.

\begin{tabular}{|c|c|c|c|}
\hline Technology Deployment & PBS & $\begin{array}{l}\text { Planned } \\
\text { Date }\end{array}$ & $\begin{array}{c}(F) /(A) \\
\text { Date }\end{array}$ \\
\hline$* N / A$ & N/A & $N / A$ & $N / A$ \\
\hline
\end{tabular}

STRETCH AND SUPERSTRETCH GOALS: PM\&S

None identified at this time. 


\section{ENVIRONMENTAL MANAGEMENT PERFORMANCE REPORT ENVIRONMENTAL RESTORATION \\ DECEMBER 2000}

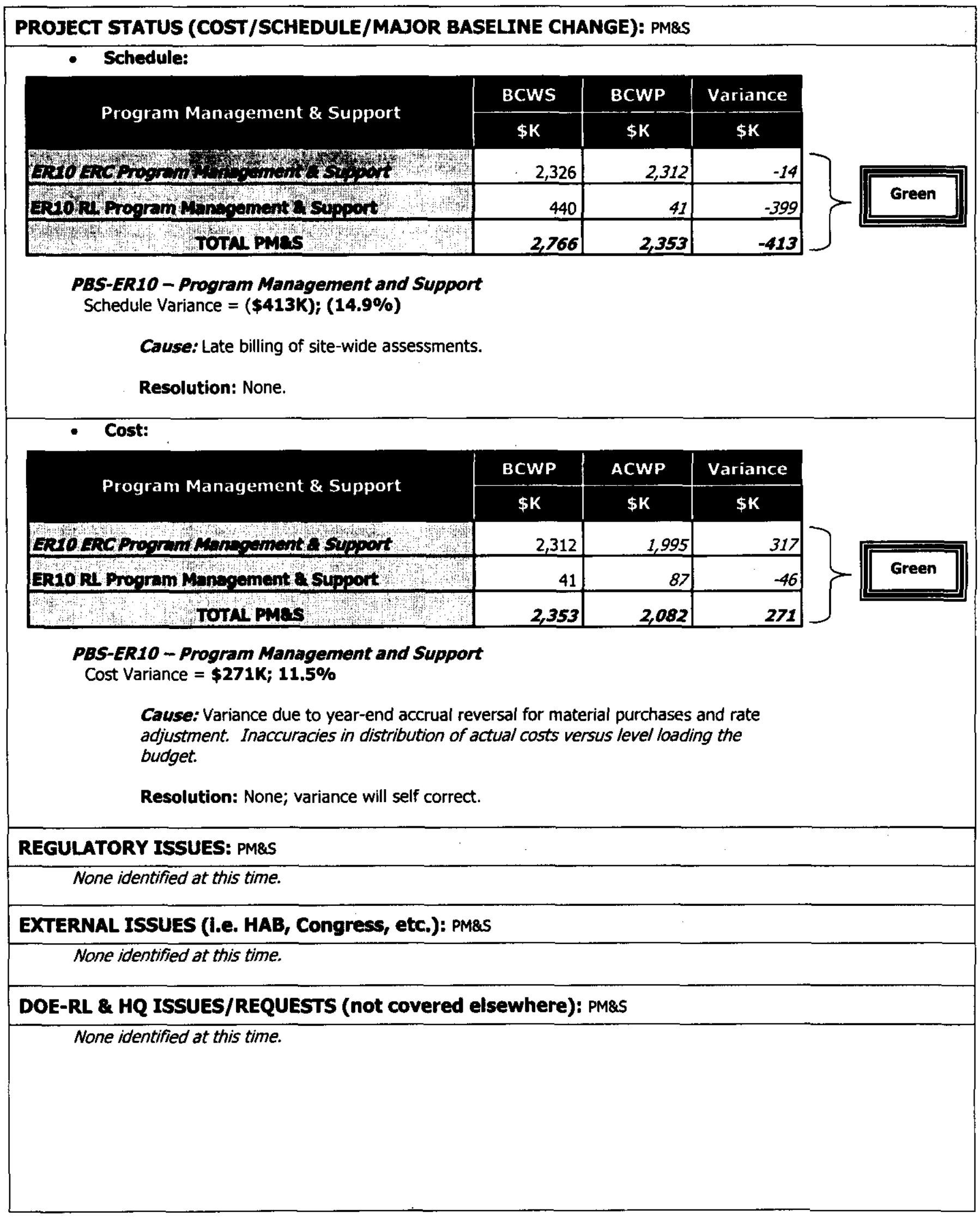




\section{ENVIRONMENTAL MANAGEMENT PERFORMANCE REPORT ENVIRONMENTAL RESTORATION \\ DECEMBER 2000}

\section{INTEGRATION ACTIVITIES: PM\&S}

Bechtel Hanford, Inc. (BHI) closed a significant RL action item in October with implementation of an Employee Job Task Analysis (ETAA) program for subcontractors. BHI, along with Pacific Northwest National Laboratory (PNNL) and Fluor Hanford (FH), spent two years in developing a site-wide program to assess hazards and perform medical monitoring for subcontractor personnel who might be at risk of potential exposure. The primary implementation tool for the Hanford contractors involves incorporation of specific contract language and partnering with the subcontractor to ensure employees who are at risk of exposure are captured in the ETTA database.

In October, a joint BHI, FH, and PNNL team conducted a "Hanford Analytical Services" presentation at the National Sample Management Organization Workshop at Oak Ridge National Laboratory. Hanford Analytical Services is a joint RL, BHI, FH, and PNNL board that coordinates laboratory services for the Hanford Site. HQ representatives complimented the team on their presentation and stated that the Hanford Analytical Services board provides a good model for other DOE sites.

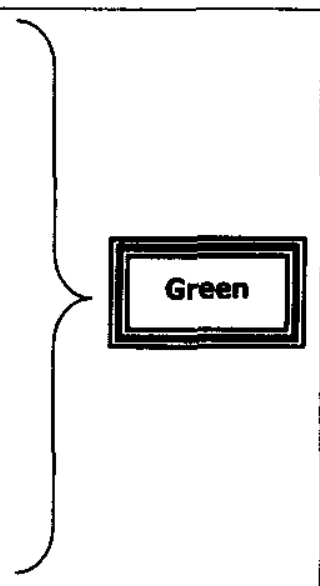




\section{Richland Operations Office Environmental Restoration \\ Environmental Management Performance Report}

\section{Section C - Central Plateau Intolnz}

December 2000

- Groundwater / Vadose Zone Integration Project
- Surveillance / Maintenance \& Transition Projects

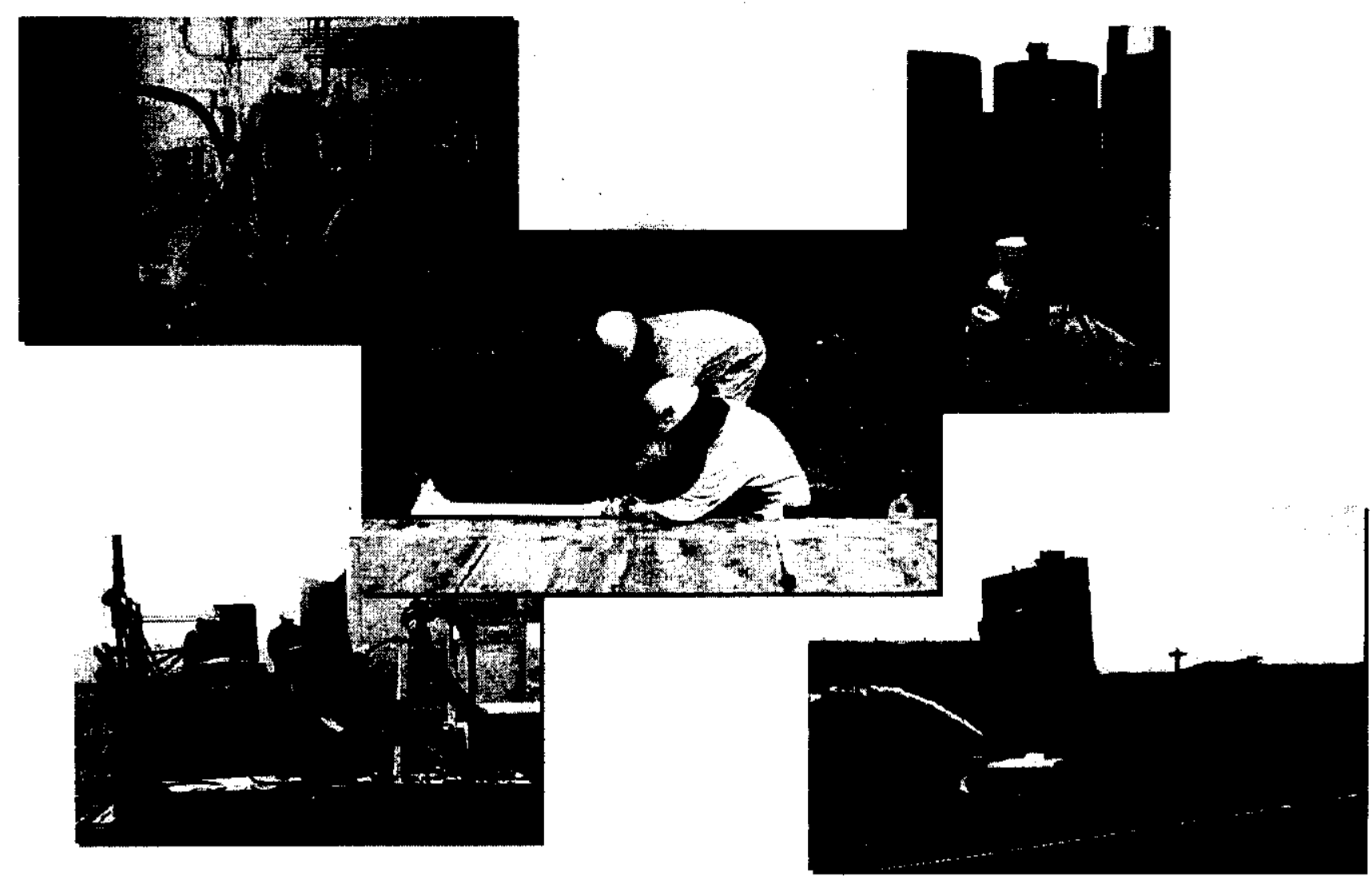

Focused on Progress...

Focused on Outcomes!

Department of Energy Richland Operations Office
Bechtel Hanford, Inc. Environmental Restoration Contractor 


\section{ENVIRONMENTAL MANAGEMENT PERFORMANCE REPORT \\ ENVIRONMENTAL RESTORATION \\ DECEMBER 2000}

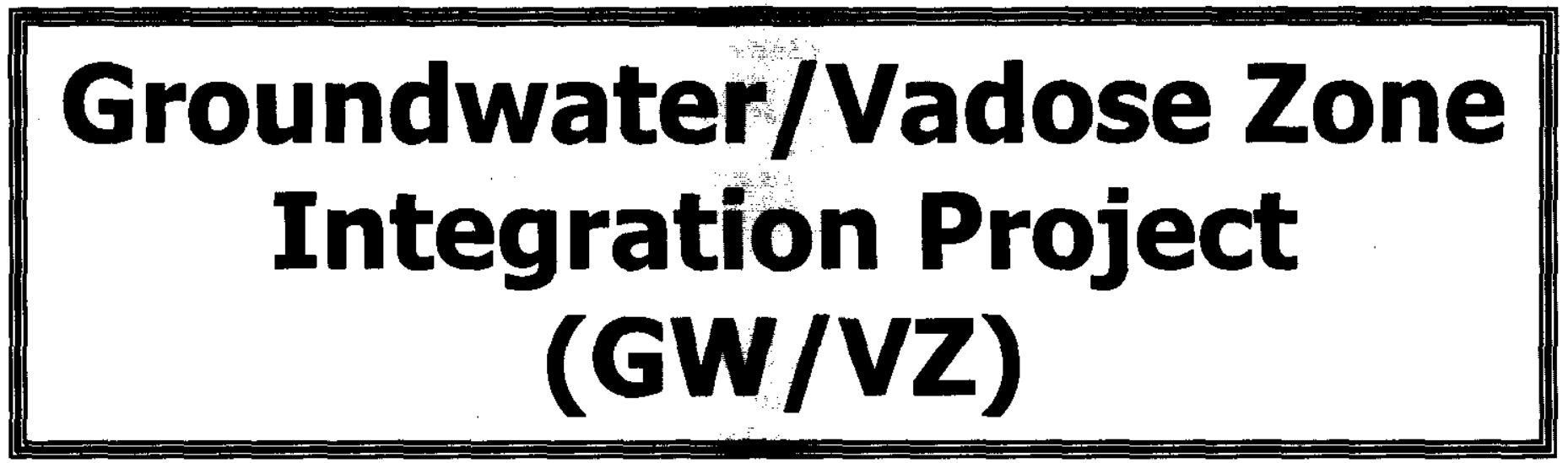




\title{
ENVIRONMENTAL MANAGEMENT PERFORMANCE REPORT ENVIRONMENTAL RESTORATION \\ DECEMBER 2000
}

\section{SECTION C - TRANSITIONING THE CENTRAL PLATEAU}

\author{
Financial / Performance Measures data as of month-end October.
}

All other data as of November 30, 2000 (unless otherwise noted).

Groundwater/Vadose Zone Integration Project(GW/VZ):

ACCOMPLISHMENTS: GW/NZ

GW/VZ INTEGRATION PROJECT:

Peer Review: The Integration Project Expert Panel meeting \#8 was conducted in October. This meeting focused on Columbia River issues and resolutions.

Science and Technology: The draft of the Risk Assessment Science and Technology Plan was completed in October. This plan answered a second set of questions to provide the basis for a November meeting with the National Academy of Science committee.

System Assessment Capabillty: Historical matching was initiated with the System Assessment Capability (SAC) Rev. O capability. The purpose of historical matching is to assess the ability of SAC Rev. O predictions to match observations and identify improvements needed prior to the initial assessment.

\section{GROUNDWATER MANAGEMENT:}

In Situ Redox Mamipulation Project: All ten wells planned were chemically injected in FYO0, and chemical barrier withdrawal on two wells was completed during October. Only one well remains to complete withdrawal activities, which is scheduled for completion in December.

Long-Term Groundwater Monitoring: A RCRA well installation workshop was held on October 4 with Ecology, RL, Office of River Protection (ORP), and contractors. The list of recommended wells for installation in calendar year 2001 to support the Tri-Party Agreement M-24 milestone was presented to Ecology.

Tritium Investigation: Several activities were completed during October in support of the tritium investigation in the 618-11 Burial Ground. Two boreholes were drilled (one on the north side, and the other on the east side of the burial site). Grab samples were obtained and submitted for analysis. Borehole decommissioning was also completed as part of the continuing investigation.

Summary of Five Pump and Treat Systems: All groundwater pump and treat systems operated above the planned $90 \%$ availability levels in October. Since system inception, the five pump and treat systems have processed over 4.4 billion liters of groundwater, removing approximately 4,713 kilograms of carbon tetrachloride, 202 kilograms of chromium, and 0.91 curies of strontium. Approximately 118 million liters of groundwater have been processed in FY01, removing approximately 131 kilograms of carbon tetrachloride, 9 kilograms of chromium, and 0.022 curies of strontium.

100-HR-3 Pump and Treat System: Approximately 27.8 million liters of groundwater were processed in October removing approximately 4.5 kilograms of chromium. Approximately 971 million liters of groundwater have been processed from inception to date, with 96.1 kilograms of chromium removed.

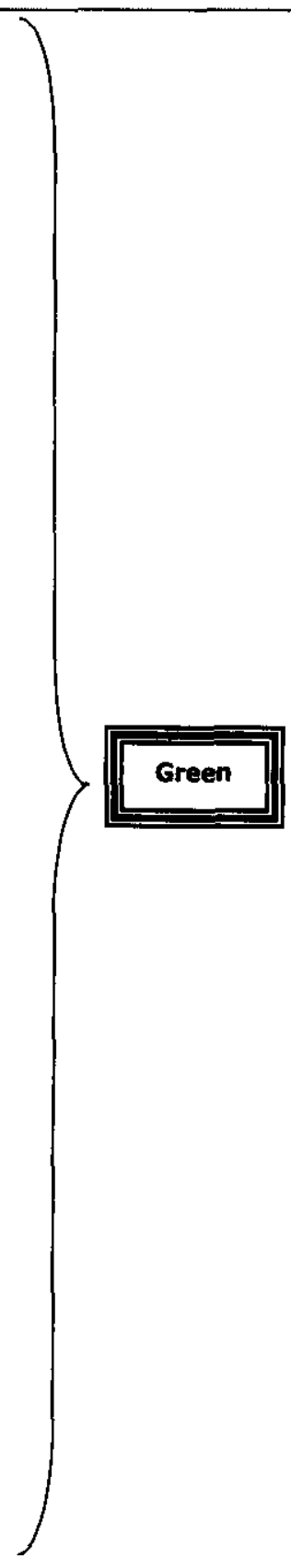




\title{
ENVIRONMENTAL MANAGEMENT PERFORMANCE REPORT ENVIRONMENTAL RESTORATION \\ DECEMBER 2000
}

\section{ACCOMPLISHMENTS continued: GW/VZ}

100-KR-4 Pump and Treat System: Approximately 33.8 million liters of groundwater were processed in October removing approximately 4.1 kilograms of chromium. Approximately 843 million liters of groundwater have been processed from inception to date, with 106.2 kilograms of chromium removed.

100-NR-2 Pump and Treat System: Approximately 10.8 million liters of groundwater were processed in October, removing approximately 0.022 curies of strontium. Approximately 553 million liters have been processed from inception to date, with 0.910 curies of strontium removed.

200-UP-1 Pump and Treat System: Approximately 9.2 million liters of groundwater were processed in October. From inception to date, approximately 446 million liters have been transported to the Effluent Treatment Facility (ETF) for processing. 343.0 million liters were previously processed prior to utilizing the ETF.

200-ZP-1 Pump and Treat System: Approximately 36.3 million liters of groundwater were processed during October removing 131.3 kilograms of carbon tetrachloride. From inception to date, approximately 1.3 billion liters have been processed, with 4,713 kilograms of carton tetrachloride removed.

200-ZP-2 Vapor Extraction System: The 200-ZP-2 soil vapor extraction system was placed off-line in FYOO, in order to monitor and evaluate any rebounding of contaminant to static conditions. The resulting data will be used to evaluate the effectiveness of remediation on contaminants within the vadose zone. The passive vapor extraction system (installed in selected vadose zone wells) is performing as designed. Monthly sampling will continue. $A$ meeting was held on November 7 with the regulators, RL, and contractors to discuss a path forward on Dense Non-Aqueous Phase Liquid (DNAPL) investigation. It was agreed that the Partitioning Interwell Tracer Test (PITT) was too expensive for a speculative location of the test. The PITT test will be put on hold while further conventional characterization is performed.

\section{AREA ASSESSMENTS:}

Regulator approval was received for the 200-CS-1 and 200-CW-5 Operable Unit (OU) Rev. 0 Work Plans. Assessment field work can now proceed in these two OUs.

A Tri-Party Agreement change package was also submitted to the regulators proposing replacing the 200-PW-4 OU with the 200-PW-1 OU, which has a higher risk for carbon tetrachloride sites.

\section{SAFETY/ISMS/CONOUCT OF OPERATIONS: GWNZ}

\author{
See Executive Summary.
}

\section{BREAKTHROUGHS/OPPORTUNITIES FOR IMPROVEMENT: GW/VZ}

None identified at this time. 


\section{ENVIRONMENTAL MANAGEMENT PERFORMANCE REPORT ENVIRONMENTAL RESTORATION \\ DECEMBER 2000}

LONG-TERM (6 MONTHS PLUS) IMPORTANT ITEMS: GW/NZ.

None identified at this time.

MAJOR COMMITMENTS (FISCAL YEAR PLUS 6 MONTHS): GW/VZ

- DOE Secretarial:

None identified at this time.

- DOE EM Performance Agreement:

None identified at this time. 


\section{ENVIRONMENTAL MANAGEMENT PERFORMANCE REPORT ENVIRONMENTAL RESTORATION \\ DECEMBER 2000}

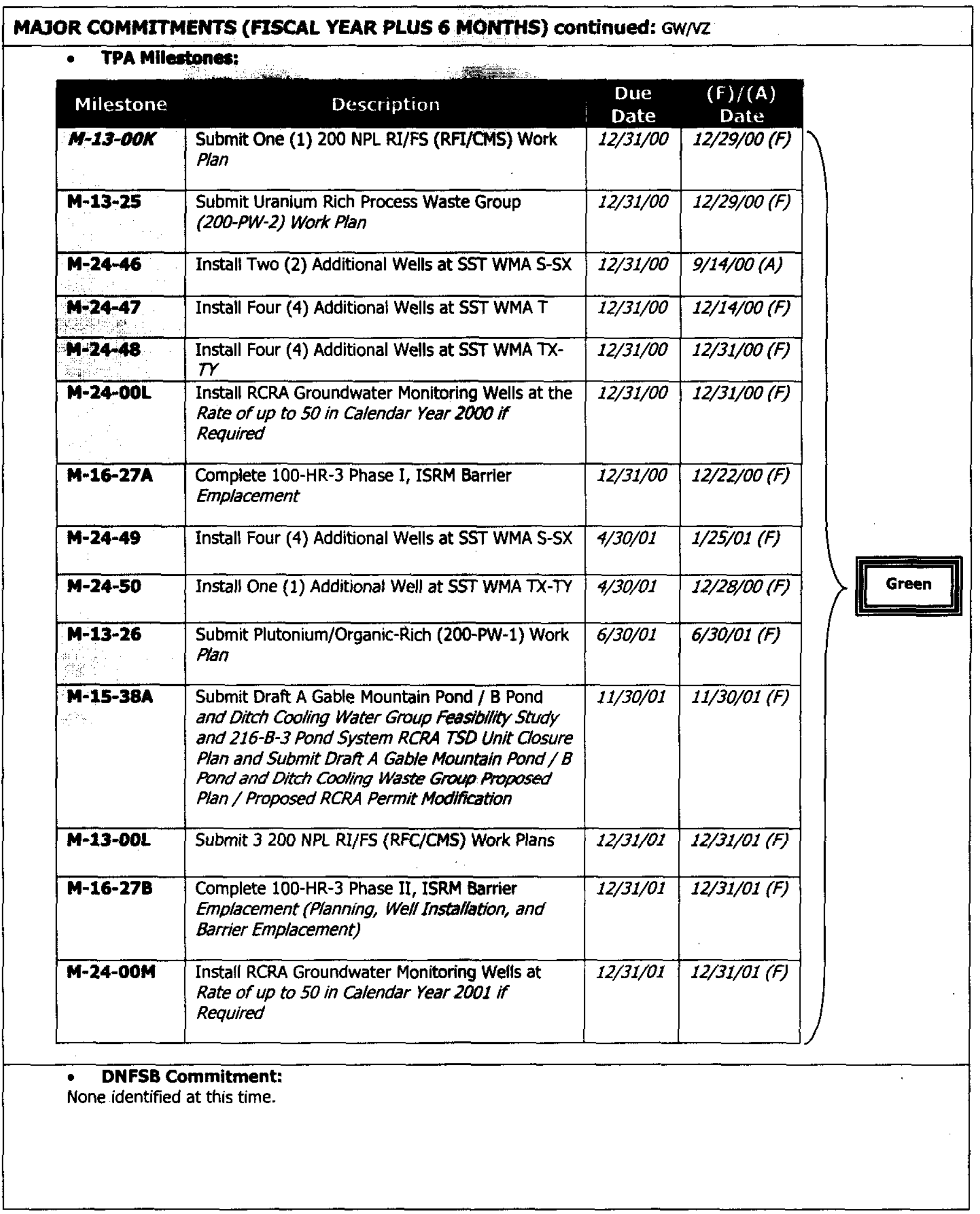




\section{ENVIRONMENTAL MANAGEMENT PERFORMANCE REPORT \\ ENVIRONMENTAL RESTORATION \\ DECEMBER 2000}

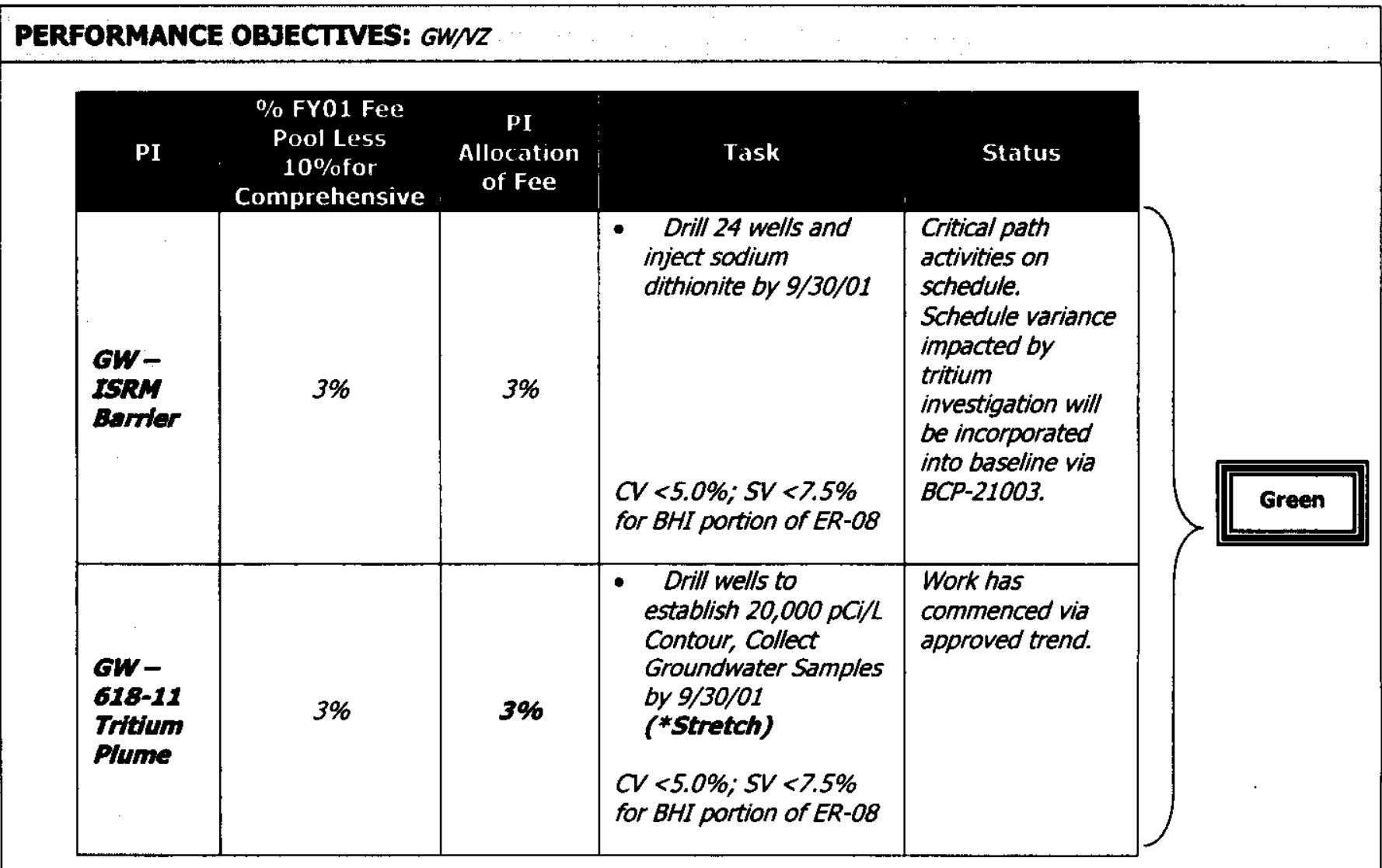

PERFORMANCE MEASURES/METRICS: GWNZ

FY01 Routine Well Maintenance Completion

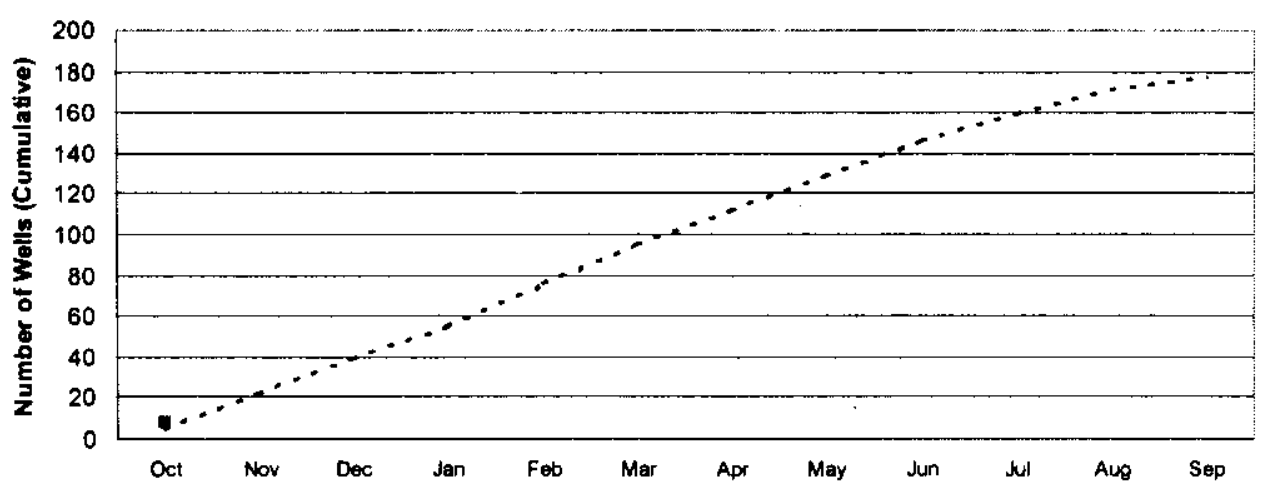

-..-Routine Well Maintenance F/C $\rightarrow$ Routine Well Maintenance Actual 


\section{ENVIRONMENTAL MANAGEMENT PERFORMANCE REPORT ENVIRONMENTAL RESTORATION \\ DECEMBER 2000}

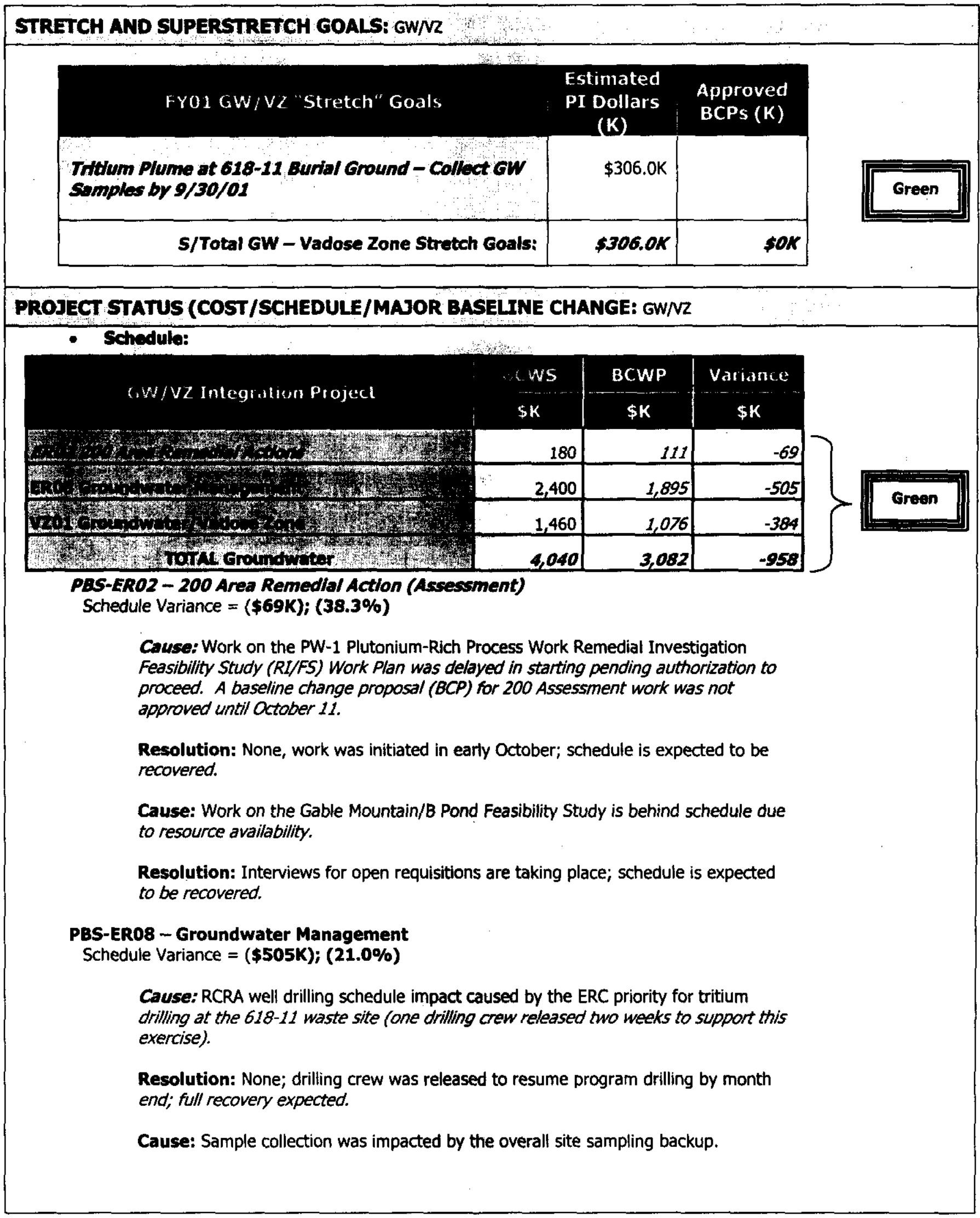




\title{
ENVIRONMENTAL MANAGEMENT PERFORMANCE REPORT ENVIRONMENTAL RESTORATION \\ DECEMBER 2000
}

\begin{abstract}
PROJECT STATUS (COST/SCHEDULE/MAJOR BASELINE CHANGE) continued: GW/NZ
Resolution: The well sampling subcontractor has increased the sampling teams from two to three to recover schedule.

PBS-VZ01 - Groundwater/Vadose Zone

Schedule Variance $=(\$ 384 K) ;(26.3 \%)$

Cause: Soil Waste Inventory - staff working on carryover items from FY2000. Work planned after DWP was finalized. Field Investigations at Representative Sites distribution of contaminated samples behind schedule due to date for receipt of samples from SX-108 later than planned and unresolved ES\&H issues. Contracts for other national laboratory involvement in Field Investigation at Representative Sites, Vadose Zone Transport Field Study, and Transport Modeling tasks not in place because of Continuing Resolution.

Resolution: BCP will be prepared to use variance on Soil Waste Inventory Task for other work. SX-108 samples distributed; contracts with the other national laboratories now in place; offline schedules prepared for tasks to ensure completion of milestones for input to RPP S-SX Field Investigation Report.
\end{abstract}

\begin{tabular}{|c|c|c|c|c|}
\hline \multirow{2}{*}{ GW/VZ Integration Project } & BCWP & ACWP & Variance & \multirow{4}{*}{ Green } \\
\hline & $\$ \mathbf{K}$ & $\$ \mathbf{K}$ & $\$ \mathbf{K}$ & \\
\hline 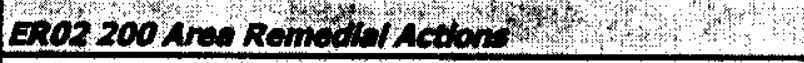 & 111 & 102 & 9 & \\
\hline ERos Groundwator Monhenon & 1,895 & 1,593 & 302 & \\
\hline 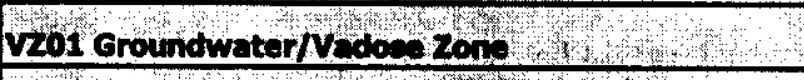 & 1,076 & 917 & 159 & \\
\hline 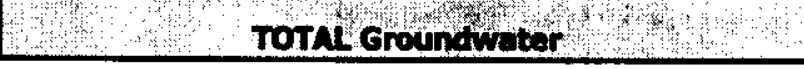 & 3,082 & 2,612 & 470 & \\
\hline
\end{tabular}

PBS-ERO2 - 200 Area Remedial Action(Assessment)

Cost Variance $=\mathbf{\$ 9 K ;} \mathbf{8 . 1 \%}$

Cause: There was a $\$ 9 \mathrm{~K}$ cost associated with preparing for and conducting site tours, which was not budgeted.

Resolution: Identify overruns in Trend Register.

PBS-ER08 - Groundwater Management

Cost Variance $=\$ \mathbf{3 0 2 K} ; \mathbf{1 5 . 9 \%}$

Cause: Less non-manual staff required on RCRA well drilling than planned; a processing delay in the October accruals on sampling and analysis.

Resolution: Accrual issues will be corrected. Cost underruns will be used to perform additional remediation work.

PBS-VZ01 - Groundwater/Vadose Zone

Cost Variance $=\$ \mathbf{1 5 9 K} ; \mathbf{1 4 . 8} \%$

Cause: Accruals for National Laboratory costs (FYOO carryover) were not made in October.

Resolution: Accruals will be corrected in November. 


\section{ENVIRONMENTAL MANAGEMENT PERFORMANCE REPORT ENVIRONMENTAL RESTORATION \\ DECEMBER 2000}

\section{REGULATORY ISSUES: GW/NZ}

Monitoring Wells: Tritium investigation is being conducted near the 618-11 Burial Ground.

Status: The groundwater grab results from the boreholes drilled for the 618-11 soil gas investigation have been evaluated. The groundwater grabs from boreholes C3264 and C3265 were to assess tritium levels in the groundwater and assist in the determination of a corre/ation between groundwater concentrations and the measured helium ratios.

As previously reported, borehole C3264 (about midway along the northern boundary of the 618-11 Burial Ground) was completed to groundwater and a groundwater grab sample was collected on October 9 . The initial results from the C-32-64 groundwater grab indicated tritium levels less than 30,000 pCi/liter. A split sample taken by the Department of Health gives the result of about 6,000 pCi/liter. The detection limits were much lower at laboratory used by the Department of Health.

Borehole C3265 (in the Energy Northwest parking lot, east of the 618-11 Burial Ground) was completed to groundwater and a groundwater grab sample was collected on October 13. The results of this sample is 1.5 million pCi/liter. This borehole is about 80 meters downgradient from well 699-13-3A. The split sample taken by the Department of Health corroborates this result.

200-2P-1/200-ZP-2: Need for enhanced characterization, enhance removal efficiency, and Dense Non-Aqueous Phase Liquid (DNAPL) investigation.

Status: A preliminary cost estimate and proposal submitted by a potential contractor has been reviewed by a subpanel of the GW/VZ Integration Project's Expert Panel. A meeting was held on November 7 with the regulators, the DOE, and Contractors to discuss a path forward on DNAPL Investigation. It was agreed that the Partitioning Interwell Tracer Test was too expensive for a speculative location of the test. The test will be put on hold for the time being while further conventional characterization is performed. We will meet again in early December with the regulators and DOE to plan characterization efforts. A concurrent effort is underway to submit a Groundwater initiative proposal for DNAPL Investigation and Remediation.

200 Area Remedial Investigation/Feasibility Study: Approximately 800 contaminated soil sites in the 200 Area, which have been grouped into 23 process-based operable units, are to be characterized by 2008 and remediated by 2018. Inadequate funding avallability projections do not support requirements.

Status: Tri-Party Agreement change packages for the 200-CW-1, 200-CW-5, and 200-CS-1 Operable Units containing RI/FS interim milestones were approved on August 23. In addition, RL is currently working on ways to revise the existing longterm strategy for prioritizing the 200 Area assessment and remediation activities in conjunction with other site cleanup decisions. In October, a BCP was approved for $\$ 4.5 \mathrm{M}$ to incorporate scope into the baseline. $R L$ is also seeking to justify and identify additional funds for characterization. RL is pursuing $\$ 2.5 \mathrm{M}$ additional authorization from other RL funding sources, and the ERC has identified $\$ 2.0 \mathrm{M}$ (from FYOO efficiencies) for FY01 workscope. The funding for the $\$ 2.5 \mathrm{M}$ needs to be identified by $R L$ before December in order to place contracts. 


\section{ENVIRONMENTAL MANAGEMENT PERFORMANCE REPORT ENVIRONMENTAL RESTORATION \\ DECEMBER 2000}

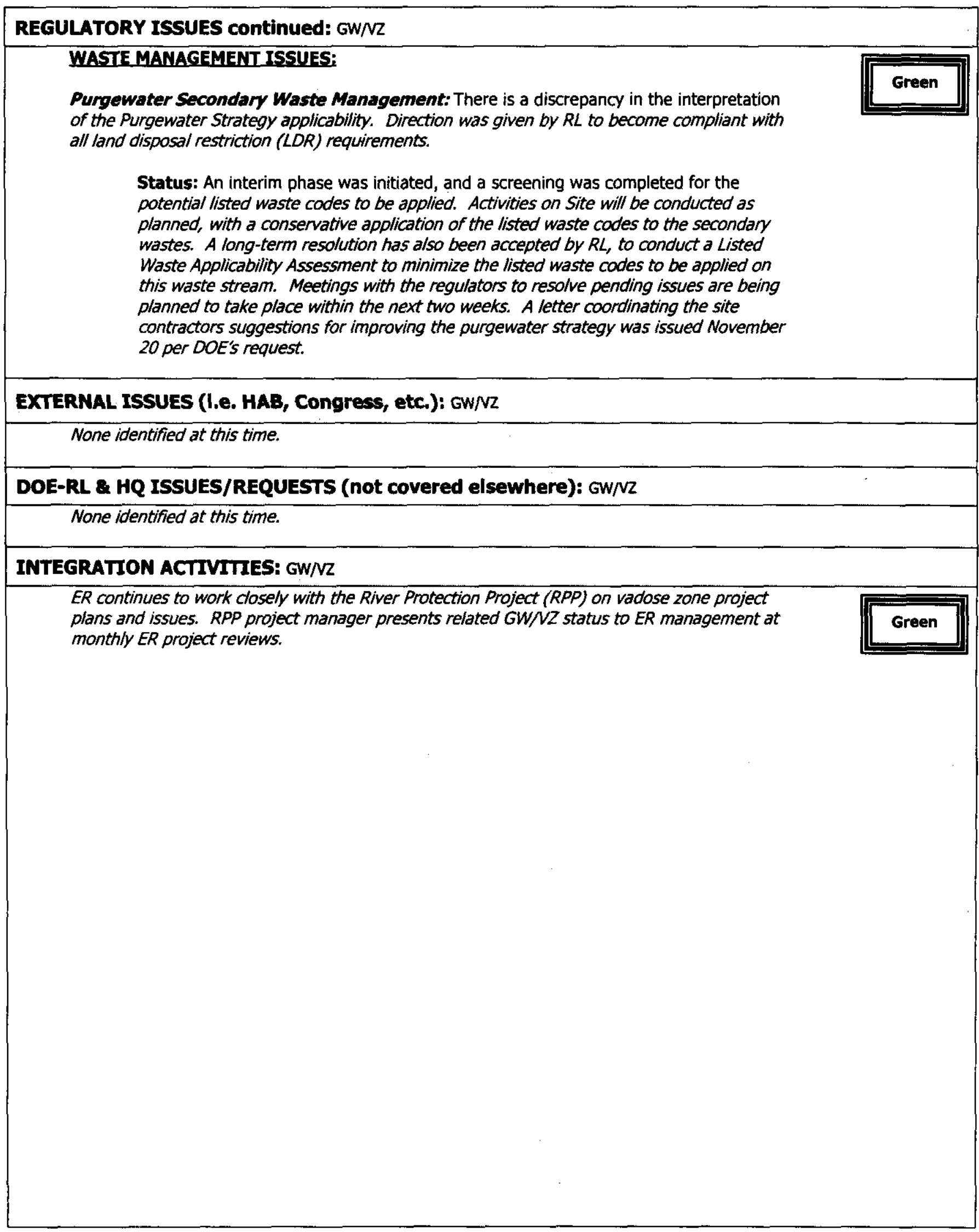


ENVIRONMENTAL MANAGEMENT PERFORMANCE REPORT

ENVIRONMENTAL RESTORATION

DECEMBER 2000

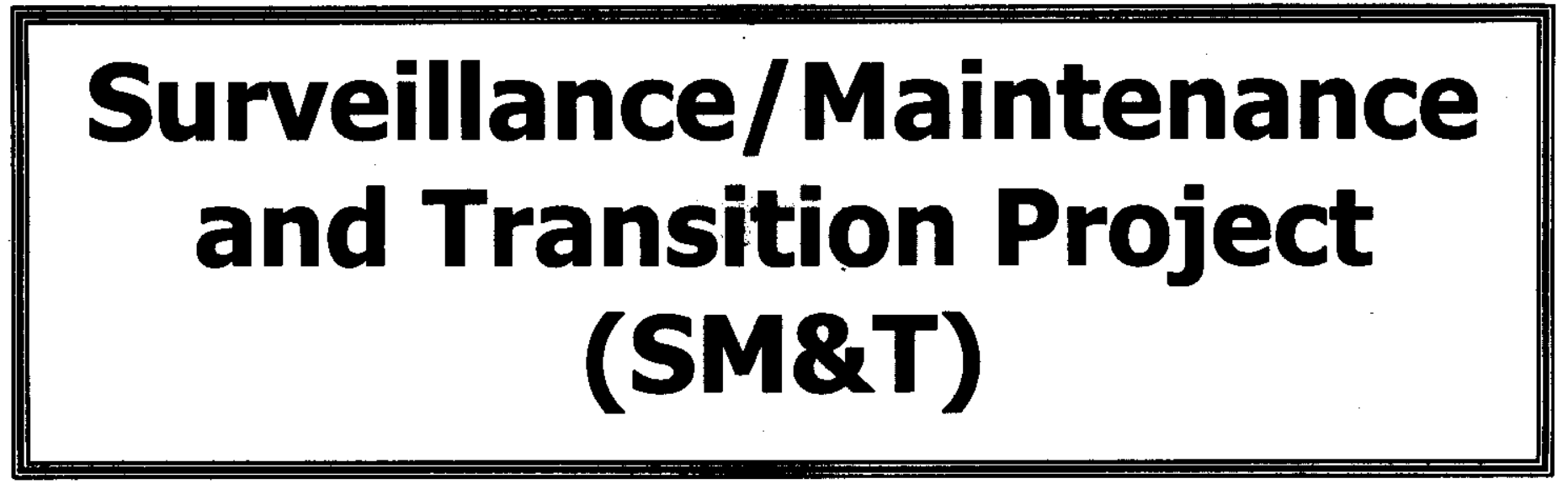




\section{ENVIRONMENTAL MANAGEMENT PERFORMANCE REPORT ENVIRONMENTAL RESTORATION \\ DECEMBER 2000}

\section{SECTION C - TRANSITIONING THE CENTRAL PLATEAU}

Financial / Performance Measures data as of month-end October.

All other data as of November 30, 2000 (unless otherwise noted).

\section{Surveillance/Maintenance \& Transition Project (SM\&T):}

\section{ACCOMPLISHMENTS: SMET}

Survellance and Maintenance: S\&M activities that were performed in October to ensure

inactive facility integrity and safety included the following:

- Completion of various leaking roof repairs at B Reactor.

- Completion of asbestos repairs on B Reactor roof. Significant deterioration in the asbestos insulation on several pipes running across the roof of $B$ Reactor was discovered during vent sealing on the reactor roof. An advance work authorization was approved to proceed with immediate cleanup and temporary abatement of the asbestos pending preparation and approval of a $B C P$.

- Continuation of B Reactor engineering evaluation/cost analysis (EE/CA). Options include no action, S\&M, ISS, and full hazard mitigation for public access.

- Receipt of approval from the Washington State Department of Health on October 17 to remove the 18-meter (60-foot) sample line from the PUREX stack. The sample line shutdown will result in lower maintenance costs by using only the 23-meter (74-foot) sample line.

- Initiation of roof repairs on U Plant (221-U Building). Work consisted of making repairs to three roof sections and performing infrared scanning on all other expansion joint areas to detect any leaking areas that will be repaired in the spring after winter weather subsides.

- Implementation of the Job Hazard Analysis (JHA) process for a several S\&M activities.

- Implementation of freeze protection for all assigned S\&M facilities.

Canyon Disposition Initiative: $A$ total of nine concrete coring samples were obtained from process cells located in U Plant in support of the Canyon Disposition Initiative (CDI). These samples were successfully ground into a slurry for analytical review. Sample contamination and dose rates were low enough that the work was accomplished in the canyon without a glove box.

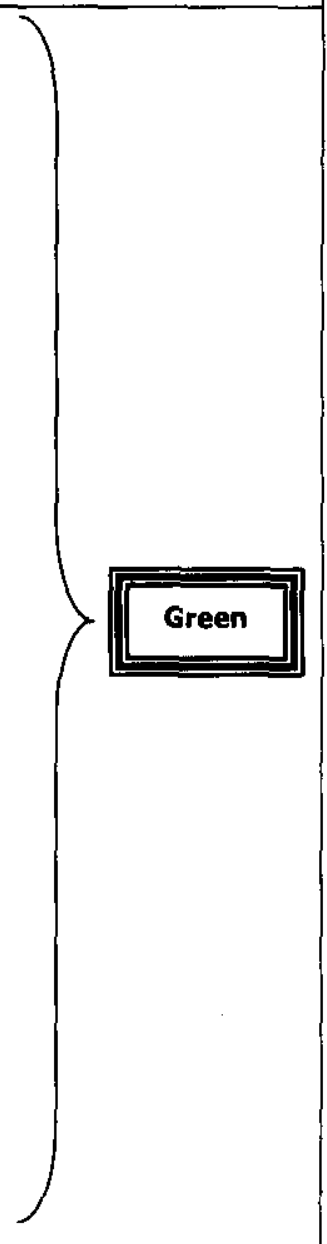




\section{ENVIRONMENTAL MANAGEMENT PERFORMANCE REPORT ENVIRONMENTAL RESTORATION \\ DECEMBER 2000}

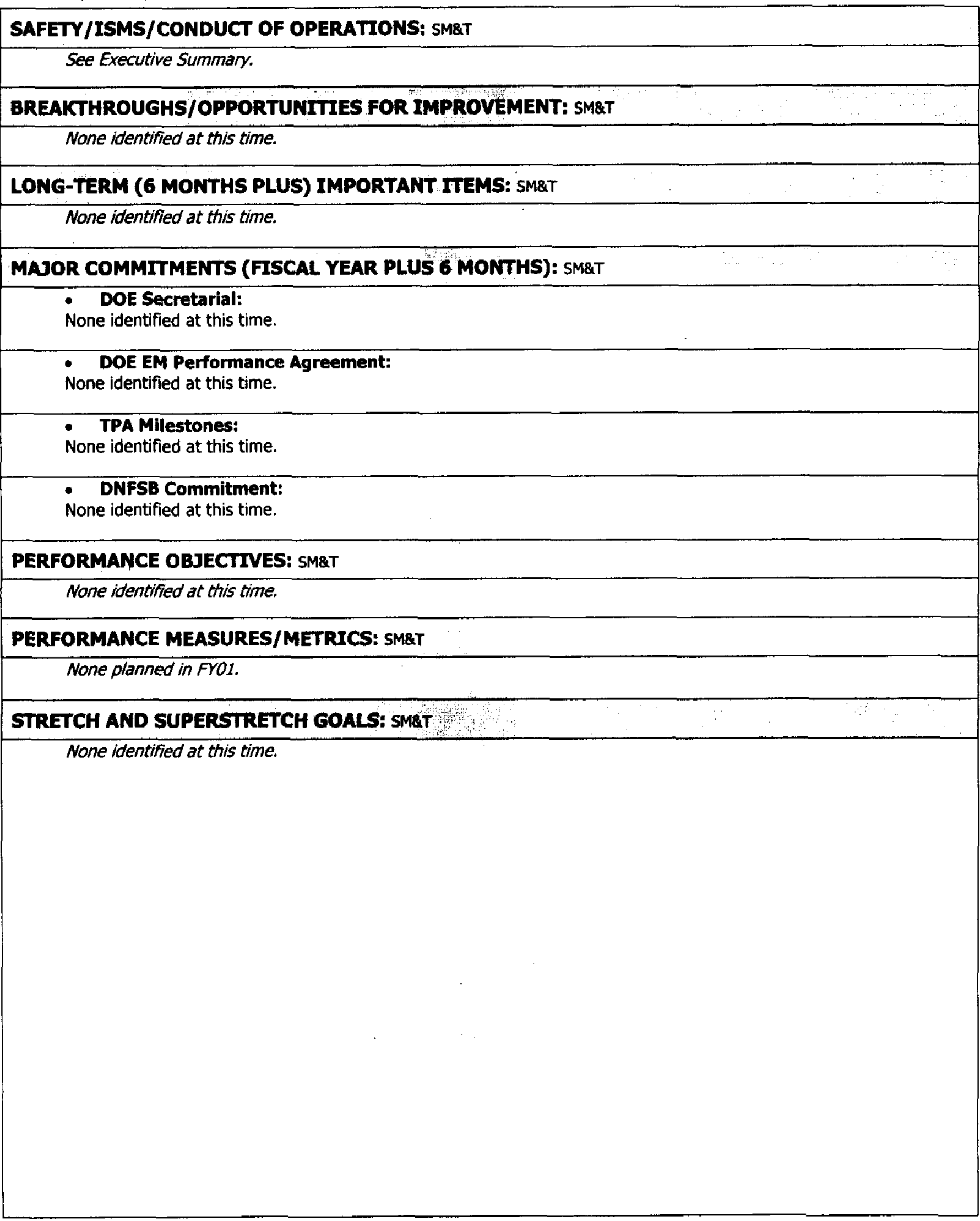




\section{ENVIRONMENTAL MANAGEMENT PERFORMANCE REPORT ENVIRONMENTAL RESTORATION \\ DECEMBER 2000}

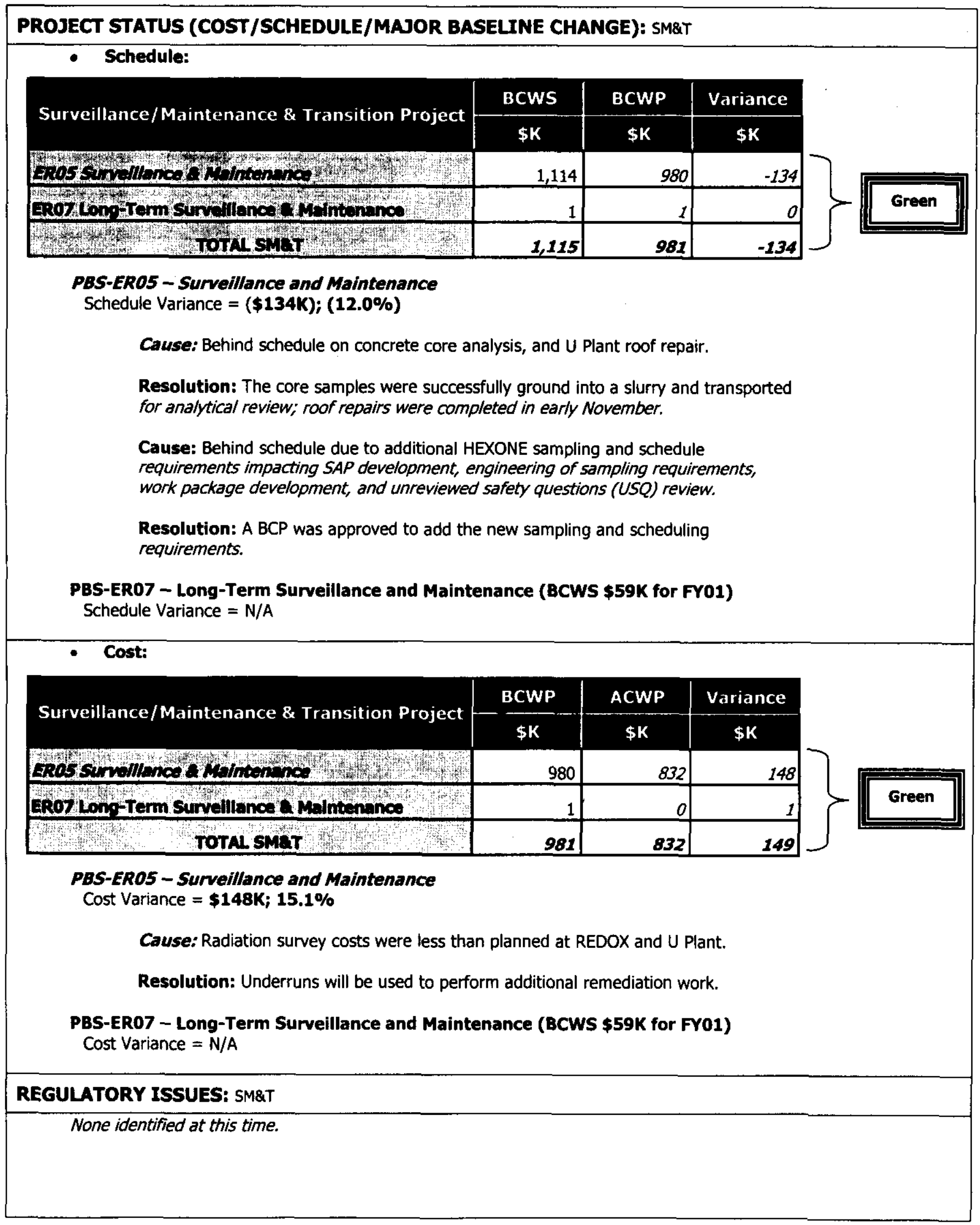


ENVIRONMENTAL MANAGEMENT PERFORMANCE REPORT

ENVIRONMENTAL RESTORATION

DECEMBER 2000

EXTERNAL ISSUES (i.e. HAB, Congress, etc.): SM\&T

None identified at this time.

DOE-RL \& HQ ISSUES/REQUESTS (not covered elsewhere): SM\&T

None identified at this time.

INTEGRATION ACTIVITIES: SM\&T

None identified at this time. 


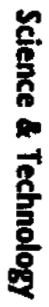




\section{Pacific Northwest National Laboratory Environmental Management Performance Report}

December 2000

PREPARED FOR THE U.S. DEPARTMENT OF ENERGY, RICHLAND OPERATIONS OFFICE OFFICE OF ENVIRONMENTAL MANAGEMENT

Pacific Northwest National Laboratory

Operated for the U.S. Department of Energy

by Battelle Memorial Institute 


\section{Table of Contents}

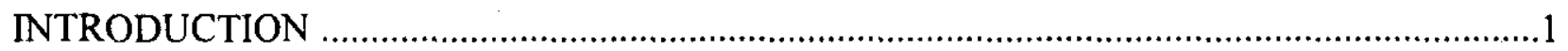

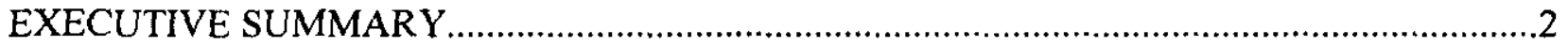

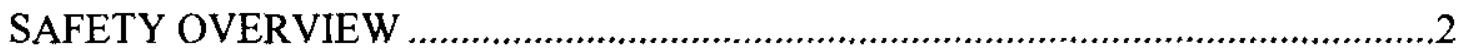

COST/SCHEDULE PERFORMANCE STOPLIGHT .............................................

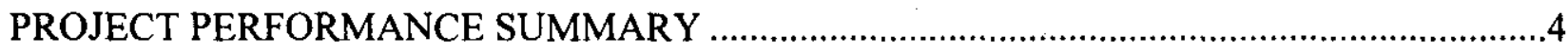

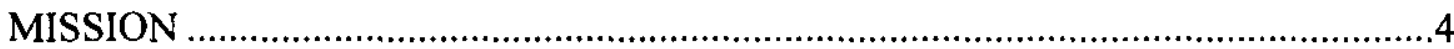

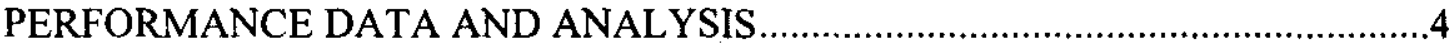


$\mathrm{T}$ his document provides the Department of Energy Richland Operations Office (DOE-RL) with a report of the Pacific Northwest National Laboratory (PNNL) performance by Battelle Memorial Institute and its subcontractors.

In Section A, the Executive Summary, text and graphics report the safety metrics status for all PNNL activities. Senior management's overall performance assessment of all Environmental Management activities conducted at PNNL is presented in a stoplight chart.

Section B, Project Performance Summary, provides a brief summary of the month's performance for the PNNL lead activity, PNNL Waste Management (PBS RL-ST01). More detailed information can be found within PNNL-7911-109a, PNNL's Project Status Report for October 2000. Summary analyses pertaining to PNNL's support to other Project Baseline Summaries (PBSs) are addressed in the contractor's report having lead responsibility for that scope.

Unless otherwise noted, information in this report is current as of October 29, 2000. 
This section provides an executive-level summary of performance information and is intended to bring to management's attention that information considered to be most noteworthy. The section begins with overview of safety, a summary of FY 2001 performance, a summary of Fiscal Year (FY) 2001 Voluntary Protection Program (VPP) activities, followed by a stoplight chart on overall performance.

\section{Safety Overview}

The focus of this section is on documenting trends in work-related injury and illness rates. These are the same performance indicators as appear in the FY2001 Battelle Performance Evaluation and Fee Agreement, which is part of the Pacific Northwest National Laboratory operations Contract. The rates for Recordable and Lost Workday cases are presented graphically in this section and are monitored for statistically significant changes. Current efforts to improve performance are being made through the continued implementation of the Integrated Safety Management System (ISMS), and the development and implementation of the Voluntary Protection Program (VPP).

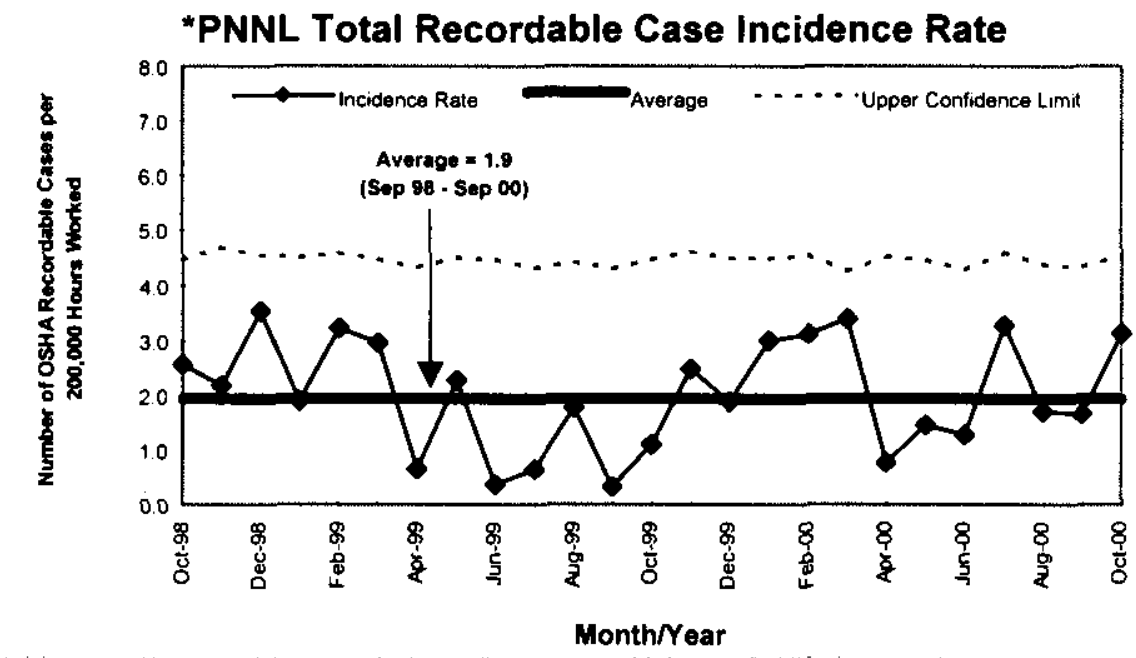

FY 01Rate Overview: Cumulative To Date $=3.14$ Lab Specified Level $\leq 2.2$

This indicator was recently rebaselined over the period of September 1998 - September 2000 after these past 25 months of data were reviewed and found to be stable. The current rates are continuing to randomly fluctuate within the anticipated control limits.

\footnotetext{
*Includes all Pacific Northwest National Laboratory Operations.
} 


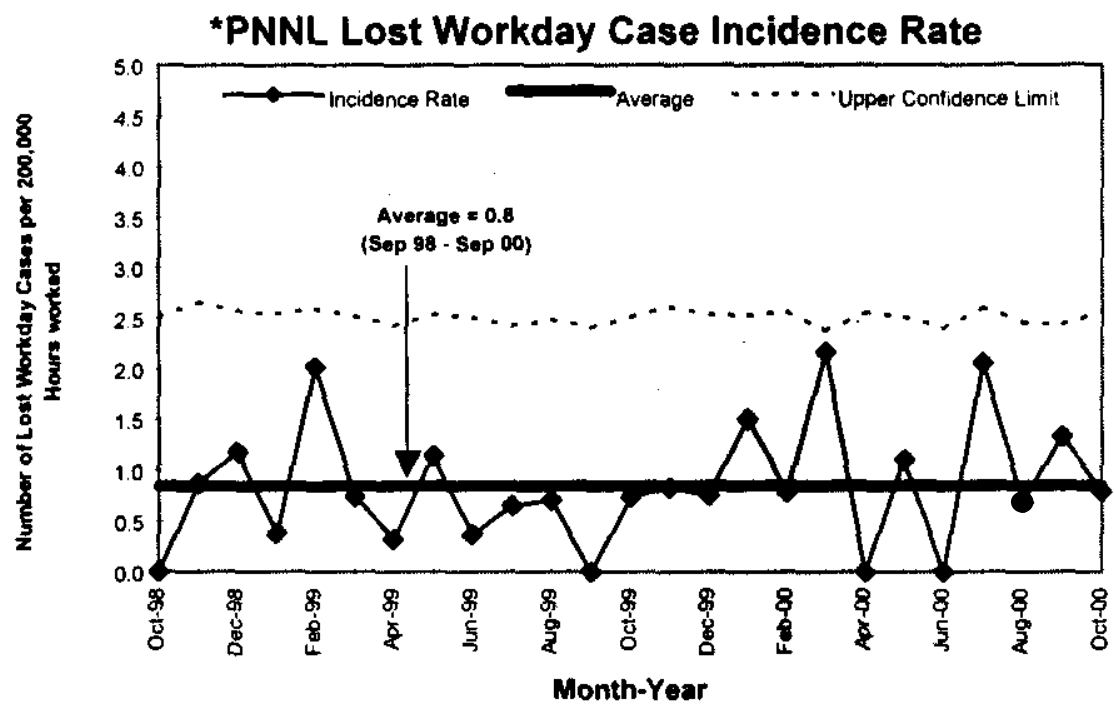

FY 01Rate Overview:

Cumulative To Date $=.78$

Lab Specified Level $\leq 1.1$

This indicator was recently rebaselined over the period of September 1998 - September 2000 after these past 25 months of data were reviewed and found to be stable. The current rates are continuing to randomly fluctuate within the anticipated control limits

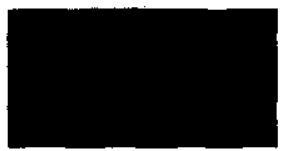

*Includes all Pacific Northwest National Laboratory Operations. "Includes all Pacific National Laboratory Operations.

\section{Cost/Schedule Performance Stoplight}

The following rating reflects overall cost and schedule performance for activities conducted by PNNL. (Narrative not required when rating is green.)

$\begin{array}{ll}\text { Green: } & \text { Satisfactory } \\ \text { Yellow: } & \text { Significant improvement required } \\ \text { Red: } & \text { Unsatisfactory }\end{array}$




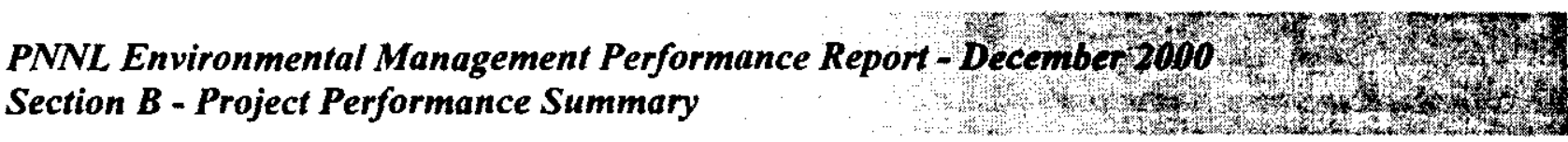

This section provides cost and schedule performance, any significant issues, upcoming baseline 1 change requests for the period covered, and Fiscal Year (FY) 2001 accomplishments. In FY 2001, Battelle Memorial Institute has lead responsibility over PBS RL-ST01, PNNL Waste Management WBS 1.7.1.

\section{Mission}

WBS 1.7.1 provides PNNL with waste management services and compliant operations in support of science and technology development for the multiprogram needs of the U.S. Department of Energy (DOE) Complex. These services include:

- essential surveillance and maintenance of DOE laboratory facilities assigned to PNNL for safe containment of radioactive and hazardous materials

- infrastructure required to manage wastes and effluents currently generated at the PNNL

- operational compliance services to meet regulatory requirements and operating permits including environment, safety, and health regulations

- management of legacy wastes and contamination remaining from past PNNL research operations.

\section{Performance Data and Analysis}

As of October 29,2000 the cumulative costs are $\$ 0.8$ million with a positive cost variance of $\$ 0.03 \mathrm{M}$ and a cumulative schedule variance of negative $\$ 0.2 \mathrm{M}$. The cost variance is within the $10 \%$ reporting threshold. A brief explanation for the variances will be described following the tables and chart.

\begin{tabular}{|l|c|c|c|}
\hline \multicolumn{5}{|c|}{ Cost Performance (\$M): } \\
\hline \multicolumn{5}{|c|}{} & BCWP & ACWP & Variance \\
\hline PNNL Waste Management & $\$ 0.8$ & $\$ 0.8$ & $\$ 0.0$ \\
\hline \multicolumn{5}{|c|}{ Schedule Performance (\$M): } \\
\hline \multicolumn{5}{|c|}{ BCWP } & BCWS & Variance \\
\hline PNNL Waste Management & $\$ 0.8$ & $\$ 1.0$ & $(\$ 0.2)$ \\
\hline
\end{tabular}

FY 2001 Cost/Schedule Performance - All Fund Types

Cumulative to Date Status - (\$000)

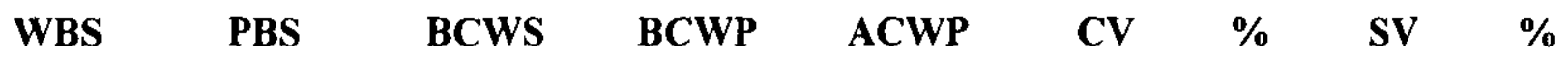

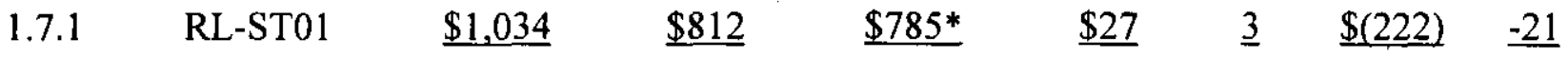

Total $\quad \begin{array}{lllllll}\$ 1,034 & \$ 812 & \$ 785^{*} & \$ 27 & 3 & \$(222) & -21\end{array}$

- Numbers reflect PNNL system; per DISCAS actuals. including $\$$ expended by Fluor for S\&M of 242B/BL, are only $\$ 753.6 \mathrm{~K}$ 
Cost / Schedule Performance Indices

FY 2001 Cum to Date Status (S000s)

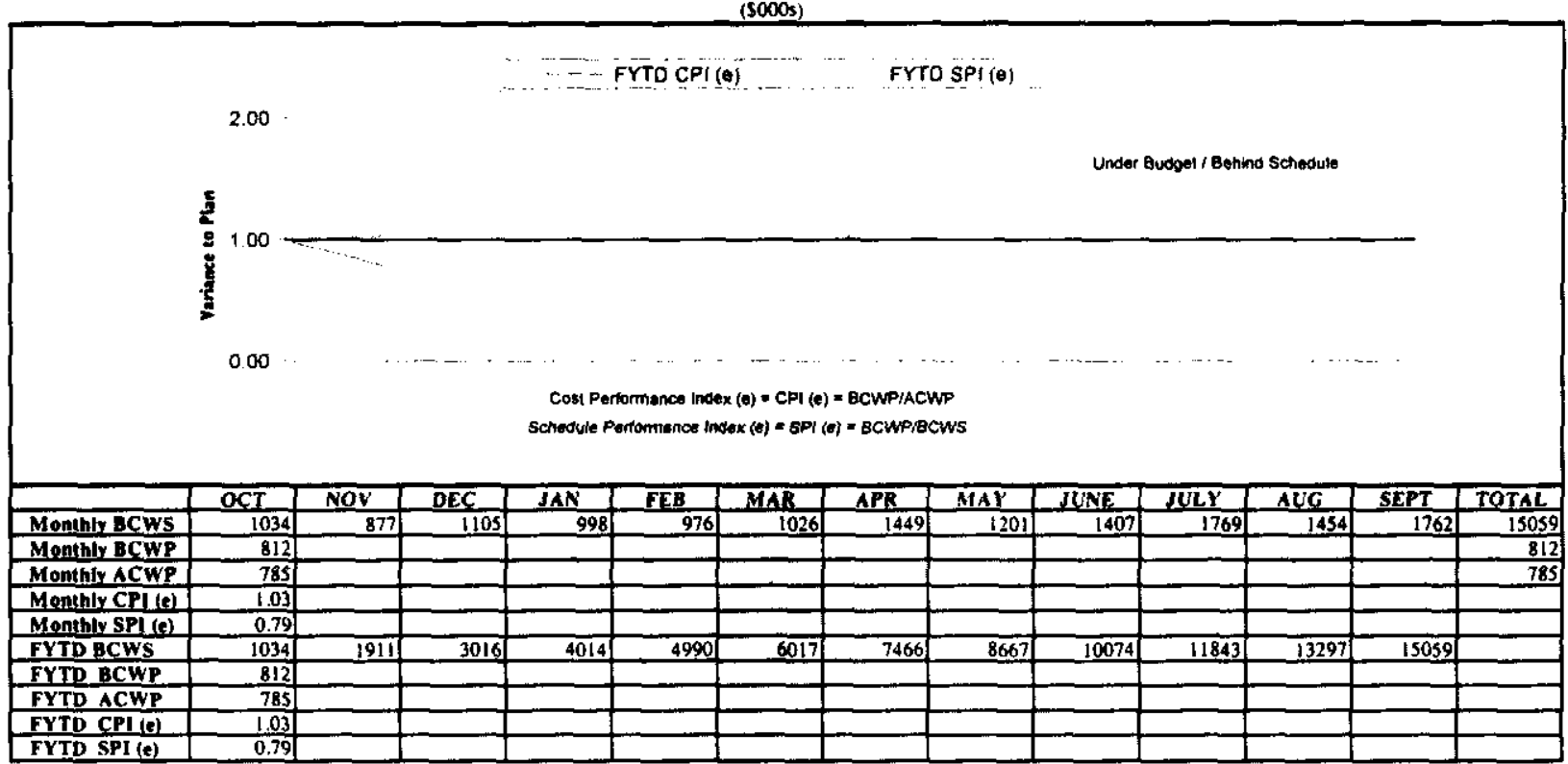

The positive cost variance of $\$ 0.03 \mathrm{M}$ results from delayed billings. This variance will reduce once outstanding costs have been processed. In addition, FY 2001 rates have been finalized and are higher than anticipated during the planning process. The impacts of the cost increase are being assessed.

The schedule variance for October, of negative $\$ 0.2 \mathrm{M}$, is above the $10 \%$ threshold. The primary activities making up the year-end negative schedule variance are as follows:

- Delays have been encountered within the Program awaiting resolution of FY 2001 funding allocations.

- Delays have been encountered with procurement of High Dose Solid Waste shielded drums. As a result of this delay the drum shipping dates for the 73 cans of transuranic (TRU)/low-level waste (LLW) is expected to occur within the first quarter of FY 2001. Concerted efforts are being made to streamline the fabrication process and set priorities for which type of drums need to be available first.

- The integrity assessment of the radioactive liquid waste tank (RLWT)-piping is currently on hold with no defined completion date. The integrity assessment and associated waste processing continues to be delayed because the 204-AR Facility (receiver facility) is not ready, and Pacific Northwest does not want to add any liquids to the tank to make it a radiologically controlled tank until the receiver facility is ready.

Four FY 2000 change requests were approved either deferring or adding scope to FY 2001 baseline using FY 2000 carryover funds. Completion of this scope may be impacted pending resolution of final FY 2001 funding allocations. 


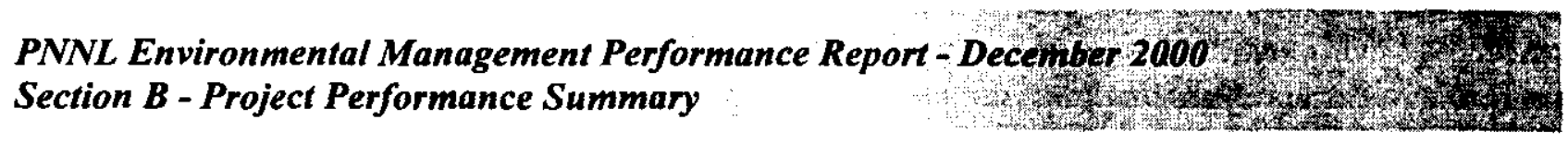

- PWM2000-009, "High Dose Waste and 604 Glovebox Schedule Revisions, RL Milestone Delays," deferred $\$ 139 \mathrm{~K}$ of legacy wasté disposal scope into FY 2000. (Approved $8 / 28 / 00)$

- PWM2000-013, "Adjust Project Baseline to Reflect Basis of Estimate Revision and Deferral of Activities into FY 2001," deferred $\$ 165.3 \mathrm{~K}$ of scope associated with liquid waste disposal using radioactive liquid waste system (RLWS). (Approved 10/2/00)

- PWM2000-014, "Scope Deferral from FY 2000 to FY 2001," deferred \$34.2K of scope to conduct air emissions inventory and air compliance inspections for six Research and Development (R\&D) laboratories into FY 2001. (Approved 10/2/00)

- PWM2000-016, "HVAC Controller Replacement/Upgrade," added \$335K of scope in FY 2001. (Approved 10/2/00) 
$$
\text { 음 }
$$ 


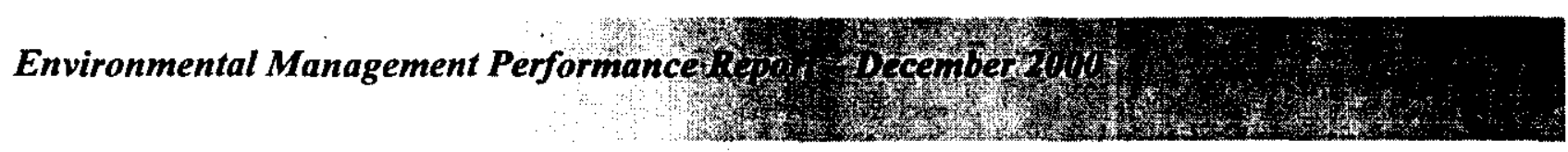

\section{GLOSSARY}

Actual cost of work performed (ACWP): The actual cost incurred and applied or distributed for the work performed within a given time period. It includes all labor categories, material, any other direct costs, subcontract work, and function overhead.

Approved baseline: The budget authorized to perform the workscope that has been agreed upon by the customer and the contractor(s). It is portrayed in the Multi-Year Work Plan with all approved changes. This baseline may or may not be fully funded, and could be more or less than the compliance baseline.

Budget at completion (BAC): The sum of budgets established to complete a program and/or project or any component of a program and/or project.

Budgeted cost of work performed (BCWP): The value for completed work measured in terms of the planned budget for that work. It is synonymous with earned value.

Budgeted cost of work scheduled (BCWS): The time-phased budgeted value of work scheduled to be accomplished over a given time period. The BCWS for a total cost account through its entire period of performance is equal to the BAC for the cost account.

Carryover Workscope: The estimated dollar amount of the workscope that was not completed during the fiscal year and which will be carried over and completed in the next fiscal year.

Compliance baseline: The budget that is required to perform the workscope necessary to be in compliance with State and Federal regulations, enforceable agreement milestones, and DNFSB milestones. The level of activity required to be in compliance assumes sufficient funding. Note: Because approved baselines are considered to be compliant, this column will likely be eliminated.

Contract Inherited: The assumed budget for the planned scope of work at the time a new contract is signed by the company responsible for performing the work.

Cost variance (CV): The difference between BCWP and ACWP (CV = BCWP - ACWP). At any time, it shows whether the work actually performed has cost more or less than the amount budgeted for the same work.

Cost Performance Indicator (CPI): The CPI is the ratio of BCWP to ACWP, or (BCWP/ACWP).

Earned value (EV): The periodic, consistent, and objective measurement of work performed in terms of the budget planned for that work. The EV is synonymous with the BCWP and it is compared to the BCWS to obtain schedule performance and to the ACWP to obtain cost performance. 


\section{GLOSSARY (CONTINUED)}

Estimate at completion (EAC): Cost allocated to the work breakdown structure element to date, plus the estimate of costs for authorized work remaining. Authorized work remaining includes any undistributed budget.

Fiscal Year Spending Forecast (FYSF): The estimated total that will be spent from October through September (current Fiscal Year).

Funding carryover and new Budget Authorization (BA): This funding represents both the funding allocated to perform workscope planned in the prior fiscal year, not completed, and approved to be performed in the current fiscal year, as well as new BA to perform the approved baseline workscope.

Funding target: The level of funding that is anticipated (as a result of the Integrated Priority List process) in a given Fiscal Year based on an assumed funding level for the Site.

Multi-Year Work Plan - 10/1/XX: The Project's approved cost/schedule/technical baseline at the beginning of the fiscal year.

Project Execution Module (PEM): The Project Execution Module (PEM) of the Integrated Planning, Accountability, and Budgeting System-Information System (IPABS-IS) replaces the Progress Tracking System (PTS) as EM Headquarters' centralized system for reporting financial, milestone, performance, and other execution-year information for PBSs, sub-PBSs, TTPs, and line item construction projects. In addition, this module collects mid-year and year-end actual performance information against the agreed upon management commitments for the current execution year.

Schedule Performance Indicator (SPI): The SPI is the ratio of BCWP to BCWS, or (BCWP/BCWS).

Schedule variance (SV): The difference between BCWP and BCWS (SV = BCWP - BCWS). At any time, or for a given period of time, it represents the difference between the planned dollar value of work actually accomplished and the value of the work scheduled to be accomplished.

Work breakdown structure (WBS): A product-oriented family tree division of real estate, hardware, software, services, and data products that organize, define, and display all of the work to be performed in accomplishing the program and/or project objectives. 